\title{
Geologic Map of the Beacon Rock Quadrangle, Skamania County, Washington
}

By Russell C. Evarts and Robert J. Fleck

Pamphlet to accompany

Scientific Investigations Map 3367

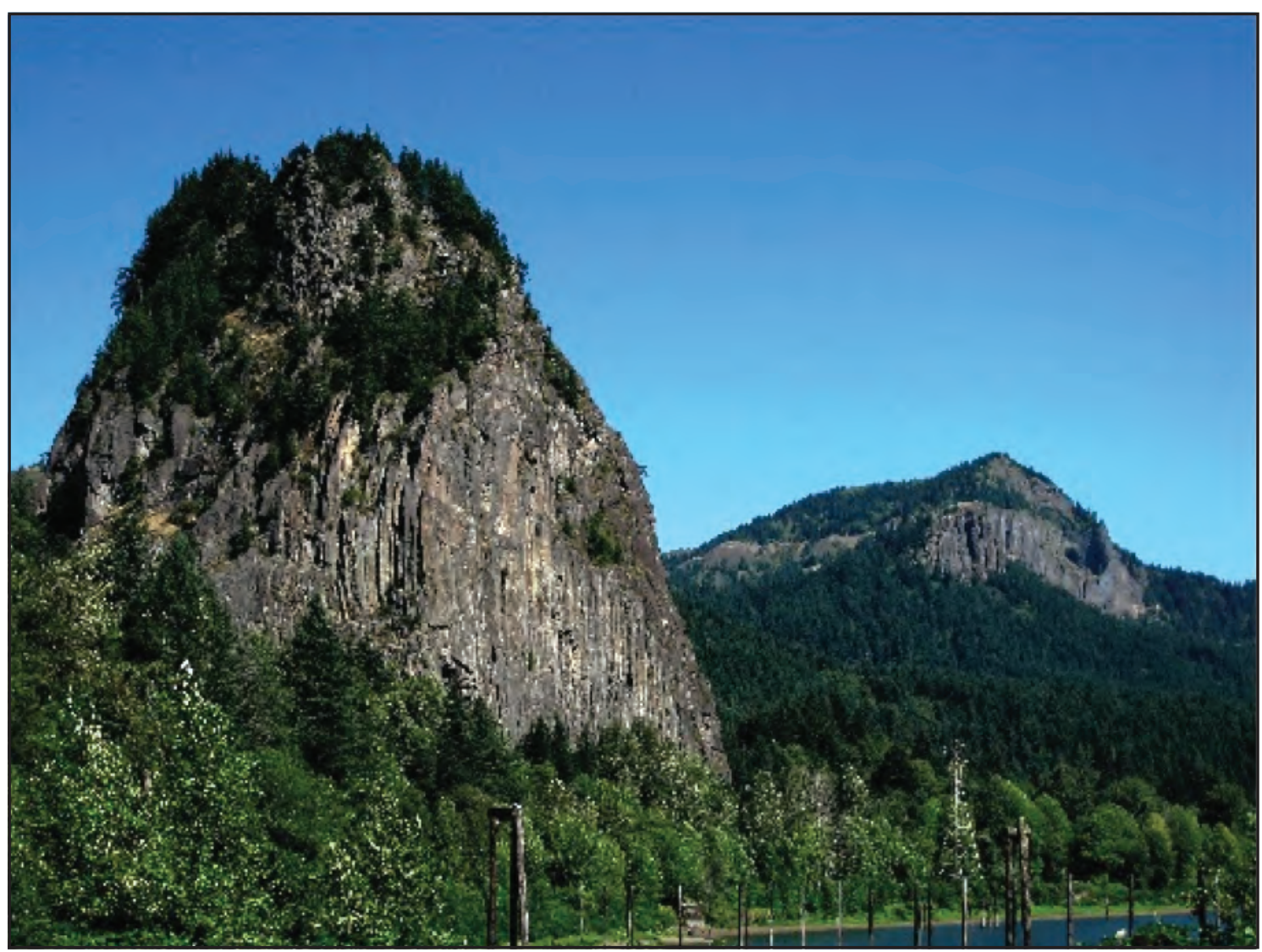

Beacon Rock along north shore of Columbia River, Hamilton Mountain in background.

2017

U.S. Department of the Interior

U.S. Geological Survey 



\section{Contents}

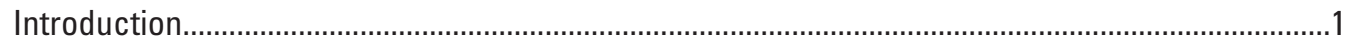

Geographic and Geologic Setting .......................................................................................

Previous Geologic Investigations in the Western Columbia River Gorge ..................................1

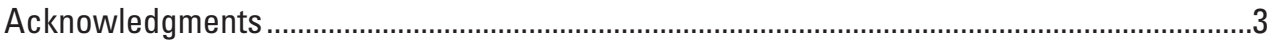

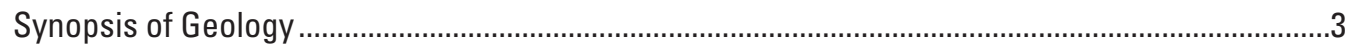

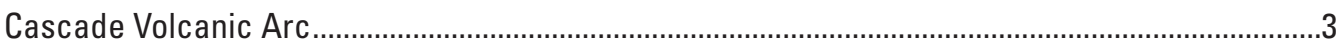

Stratigraphic Relations and Nomenclature............................................................................

Oligocene and Early Miocene Strata Older than the Lava Flows of Hamilton Creek................5

Lava Flows of Hamilton Creek ..............................................................................................

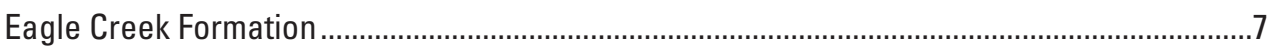

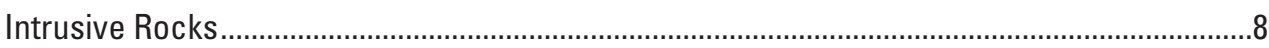

Metamorphism and Hydrothermal Alteration ......................................................................

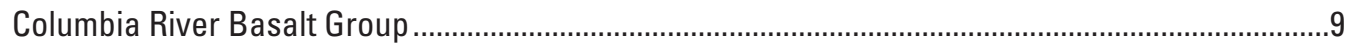

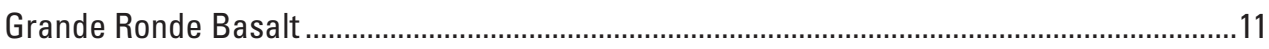

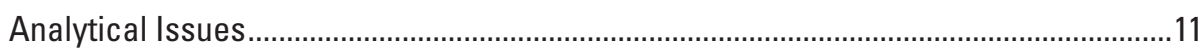

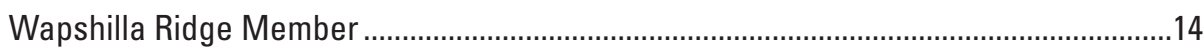

Grouse Creek Member................................................................................................14

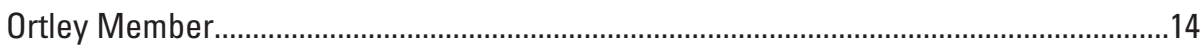

Winter Water Member ……......................................................................................

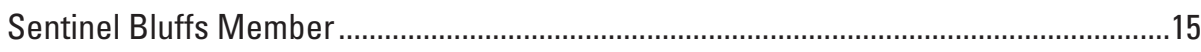

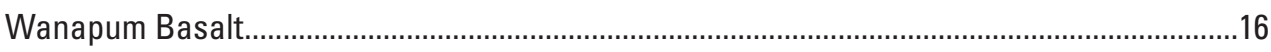

Frenchman Springs Member ……........................................................................

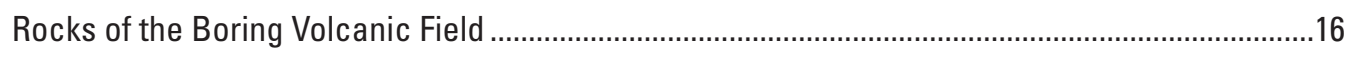

Alluvial and Mass-Wastage Deposits ...................................................................................18

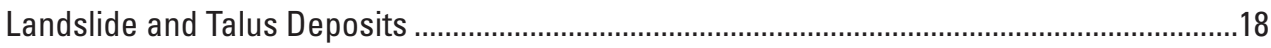

Holocene and Pleistocene Alluvium of Tributary Streams ...................................................19

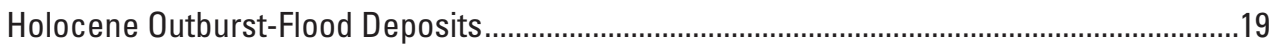

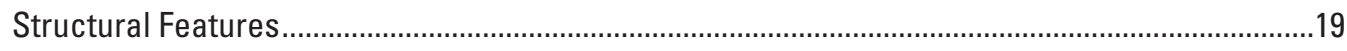

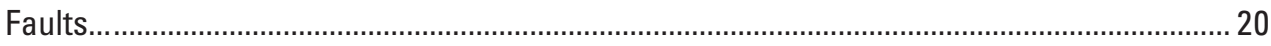

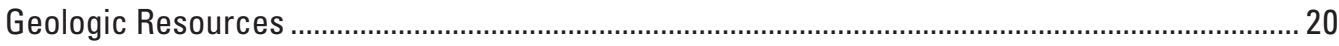

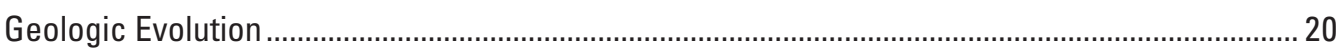

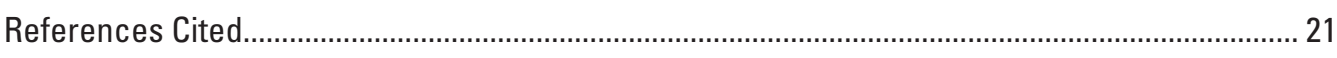

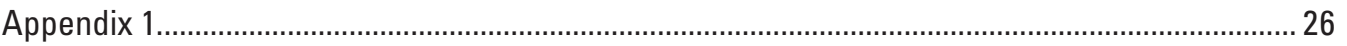

\section{Figures}

1. Regional setting of Beacon Rock 7.5' quadrangle.

2. Simplified geology of Beacon Rock quadrangle showing distribution of rocks of ancestral Cascade volcanic arc, Columbia River Basalt Group, and Quaternary volcanic rocks

3. Chemical characteristics of volcanic rocks from Beacon Rock 7.5' quadrangle

(analyses recalculated volatile-free) ............................................................................

4. Cliff composed of upper Eagle Creek Formation on southeast flank of Hamilton

Mountain .................................................................................................................

5. Plot of $\mathrm{Sr} / \mathrm{Y}$ versus $\mathrm{Y}$ for igneous rocks in Beacon Rock 7.5' quadrangle ..........................8

6. Typical jointing patterns exhibited by lava flows of the Columbia River Basalt Group.....10 
7. Stratigraphic nomenclature, ages, and magnetic polarities of the Columbia River Basalt Group

8. Chemical characteristics of Grande Ronde Basalt flows in the Beacon Rock 7.5' quadrangle

9. Paleomagnetic directions for Grande Ronde Basalt flows in the Beacon Rock $7.5^{\prime}$ quadrangle

10. South face of Hamilton Mountain showing 200-m-thick intracanyon Grande Ronde Basalt flow overlying basal foreset-bedded pillow breccia of same flow on the left and Eagle Creek Formation on the right

11. Selected chemical characteristics of Pleistocene volcanic and subvolcanic rocks in the Beacon Rock 7.5' quadrangle

12. Paleomagnetic directions for Quaternary volcanic rocks in the Beacon Rock 7.5' quadrangle

13. Three Corner Rock, a mass of basaltic andesite that occupied the throat of a now-eroded, approximately 1-Ma scoria cone

\section{Tables}

1. Chemical and modal analyses of igneous rocks of the ancestral Cascade volcanic arc, Beacon Rock 7.5' quadrangle, Skamania County, Washington

2. Chemical analyses of the Columbia River Basalt Group, Beacon Rock 7.5' quadrangle, Skamania County, Washington

3. Chemical and modal analyses of Quaternary volcanic rocks, Beacon Rock 7.5' quadrangle, Skamania County, Washington.

4. Summary of ${ }^{40} \mathrm{Ar} /{ }^{39} \mathrm{Ar}$ incremental-heating age determinations, Beacon Rock 7.5' quadrangle, Skamania County, Washington

5. Paleomagnetic data for Columbia River Basalt flows and Quaternary volcanic rocks, Beacon Rock 7.5' quadrangle, Skamania County, Washington 


\section{Introduction}

\section{Geographic and Geologic Setting}

The Beacon Rock 7.5' quadrangle is located approximately $50 \mathrm{~km}$ east of Portland, Oregon (fig. 1), on the north side of the Columbia River Gorge, a scenic canyon carved through the axis of the Cascade Range by the Columbia River. Although approximately 75,000 people live within the gorge, much of the region remains little developed and is encompassed by the 292,500-acre Columbia River Gorge National Scenic Area, managed by a consortium of government agencies "to protect and provide for the enhancement of the scenic, cultural, recreational and natural resources of the Gorge and to protect and support the economy of the Columbia River Gorge area." As the only low-elevation corridor through the Cascade Range, the gorge is a critical regional transportation and utilities corridor (Wang and Chaker, 2004). Major state and national highways and rail lines run along both shores of the Columbia River, which also provides important water access to ports in the agricultural interior of the Pacific Northwest. Transmission lines carry power from hydroelectric facilities in the gorge and farther east to the growing urban areas of western Oregon and Washington, and natural-gas pipelines transect the corridor (Wang and Chaker, 2004). These lifelines are highly vulnerable to disruption by earthquakes, landslides, and floods. A major purpose of the work described here is to identify and map geologic hazards, such as faults and landslide-prone areas, to provide more accurate assessments of the risks associated with these features.

The steep canyon walls of the map area reveal extensive outcrops of Miocene flood-basalt flows of the Columbia River Basalt Group capped by fluvial deposits of the ancestral Columbia River, Pliocene lavas erupted from the axis of the Cascade arc to the east, and volcanic rocks erupted from numerous local vents. The Columbia River Basalt Group unconformably rests on a sequence of late Oligocene and early Miocene rocks of the ancestral Cascade volcanic arc, which underlies most of the map area. The resistant flood-basalt flows form some of the famous landforms in the map area, such as Hamilton Mountain. Extensive landslide complexes have developed where the basalt flows were emplaced on weak volcaniclastic rocks.

\section{Previous Geologic Investigations in the Western Columbia River Gorge}

The spectacular exposures in the Columbia River Gorge have attracted the attention of geologists for well over a century. Although observations and interpretations regarding specific aspects of gorge geology go back as far as the Lewis and Clark expedition of 1804-1807, the first comprehensive description of geologic relations in the Columbia River Gorge was by Ira S. Williams (1916). His popular account was published as a beautifully illustrated geologic road guide shortly after completion of the Columbia River Scenic Highway in Oregon. The report and accompanying map were the first to describe the major stratigraphic units visible in the walls of the gorge. He distinguished four major rock units: tuff and conglomerate that he named the Eagle Creek Formation, Miocene Columbia River basalt, cobbly gravels assigned to the Satsop Formation, and young andesitic and basaltic lavas and tuffs, which he called the Cascades Formation. All except the post-basalt gravels are present in the Beacon Rock area. Despite marked changes in geologic concepts and terminology in the past century, later workers have largely retained the basic stratigraphic framework outlined by Williams.

Hodge (1938) published a wide-ranging synthesis of more than a decade of work by him and his students in the Columbia River Gorge. Lacking adequate age constraints or chemical data to distinguish lavas of varying age, many of his concepts regarding the stratigraphy, structure, and geologic history have proved to be incorrect. Most subsequent studies (Chaney, 1959; Lowry and Baldwin, 1952; Trimble, 1963; Wise, 1970; Waters, 1973; Swanson and others, 1979a; Hammond, 1980; Tolan, 1982; Hammond and Korosec, 1983; Tolan and Beeson, 1984; Fleck and others, 2014) have been restricted to limited areas or have emphasized specific aspects of gorge geology. Wise (1970) mapped the area directly east of the Beacon Rock quadrangle and showed that the Eagle Creek Formation of Williams (1916) consists of two lithologically distinct volcanogenic units of the western Columbia River Gorge and discussed causes of the extensive landslides found north of the Columbia River. Swanson and others (1979b) established a formal stratigraphic nomenclature for the Columbia River Basalt Group and applied it to exposures in Washington. These revisions were incorporated into the reconnaissance geologic map of the southern Washington Cascade Range by Hammond (1980), who also broke out lithologic packages within the sub-basalt rocks of the ancestral Cascade volcanic arc, mapped the Plio-Pleistocene volcanic rocks, and inferred several major structures. Hammond and Korosec (1983) provided chemical analyses and a few K-Ar ages for some of the young volcanics.

The most recent geologic map that includes the Beacon Rock quadrangle is Phillips' (1987) compilation of the Vancouver $30^{\prime}$ x $60^{\prime}$ quadrangle at 1:100,000 scale, which was prepared as part of the state geologic mapping program of the Washington Division of Geology and Earth Resources (Walsh and others, 1987). The geology of the Columbia River Gorge area portrayed on this map is taken without modification from the small-scale regional reconnaissance maps of Swanson and others (1979a) and Hammond (1980).

Allen (1975) briefly discussed Quaternary volcanoes (Boring lavas) of the greater Portland region. Palmer (1977) summarized information on the huge landslides along the north bank of the Columbia River, and Pierson and others (2016) mapped landslides in the western Columbia River Gorge based largely on interpretation of digital elevation models derived from lidar data.

Our new work expands upon these previous efforts in several ways. It shows lithologic variations and structures within strata of the ancestral Cascade volcanic arc and provides extensive chemical analyses and ${ }^{40} \mathrm{Ar} /{ }^{39} \mathrm{Ar}$ incremental-heating 

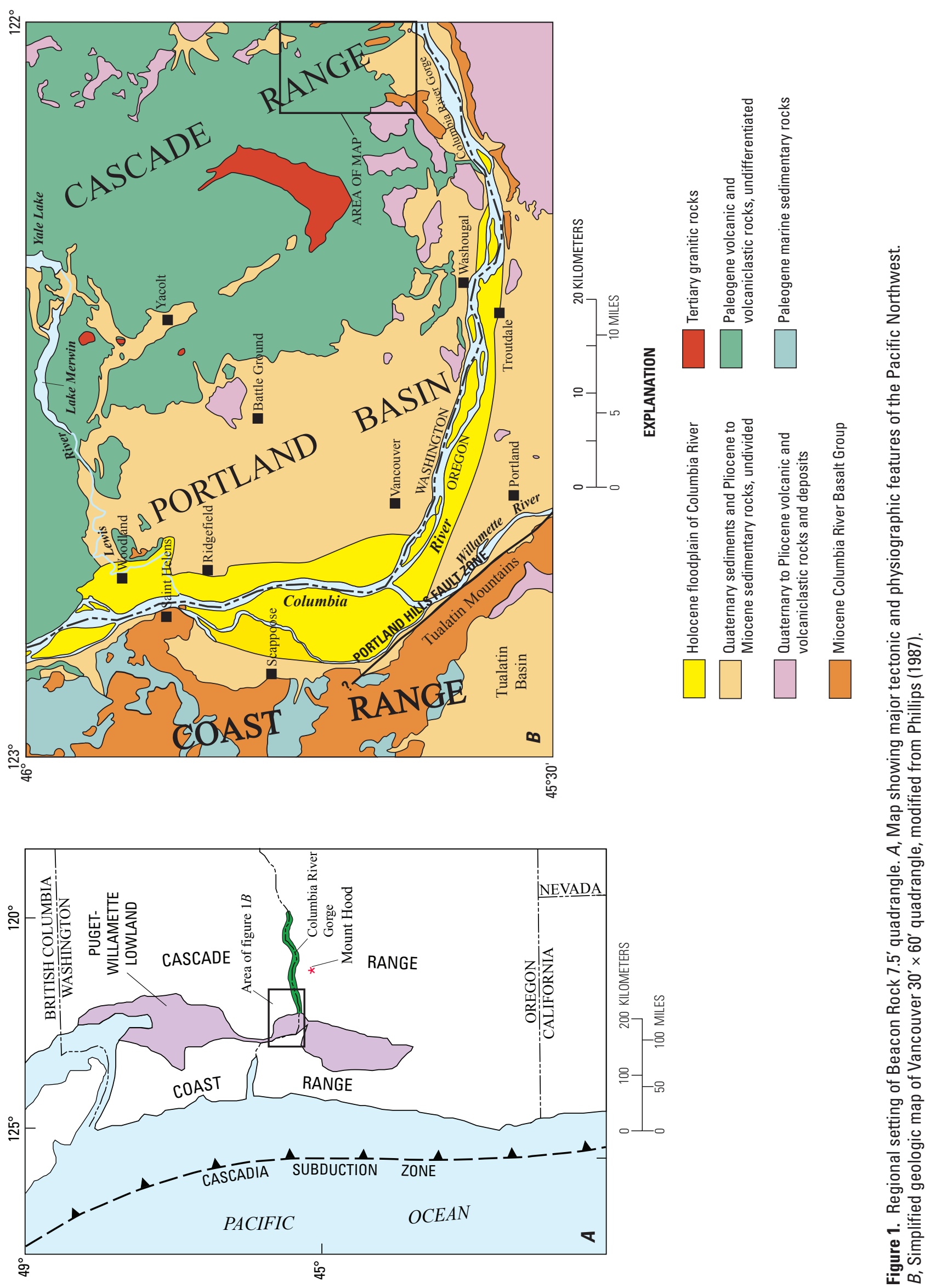

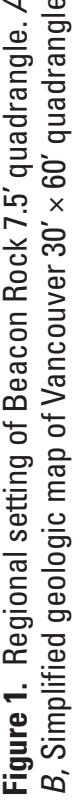


ages for these rocks. A more detailed stratigraphy for Grande Ronde Basalt, founded on abundant new chemical and paleomagnetic data, is presented. Similarly, the young volcanic rocks previously mapped as the Boring Lavas are differentiated based on their chemical and paleomagnetic properties, radiometric age determinations, and inferred source vents. The new chemical analyses are provided in tables $1-3,{ }^{40} \mathrm{Ar} /{ }^{39} \mathrm{Ar}$ determinations in table 4 , and paleomagnetic data in table 5 .

\section{Acknowledgments}

Landowners and land-management agencies granted access that was essential for detailed mapping in the Beacon Rock quadrangle. We particularly thank Brian Poehlein of the Washington Department of Natural Resources; Erik Plunkett, supervisor of Beacon Rock State Park; and Denny Mohan of Longview Fibre Company. Philip A. Dinterman assisted with fieldwork in 2002. A lidar survey covering the map area, kindly provided by Stephanie Zurenko and Terry Curtis of the Washington Department of Natural Resources, was used by Karen Wheeler and Zenon Valin at the U.S. Geological Survey (USGS) to generate field sheets and the base map. Diane M. Johnson-Cornelius and Richard M. Conrey of Washington State University produced the high-quality chemical analyses required to differentiate Columbia River Basalt Group flows, and our USGS colleague Jonathan T. Hagstrum provided high-quality paleomagnetic data. Kenneth Bishop and Judith Fierstein of the USGS made available essential laboratory facilities. We obtained water-well drillers' logs from the Washington Department of Ecology website at https://fortress.wa.gov/ecy/ waterresources/map/WCLSWebMap/default.aspx. Lee Walkling aided in obtaining information from the Washington Division of Geology and Earth Resources Library in Olympia, Washington. We have benefited immensely from discussions on various aspects of the regional stratigraphy, structure, and geologic history with Roger Ashley, Richard Conrey, Trevor Contreras, Paul Hammond, Jim O’Connor, William Phillips, Patrick Pringle, Stephen Reidel, Michael Sawlan, David Sherrod, James Smith, Terry Tolan, Richard Waitt, and Ray Wells. O'Connor provided descriptions of some Quaternary deposits along the Columbia River. We appreciate the careful reviews by Ralph Haugerud and Paul Stone that resulted in significant improvements in the content and presentation of this map.

\section{Synopsis of Geology}

For the past 40 m.y., the Cascade Range has been the locus of an episodically active volcanic arc associated with underthrusting of oceanic lithosphere beneath the North American continent along the Cascadia Subduction Zone. Late Oligocene to early Miocene rocks of the ancestral Cascade volcanic arc underlie most of the Beacon Rock quadrangle and comprise three unconformity-bounded stratigraphic packages (fig. 2). The lower part of the stratigraphic section in the map area consists of diverse, moderately altered, volcaniclastic rocks and lesser lava flows of late Oligocene to early Miocene age. An angular unconformity separates these rocks from an overlying and less-altered sequence of early Miocene porphyritic andesite and basaltic andesite flows, herein informally named the lava flows of Hamilton Creek. The top of this unit, locally marked by a thick paleosol, is an unconformable contact with weakly lithified volcaniclastic deposits of the early Miocene Eagle Creek Formation. Arc volcanism in southern Washington waned after the early Miocene.

In the middle Miocene, huge volumes of basaltic lava, the Columbia River Basalt Group, erupted from fissure vents in Idaho and eastern Washington and Oregon. Between $16 \mathrm{Ma}$ and $12 \mathrm{Ma}$, several of these flood-basalt flows crossed the Cascade Range through a broad lowland and entered western Oregon and Washington. In the Beacon Rock quadrangle, these flows, mostly Grande Ronde Basalt, are banked against the eroded top of the Eagle Creek Formation and mark the north margin of the Miocene trans-arc valley.

Following cessation of flood-basalt eruptions, the ancestral Columbia River incised a canyon located south of the map area. During the late Pliocene, voluminous volcanic activity related to a northward-propagating intra-arc rift filled this paleocanyon, forcing the river northward to its present position. Young volcanism in southern Washington has been more dispersed and less vigorous than that to the south. Several small extinct volcanoes have been mapped in the Beacon Rock quadrangle; they are the northeasternmost centers of the Pliocene to Quaternary Boring Volcanic Field (Treasher, 1942; Trimble, 1963; Allen, 1975; Evarts and others, 2009).

In the latest Pleistocene, cataclysmic outburst floods poured through the Columbia River Gorge. Their effects in the gorge were primarily erosive and they left only sparse thin deposits in the map area, although they undercut canyon walls and may have triggered some of the large landslides along the Columbia River.

Deformation in the area is characterized by mild folding, with attitudes in the older beds generally striking northeast to north-northeast and dipping moderately $\left(15-30^{\circ}\right)$ southeast. Decreasing dips in progressively younger strata indicate that folding occurred gradually throughout the Miocene, but deformation of the 16-Ma Grande Ronde Basalt Group is limited to gentle tilting $\left(2^{\circ}\right)$ to the southwest. Only a few small faults have been mapped; none are known to have moved during the Quaternary.

\section{Cascade Volcanic Arc}

\section{Stratigraphic Relations and Nomenclature}

Williams (1916) applied the name Eagle Creek Conglomerate to volcaniclastic rocks that underlie Columbia River Basalt flows in the Columbia River Gorge. The unit was renamed the Eagle Creek Formation by Chaney (1918), who, in subsequent publications, described its fossil flora in detail and eventually assigned it an early Miocene age (Chaney, 1944, 1959). Wise $(1961,1970)$ and Waters (1973) recognized that the volcanic-arc strata in the area directly east of the Beacon Rock 


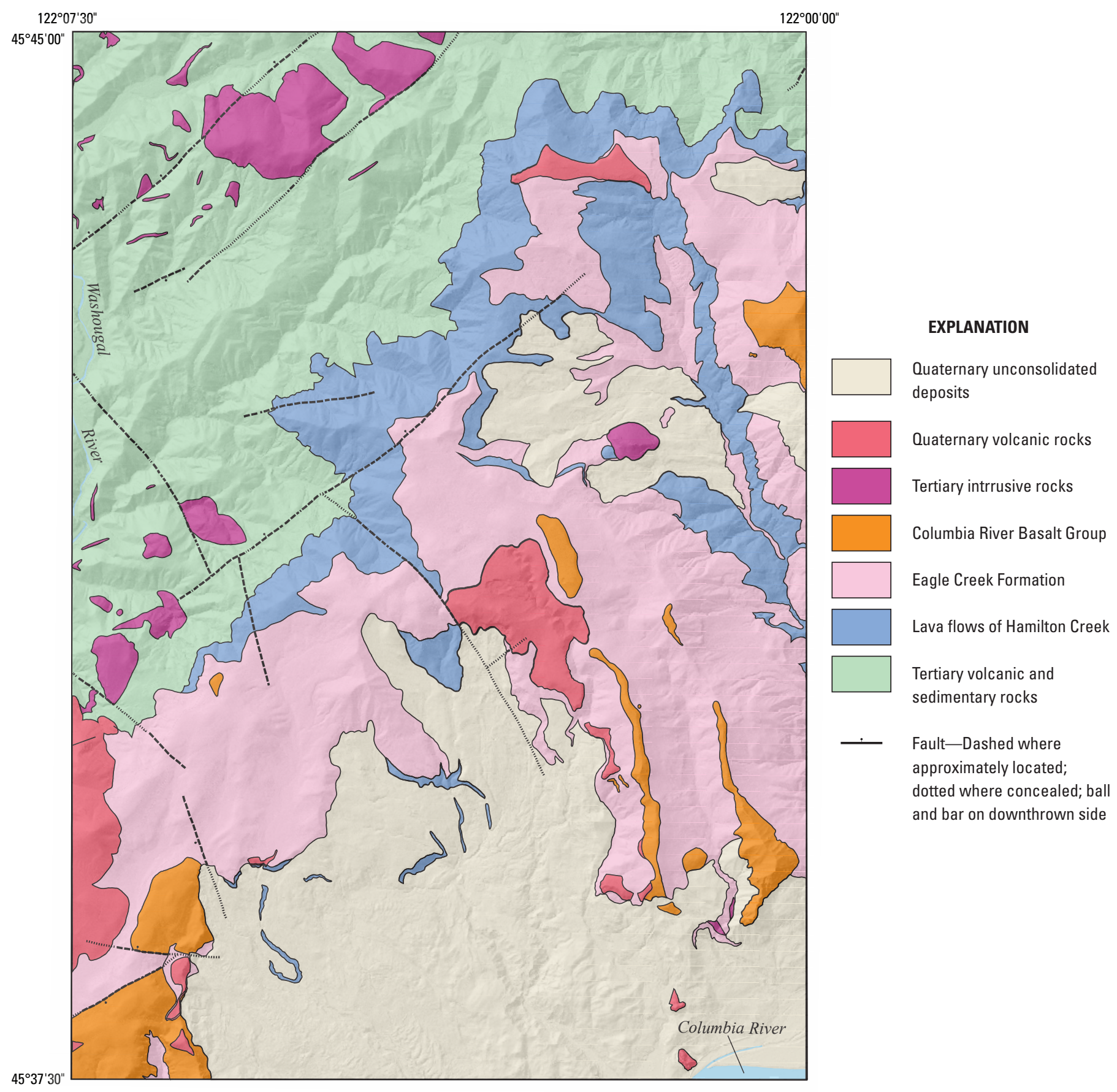

Figure 2. Simplified geology of Beacon Rock quadrangle showing distribution of rocks of ancestral Cascade volcanic arc, Columbia River Basalt Group, and Quaternary volcanic rocks.

quadrangle consisted of two dominantly volcaniclastic but lithologically distinct units separated by an erosional unconformity. Wise (1970) therefore redefined the Eagle Creek Formation as "the sequence of volcanic conglomerates, sandstones, and tuffs that are typically exposed south of the Columbia River along Eagle Creek." This definition restricted the name Eagle Creek to those rocks above the unconformity, which included all of the fossiliferous beds studied by Chaney (1944). Wise (1970) assigned the more altered and deformed strata below the unconformity to the Ohanapecosh Formation, which has its type area in Mount Rainier National Park, more than $100 \mathrm{~km}$ north of the map area.
Hammond (1980) traced the unconformity at the base of the Eagle Creek Formation westward into the Beacon Rock quadrangle, where the stratigraphic section contains numerous lava flows and is more heterogeneous than to the east. He divided the folded and altered strata beneath the unconformity into three units, from oldest to youngest: the Ohanapecosh Formation, the Stevens Ridge Formation, and the informal lava flows of Three Corner Rock. Although the stratigraphic relations shown by Hammond (1980) are broadly correct, the nomenclature he employed is not adopted here. Correlation of the Oligocene and earliest Miocene rocks in the Beacon Rock quadrangle with the Ohanapecosh (chiefly volcaniclastic 
sedimentary rocks) and Stevens Ridge (chiefly pyroclastic rocks) Formations in their type areas at Mount Rainier National Park is questionable. This correlation was based largely on gross lithologic similarity, but subsequent regional mapping (Evarts and Swanson, 1994) and age determinations (Vance and others, 1987) demonstrate that the strata in the two widely separated areas are neither coeval nor laterally contiguous. Furthermore, broadly equivalent strata elsewhere in southern Washington have been given other names (Wilkinson and others, 1946; Roberts, 1958; Hammond, 1980; Phillips, 1987), and no reliable criteria have been found for mapping contacts between these various units. For these reasons, we employ strictly lithologic names or, where appropriate, informal lithostratigraphic names in reference to the strata that Hammond (1980) mapped as Ohanapecosh and Stevens Ridge Formations.

The upper part of the pre-Eagle Creek section in the map area consists almost entirely of porphyritic lava flows, which Hammond (1980) informally named lava flows of Three Corner Rock. The detailed mapping presented here confirms the existence of these flows and shows that the basal contact of this flow-dominated unit is an unconformity. However, because Three Corner Rock is a Pleistocene volcanic plug (see Rocks of the Boring Volcanic Field section), we rename these Tertiary rocks the (informal) lava flows of Hamilton Creek.

\section{Oligocene and Early Miocene Strata Older than the Lava Flows of Hamilton Creek}

Lithologically diverse, northeast-striking and southeastdipping strata that predate the lava flows of Hamilton Creek underlie much of the Washougal River drainage basin in the northwestern part of the map area. As much as 2,500 m of these rocks are exposed in the map area and comprise a lower volcaniclastic section, a middle section dominated by lava flows and ignimbrites, and an upper volcaniclastic section.

Volcaniclastic sedimentary rocks (Tvs) with rare small lava flows form the stratigraphically lowest part of this sequence in the map area. Thin- to medium-bedded, fine- to coarse-grained fluvial deposits predominate and are well exposed in the beds of the Washougal River and its tributaries, Prospector, Deer, and Timber Creeks. Thick, massive, pumiceous lapilli tuffs, probably deposited by pyroclastic flows, are subordinate but abundant locally, as along the Washougal River near the mouth of Stebbins Creek.

The lower volcaniclastic-dominated section is conformably overlain by a section composed of basaltic andesite (Tba), lesser andesite and dacite $(\mathrm{Ta}, \mathrm{Td})$, rare basalt $(\mathrm{Tb}, \mathrm{Tob})$, and lapilli tuff and tuff breccia (Tt, Tts). This flow-dominated section is best exposed in Stebbins Creek. Most of the flows are aphyric to sparsely phyric $(<10-12$ percent phenocrysts, although a coarsely porphyritic basaltic andesite at the base of this section holds up the ridgecrest between Timber Creek and Stebbins Creek; plagioclase from this flow gave an ${ }^{40} \mathrm{Ar} /{ }^{39} \mathrm{Ar}$ plateau age of $25.78 \pm 0.55 \mathrm{Ma}$, table 4$)$. Thin $(<2 \mathrm{~m})$ sedimentary sections, commonly capped by orange-brown paleosols, separate many of the flows. Owing to differential erosion, the flows tend to form pronounced ribs separated by swales underlain by the sediments. As a result, the dipping flows form a flatiron topography that is particularly pronounced on the northwest bank of Stebbins Creek. Most of these lavas have medium-potassium, tholeiitic compositions (fig. 3) and are typical of late Eocene to early Miocene volcanics of the southern Washington Cascade Range (du Bray and others, 2006; R.C. Evarts, unpub. data).

The interbedded lapilli tuff and tuff breccias (Tt) are generally pumiceous, and two of them are densely welded ignimbrites that, like the lava flows, tend to form tabular ridges. One of these is a sparsely phyric, lithic-poor, totally devitrified, hypersthene-dacite tuff that rests on the coarsely porphyritic basaltic andesite flow noted above and was traced for more than $3 \mathrm{~km}$ in lower Stebbins Creek. The other, stratigraphically higher, ignimbrite is the tuff of Stebbins Creek (Tts), a stony to vitric, sparsely plagioclase- and pyroxenephyric, rhyolitic tuff that was mapped from lower Stebbins Creek northward for $7 \mathrm{~km}$. It exhibits extremely flattened fiamme, contains very few lithic fragments, and typically looks more like a flow; in a few places, rheomorphic flow folds were observed, indicating deposition on a sloping surface. Plagioclase from the tuff of Stebbins Creek yielded an ${ }^{40} \mathrm{Ar} /{ }^{39} \mathrm{Ar}$ plateau age of $24.30 \pm 0.11 \mathrm{Ma}$.

The middle lava-flow and ignimbrite section interfingers upward with the upper volcaniclastic section that, in contrast to the lower volcaniclastic section, consists largely of pyroclasticflow deposits. Massive, green, nonwelded lapilli tuffs predominate, but densely welded beds, some vitric, are present locally. They are dacitic and more densely porphyritic than the tuffs lower in the stratigraphic section. Two widely separated welded tuffs, each within $150 \mathrm{~m}$ stratigraphically of the unconformable contact with the overlying lava flows of Hamilton Creek, yielded plagioclase ${ }^{40} \mathrm{Ar} /{ }^{39} \mathrm{Ar}$ plateau ages of $24.04 \pm 0.06 \mathrm{Ma}$ and $22.79 \pm 0.13 \mathrm{Ma}$ (table 4).

\section{Lava Flows of Hamilton Creek}

The lava flows of Hamilton Creek consist of two-pyroxene \pm olivine bearing andesite (Tha) and basaltic andesite (Thba) flows, flow breccia, and local lensoidal diamicts (Thtb) of probable laharic origin. The unit is thickest near Three Corner Rock, where it occupies a small paleovalley incised into the top of the subjacent volcaniclastic section. It thins to the south and northeast, in part due to erosion prior to deposition of the overlying Eagle Creek Formation. A coarsely porphyritic subvolcanic andesite body in Hard Scramble Creek (Tiah) may mark the vent for these flows; only a single, sparsely porphyritic dike has been found to cut the lava flows of Hamilton Creek. Chemically, the lava flows of Hamilton Creek possess transitional tholeiitic to calc-alkaline compositions (table 1; fig. 3) and differ from older lavas in the map area in their generally lower contents of $\mathrm{FeO}^{*}, \mathrm{TiO}_{2}$, and $\mathrm{P}_{2} \mathrm{O}_{5}$, higher contents of $\mathrm{Al}_{2} \mathrm{O}_{3}$ and $\mathrm{Sr}$, and higher $\mathrm{Sr} / \mathrm{Y}$ and $\mathrm{Ba} / \mathrm{Nb}$. ${ }^{40} \mathrm{Ar} /{ }^{39} \mathrm{Ar}$ ages obtained for plagioclase separates from two Hamilton Creek flows indicate they were emplaced at 22.0 to 21.6 Ma (table 4). 

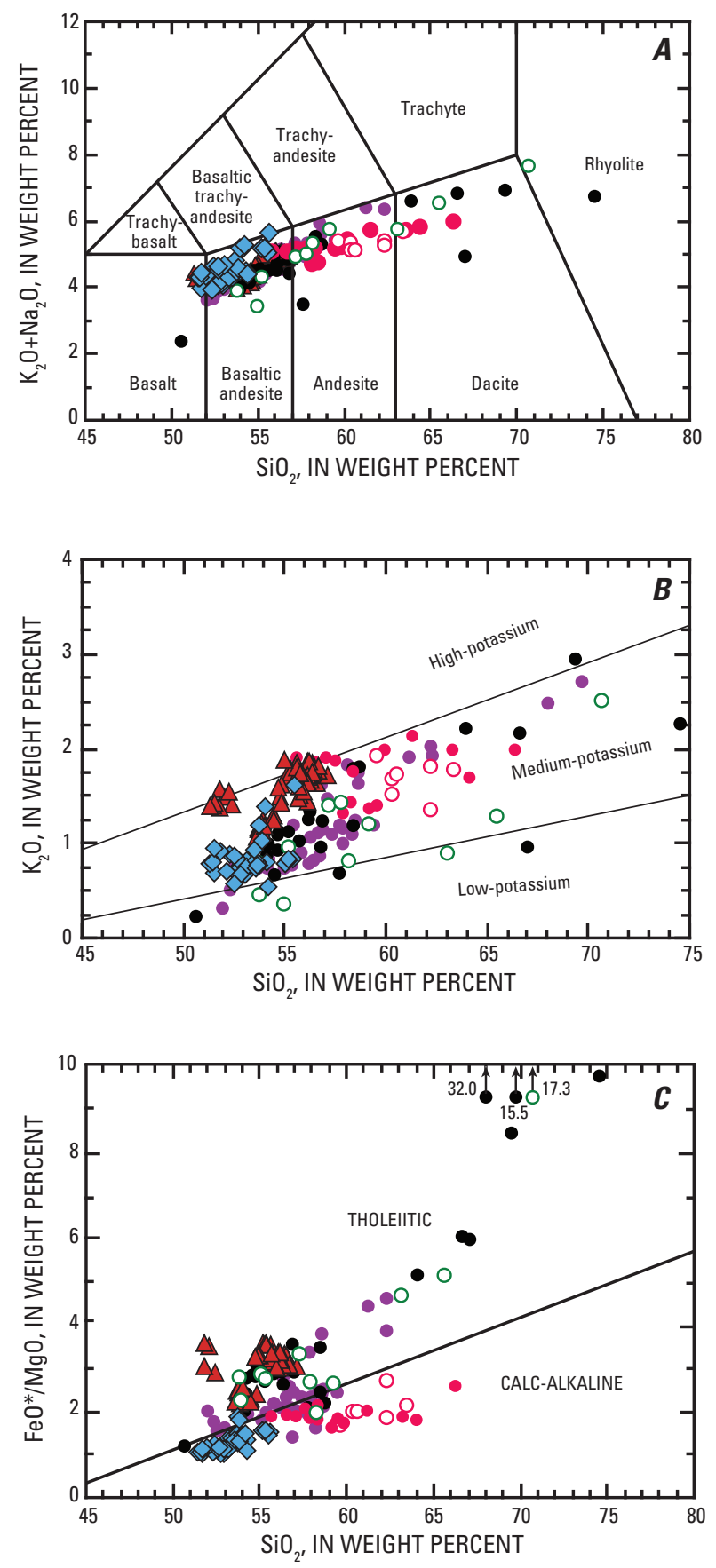

\section{EXPLANATION}

Eagle Creek Formation: oblocks in debris flows - lava flows
- Lava flows of Hamilton Creek

- Older volcanic rocks

- Tertiary intrusive rocks

Figure 3. Chemical characteristics of volcanic rocks from Beacon Rock 7.5' quadrangle (analyses recalculated volatile-free). $A, \mathrm{~K}_{2} \mathrm{O}+\mathrm{Na}_{2} \mathrm{O}$ versus $\mathrm{SiO}_{2}$ contents, showing IUGS classification (Le Maitre, 2002). $B, \mathrm{~K}_{2} \mathrm{O}$ versus $\mathrm{SiO}_{2}$ contents, showing low-, medium-, and high-potassium fields extrapolated from Gill $\left(1981\right.$, p. 6). C, $\mathrm{FeO} / \mathrm{MgO}$ versus $\mathrm{SiO}_{2}$ content, showing separation into tholeiitic and calc-alkaline rocks according to Miyashiro (1974). $\mathrm{FeO}$, total $\mathrm{Fe}$ as $\mathrm{FeO}$. 


\section{Eagle Creek Formation}

The Eagle Creek Formation underlies the crest of the divide between the Washougal and Columbia Rivers and is widely distributed in the valley of Hamilton Creek. In the map area, it rests unconformably on the lava flows of Hamilton Creek; whereas, to the east it overlies older volcaniclastic rocks. In many locations, a saprolitic paleosol as thick as $15 \mathrm{~m}$ developed on the subjacent rocks (Wise, 1961, 1970; Waters, 1973). Both upper and lower contacts of the Eagle Creek Formation are erosional surfaces of considerable relief, so its thickness varies substantially. The maximum known thickness of about $400 \mathrm{~m}$ is in Hamilton Creek (Wise, 1970).

The Eagle Creek Formation in the map area is lithologically similar to that described by Wise $(1961,1970)$ from the region to the east. It consists largely of fluvially deposited conglomerate, breccia, sandstone, and diamicts (paraconglomerates of Wise, 1970) deposited by debris flows. In comparison to older volcaniclastic rocks (Tvs, Tt), Eagle Creek beds are less consolidated and metamorphosed. East of Hamilton
Mountain, the formation is divided into two informal members. The lower member (Tecl) consists largely of fluvially deposited conglomerate and sandstone with a few relatively fine grained debris-flow beds. Clasts include a variety of volcanic rocks but are dominated by porphyritic rocks similar to those of the underlying lava flows of Hamilton Creek, presumably the source. Conglomerate matrix and finer grained sediments are considerably altered to smectitic clay, giving the rocks darkgreen to brown hues. Most of the area mapped as Eagle Creek Formation in the Beacon Rock quadrangle consists of the upper member (Tecu), which in Hamilton Creek valley rests sharply but conformably on the lower member. The upper member is dominated by poorly sorted breccias deposited by lahars (fig. 4) but also includes fluvial pebble- and cobble- conglomerate and tuffaceous sandstone, some densely packed monolithologic breccias probably emplaced as lithic pyroclastic (block-and-ash) flows, and a few lava flows. On the east valley wall of Hamilton Creek, a breccia that carries andesite megablocks many meters across may be a debris-avalanche deposit. Clasts consist chiefly of dense, porphyritic andesite and dacite; pumice clasts are

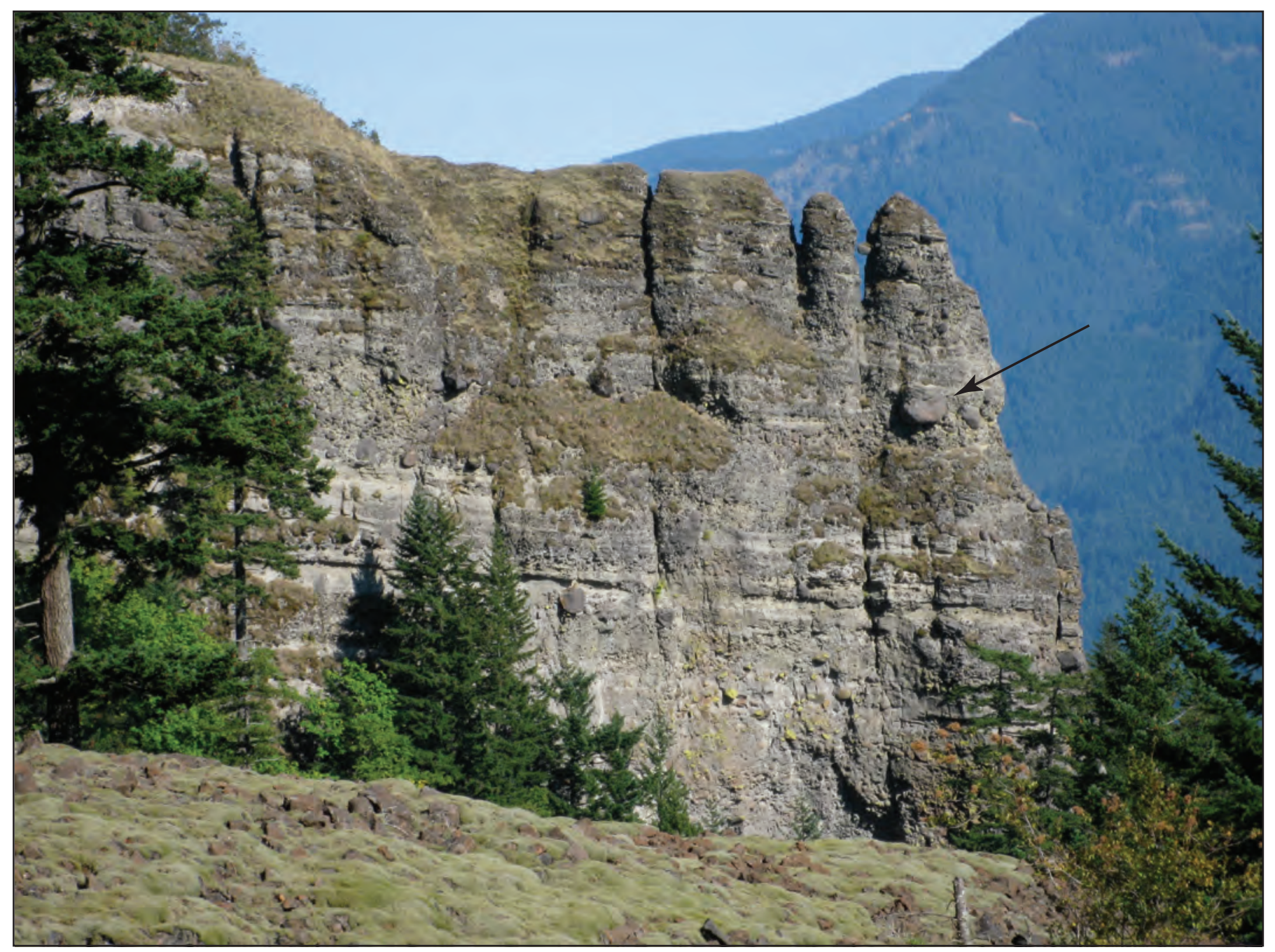

Figure 4. Cliff composed of upper Eagle Creek Formation on southeast flank of Hamilton Mountain. Consists of poorly sorted conglomerate of presumed laharic origin with minor, discontinuous sandstone beds. Large boulder near edge of cliff (arrow) is about $2.5 \mathrm{~m}$ across. 
sparse and largely restricted to sandy beds and conglomerate matrix. Upper-member rocks are much less altered than those of the lower member. They are generally light colored and weather to light-gray to white soils that contrast with the darker soils derived from older rocks and reddish-brown soils developed on the Columbia River Basalt Group. Because the resistant volcanic clasts in the conglomerates readily separate from the weak matrix, areas underlain by the Eagle Creek Formation form boulder-strewn landscapes resembling those of moraines. Clasts in Eagle Creek conglomerates and diamicts are predominantly porphyritic, pyroxene- and hornblende-phyric, intermediate to silicic volcanic rocks (table 1).

Lava flows are rare in the Eagle Creek Formation to the east (Wise, 1970) but several (Tepa, Teha, Tehd) are present in the map area (table 1; fig. 2). They consist of pyroxene- and (or) hornblende-phyric basaltic andesite and andesite that are compositionally similar to clasts in the associated lahar and block-and-ash deposits. A distinctive, densely phyric, pyroxene dacite (Tipd) crops out in the lower Hardy Creek area, where contact relations indicate it intrudes Eagle Creek Formation lava flows and clastic rocks. Northwest-trending shears are common in this area and suggest emplacement of the dacite along a fault zone. Petrographic and chemical affinities with the host rocks suggest it is a shallow intrusion of probable Eagle Creek age. The Eagle Creek lavas and clasts in debris-flow deposits exhibit calc-alkaline compositions and are clearly distinguished from older andesitic and dacitic flows by their less altered nature, nearly ubiquitous hornblende phenocrysts, and generally higher $\mathrm{Sr} / \mathrm{Y}\left(>20\right.$, fig. 5) and $\mathrm{Ba} / \mathrm{Nb} .{ }^{40} \mathrm{Ar} /{ }^{39} \mathrm{Ar}$ plateau ages on plagioclase separates from a lithic pyroclastic flow and two lava flows indicate deposition of the Eagle Creek Formation between $20.1 \mathrm{Ma}$ and 19.4 Ma (table 4).

Although both members of the Eagle Creek Formation were deposited in fluvial settings, their lithologic differences record a change in source material. The lower member consists of debris eroded from a pre-existing volcanic highland, most likely the stratovolcano that produced the lava flows of Hamilton Creek. The upper member, in contrast, reflects contemporaneous volcanism. Wise (1970) and Waters (1973) interpreted the Eagle Creek Formation as a large debris fan originating at one or more active volcanoes. This interpretation is consistent with all major characteristics of the upper member, including relatively limited compositional range and distinctive chemistry of its clasts, abundance of lahar and lithic pyroclastic-flow deposits, ash-rich matrix of many beds, high-energy depositional environment, and presence of interbedded lava flows. Northwestward thickening of the Eagle Creek Formation suggested to Wise $(1961,1970)$ that the eruptive source area was located north of the map area. Eagle Creek beds are absent in this area, however, implying that erosion has completely destroyed the original volcanic edifice, its nature and location therefore unknown. Because Eagle Creek eruptions produced abundant lithic pyroclastic flows, which are typically generated by collapse of growing andesitic and silicic domes (Cas and Wright, 1987; Freundt and others, 2000), the source area was more likely a dome field rather than a single large stratovolcano. If so, the only remains of the

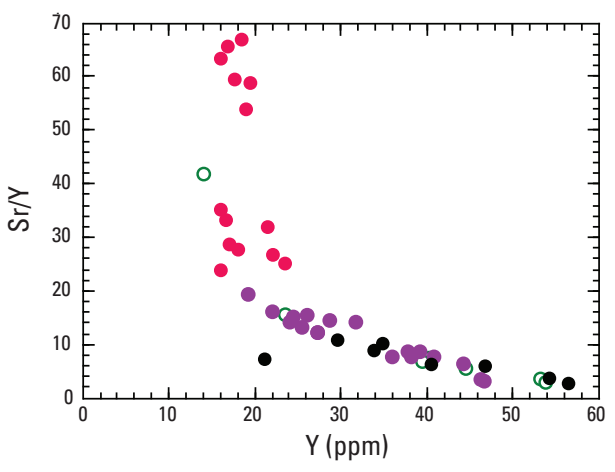

\section{EXPLANATION}

$$
\begin{aligned}
& \text { - Eagle Creek Formation lavas } \\
& \text { - Lava flows of Hamilton Creek } \\
& \text { - Tertiary intrusive rocks } \\
& \text { - Older volcanic rocks }
\end{aligned}
$$

Figure 5. Plot of $\mathrm{Sr} / \mathrm{Y}$ versus $\mathrm{Y}$ for igneous rocks in Beacon Rock 7.5' quadrangle; ppm, parts per million.

Eagle Creek volcanic center would likely be small subvolcanic intrusions scattered throughout the area north of the Eagle Creek Formation outcrop belt. Three possible Eagle Creek vents are mapped in the Beacon Rock quadrangle. One is the hill in the center of the map area informally named "Croswell Butte" that consists of a blocky-surfaced deposit of hornblende dacite (Tehd); because highly viscous dacite cannot flow far from its source vent, this outcrop is likely a dome or shallow plug. A second possible vent is an intrusion of fresh andesite located about $4 \mathrm{~km}$ to the east, near Lily Lake. The Lily Lake body (Tial) is aphyric, unlike most Eagle Creek clasts, but possesses certain distinctive chemical characteristics, such as a high $\mathrm{Sr}$ content and high $\mathrm{Sr} / \mathrm{Y}$, that indicate an affinity to Eagle Creek magmas. Finally, a densely porphyritic dacite body cutting the Eagle Creek Formation in Hardy Creek (Tipd) also has relatively high $\mathrm{Sr}$ and $\mathrm{Sr} / \mathrm{Y}$ and may be a late Eagle Creek-age subvolcanic intrusion.

\section{Intrusive Rocks}

A wide variety of intrusive rocks were emplaced into the older part of the Oligocene to early Miocene section of the Beacon Rock quadrangle. They range from phaneritic, variably altered, gabbro, pyroxene diorites, and quartz diorites (Tgb, Tdi, Tqd), presumably emplaced at considerable depth, to finegrained, locally vitric, mafic to silicic rocks (Tiba, Tia, Tid) forming (possibly subvolcanic) dikes, sills, and plugs.

The largest intrusions in the map area, in the Deer Creek drainage, consist of moderately porphyritic dacite $\left(\mathrm{Tidc}_{\mathrm{d}}\right.$ ) to rhyolite ( Tidc $_{\mathrm{r}}$ ) distinguished by chalky white plagioclase phenocrysts in a buff to light-gray, felsitic groundmass. These rocks are highly jointed, extensively frost-heaved, and commonly disintegrate to barren talus. Plagioclase from a rhyolite sample on the ridge east of Deer Creek yielded an ${ }^{40} \mathrm{Ar} r{ }^{39} \mathrm{Ar}$ plateau age of $22.60 \pm 0.06 \mathrm{Ma}$. 
The ages of other intrusions in the map area are poorly constrained. Those that cut the lowest stratigraphic horizons near the northwest corner of the quadrangle are generally altered as much as or more than their host rocks and may predate the pervasive low-grade metamorphism affecting those rocks (see next section). Elsewhere, many intrusive bodies are less altered than their host rocks and could be much younger. $\mathrm{An}{ }^{40} \mathrm{Ar} /{ }^{39} \mathrm{Ar}$ experiment on one intrusion, exposed in Hard Scramble Creek (Tiah), did not yield a specific age but provides a maximum age of $23.14 \pm 0.18 \mathrm{Ma}$, permissive of a Hamilton Creek source vent (table 4). The only intrusions known to cut Hamilton Creek flows are the plug of platy aphyric andesite forming a conical hill south of Lily Lake (Tial) and an isolated sparsely phyric andesite dike about $4.2 \mathrm{~km}$ to the west. Neither of them petrographically resembles either the lava flows of Hamilton Creek or rocks of the Eagle Creek Formation, although, as noted above, the Lily Lake body is chemically similar to flows in the Eagle Creek Formation.

A distinctive, densely phyric, pyroxene dacite (Tipd) crops out in the lower Hardy Creek area, where contact relations indicate it intrudes Eagle Creek Formation lava flows and clastic rocks. Northwest-trending shears are common in this area and suggest emplacement of the dacite along a fault zone. Petrographic and chemical affinities with the host rocks suggest it is a shallow intrusion of probable Eagle Creek age.

\section{Metamorphism and Hydrothermal Alteration}

The ashy matrix of Eagle Creek Formation volcaniclastic rocks has typically been converted to iron-poor montmorillonite but otherwise the unit is unaltered (Wise, 1961). Underlying rocks, however, have been subjected to zeolite-facies regional metamorphism similar to that described from other areas in the southern Washington Cascade Range (Fiske and others, 1963; Wise, 1970; Evarts and others, 1987; Evarts and Swanson, 1994). This region-wide metamorphism reflects burial within the relatively high heat-flow environment of an active volcanic arc.

The degree of alteration in the sub-Eagle Creek rocks of the map area increases downsection. Alteration of the lava flows of Hamilton Creek is generally limited to partial replacement of olivine, orthopyroxene, and interstitial glass by iron-rich smectite. Alteration of associated tuff breccia is similarly limited. The weak alteration is consistent with shallow burial depths, less than $0.5 \mathrm{~km}$, beneath the Eagle Creek Formation.

Metamorphic effects are more apparent in the volcaniclastic strata below the lava flows of Hamilton Creek, especially in originally vitric tuffs, most of which have been pervasively converted to iron-bearing smectites with or without celadonite, clinoptilolite, or analcime. In the lowest part of the sequence northwest of Stebbins Creek, minerals indicative of somewhat higher temperatures (albite, stilbite, laumontite, prehnite, pumpellyite, chlorite) are widely developed.

The highest temperature metamorphic assemblages in the map area, characterized by the presence of epidote, occur in an area of abundant dikes near the mouth of Stebbins Creek. Epidote-bearing propylitic alteration is closely associated with concentrations of intrusive rocks elsewhere in the Cascade Range and reflects hydrothermal activity rather than simple burial (Grant, 1969; Evarts and others, 1987; Evarts and Swanson, 1994). The exposed dikes, despite their abundance, seem insufficient to account for the intensity of propylitization in the Washougal River area, indicating that they may be offshoots from a substantial intrusive body in the shallow subsurface.

The timing of metamorphism is difficult to ascertain. Peak metamorphism presumably corresponds to the time of maximum burial and (or) maximum intrusive activity. Maximum burial in the map area occurred during deposition of the Eagle Creek Formation, about $20 \mathrm{Ma}$. This is consistent with regional relations that indicate a substantial decline in arc volcanism in southern Washington prior to eruption of the Columbia River Basalt Group (Evarts and Swanson, 1994). The few intrusive rocks in the area that have been dated yield early Miocene ages. Metamorphism in the northeastern part of the map area may be related to emplacement of the large granitic Silver Star stock, $5 \mathrm{~km}$ to the west, which has a K-Ar age of 19.6 $\pm 0.7 \mathrm{Ma}$ (Power and others, 1981). These observations suggest that metamorphism culminated in the early Miocene.

\section{Columbia River Basalt Group}

In the Miocene, between 16.5 and $6 \mathrm{Ma}$, huge volumes of tholeiitic flood basalt, erupted from fissures in southeastern Washington and adjacent Oregon and Idaho, formed the Columbia River Basalt Group. Some of the largest flows crossed the Cascade Range through a broad lowland and ultimately reached the Pacific Ocean (Beeson and others, 1989; Pfaff and Beeson, 1989; Beeson and others, 1989; Wells and others, 1989, 2009). The Columbia River Gorge is located near the northern margin of the Miocene lowland, where the flows are banked against the dissected erosional surface of the Eagle Creek Formation. Most of the flood-basalt flows erupted during a brief period between 16 and $15 \mathrm{Ma}$ and constitute the voluminous Grande Ronde Basalt and Wanapum Basalt (Beeson and others, 1989; Tolan and others, 1989; Reidel and others, 1989a, 2013; Reidel and Tolan, 2013; Barry and others, 2010, 2013; Baksi, 2013). After emplacement of the Wanapum Basalt, flood-basalt eruptions became less frequent, and the ancestral Columbia River incised a deep canyon that confined the youngest flows (Waters, 1973; Tolan and Beeson, 1984; Beeson and others, 1989). The locations of the erosional remnants of Columbia River Basalt Group flows in the map area are shown on figure 2. Figure 6 portrays the stratigraphic nomenclature of the Columbia River Basalt Group employed in this report and shows the stratigraphic position of units found in the map area.

Columbia River Basalt Group flows possess the general character of pahoehoe lavas (Self and others, 1997; Thordarson and Self, 1998; Vye-Brown and others, 2013) and typically exhibit one of two distinctive cooling-jointing patterns referred to as blocky/columnar and entablature/colonnade (fig. 6; Waters, 1973; Long and Wood, 1986; Beeson and others, 1989; Tolan and others, 2009). Flows with entablature/colonnade 


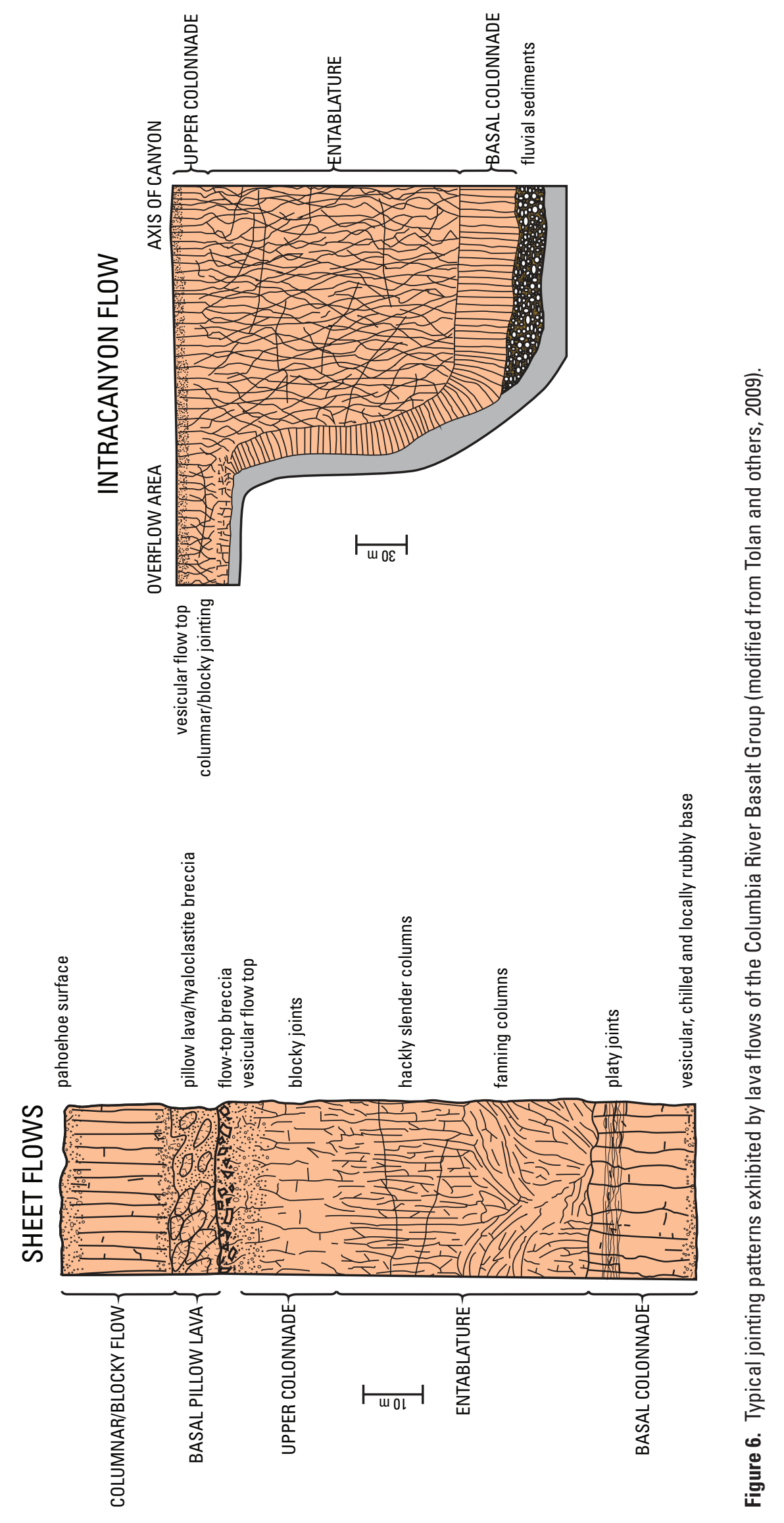


jointing (the Type I flows of Long and Wood, 1986) have a basal zone of well-formed columns, 0.5 to $2 \mathrm{~m}$ across, overlain by a hackly-jointed entablature composed of thinner, poorly developed columns. The entablature commonly constitutes more than 50 percent of the flow thickness. Although much more densely jointed, entablatures, due to the interlocking nature of their curviplanar joints, are more resistant to erosion and tend to form the largest and most continuous cliffs. Blocky/columnar jointing (equivalent to the Type III flows of Long and Wood, 1986) is typically associated with thinner flows and consists of poorly developed vertical columns and horizontal cross joints. Internal jointing in some flows, however, may be complex, with multiple colonnades or entablatures (Type II flows of Long and Wood, 1986; McMillan and others, 1989; Tolan and others, 2009). Flow tops are vesicular and commonly weathered.

As noted by others (Reidel, 1998; Self and others, 1997; Thordarson and Self, 1998; Vye-Brown and others, 2013), defining precisely what constitutes a lava flow in flood-basalt provinces is not entirely straightforward. For mapping purposes, a flow, as used here, consists of a body of basalt with a jointing pattern that indicates it was emplaced and cooled during a single continuous event (sometimes referred to as cooling units (Reidel, 1998)). We have observed apparent contacts between cooling units that are chemically identical, suggesting that these contacts separate sheet-like flow lobes emplaced during a single eruptive episode. Contacts between lobes record breaks in deposition that range from a few hours to several years (Self and others, 1997; Thordarson and Self, 1998; Vye-Brown and others, 2013). The collection of flows and lobes produced by a single sustained eruption constitute a flow field composed of lavas with generally uniform compositions. Although flow tops are almost universally vesicular, internal vesicular zones are not uncommon (Long and Wood, 1986; Tolan and others, 2009). As noted above, individual flows may also show internally complex jointing. Furthermore, jointing patterns in individual flows may change laterally over distances of less than $100 \mathrm{~m}$. These complications can render distinguishing flow contacts from internal boundaries difficult. The most reliable field indicators of interflow contacts, none that are common, include sedimentary interbeds, tree molds, oxidation, basal pillow lava-hyaloclastite zones, pipe vesicles, and flow breccia; cooling directions inferred from features on joint surfaces (DeGraff and others, 1989) are also useful. Despite the impression of sheetlike layers one gets from the seemingly continuous cliffs and stair-step topography in the Columbia River Gorge, detailed mapping and geochemistry suggest that Columbia River Basalt Group flows in the map area can vary substantially in thickness over relatively short distances.

\section{Grande Ronde Basalt}

Grande Ronde Basalt flows are generally aphyric to sparsely plagioclase-phyric, medium-potassium, tholeiitic basaltic andesites (fig. 3) that are readily distinguished from those in the other formations of the group by their generally aphyric character and comparatively high $\mathrm{SiO}_{2}$ and low $\mathrm{TiO}_{2}$ contents (Swanson and others, 1979b; Mangan and others, 1986; Beeson and others, 1989; Reidel and others, 1989a; Hooper, 1997; Reidel and Tolan, 2013). We estimate that about 12 individual eruptions are represented by flows exposed in the map area.

Grande Ronde Basalt flows in the map area range from aphyric to sparsely phyric with widely scattered plagioclase phenocrysts or glomerocrysts less than $10 \mathrm{~mm}$ across. Some flows are distinctly microphyric, with abundant plagioclase microphenocrysts $\leq 1 \mathrm{~mm}$ long. They consist largely of plagioclase, augite, pigeonite, Fe-Ti oxide, apatite, and dark glass; some flows contain minor olivine or orthopyroxene (Reidel and others, 1989a; Reidel and Tolan, 2013). Textures range from intergranular to intersertal; samples from colonnades are more coarsely crystalline than those from entablatures, which typically contain 35 to 65 percent glass (Long and Wood, 1986). In general, Grande Ronde flows are petrographically indistinguishable, although variations in the abundance of phenocrysts or microphenocrysts are locally useful.

The widespread and originally horizontal Grande Ronde Basalt flows potentially constitute excellent stratigraphic datums for analysis of post-middle-Miocene deformation (Beeson and others, 1989; Beeson and Tolan, 1990), but the remarkable physical and chemical similarity of these flows stymied early attempts to construct an internal stratigraphic framework for this thick formation. Swanson and others (1979b) showed that emplacement of the flood-basalt field spanned three paleomagnetic polarity reversals, allowing subdivision of the formation into four magnetostratigraphic units (fig. 7). Chemical analyses demonstrated that Grande Ronde flows could be divided into relatively high- $\mathrm{MgO}$ and low- $\mathrm{MgO}$ groups (fig. 8), with a gap at about 4.0 weight percent $\mathrm{MgO}$ (Reidel, 1983; Mangan and others, 1986). Employing a combination of petrographic characteristics, stratigraphic position, chemistry, and paleomagnetic properties, Reidel and others (1989a) developed an informal stratigraphic nomenclature for the Grande Ronde Basalt. We find this nomenclature useful and have adopted it, as revised and formalized by Reidel and Tolan (2013), for our mapping in the western Columbia River Gorge (fig. 7). Reidel and Tolan (2013) divided the Grande Ronde Basalt in the Columbia Basin into 25 formal and informal members based primarily on chemical composition; six of these members, mostly within the $\mathrm{N}_{2}$ and $\mathrm{R}_{2}$ magnetostratigraphic units of Swanson and others (1979b), are recognized in the map area. The members defined by Reidel and Tolan (2013) typically contain several chemically distinguishable flows or packages of flows, each probably equivalent to a flow field emplaced during a single, sustained eruption.

\section{Analytical Issues}

Assignment of Grande Ronde flows to Reidel and Tolan's (2013) members requires precise chemical analyses to detect the subtle compositional differences between units. Interlaboratory bias and weathering effects complicate assessments. To eliminate potential analytical bias, all analyses reported here (table 2) are from the Peter Hooper GeoAnalytical Laboratory at Washington State University using common instrumentation and standards. Although internally consistent, our data cannot 

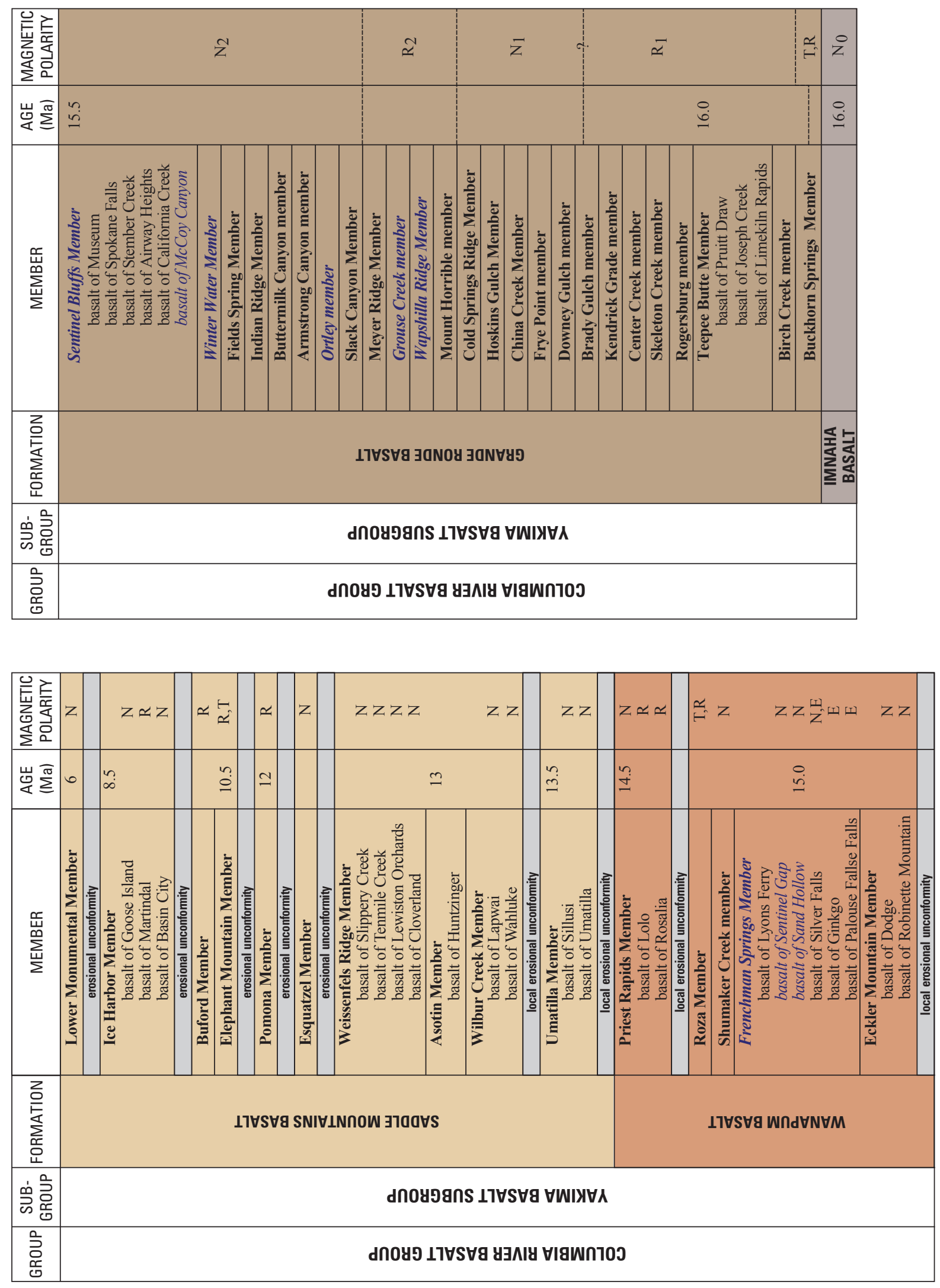

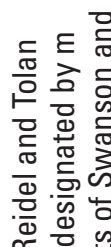

品竞参

实 틓 क $E$ 흘 흠 동 드용 흫 雨 E 이항 $\sum \sum \frac{\pi}{\omega}$ 这的 흥흠 E d 응음 言策弯 흥 흠 흐 ๙ 으 0 更 क 증 ख 든든

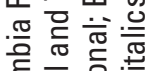
흥 응 을 긍 흥 :퐁 흥 舟政. 我度 힣ㅎㅇ क्ष : 응 중 은 동 인히 듐늉 $\varepsilon$ 原 吃 放

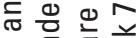
s. बㄷำ

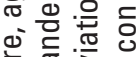

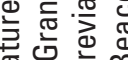
흔ㅎㅁ잉 읃

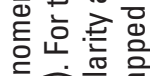
을 낭흠 응으.․ㄹㅇ 흔 元 क 这 0

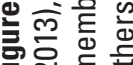

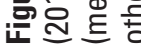



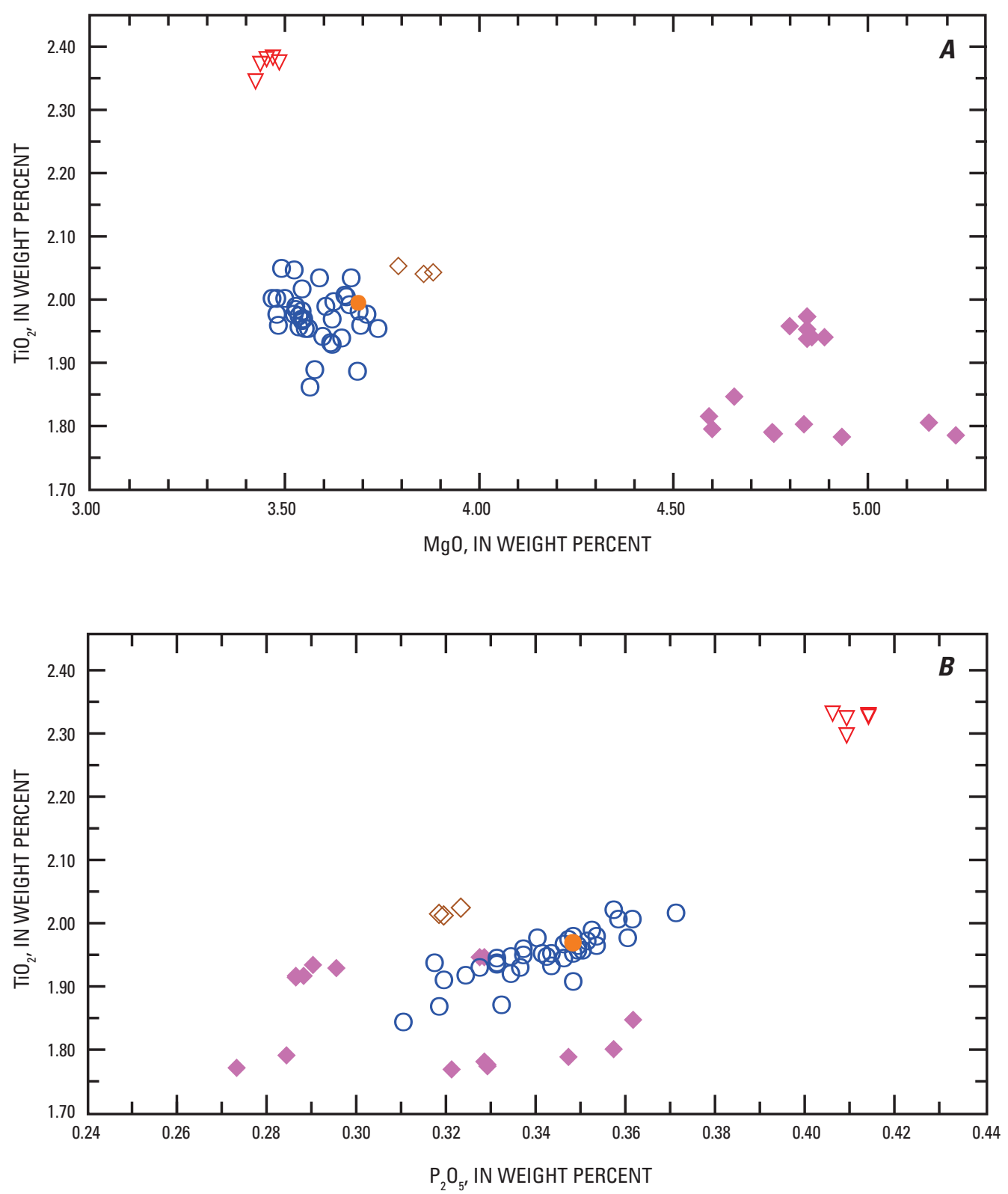

EXPLANATION

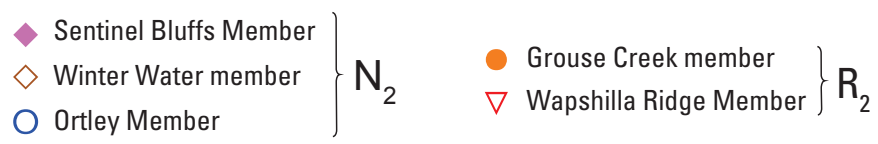

Figure 8. Chemical characteristics of Grande Ronde Basalt flows in the Beacon Rock 7.5' quadrangle. $\mathrm{N}_{2}$ and $\mathrm{R}_{2}$ are magnetostratigraphic units of Swanson and others (1979b). $A, \mathrm{TiO}_{2}$ versus $\mathrm{MgO}$ contents. $B, \mathrm{TiO}_{2}$ versus $\mathrm{P}_{2} \mathrm{O}_{5}$ contents.

be compared directly to analyses performed in other labs or even with older data from the Washington State University laboratory (for example, Reidel and others, 1989a) that were produced using different equipment and data-reduction procedures.

A major difficulty in making correlations among Grande Ronde flows is accounting for the effects of chemical weathering, which can modify rock chemistry sufficiently to produce erroneous member assignments (Wells and others, 2009).
Consequently, we rely mainly on analyses that meet two criteria related to extent of weathering. First is degree of hydration as recorded by loss-on-ignition or by anhydrous totals. We judge samples that have loss-on-ignition exceeding 3.0 weight percent, or anhydrous totals less than 97 weight percent, as possibly affected by weathering, although simple hydration will not affect normalized compositions. The second and more important criterion is total $\mathrm{Fe}$ calculated as $\mathrm{FeO}\left(\mathrm{FeO}^{*}\right)$ for 
normalized analyses (Wells and others, 2009). Most fresh Grande Ronde flows contain at least 11 weight percent $\mathrm{FeO}^{*}$ (see Hooper, 2000; Reidel and Tolan, 2013), and we therefore consider samples with less than 11 weight percent $\mathrm{FeO}^{*}$ as potentially altered. Importantly, this is true even for samples with anhydrous totals above 98 weight percent and for samples that appear fresh in hand sample and thin section. We interpret the reduction in $\mathrm{FeO} *$ to reflect long-duration chemical reaction with groundwater. This process can affect elements such as $\mathrm{MgO}, \mathrm{TiO}_{2}$, and $\mathrm{P}_{2} \mathrm{O}_{5}$ that are used to help distinguish Grande Ronde Basalt members. Therefore, we do not rely on data from rocks that have less than 11 weight percent $\mathrm{FeO}^{*}$ for member assignments. Most analyses in table 2 are unaltered according to this criterion.

We also employ laboratory paleomagnetic analyses to distinguish Grande Ronde Basalt flows in the map area (table 5). This approach has two major advantages over field determinations with a portable fluxgate magnetometer. Firstly, chemical magnetic overprints resulting from post-emplacement weathering can be detected and eliminated, producing less ambiguous results. Secondly, the data provide paleomagnetic inclinations and declinations as well as polarities, potentially allowing chemically similar flows within a magnetostratigraphic unit to be differentiated (Wells and others, 1989, 2009).

Grande Ronde Basalt flows in the map area exhibit a pronounced onlap relation with the south-sloping paleovalley wall underlain by the Eagle Creek Formation. As a result, the number of flows and overall thickness of the formation decrease northward and the unit is absent north of the Columbia River valley. Our detailed chemical stratigraphy reveals major variations in the thickness of individual flows across the map area. These variations reflect, in part, the lobate character of Columbia River Basalt flows (Self and others, 1997; Thordarson and Self, 1998; Vye-Brown and others, 2013), which is probably best developed at locations near the province margins (Reidel, 1998). However, some of the more dramatic thickness changes, exemplified by the thick Ortley member flow at Hamilton Mountain, clearly record significant erosion during the relatively brief periods separating emplacement of Grande Ronde Basalt flows. The resulting intracanyon relations between Grande Ronde flows have not been described from elsewhere in the flood-basalt province. Such enhanced interflow erosion is likely restricted to areas at the margin of the province, where major tributaries of the ancestral Columbia River encountered the flow field and were shunted along its edge, carving canyons that were filled by succeeding lava flows (Wells and others, 2009). Another manifestation of interaction between basalt flows and tributary streams is the abundance of pillow lavas and hyaloclastite in the Grande Ronde section of the map area.

\section{Wapshilla Ridge Member}

The lowest Columbia River Basalt Group flows exposed in the map area belong to the Wapshilla Ridge Member (Tgwr) of Reidel and Tolan (2013). They are reversely magnetized, have relatively low $\mathrm{MgO}$ contents (3.3-3.6 weight percent) and possess higher $\mathrm{TiO}_{2}(2.3-2.4$ weight percent $)$ and $\mathrm{P}_{2} \mathrm{O}_{5}$ contents (about 0.4 weight percent) than most other low-MgO Grande Ronde flows in western Oregon and Washington (table 2; fig. 8; Reidel and others, 1989a; Beeson and others, 1989). Wapshilla Ridge flows are nearly aphyric but contain abundant plagioclase microphenocrysts; this microphyric character is indicative but not diagnostic. Only the uppermost Wapshilla Ridge flow in the Columbia River Gorge crops out in the Beacon Rock quadrangle; it is found on the slopes of Hamilton Mountain, on the ridge west of Hardy Creek, and in a box canyon near the southwest corner of the map area. In the first two locations, it overlies and pinches out northward against the Eagle Creek Formation; in the third locality it probably overlies older Wapshilla Ridge Member flows that are buried by talus. This flow is distinguished from older Wapshilla Ridge flows by a slightly but consistently higher $\mathrm{P}_{2} \mathrm{O}_{5}$ content ( $\geq 0.40$ weight percent; fig. 8) (Wells and others, 2009; R.C. Evarts, unpub. data).

\section{Grouse Creek Member}

The Grouse Creek member (Tggc) directly overlies the Wapshilla Ridge Member in the western Columbia River Gorge. Grouse Creek flows, like Wapshilla Ridge flows, are reversely magnetized and belong to the $\mathrm{R}_{2}$ magnetostratigraphic unit of Swanson and others (1979b). Grouse Creek flows are generally aphyric and generally not microphyric (Reidel and Tolan, 2013). Only one Grouse Creek member flow crops out in the map area, at the head of the box canyon near the southwest corner of the map. It is characterized by moderately low $\mathrm{MgO}$ (about 3.6-3.7 weight percent) and relatively high $\mathrm{P}_{2} \mathrm{O}_{5}$ (about 0.36 weight percent) contents (table 2; fig. 8) and an unusual, low-inclination, magnetic direction (table 5; J.T. Hagstrum, written commun., 2010).

\section{Ortley Member}

Ortley member (Tgo) flows in the map area are lithologically and chemically similar to underlying Grouse Creek member flows (table 2) but exhibit normal magnetic polarities (Reidel and others, 1989a; Beeson and others, 1989; Reidel and Tolan, 2013). Most Ortley flows in the Beacon Rock quadrangle exhibit entablature/colonnade jointing patterns and are aphyric but not microphyric. The Ortley member is the thickest Grande Ronde Basalt member in the map area, and Ortley flows are some of the thickest individual Grande Ronde flows. Thick Ortley member sections underpin the ridges east and west of Hardy Creek. All paleomagnetically sampled flows in the Beacon Rock quadrangle belong to this member (fig. 9).

The landslide scarp that forms the high cliff of the south face of Hamilton Mountain provides a spectacular exposure of an intracanyon Grande Ronde Basalt flow (fig. 10; Waters, 1973; Wells and others, 2009). There, a 200-m-thick Ortley member flow occupies a paleovalley incised through the Wapshilla Ridge Member into the underlying Eagle Creek Formation, probably by a tributary of the ancestral Columbia River that entered the trans-arc lowland from the north. The basalt flow consists of a thick entablature over a thin, curving colonnade, banked against Eagle Creek Formation sedimentary 


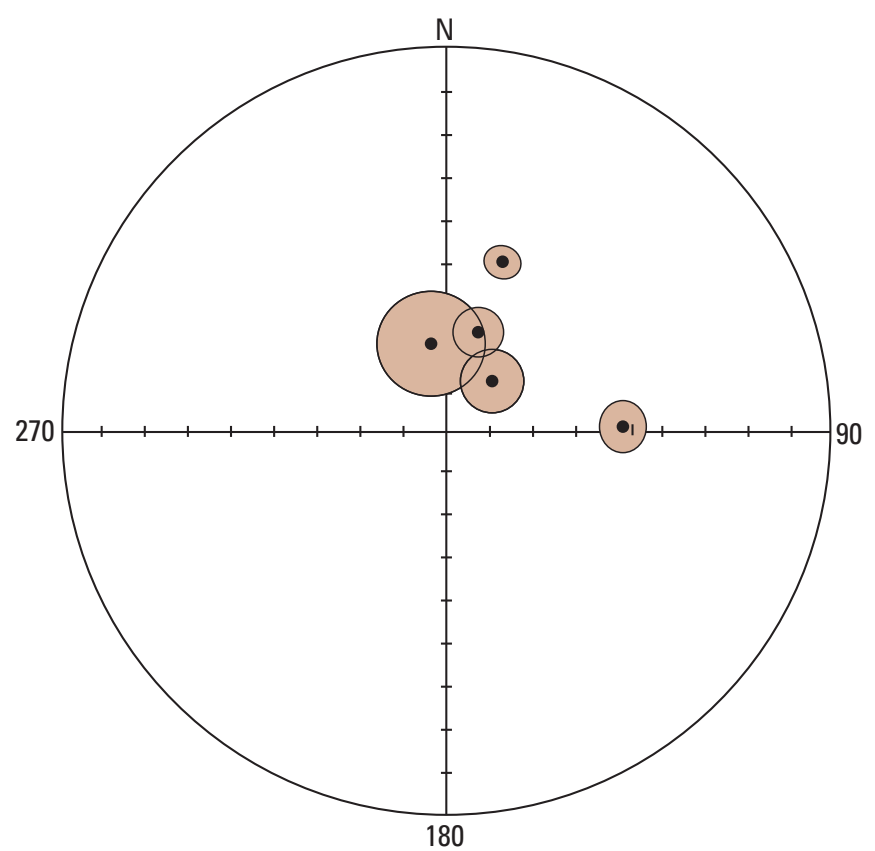

Figure 9. Paleomagnetic directions for Grande Ronde Basalt flows in the Beacon Rock 7.5' quadrangle. Dots show lower-hemisphere (normal) directions. Thin lines outline areas of 95 percent confidence intervals. All sampled flows exhibit normal magnetic polarity and are assigned to the informal Ortley member of Reidel and Tolan (2013).

rocks on the east and overlying a thick deposit of pillow breccia and palagonitic hyaloclastite on the west. The hyaloclastic section, characterized by steeply north dipping foreset beds, is as thick as $100 \mathrm{~m}$ but pinches out abruptly to the north. Pillow fragments in the hyaloclastite are compositionally similar to the overlying flow, suggesting that they are products of the same eruption. The clastic wedge is interpreted as a delta that formed in a temporary lake created when the lava flow blocked the south-flowing tributary of the ancestral Columbia River. Later in the eruption, the lake water apparently drained away, allowing the basalt to flow down the delta front and fill the paleovalley.

\section{Winter Water Member}

The Winter Water member (Tgww) is the uppermost low- $\mathrm{MgO} \mathrm{N} \mathrm{N}_{2}$ member in the Grande Ronde Basalt (Reidel and others, 1989a; Beeson and others, 1989; Reidel and Tolan, 2013). Winter Water flows can be differentiated from most other Grande Ronde flows by the presence of scattered ( $<1$ percent) plagioclase phenocrysts and radial, spokelike glomerocrysts (Tolan, 1982; Reidel and others, 1989a; Reidel and Tolan, 2013). In addition, some Winter Water flows exhibit an unusually shallow paleomagnetic inclination (Reidel and others, 1989a; Wells and others, 1989, 2009; J.T. Hagstrum, written commun., 2010). Two chemically and paleomagnetically distinguishable Winter Water flows crop out in the western Columbia River Gorge (Wells and others, 2009; R.C. Evarts, unpub. data) but only the upper one is present in the Beacon Rock quadrangle. Its chemical composition (table 2) is similar to that of some Grouse Creek and Ortley flows but it can be distinguished by a consistently lower $\mathrm{Ba}(<600 \mathrm{ppm})$ content, normal magnetic polarity, shallow paleomagnetic inclination (table 5; J.T. Hagstrum, written commun., 2010), and relatively abundant plagioclase phenocrysts. This flow exhibits a colonnade/entablature jointing pattern in which the entablature constitutes more than 90 percent of the flow thickness. It forms an imposing 60-m-high cliff on the west side of the box canyon near the southeast corner of the quadrangle but thins northward and is very thin or absent about $1.5 \mathrm{~km}$ to the north, where the Sentinel Bluffs Member rests directly on the Ortley member. The same Winter Water member flow crops out on the crest of the ridge west of Hardy Creek, where it is about $40 \mathrm{~m}$ thick, but is absent from the Grande Ronde Basalt section on (informally named) Birkenfeld Mountain, $5 \mathrm{~km}$ to the north. Its absence probably reflects erosion at the edge of the Miocene paleovalley prior to emplacement of the younger Sentinel Bluffs Member.

\section{Sentinel Bluffs Member}

The Sentinel Bluffs Member (Tgsb) is the uppermost member of the Grande Ronde Basalt (Reidel and others, 1989a; Reidel, 2005; Reidel and Tolan, 2013). Sentinel Bluffs flows are characterized by relatively high $\mathrm{MgO}$ contents (4.4 to 5.0 weight percent; table 2; fig. 8) and normal magnetic polarity. Some flows contain widely scattered plagioclase phenocrysts 5 to $15 \mathrm{~mm}$ long. Tolan (1982) referred to these as high- $\mathrm{MgO} \mathrm{N}_{2}$ flows. Sentinel Bluffs Member flows in the western Columbia River Gorge typically exhibit a blocky to columnar jointing style except near flow margins, where an entablature/colonnade jointing pattern may be found (Tolan, 1982; Beeson and others, 1989; Reidel, 2005). In the Beacon Rock quadrangle, the Sentinel Bluffs Member crops out in scattered localities on and southeast of the Washougal-Columbia divide. Its maximum thickness is about $75 \mathrm{~m}$ on Birkenfeld Mountain east of Hamilton Creek.

Reidel (2005) divided the Sentinel Bluffs Member into six compositional types, each associated with a stratigraphically confined lava flow or flow package; three of these compositional types, comprising four flows, are found in the map area (but were not mapped separately). The uppermost flow is assigned to the basalt of Museum of Riedel (2005), which is the youngest Sentinel Bluffs unit in the Columbia Basin. This flow is vaguely to distinctly microphyric and exhibits a colonnade/ entablature jointing pattern. It is distinguished from the other Sentinel Bluffs flows by a combination of high $\mathrm{MgO}$ and low $\mathrm{TiO}_{2}$ contents (table 2; fig. 8). The basalt of McCoy Canyon, the oldest and most voluminous Sentinel Bluffs compositional type (Riedel, 2005), is represented in the map area by two flows with distinct compositions, including one that has a lower $\mathrm{Cr}$ content than other Sentinel Bluffs flows in the quadrangle (table 2). Although McCoy Canyon flows crop out in several localities, the only place where both flows occur is on Hardy Ridge, where the lower-Cr flow overlies the higher-Cr flow, a relation observed at other locations in the western Columbia River Gorge (R.C. Evarts, unpub. data). A flow with a composition higher in $\mathrm{MgO}$ than the basalt of Museum, lower in $\mathrm{TiO}_{2}$ 


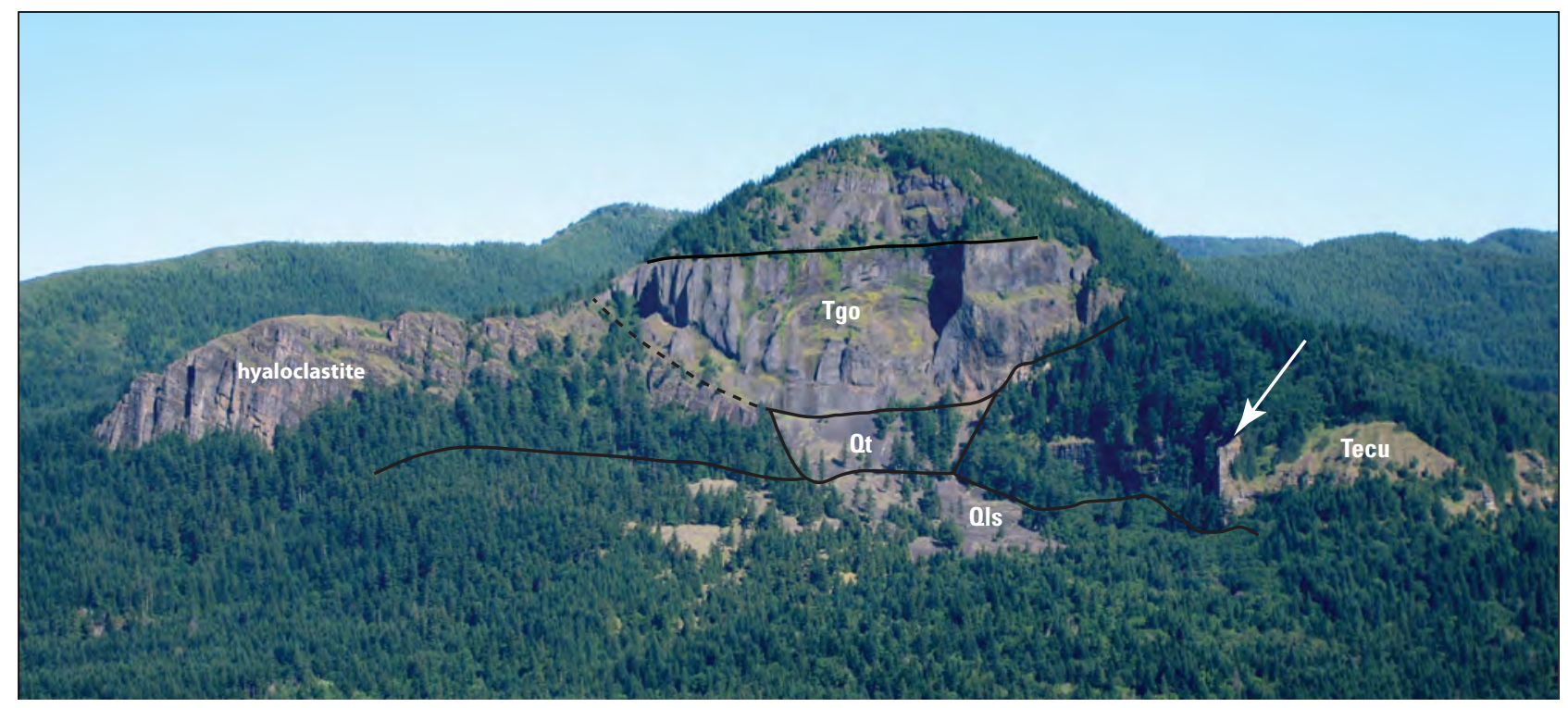

Figure 10. South face of Hamilton Mountain showing $200-m$-thick intracanyon Grande Ronde Basalt flow overlying basal foreset-bedded pillow breccia of same flow on the left and Eagle Creek Formation (Tecu) on the right. All visible flows belong to the informal Ortley member (Tgo) of Riedel and Tolan (2013). Arrow points to cliff of Eagle Creek Formation shown in figure 3. Ot, talus; Qls, landslide deposits.

than the basalt of McCoy Canyon, and lower in $\mathrm{P}_{2} \mathrm{O}_{5}$ and higher $\mathrm{Cr}$ than either (table 2) is found at scattered locations in the map area. It is relatively thin $(<20 \mathrm{~m}$ thick) and generally exhibits blocky/columnar jointing. Where in contact with other Sentinel Bluffs Member flows, as on Birkenfeld Mountain, it always lies above the basalt of McCoy Canyon and below the basalt of Museum. Flows of this composition and stratigraphic position in the Columbia Basin belong to the basalt of Stember Creek of Riedel (2005).

\section{Wanapum Basalt}

Wanapum Basalt flows are generally more mafic, darker, and more coarsely crystalline than Grande Ronde Basalt flows and characteristically contain scattered plagioclase phenocrysts and glomerocrysts as large as $5 \mathrm{~cm}$ across (Mackin, 1961; Swanson and others, 1979b). Compositionally, Wanapum flows have much higher $\mathrm{TiO}_{2}$ contents (Swanson and others, 1979b; Hooper, 1997). The Wanapum Basalt has been divided into formal members (Swanson and others, 1979b; Tolan and others, 1989; Reidel and others, 2013); the Frenchman Springs Member (Beeson and others, 1985; Martin and others, 2013) is present in the map area.

\section{Frenchman Springs Member}

Flows assigned to the Frenchman Springs Member crop out between McCloskey and Duncan Creeks in the southwestern part of the quadrangle and at the summit of Birkenfeld Mountain. In both locations, they directly overlie the Sentinel Bluffs Member of the Grande Ronde Basalt. In the Columbia Basin, these units are separated by a sedimentary interval, the Vantage Member of the Ellensburg Formation (Swanson and others (1979b). In the map area, as elsewhere throughout western Washington and Oregon, the Vantage Member is very thin $(<1 \mathrm{~m})$ or absent (Beeson and others, 1989), but the Grande Ronde-Wanapum contact is readily mapped based on the distinctly different physical and chemical properties of the two formations.

Martin and others (2013) divide the Frenchman Springs Member into five units on the basis of composition, paleomagnetic properties, stratigraphic position, and lithologic features. Most Frenchman Springs Member outcrops in the map area are assigned to the basalt of Sand Hollow (Twfs $_{h}$ of Beeson and others (1985) and Martin and others (2013). The basalt of Sand Hollow is the most voluminous unit of the Frenchman Springs Member and one Sand Hollow flow reached the Pacific Ocean (Beeson and others, 1985; Wells and others, 1989, 2009; Martin and others, 2013). Sand Hollow flows are distinguished by the persistent presence of amber plagioclase phenocrysts as much as $35 \mathrm{~mm}$ long and by relatively high $\mathrm{Cr}$ content (37-45 ppm).

Two small knobs on the flat ridgecrest south of McCloskey Creek consist of similar basalt but contain only scarce plagioclase phenocrysts and display distinctly lower $\mathrm{MgO}$ and $\mathrm{Cr}$ and higher $\mathrm{P}_{2} \mathrm{O}_{5}$ contents (table 2); these outcrops are assigned to the basalt of Sentinel Gap (Twfs $)$ of Beeson and others (1985) and Martin and others (2013).

\section{Rocks of the Boring Volcanic Field}

Volcanic eruptions in and near the map area ended after the Eagle Creek Formation was deposited and did not resume until the Pleistocene, when several, small, short-lived volcanoes developed. These small centers consist of cinder cones that mark vents for associated lava flows of olivine-phyric basalt, 
basaltic andesite, and low-SiO andesite (fig. 3). They are part of the Boring Volcanic Field (Evarts and others, 2009), a collection of several dozen monogenetic vents scattered throughout the region from Portland to Beacon Rock (Hodge, 1938; Treasher, 1942; Trimble, 1963; Allen, 1975; Tolan and Beeson, 1984). Products of eleven such centers have been identified in the Beacon Rock quadrangle based on field relations, petrography, geochemistry (table 3; fig. 11), paleomagnetic properties (table 5; fig. 12), and ${ }^{40} \mathrm{Ar} /{ }^{39} \mathrm{Ar}$ ages (table 4). They are distributed in two roughly north-south-oriented belts: one from Three Corner Rock to Beacon Rock and the other south of Hard Scramble Creek. Vents for eight units have been located (seven within the map area); vents for the other three have apparently been eroded, buried by younger volcanic rocks, or displaced by landslides.
Three Quaternary volcanic units in the map area erupted at about $1 \mathrm{Ma}$ (table 4): the medium-potassium basaltic andesites of Three Corner Rock (Qtcr), Woodward Creek (Qmwc), and Little Creek (Qmlc). The chemically similar basaltic andesite of Duncan Creek (Qmdc) is about 200 k.y. younger. All four units are notable for low $\mathrm{Ba} / \mathrm{Nb}$ (15-25), atypical of volcanic-arc magmas (Gill, 1981). Three Corner Rock (fig. 13) is a massive lava plug that fills the vent of a completely eroded scoria cone. The source for the Woodward Creek lavas, bisected by and well exposed in the high eastern headwall scarp of the Skamania Landslide Complex, consists of a plug partly encased in agglutinated scoria. Woodward Creek flows are notable for the presence of dark spheroidal pyroxene xenocrysts, some with reaction rinds of fine-grained olivine as large as $3 \mathrm{~mm}$ in diameter. The basaltic andesite of Little Creek is a flow remnant
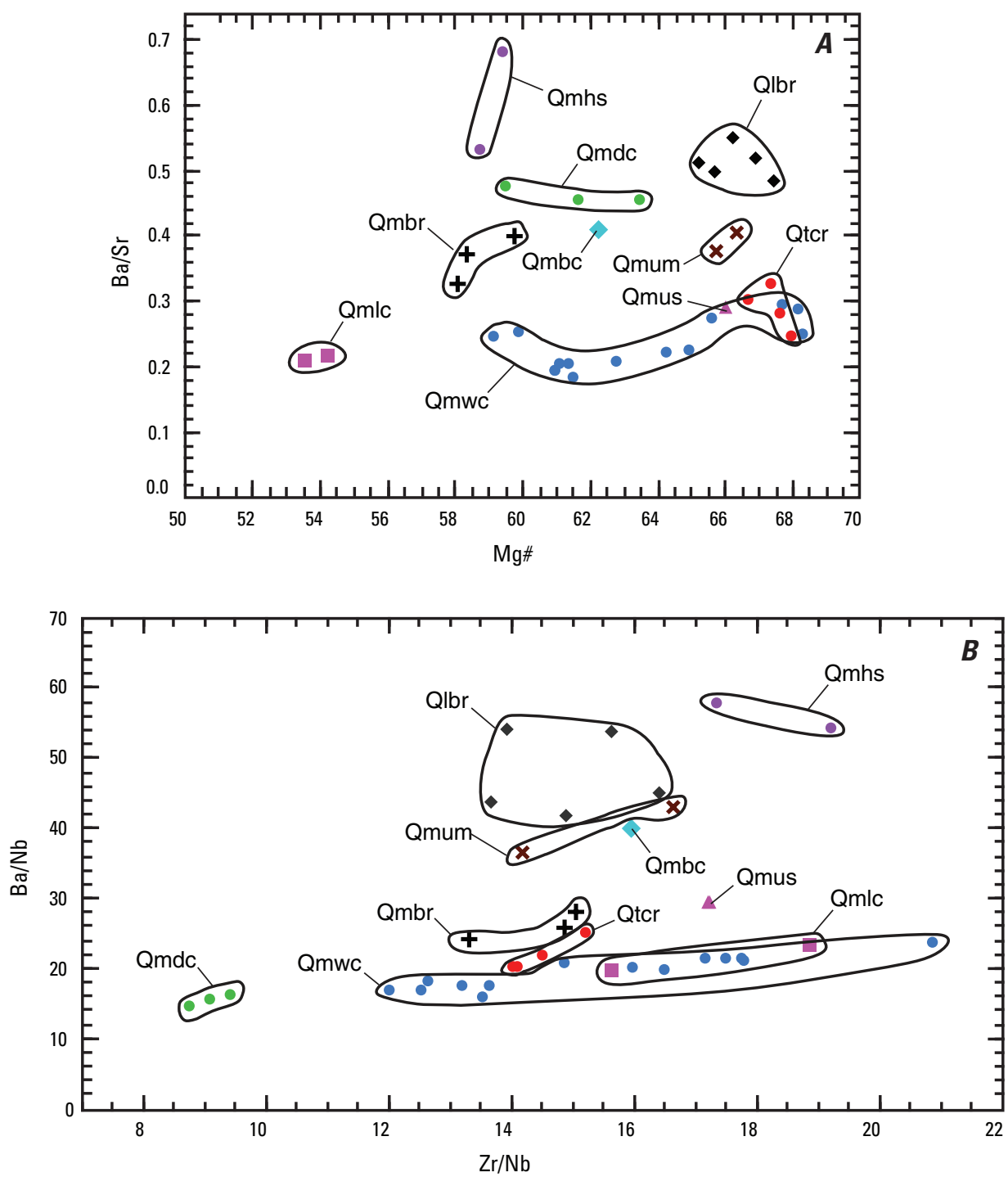

Figure 11. Selected chemical characteristics of Pleistocene volcanic and subvolcanic rocks in the Beacon Rock 7.5' quadrangle. $A, \mathrm{Ba} / \mathrm{Sr}$ versus $\mathrm{Mg} \#$ (atomic ratio $100 \mathrm{Mg} /\left(\mathrm{Mg}+\mathrm{Fe}^{2+}\right.$ ) with $\mathrm{Fe}^{2+}$ set to $\left.0.85 \times \mathrm{Fe}^{\text {totall }}\right) . B, \mathrm{Ba} / \mathrm{Nb}$ versus $\mathrm{Zr} / \mathrm{Nb}$. See Description of Map Units for unit identities. 


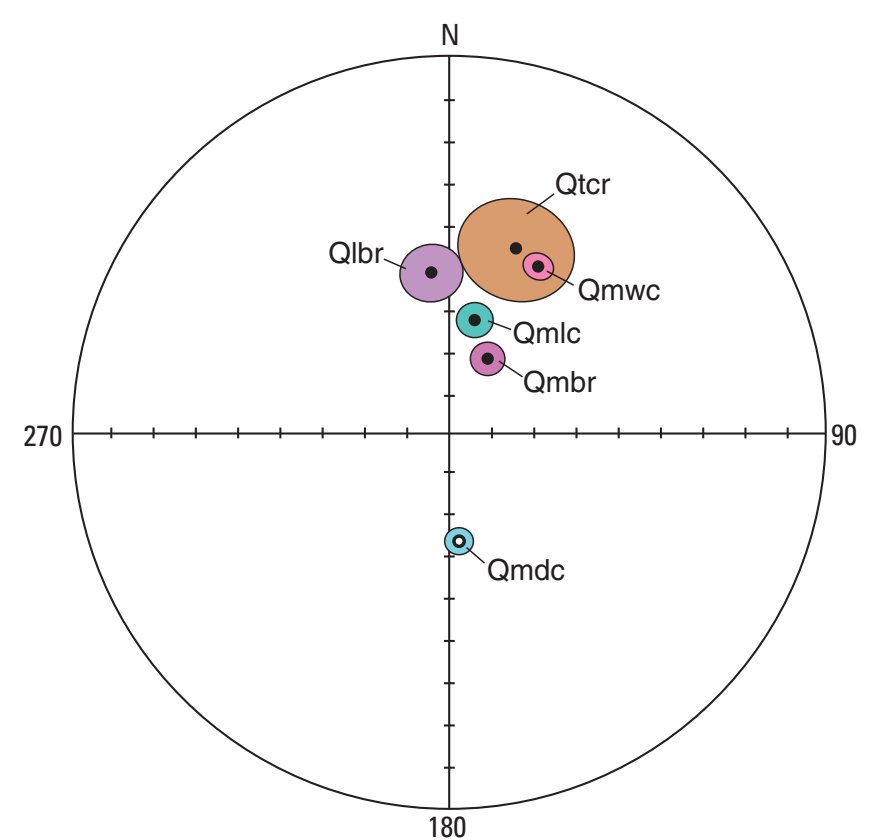

Figure 12. Paleomagnetic directions for Quaternary volcanic rocks in the Beacon Rock 7.5' quadrangle. Dots show lowerhemisphere (normal) directions. Open circles show upperhemisphere (reversed) directions. Thin lines outline areas of 95 percent confidence intervals. See Description of Map Units for unit identities.

banked against the east side of Hardy Ridge. It may have issued from the same vent as Woodward Creek. The Duncan Creek unit consists of several small flow remnants scattered along the top of the western scarp of the Skamania Landslide Complex. The location of its source is unknown but probably to the east in the area now underlain by landslide debris.

Most of the other Quaternary volcanic rocks in the map area are normally magnetized and were emplaced during the Bruhnes polarity chron. Little Beacon Rock, composed of coarse agglutinated scoria cut by irregular to tabular basalt intrusions, is the dissected core of a small volcano that generated a basalt flow (Qlbr) that overlies the Eagle Creek Formation to the northwest. It was active at $498 \pm 7 \mathrm{ka}$ (table 4). The elevation of the vent complex at Little Beacon Rock is about $250 \mathrm{~m}$ lower than the flow remnant, suggesting that the vent complex is a large slump block.

The Quaternary volcanic rocks west of McCloskey Creek are on the east edge of a short north-south cluster of volcanoes in the adjacent Bobs Mountain quadrangle (Evarts and others, 2009; R.C. Evarts, unpub. mapping). Two scoria cones mark the vents for a series of basaltic andesite flows that moved westward into the ancestral Washougal River. These flows, the basaltic andesite of Boyles Creek (Qmbc) and the basaltic andesite of Hard Scramble Creek (Qmhs), are distinguished by their relatively high contents of large-ion lithophile elements such as potassium, barium, and strontium (table 3; figs. 2, 10). ${ }^{40} \mathrm{Ar} /{ }^{39} \mathrm{Ar}$ age determinations for this unit in the adjacent Bobs Mountain quadrangle show that most of these eruptions occurred between $260 \mathrm{ka}$ and $290 \mathrm{ka}$ (Fleck and others, 2014). During this time span, the andesite of McCloskey Creek
(Qamc) issued from a dome at the south end of the McCloskey Creek cluster, about $1 \mathrm{~km}$ west of map area (R.C. Evarts, unpub. mapping). Two small mapped volcanic units, the basaltic andesite of upper McCloskey Creek (Qmum) and the basaltic andesite of upper Hard Scramble Creek (Qmus) have not been dated and their magnetic polarity is unknown. They underlie the other flow units in the McCloskey Creek cluster and differ chemically, with much lower $\mathrm{K}_{2} \mathrm{O}$ contents; they presumably record an older eruptive episode.

The youngest volcano in the map area, as well as in the entire Boring Volcanic Field, is the basaltic andesite of Beacon Rock (Qmbr). This 250-m-high monolith (see cover photograph) has long been recognized as the exhumed neck of an ancient volcano, presumably a cinder cone (Williams, 1916; Hodge, 1938; Hammond, 1980; Hammond and Korosec, 1983; Waters, 1973). Its $58-\mathrm{ka}{ }^{40} \mathrm{Ar} /{ }^{39} \mathrm{Ar}$ age is surprisingly young considering the normal decay rates of cinder cones (Wood, 1980). The explanation must be that the enclosing scoria deposits were completely washed away by the late Pleistocene cataclysmic floods (16,000-12,000 ${ }^{14} \mathrm{C}$ yrs. B.P.; Waitt, 1985, 1994; Atwater, 1986; Benito and O'Connor, 2003; Clague and others, 2003); the largest flood would have totally engulfed Beacon Rock (Benito and O'Connor, 2003).

\section{Alluvial and Mass-Wastage Deposits}

\section{Landslide and Talus Deposits}

One of the most prominent geologic features in the Beacon Rock quadrangle is the huge Skamania Landslide Complex (QIs), one of the largest of a series of landslides that extends nearly continuously along the north side of the Columbia River Gorge from Cape Horn to Dog Mountain (Palmer, 1977). The complex underlies about $35 \mathrm{~km}^{2}$ of the map area and consists of several geomorphic domains that apparently represent landslides of different ages. Like most of the large gorge slides, the Skamania complex is closely associated with exposures of the mechanically weak Eagle Creek Formation, particularly where overlain by thick sections of resistant Grande Ronde Basalt or Pleistocene lava flows (Hodge, 1938; Wise, 1970; Waters, 1973; Palmer, 1977; Hammond, 1980). At least some large slide events in the map area, however, evidently result from failure of water-saturated Eagle Creek strata without benefit of a superincumbent load. Waters (1973) emphasized the role of the thick saprolitic paleosol at the base of the Eagle Creek Formation in lubricating the Bonneville and other gorge slides, but, in the map area, failure planes appear to occur within as well as at the base of that unit. Periodic repairs to Washington State Route 14 and secondary roads, as well as the existence of incipient scarps behind the present landslide headwalls, testify to the active nature of parts of the slide complex.

Although the Skamania Landslide Complex is by far the largest, landslides are common in all areas underlain by the Eagle Creek Formation, such as those on the flanks of Hamilton Mountain, in upper Hamilton Creek, and in the headwaters of Deep Creek. Landslides are dispersed throughout 


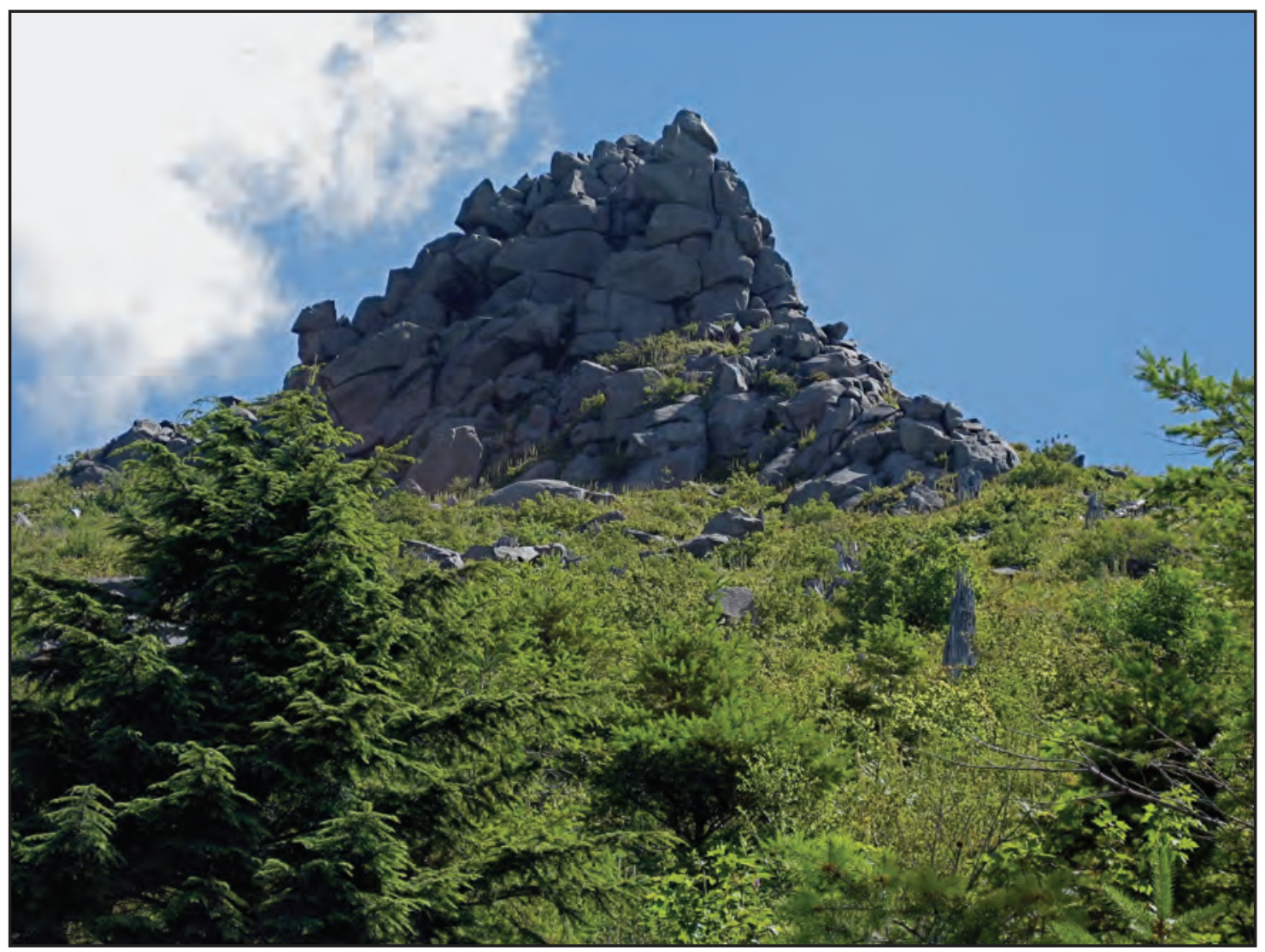

Figure 13. Three Corner Rock, a mass of basaltic andesite that occupied the throat of a now-eroded, approximately 1-Ma scoria cone. Barren rock outcrop is approximately $35 \mathrm{~m}$ tall.

areas underlain by older rocks as well, where they are generally associated with weathered or zeolitic volcaniclastic beds (Tt, Tvs), and the large landslide complex in Hamilton Creek valley formed where lavas flows of the Hamilton Creek rest on volcaniclastic rocks.

In addition to landslides formed by discrete failure events, talus deposits (Qt) created by slower incremental disintegration are common beneath cliffs composed chiefly of lava flows. In some places, the basal contacts of these units are buried for many kilometers by talus aprons; particularly extensive deposits are present at the base of the lava flows of Hamilton Creek in the northeast part of the quadrangle and beneath the Grande Ronde Basalt on the ridge west of Hardy Creek, the west slope of Hamilton Mountain, and Birkenfeld Mountain. Barren, post-landslide talus accumulations are also common at the base of steep landslide scarps.

\section{Holocene and Pleistocene Alluvium of Tributary Streams}

Most of the streams in the map area, including the Washougal River, occupy bedrock channels. The local accumulations of alluvium ( $\mathrm{Qa}$ ) along them consist predominantly of coarse sand and gravel. The alluvium in Hamilton Creek is exceptionally coarse, composed of boulders as large as $4 \mathrm{~m}$ in diameter that have weathered out of the Eagle Creek Formation.

The Washougal River in the map area is commonly flanked by strath terraces, with surfaces 2 to $5 \mathrm{~m}$ above the riverbed, that are mantled by as much as $6 \mathrm{~m}$ of cobble gravel (Qtdw $\mathrm{u}_{\mathrm{u}}$. These are little weathered and probably late Pleistocene or Holocene.

\section{Holocene Outburst-Flood Deposits}

The bench directly east of Beacon Rock is underlain by gravel inferred to have been deposited by outburst flooding from breaching of the Bonneville landslide, which blocked the Columbia River about $7 \mathrm{~km}$ upstream between A.D. 1425 and 1450 (O’Connor and Burns, 2009). Breaching was likely soon after damming, seemingly before A.D. 1482, judging from correlative outburst flood deposits downstream that underlie Mount St. Helens Kalama-age (A.D. 1479 or 1482) tephra.

\section{Structural Features}

Oligocene and early Miocene strata of the ancestral Cascade volcanic arc generally strike northeast and dip southeast in the map area. Dips within the three major unconformity-bounded packages exhibit a clear decrease with time (see cross sections $A-A^{\prime}$ and $B-B^{\prime}$ ). Abundant bedding 
measurements in the older, volcaniclastic-dominated strata give an average dip of about $25^{\circ}$. Although most deviations from this trend are attributable to localized deformation around intrusions, the flattening of dips in the northwestern part of the map reflects regional structure. Attitudes in the lava flows of Hamilton Creek are not as obvious because depositional contacts are rarely exposed and commonly irregular. Most measurements in this unit are from platy parting in lava flows, although variable attitudes of platy parting approximate original horizontal. These measurements are consistent with trends inferred from tracing individual flows within the unit; both trends indicate a regional dip of $5^{\circ}$ to $15^{\circ}$. Volcaniclastic beds of the Eagle Creek Formation are insufficiently exposed in the map area to obtain reliable attitudes, but pronounced platy parting in some lava flows dips south to southeast at less than $10^{\circ}$. These dips probably are primary and represent deposition on the surface of a south-sloping fan. Tracing of individual flows shows that the Grande Ronde Basalt strikes northwest and dips southwest at about $2^{\circ}$.

The differential dips displayed by the unconformitybounded rock packages indicate that the Oligocene strata were deformed prior to deposition of the lava flows of Hamilton Creek and that further mild southeasterly tilting took place prior to deposition of the Eagle Creek Formation. Late Oligocene strata in the Washougal area, approximately $6 \mathrm{~km}$ to the southwest, are oriented similarly to those in the Beacon Rock quadrangle (Evarts and others, 2013), but correlative beds in the poorly exposed intervening area instead strike west or southwest and exhibit shallower dips (R.C. Evarts, unpub. mapping), suggesting that these beds have been gently warped. Corresponding strata in the adjacent Bonneville Dam quadrangle strike west-northwest and dip south at low angles (Wise, 1961, 1970; R.C. Evarts, unpub. mapping), defining a shallow, southeast-plunging syncline that transects the northeastern part the map area. Broad open folds in pre-middle Miocene strata are typical of the Cascade Range of southwestern Washington (Wise, 1970; Hammond, 1980; Evarts and Swanson, 1994). These structures are large, and defining the trend of the fold axes requires mapping over areas much larger than a 7.5minute quadrangle. While most folding apparently occurred prior to emplacement of the lava flows of Hamilton Creek, tilting of those flows indicates that deformation continued into the early Miocene. Whether deformation continued during deposition of the Eagle Creek Formation and the Grande Ronde Basalt is uncertain, because dips in the Eagle Creek Formation are likely depositional. The onlap relation between the Columbia River Basalt Group and the Eagle Creek Formation may simply record emplacement of the massive basalt flows against an eroded, south-sloping, volcano flank that locally defined the north margin of the middle Miocene trans-arc lowland (Tolan and Beeson, 1984). The slight regional southwest tilting that affects the approximately 16-Ma Grande Ronde flows may relate to late uplift of the Cascade Range and (or) to mild, long-term, north-south compression as manifested in the Yakima fold belt (Beeson and others, 1989; Beeson and Tolan, 1990).

\section{Faults}

Only a few faults, with east-west, northeast, or northwest strikes, were mapped in the Beacon Rock quadrangle; all are steep and exhibit only minor vertical offsets. Those cutting only Oligocene rocks are marked by outcrops of sheared, brecciated, or altered rock; the displacements and lateral extents of these structures are highly uncertain. North of Hamilton Mountain, an east-west fault offsets Grande Ronde Basalt flows by about $25 \mathrm{~m}$. Faults in the upper McCloskey Creek area that juxtapose Columbia River Basalt Group flows against the Eagle Creek Formation appear to display larger displacements, but relief on the erosional unconformity between these two units makes it impossible to determine offsets with confidence. Some or all of these faults may be primarily strike-slip structures that accommodated the region-wide, clockwise, vertical-axis rotations determined from paleomagnetic studies (Beck and Burr, 1979; Wells and Heller, 1988; Hagstrum and others, 1999). No faults definitely cut Pleistocene volcanic rocks, thus none are known to have moved during the Quaternary.

\section{Geologic Resources}

Known geologic resources available in the Beacon Rock quadrangle are limited to nonmetallic industrial materials, chiefly aggregate for road construction and similar purposes. Small rock pits that provide material for logging roads in the northern part of the map area have been developed in various lava-flow and intrusive units. Road metal has also been obtained from large blocks of Grande Ronde Basalt in the Skamania Landslide complex.

\section{Geologic Evolution}

The ancestral Cascade volcanic arc initiated by $40 \mathrm{Ma}$ and was continuously active for 20 m.y. (Priest, 1990; Smith, 1993; Evarts and Swanson, 1994; Sherrod and Smith, 2000). Volcanic activity diminished significantly by the middle Miocene, coincident with eruption of flood basalt flows of the Columbia River Basalt Group. The oldest rocks in the Beacon Rock quadrangle record deposition within a regional intra-arc fluvial system that received episodic influxes of debris flows, pyroclastic flows, and lava flows from contemporaneous volcanic centers. These late Oligocene to early Miocene rocks exhibit minor to pervasive zeolite-facies metamorphism owing to shallow burial. Localized propylitic alteration in the Washougal River area probably reflects the existence of a shallow, unexposed intrusion of substantial size. Shortly after deposition, these strata were folded and partly eroded. At about $22 \mathrm{Ma}$, porphyritic mafic to intermediate lava flows (lava flows of Hamilton Creek) buried the eroded surface of the mildly tilted older strata. The preserved flows were probably deposited on the lower flanks of a volcanic edifice that was centered to the west, perhaps in the area of Hard Scramble Creek. These eruptions were followed by another period of nondeposition, lasting less than 2 m.y., when 
tilting of the strata continued and the Hamilton Creek volcano was deeply eroded. This erosional episode produced a surface with more than $100 \mathrm{~m}$ of topographic relief. A thick saprolitic soil profile developed on uplands between drainages. Between 20 and $19.5 \mathrm{Ma}$, this surface was buried by a south-sloping fan of coarse volcaniclastic debris (Eagle Creek Formation) probably derived from a field of andesitic and dacitic domes (Wise, 1970; Waters, 1973), including some located in the map area. Cessation of Eagle Creek volcanism marked the beginning of a long hiatus in arc volcanism in southern Washington and northern Oregon, when a 60-km-wide valley, the Cascade trans-arc lowland of Beeson and others (1989) and Beeson and Tolan (1990), developed through the ancestral Cascade Range. This lowland, which apparently existed during deposition of the Eagle Creek Formation (Beeson and others, 1989), was presumably occupied by an ancestral Columbia River.

Between 16.5 and 12 m.y. ago, massive flood-basalt flows entered western Oregon and Washington from the east through the trans-arc lowland. The route of the modern Columbia River in the map area closely coincides with the northern margin of the lowland, which is delineated by the unconformable contact between the Grande Ronde Basalt and Eagle Creek Formation. During a roughly 1.2-m.y. period, voluminous Grande Ronde Basalt and early Wanapum Basalt flows inundated much of the back-arc region, forming vast horizontal sheets that filled the subsiding trans-arc lowland (Beeson and others, 1989; Beeson and Tolan, 1990). The flows issued so rapidly that the ancestral Columbia River was rarely able to re-establish integrated drainage between eruptions. The discontinuous distribution and variable thickness of many Grande Ronde Basalt flows in the map area, however, indicate that they possess a more lobate form in this area at the margin of the flood-basalt field than they do in the Columbia Basin. Although the lobate character may reflect emplacement dynamics (Self and others, 1997; Thordarson and Self, 1998), we believe that inter-eruption erosion by streams along the northern margin of the trans-arc lowland was also a factor. Streams flowing out of highlands to the north were able to locally incise the flows and underlying Eagle Creek beds between emplacement events, as shown by the paleocanyon fill relations of an Ortley member flow that is well exposed on Hamilton Mountain (fig. 10). The existence of such streams implies that a major trunk river was localized by the edge of the flow field during intervals between basalt eruptions. Such a stream would have captured and transported away any sediment carried in from the north by tributary streams, thus accounting for the virtual absence of sedimentary interbeds within the nearby Columbia River Basalt Group. Observed banking of Grande Ronde Basalt flows against the Eagle Creek Formation demonstrates that flood-basalt flows flowed around a highland composed of andesitic to dacitic volcanic centers and did not completely blanket a low-elevation, low-relief Cascade Range in southernmost Washington at this time (Mackin and Cary, 1965; Mitchell and Montgomery, 2006).

The youngest Columbia River Basalt Group flows in the Beacon Rock quadrangle belong to the 15-Ma Frenchman Springs Member of the Wanapum Basalt. At least two later flood-basalt flows passed through the trans-arc lowland, routed by ancestral Columbia River canyons located south of the map area (Waters, 1973; Tolan, 1982; Tolan and Beeson, 1984).

Arc volcanism was renewed in the late Pliocene, about 4 to $3 \mathrm{Ma}$, as voluminous low-potassium tholeiite flows erupted in the Cascade Range south of the map area (Tolan and Beeson, 1984; Conrey and others, 1996a, 2004). This influx of basaltic volcanic material from the northern Oregon Cascade Range eventually forced the ancestral Columbia River northward to its present location (Tolan and Beeson, 1984).

Beginning about $2.6 \mathrm{Ma}$, mafic volcanic activity began to spread westward from the Cascade Range into the Portland Basin to form the Boring Volcanic Field (Treasher, 1942; Trimble, 1963; Allen, 1975; Conrey and others, 1996b; Evarts and others, 2009). Somewhat later, volcanism extended northward across the Columbia River (Hammond and Korosec, 1983), and several small, monogenetic eruptive centers formed in and adjacent to the map area within the past million years.

The modern Columbia River Gorge was formed as the Cascade Range axis arched upward during the past 2 m.y (Tolan and Beeson, 1984; Mustoe and Leopold, 2014). Tilting of Grande Ronde flows in the map area probably reflects a combination of this broad uplift superimposed on mild north-south compression that produced the Yakima fold belt (Reidel and others, 1989b, 2003).

The quadrangle lies well beyond the limits of Pleistocene glaciers emanating from the Cascade Range. No evidence exists for glacial ice in the Washougal drainage and no sediments of likely outwash origin are found in the map area. Cataclysmic outburst floods from glacial Lake Missoula coursed through the Columbia River Gorge in the latest Pleistocene (Bretz, 1925; Trimble, 1963; Allison, 1978; O’Connor and Baker, 1992; Waitt, 1994, 1996; Benito and O'Connor, 2003) and probably during earlier Pleistocene glaciations. Erosion of bedrock by the huge floods was probably limited, but they doubtless excavated significant quantities of talus and other unconsolidated debris from the base of gorge cliffs (Waitt, 1994), as well as removed the scoria deposits housing the Beacon Rock plug. In this reach of the Columbia River, the largest floods were about $240 \mathrm{~m}$ deep (Benito and O'Connor, 2003). Most of the large slope failures along the gorge, such as the Skamania Landslide Complex, appear to postdate the cataclysmic floods, but the floods may have played a role in promoting slides by preferentially eroding the weakly consolidated Eagle Creek Formation and thus undercutting and oversteepening slopes capped by lava flows.

\section{References Cited}

Allen, J.E., 1975, Volcanoes of the Portland area: Ore Bin, v. 37, p. $145-157$.

Allison, I.S., 1978, Late Pleistocene sediments and floods in the Willamette Valley: Ore Bin, v. 40, p. 193-202.

Atwater, B.F., 1986, Pleistocene glacial-lake deposits of the Sanpoil River Valley, northeastern Washington: U.S. Geological Survey Bulletin 1661, 39 p.

Baksi, A.K., 2013, Timing and duration of volcanism in the Columbia River Basalt Group-A review of existing 
radiometric data and new constraints on the age of the Steens through Wanapum Basalt extrusion, in Reidel, S.P., Camp, V.E., Ross, M.E., Wolff, J.A., Martin, B.S., Tolan, T.L., and Wells, R.E., eds., The Columbia River flood basalt province: Geological Society of America Special Paper 497, p. 67-85.

Barry, T.L., Kelley, S.P., Reidel, S.P., Camp. V.E., Self, S., Jarboe, N.A., Duncan, R.A., and Renne, P.R., 2013, Eruption chronology of the Columbia River Basalt Group, in Reidel, S.P., Camp, V.E., Ross, M.E., Wolff, J.A., Martin, B.S., Tolan, T.L., and Wells, R.E., eds., The Columbia River flood basalt province: Geological Society of America Special Paper 497, p. 45-666.

Barry, T.L., Self, S., Kelley, S.P., Reidel, S., Hooper, P., and Widdowson, M., 2010, New ${ }^{40} \mathrm{Ar} /{ }^{39} \mathrm{Ar}$ dating of the Grande Ronde lavas, Columbia River Basalts, USA-Implications for duration of flood basalt eruption episodes: Lithos, v. 118, p. 213-222.

Beck, M.E., Jr., and Burr, C.D., 1979, Paleomagnetism and tectonic significance of the Goble Volcanic Series, southwestern Washington: Geology, v. 7, p. 175-179.

Beeson, M.H., Fecht, K.R., Reidel, S.P., and Tolan, T.L., 1985, Regional correlations within the Frenchman Springs Member of the Columbia River Basalt Group-New insights into the middle Miocene tectonics of northwestern Oregon: Oregon Geology, v. 47, p. 87-96.

Beeson, M.H., and Tolan, T.L., 1990, The Columbia River Basalt Group in the Cascade Range-A middle Miocene reference datum for structural analysis: Journal of Geophysical Research, v. 96, p. 19,547-19,559.

Beeson, M.H., Tolan, T.L., and Anderson, J.L., 1989, The Columbia River Basalt Group in western Oregon; geologic structures and other factors that controlled flow emplacement patterns, in Reidel, S.P., and Hooper, P.R, eds., Volcanism and tectonism in the Columbia River floodbasalt province: Geologic Society of America Special Paper 239, p. 223-246.

Benito, G., and O'Connor, J.E., 2003, Number and size of last-glacial Missoula floods in the Columbia River valley between the Pasco Basin, Washington, and Portland, Oregon: Geological Society of America Bulletin, v. 115, p. 624-638.

Bretz, J H., 1925, The Spokane flood beyond the Channeled Scablands: Journal of Geology, v. 33, p. 97-115, 236-259.

Cas, R.A.F., and Wright, J.V., 1987, Volcanic successions; modern and ancient: London, Allen and Unwin, 528 p.

Chaney, R.W., 1918, The ecological significance of the Eagle Creek flora of the Columbia River Gorge: Journal of Geology, v. 26, no. 7, p. 577-592.

Chaney, R.W., 1944, Pliocene floras of California and Oregon, in Contributions to Paleontology: Carnegie Institution of Washington, Publication 553, $407 \mathrm{p}$.

Chaney, R.W., 1959, Miocene floras of the Columbia Plateau: Carnegie Institution of Washington, Publication 617, 237 p.

Clague, J.J., Barendregt, R., Enkin, R.J., and Foit, F.F., Jr., 2003, Paleomagnetic and tephra evidence for tens of Missoula floods in southern Washington: Geology, v. 31, p. 247-250.
Conrey, R.M., Sherrod, D.R., Uto, K., and Uchiumi, S., 1996a, Potassium-argon ages from Mount Hood area of Cascade Range, northern Oregon: Isochron West, no. 63, p. 10-20.

Conrey, R.M., Uto, K., Uchiumi, S., Beeson, M.H., Madin, I.P., Tolan, T.L., and Swanson, D.A., 1996b, Potassium-argon ages of Boring Lava, northwest Oregon and southwest Washington: Isochron West, no. 63, p. 3-9.

DeGraff, J.M., Long, P.E., and Aydin, A., 1989, Use of joint-growth directions and rock textures to infer thermal regime during solidification of basaltic lava flows: Journal of Volcanology and Geothermal Research, v. 38, p. 309-324.

du Bray, E.A., John, D.A., Sherrod, D.R., Evarts, R.C., Conrey, R.M., and Lexa, J., 2006, Geochemical database for volcanic rocks of the western Cascades, Washington, Oregon, and California: U.S. Geological Survey Data Series 155.

Evarts, R.C., Ashley, R.P., and Smith, J.G., 1987, Geology of the Mount St. Helens area-Record of discontinuous volcanic and plutonic activity in the Cascade arc of southern Washington: Journal of Geophysical Research, v. 92, p. 10, 155-10, 169.

Evarts, R.C., Conrey, R.M., Fleck, R.J., and Hagstrum, J.T., 2009, The Boring Volcanic Field of the PortlandVancouver area, Oregon and Washington-Tectonically anomalous forearc volcanism in an urban setting, in O'Connor, J.E., Dorsey, R.J., and Madin, I.P., eds., Volcanoes to vineyards - Geologic field trips through the dynamic landscape of the Pacific Northwest: Geological Society of America Field Guide 15, p. 253-270, doi:10.1130/2009.fl d015(13).

Evarts, R.C., O'Connor, J.E., and Tolan, T.L., 2013, Geologic map of the Washougal quadrangle, Clark County, Washington and Multnomah County, Oregon: U.S. Geological Survey Scientific Investigations Map 3257, scale 1:24,000, pamphlet 46 p., at http://pubs.usgs.gov/ $\operatorname{sim} / 3257$.

Evarts, R.C., and Swanson, D.A., 1994, Geologic transect across the Tertiary Cascade Range, southern Washington, in Swanson, D.A., and Haugerud, R.A., eds., Geologic field trips in the Pacific Northwest, 1994 Geological Society of America Meeting: Seattle, University of Washington Department of Geological Sciences, v. 2, p. 2H1-2H31.

Fisher, R., 1953, Dispersion on a sphere: Proceedings of the Royal Society of London, v. A217, p. 295-305.

Fiske, R.S., Hopson, C.A., and Waters, A.C., 1963, Geology of Mount Rainier National Park, Washington: U.S. Geological Survey Professional Paper 444, 93 p.

Fleck, R.J., Hagstrum, J.T., Calvert, A.T., and Evarts, R.C., 2014, Age, paleomagnetism, and interpretation of ${ }^{40} \mathrm{Ar} /{ }^{39} \mathrm{Ar}$ age spectra in lavas of the Boring volcanic field, Oregon and Washington, USA: Geosphere, v. 10, p. 1283-1314, doi:10.1130/GES00985.

Freundt, A., Wilson, C.J.N., and Carey, S.N., 2000, Ignimbrites and block-and-ash flow deposits, in Sigurdsson, H., ed., Encyclopedia of volcanoes: San Diego, Calif., Academic Press, p. 581-599. 
Gill, J.B., 1981, Orogenic andesites and plate tectonics: New York, Springer-Verlag, 390 p.

Gradstein, F.M., Ogg, J.G., Schmitz, M.D., and Ogg, eds., 2012, The geologic time scale 2012: Oxford, Elsevier, 1144 p.

Grant, A.R., 1969, Chemical and physical controls for base metal deposition in the Cascade Range, Washington: Washington Division of Mines and Geology Bulletin 58, 109 p.

Hagstrum, J.T., Swanson, D.A., and Evarts, R.C., 1999, Paleomagnetism of an east-west transect across the Cascade arc in southern Washington-Implications for regional tectonism: Journal of Geophysical Research, v. 104, p. $12,853-12,864$.

Hammond, P.E., 1980, Reconnaissance geologic map and cross sections of southern Washington Cascade Range, latitude $45^{\circ} 30^{\prime}-47^{\circ} 15^{\prime} \mathrm{N}$, longitude $120^{\circ} 45^{\prime}-122^{\circ} 22.5^{\prime}$ W: Portland, Oreg., Department of Earth Sciences Publications, Portland State University, scale 1:125,000, 2 sheets, pamphlet $31 \mathrm{p}$.

Hammond, P.E., and Korosec, M.A., 1983, Geochemical analyses, age dates, and flow-volume estimates for Quaternary volcanic rocks, southern Cascade Mountains, Washington: Washington Division of Geology and Earth Resources Open-File Report 83-13, 36 p.

Hodge, E.T., 1938, Geology of the lower Columbia River: Geological Society of America Bulletin, v. 49, p. 836-929.

Hooper, P.R., 1997, The Columbia River Flood Basalt Province-Current status, in Mahoney, J.J., and Coffin, M.F., eds., Large igneous provinces - Continental, oceanic, and planetary flood volcanism: American Geophysical Union Monograph 100, p. 1-27.

Hooper, P.R. 2000, Chemical discrimination of Columbia River basalt flows: Geochemistry, Geophysics, Geosystems, v. 1, 17 p., doi:10.1029/2000GC000040.

Johnson, D.M., Hooper, P.R., and Conrey, R.M., 1999, XRF analysis of rocks and minerals for major and trace elements on a single low dilution Li-tetraborate fused bead: Advances in X-ray Analysis, v. 41, p. 843-867.

Le Maitre, R.W., 2002, Igneous rocks-A classification and glossary of terms (2d ed.): Cambridge University Press, $236 \mathrm{p}$.

Long, P.E., and Wood, B.J., 1986, Structures, textures, and cooling histories of Columbia River basalt flows: Geological Society of America Bulletin, v. 97, p. 1144-1155.

Lowry, W.D., and Baldwin, E.M., 1952, Late Cenozoic geology of the lower Columbia River valley, Oregon and Washington: Geological Society of America Bulletin, v. 63, p. $1-24$.

Mackin, J.H., 1961, A stratigraphic section in the Yakima Basalt and the Ellensburg Formation in south-central Washington: Washington Division of Mines and Geology Report of Investigations $19,45 \mathrm{p}$.

Mackin, J.H., and Cary, A.S., 1965, Origin of Cascade landscapes: Washington division of Mines and Geology Information Circular 41, 35 p.

Mangan, M.T., Wright, T.L., Swanson, D.A., and Byerly, G.R., 1986, Regional correlation of Grande Ronde Basalt flows, Columbia River Basalt Group, Washington, Oregon, and
Idaho: Geological Society of America Bulletin, v. 97, p. $1300-1318$.

Martin, B.S., Tolan, T.L., and Reidel, S.P., 2013, Revisions to the stratigraphy and distribution of the Frenchman Springs Member, Wanapum Basalt, in Reidel, S.P., Camp, V.E., Ross, M.E., Wolff, J.A., Martin, B.S., Tolan, T.L., and Wells, R.E., eds., The Columbia River flood basalt province: Geological Society of America Special Paper 497, p. $155-179$.

McMillan, K., Long, P.E., and Cross, R.W., 1989, Vesiculation in Columbia River basalts, in Reidel, S.P., and Hooper, P.R, eds., Volcanism and tectonism in the Columbia River flood-basalt province: Geologic Society of America Special Paper 239, p. 157-167.

Mitchell, S.G., and Montgomery, D.R., 2006, Polygenetic topography of the Cascade Range, Washington State, USA: American Journal of Science, v. 306, p. 736-768.

Miyashiro, A., 1974, Volcanic rocks series in island arcs and active continental margins: American Journal of Science, v. 274, p. 321-355.

Mustoe, G.E., and Leopold, E.B., 2014, Paleobotanical evidence for the post-Miocene uplift of the Cascade Range: Canadian Journal of Earth Sciences, v. 51, p. 809-824.

O'Connor, J.E., and Baker, V.R., 1992, Magnitudes and implications of peak discharges from Glacial Lake Missoula: Geological Society of America Bulletin, v. 104, p. 267-279.

O’Connor, J.E., and Benito, G., 2009, Late Pleistocene Missoula Floods - 15,000-20,000 calendar years before present from radiocarbon dating [abs]: Geological Society of America Abstracts with Program, v. 41, no. 7, p. 169.

O'Connor, J.E., and Burns, S.F., 2009, Cataclysms and controversy-Aspects of the geomorphology of the Columbia River Gorge, in O'Connor, J.E., Dorsey, R.J., and Madin, I.P., eds., Volcanoes to vineyards - Geologic field trips through the dynamic landscape of the Pacific Northwest: Geological Society of America Field Guide 15, p. 237251, doi: 10.1130/2009.fl d015(12).

Palmer, L., 1977, Large landslides of the Columbia River Gorge, Oregon and Washington: Reviews in Engineering Geology, v. III, p. 69-83.

Pfaff, V.J., and Beeson, M.H., 1989, Miocene basalt near Astoria, Oregon; geophysical evidence for Columbia Plateau origin, in Reidel, S.P., and Hooper, P.R., eds., Volcanism and tectonism in the Columbia River floodbasalt province: Geological Society of America Special Paper 239, p. 143-156.

Phillips, W.M., comp., 1987, Geologic map of the Vancouver quadrangle, Washington: Washington Division of Geology and Earth Resources Open-File Report 87-10, scale 1:100,000, pamphlet $27 \mathrm{p}$.

Pierson, T.C., Evarts, R.C., and Bard, J.A., 2016, Landslides in the western Columbia River Gorge, Skamania County, Washington: U.S. Geological Survey Scientific Investigations Map 3358, scale 1:26,000, pamphlet $22 \mathrm{p}$.

Power, S.G., Field, C.W., Armstrong, R.L., and Harakal, J.E., 1981, K-Ar ages of plutonism and mineralization, western 
Cascades, Oregon and southern Washington: Isochron

West, no. 31, p. 27-29.

Priest, G.R., 1990, Volcanic and tectonic evolution of the Cascade volcanic arc, central Oregon: Journal of Geophysical Research, v. 95, p. 19,583-19,599.

Reidel, S.P., 1983, Stratigraphy and petrogenesis of the Grande Ronde Basalt from the deep canyon country of Washington, Oregon, and Idaho: Geological Society of America Bulletin, v. 94, p. 519-542.

Reidel, S.P., 1998, Emplacement of Columbia River flood basalt: Journal of Geophysical Research, v. 103, p. $27393-27410$.

Reidel, S.P., 2005, A lava flow without a source; the Cohassett Flow and its compositional components, Sentinel Bluffs Member, Columbia River Basalt Group: Journal of Geology, v. 113, p. 1-21.

Reidel, S.P., Camp, V.E., Tolan, T.L., and Martin, B.S., 2013, The Columbia River flood basalt province-Stratigraphy, areal extent, volume, and physical volcanology, in Reidel, S.P., Camp, V.E., Ross, M.E., Wolff, J.A., Martin, B.S., Tolan, T.L., and Wells, R.E., eds., The Columbia River flood basalt province: Geological Society of America Special Paper 497, p. 1-43.

Reidel, S.P., Fecht, K.R., Hagood, M.C., and Tolan, T.L., 1989b, The geologic evolution of the central Columbia Plateau, in Reidel, S.P., and Hooper, P.R, eds., Volcanism and tectonism in the Columbia River flood-basalt province: Geological Society of America Special Paper 239, p. 247-264.

Reidel, S.P., Martin, B.S., and Petcovic, H.L., 2003, The Columbia River flood basalts and the Yakima fold belt, in Swanson, T.W., ed., Western Cordillera and adjacent areas: Geological Society of America Field Guide 4, p.87-105.

Reidel, S.P., and Tolan, T.L, 2013, The Grande Ronde Basalt, Columbia River Basalt Group, in Reidel, S.P., Camp, V.E., Ross, M.E., Wolff, J.A., Martin, B.S., Tolan, T.L., and Wells, R.E., eds., The Columbia River flood basalt province: Geological Society of America Special Paper 497, p. $117-153$.

Reidel, S.P., Tolan, T.L., Hooper, P.R., Beeson, M.H., Fecht, K.R., Bentley, R.D., and Anderson, J.L., 1989a, The Grande Ronde Basalt, Columbia River Basalt Group; stratigraphic descriptions and correlations in Washington, Oregon, and Idaho, in Reidel, S.P., and Hooper, P.R, eds., Volcanism and tectonism in the Columbia River floodbasalt province: Geologic Society of America Special Paper 239, p. 21-53.

Roberts, A.E., 1958, Geology and coal resources of the Toledo-Castle Rock district, Cowlitz and Lewis Counties, Washington: U.S. Geological Survey Bulletin 1062, 71 p.

Self. S., Thordarson, T, and Keszthelyi, L., 1997, Emplacement of continental flood basalt lava flows, in Mahoney, J.J., and Coffin, M.F., eds., Large igneous provinces - Continental, oceanic, and planetary flood volcanism: American Geophysical Union Monograph 100, p. 381-410.

Sherrod, D.R., and Smith, J.G., 2000, Geologic map of upper Eocene to Holocene volcanic and related rocks of the Cascade Range, Oregon: U.S. Geological Survey Miscellaneous Investigations Map I-2569, scale 1:500,000, pamphlet $17 \mathrm{p}$.

Smith, J.G., 1993, Geologic map of upper Eocene to Holocene volcanic and related rocks in the Cascade Range, Washington: U.S. Geological Survey Miscellaneous Investigations Map I-2005, scale 1:500,000, pamphlet 19 p.

Swanson, D.A., Anderson, J.L., Bentley, R.D., Byerly, G.R., Camp, V.E., Gardner, J.N., and Wright, T.L., 1979a, Reconnaissance geologic map of the Columbia River Group in eastern Washington and northern Idaho: U.S. Geological Survey Open-File Report 79-1363, sheet 10 of 12, scale 1:250,000, pamphlet $26 \mathrm{p}$.

Swanson, D.A., Wright, T.L., Hooper, P.R., and Bentley, R.D., 1979b, Revisions in stratigraphic nomenclature of the Columbia River Basalt Group: U.S. Geological Survey Bulletin 1457-G, $59 \mathrm{p}$.

Thordarson, T., and Self, S., 1998, The Roza Member, Columbia River Basalt Group-A gigantic pahoehoe lava flow field formed by endogenous processes?: Journal of Geophysical Research, v. 103, p. 27,411-27,445.

Tolan, T.L., 1982, The stratigraphic relationships of the Columbia River Basalt Group in the lower Columbia River Gorge of Oregon and Washington: Portland, Oreg., Portland State University, M.S. thesis, 151 p.

Tolan, T.L., and Beeson, M.H., 1984, Intracanyon flows of the Columbia River Basalt Group in the lower Columbia River Gorge and their relationship to the Troutdale Formation: Geological Society of America Bulletin, v. 95, p. 463-477.

Tolan, T.L., Martin, B.S., Reidel, S.P., Anderson, J.L., Lindsey, K.A., and Burt, W., 2009, An introduction to the stratigraphy, structural geology, and hydrogeology of the Columbia River Flood-Basalt Province-A primer for the GSA Columbia River Basalt Group field trips, in O'Connor, J.E., Dorsey, R.J., and Madin, I.P., eds. Volcanoes to vineyards - Geologic field trips through the dynamic landscape of the Pacific Northwest: Geological Society of America Field Guide 15, p. 599-643, doi: 10.1130/2009.fl d015(28).

Tolan, T.L., Reidel, S.P., Beeson, M.H., Anderson, J.L., Fecht, K.R., and Swanson, D.A., 1989, Revisions to the estimates of the areal extent and volume of the Columbia River Basalt Group, in Reidel, S.P., and Hooper, P.R., eds., Volcanism and tectonism in the Columbia River floodbasalt province: Geologic Society of America Special Paper 239, p. 1-20.

Treasher, R.C., 1942, Geologic history of the Portland area: Oregon Department of Geology and Mineral Industries Short Paper 7, $17 \mathrm{p}$.

Trimble, D.E., 1963, Geology of Portland, Oregon, and adjacent areas: U.S. Geological Survey Bulletin 1119, 119 p., scale $1: 62,500$.

Vance, J.A., Clayton, G.A., Mattinson, J.M., and Naeser, C.W., 1987, Early and middle Cenozoic stratigraphy of the Mount Rainier-Tieton River area, southern Washington Cascades, in Schuster, E.J., ed., Selected papers on the geology of Washington: Washington Division of Geology and Earth Resources Bulletin 77, p. 269-290. 
Vye-Brown, C., Self, S., and Barry, T.L., 2013, Architecture and emplacement of flood basalt flow fields - Case studies from the Columbia River Basalt Group: Bulletin of Volcanology, v. 75, doi: 10.1007/s00445-013-0697-2.

Waitt, R.B., Jr., 1980, About 40 last-glacial Lake Missoula jökulhlaups through southern Washington: Journal of Geology, v. 88, p. 653-679.

Waitt, R.B., Jr., 1985, Case for periodic, colossal jökulhlaups from Pleistocene glacial Lake Missoula: Geological Society of America, v. 96, p. 1271-1286.

Waitt, R.B., Jr., 1994, Scores of gigantic, successively smaller Lake Missoula floods through channeled scabland and Columbia valley, in Swanson, D.A., and Haugerud, R.A., eds., Geologic field trips in the Pacific Northwest: Seattle, University of Washington Department of Geological Sciences, p. 1K1-1K88.

Waitt, R.B., Jr., 1996, Numerous colossal Missoula Floods through Columbia River Gorge and Portland-Vancouver basin [abs.]: Geological Society of America Abstracts with Program, v. 28, no. 5, p. 120-121.

Walsh, T.J., Korosec, M.A., Phillips, W.M., Logan, R.L., and Schasse, H.W., 1987, Geologic map of Washingtonsouthwest quadrant: Washington Division of Geology and Earth Resources Map GM-34, scale 1:250,000.

Wang, Y., and Chaker, A., 2004, Geologic hazards study for the Columbia River transportation corridor: Oregon Department of Geology and Mineral Industries Open-File Report O-04-08, 72 p.

Waters, A.C., 1973, The Columbia River Gorge-Basalt stratigraphy, ancient lava dams, and landslide dams, in Beaulieu, J.D., ed., Geologic field trips in northern Oregon and southern Washington: Oregon Department of Geology and Mineral Industries Bulletin 77, p. 133-162.

Wells, R.E., and Heller, P.L., 1988, The relative contribution of accretion, shear, and extension to Cenozoic tectonic rotation in the Pacific Northwest: Geological Society of America Bulletin, v. 100, p. 325-338.

Wells, R.E., Niem, A.R., Evarts, R.C., and Hagstrum, J.T., 2009, The Columbia River Basalt Group from the gorge to the sea, in O'Connor, J.E., Dorsey, R.J., and Madin, I.P., eds., Volcanoes to vineyards - Geologic field trips through the dynamic landscape of the Pacific Northwest: Geological Society of America Field Guide 15, p. 737-774, doi: 10.1130/2009.fl d015(32).

Wells, R.E., Simpson, R.W., Bentley, R.D., Beeson, M.H., Mangan, M.T., and Wright, T.L., 1989, Correlation of Miocene flows of the Columbia River Basalt Group from central Columbia River Plateau to the coast of Oregon and Washington, in Reidel, S.P., and Hooper, P.R, eds., Volcanism and tectonism in the Columbia River flood-basalt province: Geologic Society of America Special Paper 239, p. 113-129.

Wilkinson, W.D., Lowry, W.D., and Baldwin, E.M., 1946, Geology of the St. Helens quadrangle, Oregon: Oregon Department of Geology and Mineral Industries Bulletin 31, 39 p., scale 1:62,500.
Williams, I.A., 1916, The Columbia River Gorge-Its geologic history interpreted from the Historic Columbia River Highway: Oregon Bureau of Mines and Geology Mineral Resources of Oregon, v. 2, no. 3, 130 p. [2nd ed. published 1923, revised and reprinted by the Oregon Historical Society, 1991].

Wise, W.S., 1961, The geology of the Wind River area, Washington, and the stability relations of celadonite: Baltimore, Md., The Johns Hopkins University, Ph.D. dissertation, $257 \mathrm{p}$.

Wise, W.S., 1970, Cenozoic volcanism in the Cascade Mountains of southern Washington: Washington Division of Mines and Geology Bulletin 60, 45 p.

Wood, C.A., 1980, Morphometric analysis of cinder cone degradation: Journal of Volcanology and Geothermal Research, v. 8 , p. $137-160$. 
Appendix 1. ${ }^{40} \mathrm{Ar} /{ }^{39} \mathrm{Ar}$ incremental-heating data for samples from the Beacon Rock 7.5 ' quadrangle, Skamania County, Washington.

[See figure 18 (sheet 2) for sample locations and table 4 for unit assignments. Preferred age shown in bold; for plateau ages, steps used to calculate age shown in bold. Analytical techniques described in Fleck and others (2014). --, not determined; Wtd, weighted]

\begin{tabular}{|c|c|c|c|c|c|c|c|c|c|}
\hline Step $\left({ }^{\circ} \mathrm{C}\right)$ & $\mathbf{m o l}{ }^{39} \mathrm{Ar}$ & $\%{ }^{39} \mathrm{Ar}_{\mathrm{K}} \mathrm{ReI}$ & $\%{ }^{40} \mathrm{Ar}^{*}$ & ${ }^{40} \mathrm{Ar} /{ }^{39} \mathrm{Ar}$ & ${ }^{37} \mathrm{Ar} /{ }^{39} \mathrm{Ar}$ & ${ }^{36} \mathrm{Ar} /{ }^{39} \mathrm{Ar}$ & $\mathrm{K} / \mathrm{Ca}$ & $\mathrm{Cl} / \mathrm{K}$ & Age (Ma) \\
\hline \multicolumn{10}{|c|}{ 06BV-G633 Plagioclase IRR253-87 $\mathrm{J}=0.00211592$} \\
\hline 550 & $1.66216 \mathrm{E}-16$ & 8.1438 & 7.8075 & 58.13962 & 393.14141 & 0.28946 & 0.00099 & 0.065460 & $23.273 \pm 2.613$ \\
\hline 625 & $6.0442 \mathrm{E}-16$ & 29.6138 & 26.7119 & 18.95227 & 403.77861 & 0.15803 & 0.00095 & 0.026646 & $26.185 \pm 0.935$ \\
\hline 700 & $5.309 \mathrm{E}-16$ & 26.0117 & 44.8319 & 10.73890 & 395.60875 & 0.12882 & 0.00098 & 0.020453 & $24.729 \pm 0.941$ \\
\hline 775 & $2.92748 \mathrm{E}-16$ & 14.3433 & 38.7901 & 14.10144 & 386.48832 & 0.13545 & 0.00101 & 0.023488 & $27.844 \pm 1.295$ \\
\hline 850 & $1.17425 \mathrm{E}-16$ & 5.7533 & 18.1085 & 30.74764 & 373.55515 & 0.18795 & 0.00106 & 0.085942 & $28.019 \pm 2.796$ \\
\hline 925 & $1.01343 \mathrm{E}-16$ & 4.9654 & 19.2457 & 27.60780 & 153.86344 & 0.11773 & 0.00306 & 0.111912 & $22.441 \pm 2.727$ \\
\hline 1000 & $3.09423 \mathrm{E}-17$ & 1.5160 & 3.1920 & 88.37206 & 299.83922 & 0.37206 & 0.00140 & 10.785405 & $13.386 \pm 10.173$ \\
\hline 1100 & $4.86903 \mathrm{E}-17$ & 2.3856 & 13.1353 & 46.27887 & 342.75000 & 0.23029 & 0.00118 & 0.219630 & $29.770 \pm 5.399$ \\
\hline \multirow[t]{4}{*}{1250} & $1.4832 \mathrm{E}-16$ & 7.2670 & 29.7490 & 37.72643 & 321.79051 & 0.17817 & 0.00128 & 0.051954 & $53.634 \pm 2.217$ \\
\hline & \multirow{3}{*}{\multicolumn{2}{|c|}{ Intercept $=293.0 \pm 6.1$}} & & \multirow{3}{*}{\multicolumn{3}{|c|}{$\begin{array}{c}\text { Wtd Mean Plateau age (Ma) } \\
\text { Isochron age (Ma) } \\
\text { Integrated age (Ma) }\end{array}$}} & \multicolumn{2}{|c|}{ MSWD $=1.3$} & $25.780 \pm 0.548$ \\
\hline & & & & & & & MS & $=1.11$ & $26.166 \pm 1.014$ \\
\hline & & & & & & & & & $27.629 \pm 0.689$ \\
\hline \multicolumn{10}{|c|}{ 06BV-G700B Plagioclase IRR253-82 $\mathrm{J}=0.00221534$} \\
\hline 550 & $1.55961 \mathrm{E}-16$ & 0.6988 & 22.5447 & 16.71654 & 11.67381 & 0.04696 & 0.04460 & 0.00235 & $15.115 \pm 2.390$ \\
\hline 625 & $6.78876 \mathrm{E}-16$ & 3.0419 & 38.7861 & 15.34791 & 12.93587 & 0.03532 & 0.04021 & 0.00024 & $23.839 \pm 0.678$ \\
\hline 700 & $1.53969 \mathrm{E}-15$ & 6.8991 & 63.3062 & 9.77171 & 14.08902 & 0.01599 & 0.03689 & 0.00047 & $24.785 \pm 0.327$ \\
\hline 775 & $2.68925 \mathrm{E}-15$ & 12.0502 & 85.2486 & 7.08893 & 14.59076 & 0.00752 & 0.03561 & 0.00017 & $24.225 \pm 0.177$ \\
\hline 850 & 3.88034E-15 & 17.3872 & 92.8930 & 6.54898 & 14.71305 & 0.00559 & 0.03531 & 0.00025 & $24.387 \pm 0.125$ \\
\hline 925 & $4.27408 \mathrm{E}-15$ & 19.1516 & 93.7448 & 6.47058 & 14.57904 & 0.00535 & 0.03564 & 0.00007 & $24.315 \pm 0.128$ \\
\hline 1000 & $3.25692 \mathrm{E}-15$ & 14.5938 & 86.4504 & 6.98395 & 14.46110 & 0.00715 & 0.03594 & 0.00015 & $24.201 \pm 0.151$ \\
\hline 1075 & $2.59891 \mathrm{E}-15$ & 11.6454 & 92.5231 & 6.53369 & 14.27976 & 0.00555 & 0.03640 & 0.00009 & $24.228 \pm 0.177$ \\
\hline 1125 & $1.31179 \mathrm{E}-15$ & 5.8779 & 81.7519 & 7.42387 & 14.03922 & 0.00842 & 0.03703 & -0.00004 & $24.319 \pm 0.358$ \\
\hline 1200 & $8.69857 \mathrm{E}-16$ & 3.8977 & 68.7224 & 8.50482 & 12.55449 & 0.01242 & 0.04145 & 0.00056 & $23.402 \pm 0.501$ \\
\hline \multirow[t]{4}{*}{1400} & $1.06149 \mathrm{E}-15$ & 4.7564 & 56.8427 & 10.78381 & 14.52248 & 0.01972 & 0.03578 & 0.00081 & $24.569 \pm 0.415$ \\
\hline & \multirow{3}{*}{\multicolumn{2}{|c|}{ Intercept $=295.5 \pm 7.6$}} & & \multirow{3}{*}{\multicolumn{3}{|c|}{$\begin{array}{c}\text { Wtd Mean Plateau age (Ma) } \\
\text { Isochron age }(\mathrm{Ma}) \\
\text { Total gas age }(\mathrm{Ma})\end{array}$}} & \multirow{3}{*}{\multicolumn{2}{|c|}{$\begin{array}{l}\text { MSWD }=\mathbf{0 . 8 4} \\
\text { MSWD }=1.05\end{array}$}} & $24.300 \pm 0.112$ \\
\hline & & & & & & & & & $24.290 \pm 0.091$ \\
\hline & & & & & & & & & $24.220 \pm 0.068$ \\
\hline \multicolumn{10}{|c|}{ 06BV-G685 Plagioclase IRR253-81 $\mathrm{J}=0.00223501$} \\
\hline 550 & $2.6877 \mathrm{E}-16$ & 0.4102 & 6.0401 & 84.056142 & 8.84204 & 0.26970 & 0.05899 & 0.03162 & $20.476 \pm 3.427$ \\
\hline 625 & $8.59066 \mathrm{E}-16$ & 1.3113 & 69.2354 & 8.685938 & 8.95685 & 0.01147 & 0.05823 & 0.01378 & $24.230 \pm 0.447$ \\
\hline 700 & $1.98469 \mathrm{E}-15$ & 3.0294 & 86.1146 & 6.879232 & 9.19131 & 0.00573 & 0.05674 & 0.00402 & $23.874 \pm 0.204$ \\
\hline 775 & 3.69796E-15 & 5.6445 & 92.9978 & 6.417668 & 9.17245 & 0.00401 & 0.05686 & 0.00128 & $24.050 \pm 0.127$ \\
\hline 850 & $6.60559 \mathrm{E}-15$ & 10.0826 & 95.4603 & 6.240220 & 9.28752 & 0.00348 & 0.05615 & 0.00187 & $24.007 \pm 0.085$ \\
\hline 925 & $9.70208 \mathrm{E}-15$ & 14.8090 & 97.6099 & 6.123124 & 9.32759 & 0.00303 & 0.05591 & 0.00176 & $24.087 \pm 0.075$ \\
\hline 1000 & 8.88974E-15 & 13.5690 & 94.1271 & 6.304977 & 9.29239 & 0.00378 & 0.05612 & 0.04284 & $23.919 \pm 0.079$ \\
\hline 1075 & $1.05007 \mathrm{E}-14$ & 16.0280 & 97.7726 & 6.109434 & 9.18887 & 0.00296 & 0.05675 & 0.00100 & $24.072 \pm 0.075$ \\
\hline 1150 & $8.80687 \mathrm{E}-15$ & 13.4425 & 92.6957 & 6.450329 & 8.95849 & 0.00403 & 0.05822 & 0.00262 & $24.091 \pm 0.083$ \\
\hline 1250 & $1.23125 \mathrm{E}-14$ & 18.7934 & 84.1123 & 7.101271 & 8.80606 & 0.00621 & 0.05924 & 0.00183 & $24.064 \pm 0.080$ \\
\hline \multirow[t]{4}{*}{1400} & $1.88692 \mathrm{E}-15$ & 2.8801 & 82.1836 & 7.292973 & 9.00098 & 0.00684 & 0.05795 & 0.00144 & $24.150 \pm 0.210$ \\
\hline & & & & \multirow{3}{*}{\multicolumn{3}{|c|}{$\begin{array}{c}\text { Wtd Mean Plateau age (Ma) } \\
\text { Isochron age (Ma) } \\
\text { Total gas age (Ma) }\end{array}$}} & \multirow{3}{*}{\multicolumn{2}{|c|}{$\begin{array}{l}\text { MSWD }=\mathbf{0 . 5 8} \\
\text { MSWD }=0.89\end{array}$}} & $24.041 \pm 0.060$ \\
\hline & Intercept $=$ & $93.2 \pm 4.4$ & & & & & & & $24.046 \pm 0.061$ \\
\hline & & & & & & & & & $24.030 \pm 0.028$ \\
\hline
\end{tabular}


Appendix 1. ${ }^{40} \mathrm{Ar} /{ }^{39} \mathrm{Ar}$ incremental-heating data for samples from the Beacon Rock 7.5 ' quadrangle, Skamania County, Washington.Continued

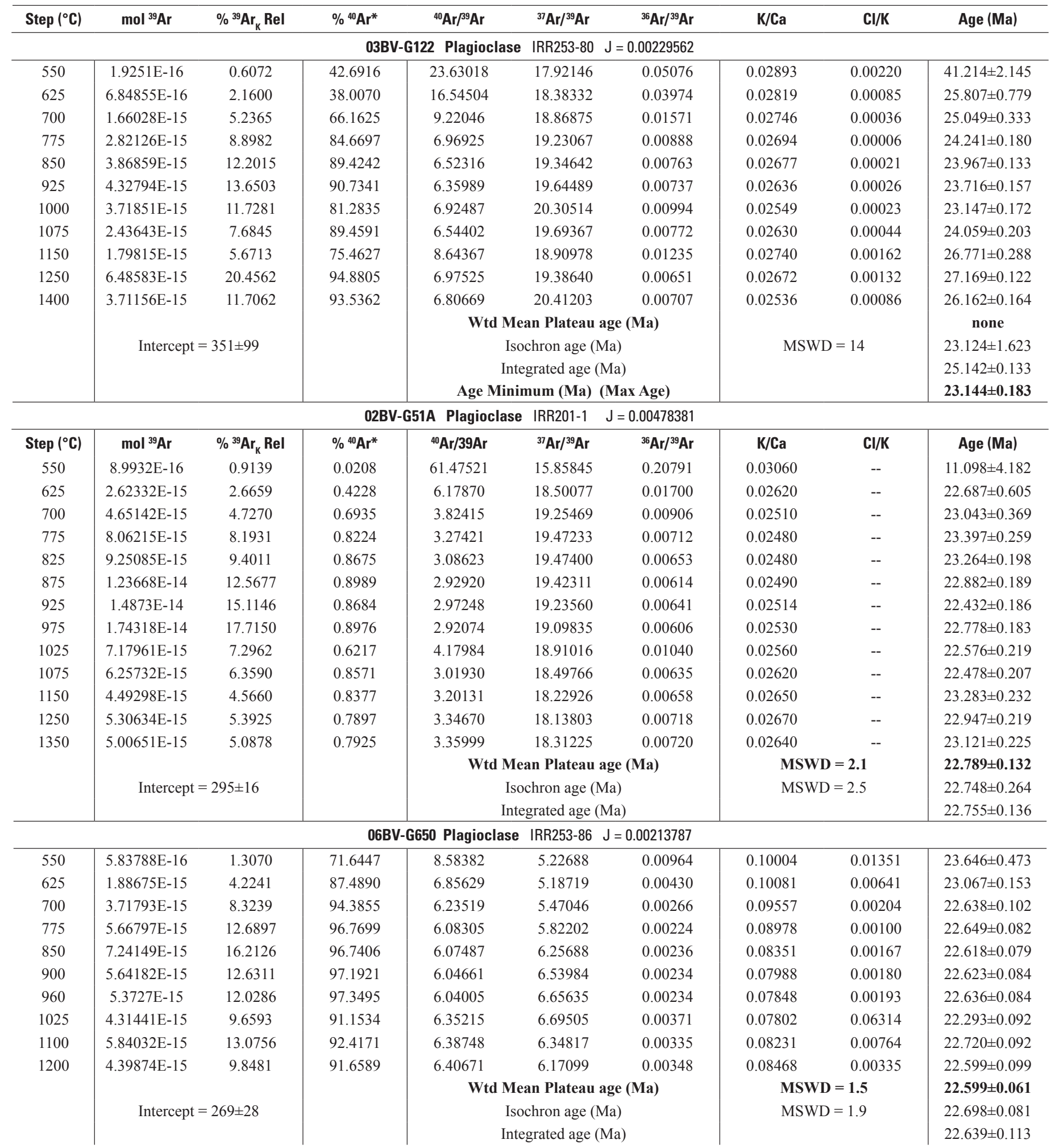


Appendix 1. ${ }^{40} \mathrm{Ar} /{ }^{39} \mathrm{Ar}$ incremental-heating data for samples from the Beacon Rock 7.5 ' quadrangle, Skamania County, WashingtonContinued.

\begin{tabular}{|c|c|c|c|c|c|c|c|c|c|}
\hline Step $\left({ }^{\circ} \mathrm{C}\right)$ & $\mathrm{mol}{ }^{39} \mathrm{Ar}$ & $\%{ }^{39} \mathrm{Ar}_{\mathrm{K}}$ Rel & $\%{ }^{40} \mathrm{Ar}^{*}$ & ${ }^{40} \mathrm{Ar} /{ }^{39} \mathrm{Ar}$ & ${ }^{37} \mathrm{Ar} /{ }^{39} \mathrm{Ar}$ & ${ }^{36} \mathrm{Ar} /{ }^{39} \mathrm{Ar}$ & $\mathrm{K} / \mathrm{Ca}$ & $\mathrm{Cl} / \mathrm{K}$ & Age (Ma) \\
\hline \multicolumn{10}{|c|}{ 05BV-G437 Plagioclase IRR253-83 $\mathrm{J}=0.00219861$} \\
\hline 550 & $2.49645 \mathrm{E}-16$ & 0.9304 & 0.3404 & 804.46108 & 21.28735 & 2.71891 & 0.02430 & 0.04428 & $10.982 \pm 27.580$ \\
\hline 575 & $3.45343 \mathrm{E}-16$ & 1.2879 & 1.8304 & 285.48357 & 20.24176 & 0.95394 & 0.02557 & 0.02154 & $20.887 \pm 7.179$ \\
\hline 600 & $2.86951 \mathrm{E}-16$ & 1.0698 & 68.3150 & 8.32630 & 20.68857 & 0.01457 & 0.02501 & 0.00965 & $22.731 \pm 1.048$ \\
\hline 650 & 7.17922E-16 & 2.6766 & 61.3218 & 9.23221 & 20.62020 & 0.01771 & 0.02510 & 0.00720 & $22.625 \pm 0.467$ \\
\hline 700 & $1.08275 \mathrm{E}-15$ & 4.0369 & 74.9164 & 7.41524 & 20.60276 & 0.01193 & 0.02512 & 0.00440 & $22.202 \pm 0.298$ \\
\hline 775 & $2.5131 \mathrm{E}-15$ & 9.3693 & 86.6183 & 6.33784 & 20.68135 & 0.00853 & 0.02502 & 0.00226 & $21.943 \pm 0.157$ \\
\hline 850 & $3.70591 \mathrm{E}-15$ & 13.8166 & 75.2990 & 7.30469 & 20.65020 & 0.01175 & 0.02506 & 0.00364 & $21.985 \pm 0.143$ \\
\hline 925 & $5.13166 \mathrm{E}-15$ & 19.1318 & 61.6434 & 8.93493 & 20.68155 & 0.01725 & 0.02502 & 0.00300 & $22.015 \pm 0.159$ \\
\hline 1000 & $3.52997 \mathrm{E}-15$ & 13.1615 & 84.3676 & 6.46038 & 20.55590 & 0.00904 & 0.02518 & 0.10450 & $21.785 \pm 0.143$ \\
\hline 1075 & $1.84136 \mathrm{E}-15$ & 6.8686 & 95.0882 & 5.76518 & 19.89296 & 0.00640 & 0.02603 & 0.00666 & $21.901 \pm 0.191$ \\
\hline 1150 & $1.41665 \mathrm{E}-15$ & 5.2886 & 92.0766 & 5.84356 & 18.69794 & 0.00667 & 0.02771 & 0.01480 & $21.481 \pm 0.191$ \\
\hline \multirow[t]{4}{*}{1250} & 5.99243E-15 & 22.3621 & 97.4560 & 5.66545 & 19.27165 & 0.00576 & 0.02688 & 0.00120 & $22.048 \pm 0.096$ \\
\hline & \multirow{3}{*}{\multicolumn{2}{|c|}{ Intercept $=295.0 \pm 1.3$}} & & \multicolumn{3}{|c|}{ Wtd Mean Plateau age (Ma) } & \multicolumn{2}{|c|}{ MSWD $=1.05$} & $21.943 \pm 0.056$ \\
\hline & & & & \multirow{2}{*}{\multicolumn{3}{|c|}{$\begin{array}{c}\text { Isochron age }(\mathrm{Ma}) \\
\text { Integrated age }(\mathrm{Ma})\end{array}$}} & \multirow{2}{*}{\multicolumn{2}{|c|}{ MSWD = 1.5}} & $21.907 \pm 0.142$ \\
\hline & & & & & & & & & $21.860 \pm 0.161$ \\
\hline \multicolumn{10}{|c|}{ 02BV-G52A Plagioclase IRR248-78 $\mathrm{J}=0.00276831$} \\
\hline 550 & $1.31094 \mathrm{E}-16$ & 0.0157 & -6.2312 & 17.63126 & 218.87917 & 0.12356 & 0.00205 & 0.25599 & $-6.337 \pm 4.510$ \\
\hline 625 & 5.67747E-16 & 0.0678 & 17.6943 & 13.31649 & 244.21438 & 0.10421 & 0.00180 & 0.26046 & $13.983 \pm 1.545$ \\
\hline 700 & $6.76344 \mathrm{E}-16$ & 0.0808 & 29.5569 & 9.71182 & 227.34679 & 0.08565 & 0.00196 & 0.15955 & $16.797 \pm 1.137$ \\
\hline 775 & $5.82629 \mathrm{E}-16$ & 0.0696 & 52.6237 & 6.87545 & 138.24987 & 0.04902 & 0.00345 & 0.04408 & $19.781 \pm 1.162$ \\
\hline 850 & 7.83399E-16 & 0.0936 & 57.0138 & 7.30261 & 88.69470 & 0.03500 & 0.00557 & 0.06671 & $21.956 \pm 0.844$ \\
\hline 925 & $1.44616 \mathrm{E}-15$ & 0.1727 & 71.5191 & 5.86323 & 113.89289 & 0.03694 & 0.00426 & 0.03409 & $22.509 \pm 0.592$ \\
\hline 1000 & $2.46518 \mathrm{E}-15$ & 0.2944 & 52.1640 & 7.49636 & 123.19778 & 0.04599 & 0.00391 & 0.46484 & $21.139 \pm 0.475$ \\
\hline 1100 & $5.28557 \mathrm{E}-16$ & 0.0631 & 33.1587 & 12.76443 & 65.50597 & 0.04684 & 0.00766 & 0.05160 & $21.962 \pm 1.257$ \\
\hline \multirow[t]{4}{*}{1250} & $1.19242 \mathrm{E}-15$ & 0.1424 & 40.8427 & 14.77957 & 95.49602 & 0.05581 & 0.00515 & 0.03929 & $31.898 \pm 0.779$ \\
\hline & \multirow{3}{*}{\multicolumn{2}{|c|}{ Intercept $=291 \pm 54$}} & & \multirow{2}{*}{\multicolumn{3}{|c|}{$\begin{array}{c}\text { Wtd Mean Plateau age (Ma) } \\
\text { Isochron age (Ma) }\end{array}$}} & \multirow{2}{*}{\multicolumn{2}{|c|}{$\begin{array}{l}\text { MSWD }=\mathbf{1 . 5} \\
\text { MSWD }=1.8\end{array}$}} & $21.592 \pm 0.314$ \\
\hline & & & & & & & & & $21.704 \pm 3.550$ \\
\hline & & & & $\begin{array}{l}\text { Total gas age } \\
\text { (Ma) }\end{array}$ & & $1.683 \pm 0.314$ & & & \\
\hline \multicolumn{10}{|c|}{ 04BV-G281A Plagioclase IRR248-79 $\mathrm{J}=0.00269623$} \\
\hline 550 & $7.78611 \mathrm{E}-16$ & 0.8048 & 63.8260 & 5.98304 & 6.06039 & 0.00897 & 0.08623 & 0.04601 & $18.294 \pm 0.614$ \\
\hline 625 & $3.70929 \mathrm{E}-15$ & 3.8341 & 74.5527 & 5.46825 & 6.72614 & 0.00653 & 0.07766 & 0.01794 & $19.533 \pm 0.181$ \\
\hline 700 & $8.5138 \mathrm{E}-15$ & 8.8003 & 92.3224 & 4.46980 & 7.21191 & 0.00311 & 0.07241 & 0.00445 & $19.776 \pm 0.100$ \\
\hline 775 & $1.27963 \mathrm{E}-14$ & 13.2270 & 97.1349 & 4.19702 & 7.45831 & 0.00243 & 0.07000 & 0.00168 & $19.542 \pm 0.076$ \\
\hline 850 & $1.6631 \mathrm{E}-14$ & 17.1907 & 95.9164 & 4.22814 & 7.52476 & 0.00262 & 0.06938 & 0.00278 & $19.441 \pm 0.072$ \\
\hline 925 & $1.80708 \mathrm{E}-14$ & 18.6789 & 97.5558 & 4.16115 & 7.58184 & 0.00240 & 0.06886 & 0.00243 & $19.461 \pm 0.069$ \\
\hline 1000 & $1.15855 \mathrm{E}-14$ & 11.9754 & 89.5435 & 4.53688 & 7.60745 & 0.00367 & 0.06862 & 0.10128 & $19.476 \pm 0.086$ \\
\hline 1100 & $9.29497 \mathrm{E}-15$ & 9.6078 & 94.9919 & 4.25909 & 7.43642 & 0.00274 & 0.07021 & 0.00426 & $19.394 \pm 0.090$ \\
\hline \multirow[t]{4}{*}{1250} & $1.53638 \mathrm{E}-14$ & 15.8809 & 91.4304 & 4.44880 & 7.15277 & 0.00323 & 0.07301 & 0.00669 & $19.494 \pm 0.078$ \\
\hline & & & & \multirow{3}{*}{\multicolumn{3}{|c|}{$\begin{array}{c}\text { Wtd Mean Plateau age (Ma) } \\
\text { Isochron age (Ma) } \\
\text { Integrated age (Ma) }\end{array}$}} & \multirow{3}{*}{\multicolumn{2}{|c|}{$\begin{array}{l}\text { MSWD }=\mathbf{1 . 3} \\
\text { MSWD }=1.9\end{array}$}} & $19.501 \pm 0.049$ \\
\hline & Intercep & $294 \pm 14$ & & & & & & & $19.493 \pm 0.061$ \\
\hline & & & & & & & & & $19.490 \pm 0.101$ \\
\hline
\end{tabular}


Appendix 1. ${ }^{40} \mathrm{Ar} /{ }^{39} \mathrm{Ar}$ incremental-heating data for samples from the Beacon Rock 7.5 ' quadrangle, Skamania County, WashingtonContinued.

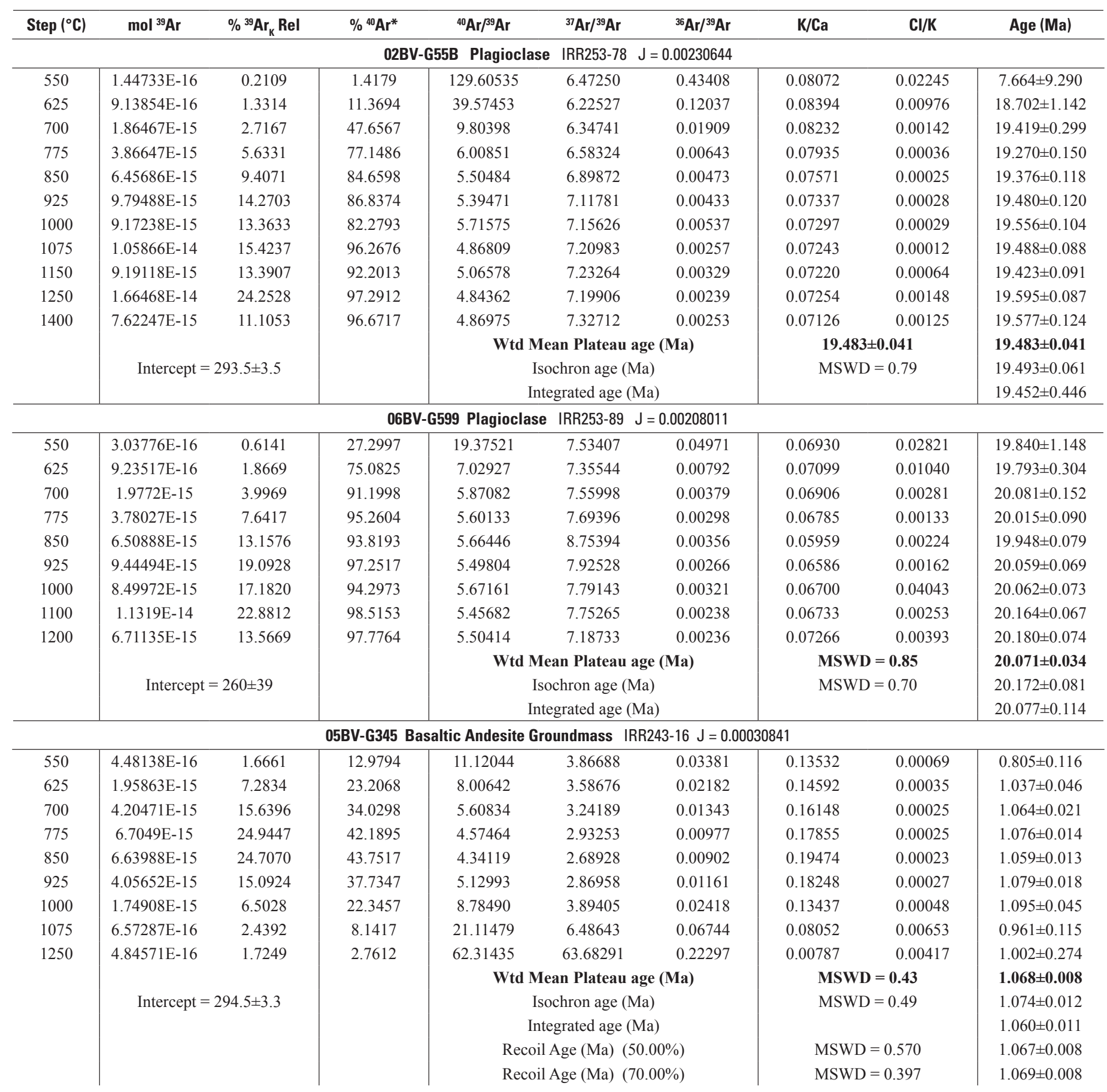


Appendix 1. ${ }^{40} \mathrm{Ar} /{ }^{39} \mathrm{Ar}$ incremental-heating data for samples from the Beacon Rock 7.5' quadrangle, Skamania County, Washington.Continued

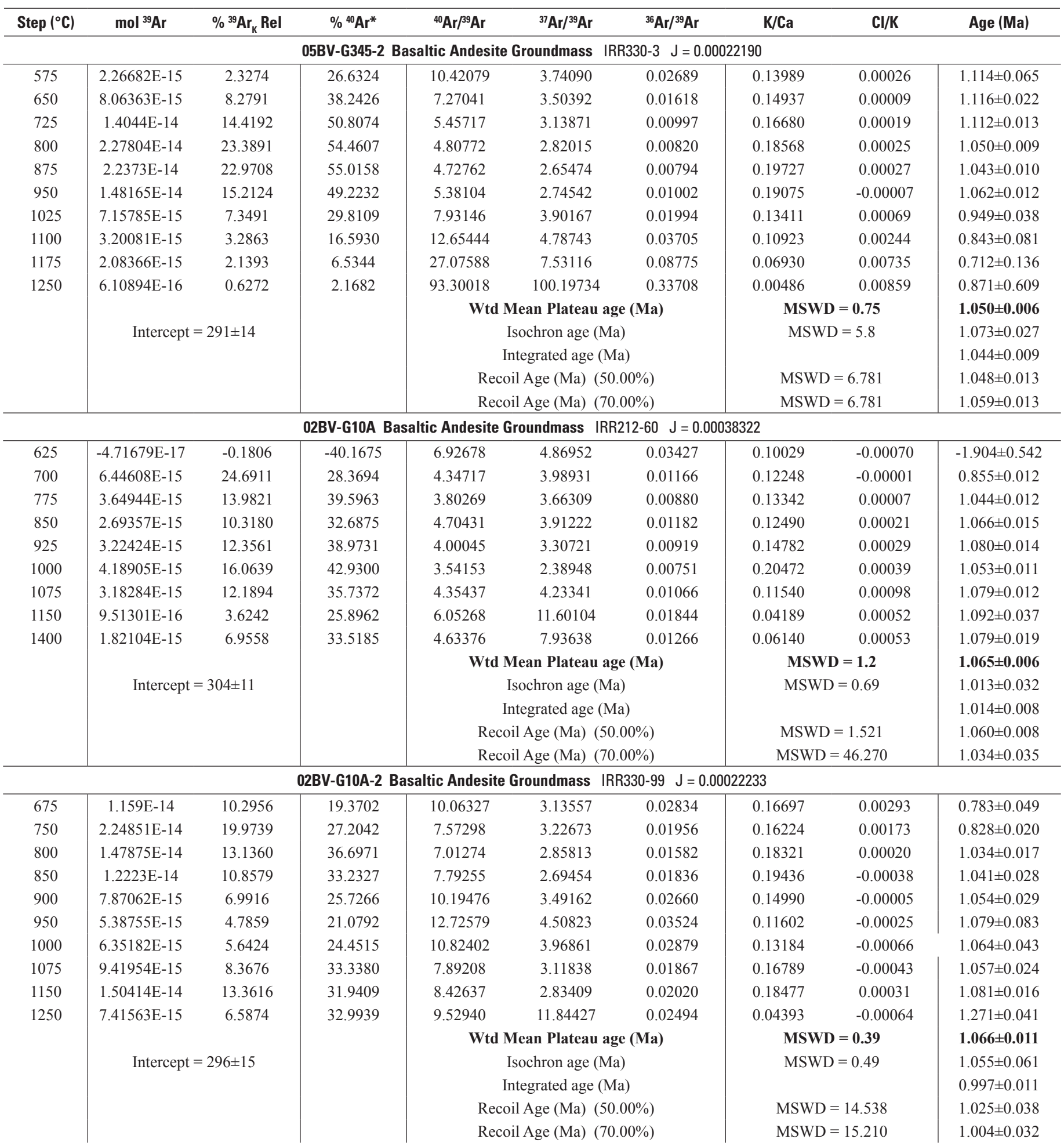


Appendix 1. ${ }^{40} \mathrm{Ar} /{ }^{39} \mathrm{Ar}$ incremental-heating data for samples from the Beacon Rock 7.5' quadrangle, Skamania County, Washington.Continued

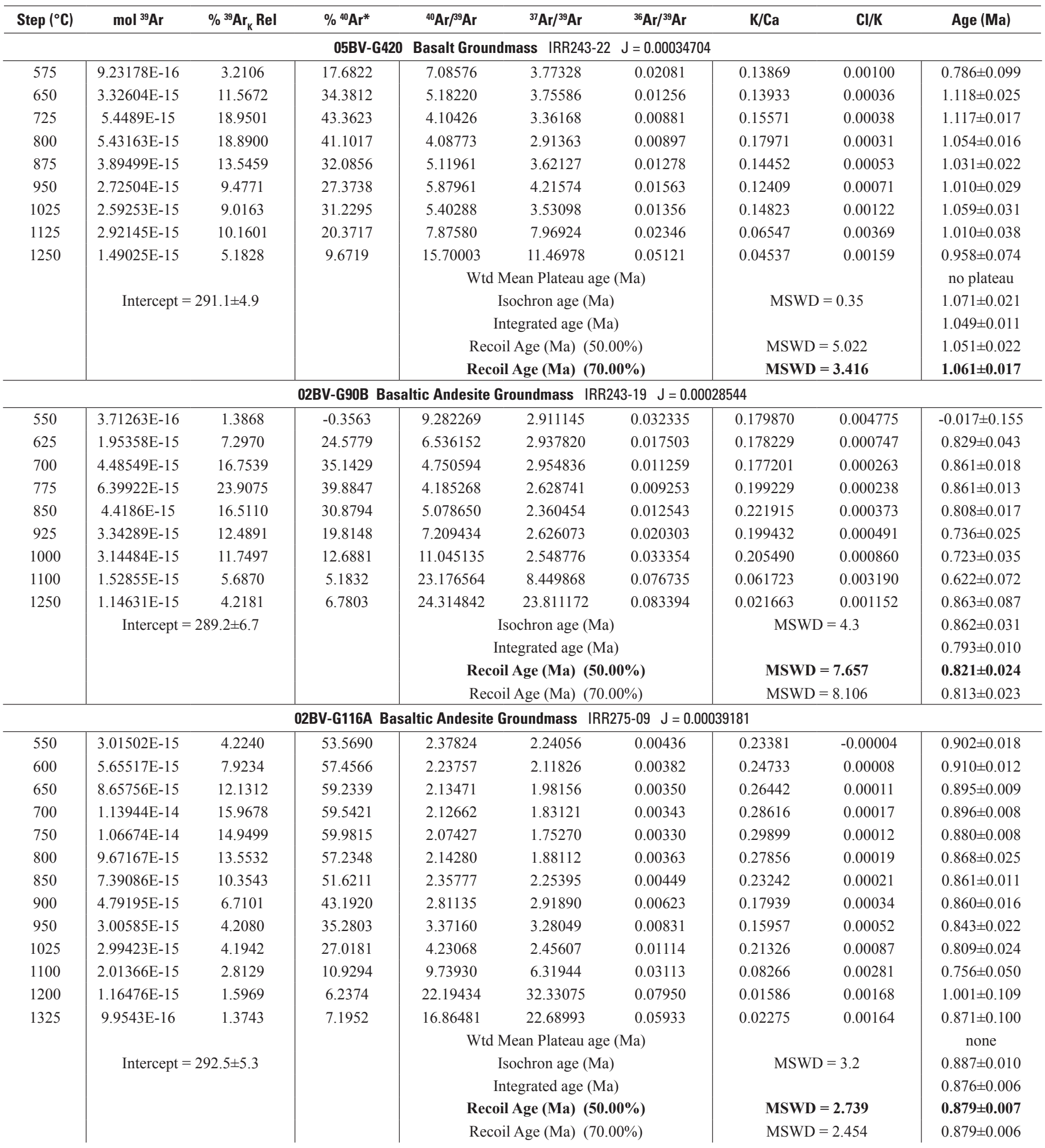


Appendix 1. ${ }^{40} \mathrm{Ar} /{ }^{39} \mathrm{Ar}$ incremental-heating data for samples from the Beacon Rock 7.5 ' quadrangle, Skamania County, Washington.Continued.

\begin{tabular}{|c|c|c|c|c|c|c|c|c|c|}
\hline Step $\left({ }^{\circ} \mathrm{C}\right)$ & $\mathrm{mol}^{39} \mathrm{Ar}$ & $\%{ }^{39} \mathrm{Ar}_{\mathrm{K}}$ Rel & $\%{ }^{40} \mathrm{Ar}^{*}$ & ${ }^{40} \mathrm{Ar} /{ }^{39} \mathrm{Ar}$ & ${ }^{37} \mathrm{Ar} /{ }^{39} \mathrm{Ar}$ & ${ }^{36} \mathrm{Ar} /{ }^{39} \mathrm{Ar}$ & $\mathrm{K} / \mathrm{Ca}$ & $\mathrm{Cl} / \mathrm{K}$ & Age (Ma) \\
\hline \multicolumn{10}{|c|}{ QV01-36 Basaltic Andesite Groundmass $\quad$ IRR189-A-6 J $\quad 0.00035207$} \\
\hline 550 & $-1.40209 \mathrm{E}-18$ & -0.0014 & -0.0274 & 25.98126 & 4.20709 & 0.09151 & 0.11612 & -- & $-0.447 \pm 0.112$ \\
\hline 625 & $1.03219 \mathrm{E}-14$ & 10.6346 & 0.0684 & 11.02339 & 3.51251 & 0.03574 & 0.13916 & -- & $0.480 \pm 0.028$ \\
\hline 700 & $1.46348 \mathrm{E}-14$ & 15.0782 & 0.1199 & 6.74436 & 3.01406 & 0.02093 & 0.16223 & -- & $0.514 \pm 0.018$ \\
\hline 775 & $1.92054 \mathrm{E}-14$ & 19.7873 & 0.1393 & 5.69057 & 2.65258 & 0.01732 & 0.18438 & -- & $0.504 \pm 0.015$ \\
\hline 850 & $1.75851 \mathrm{E}-14$ & 18.1178 & 0.1434 & 5.69740 & 2.51035 & 0.01722 & 0.19485 & -- & $0.519 \pm 0.015$ \\
\hline 1050 & $5.89761 \mathrm{E}-15$ & 6.0763 & 0.0711 & 10.33048 & 2.46145 & 0.03317 & 0.19872 & -- & $0.468 \pm 0.031$ \\
\hline 1100 & $3.05759 \mathrm{E}-15$ & 3.1502 & 0.0441 & 16.91182 & 6.60017 & 0.05656 & 0.07389 & -- & $0.476 \pm 0.056$ \\
\hline 1200 & $1.88502 \mathrm{E}-15$ & 1.9421 & 0.0121 & 25.59089 & 32.60441 & 0.09472 & 0.01468 & -- & $0.201 \pm 0.104$ \\
\hline \multirow[t]{2}{*}{1400} & $1.05831 \mathrm{E}-15$ & 1.090371075 & 0.02484819 & 35.17061 & 25.36495 & 0.12319 & 0.01897 & -- & $0.565 \pm 0.146$ \\
\hline & \multicolumn{3}{|c|}{ Intercept $=292.3 \pm 2.7$} & \multicolumn{3}{|c|}{ Wtd Mean Plateau age (Ma) } & \multicolumn{2}{|c|}{ MSWD $=1.2$} & $0.498 \pm 0.007$ \\
\hline \multicolumn{10}{|c|}{ QV98-17 Basaltic Andesite Whole Rock IRRCLX-B-21 J = 0.00040588 } \\
\hline 600 & $2.29479 \mathrm{E}-16$ & 0.4048 & -0.1234 & 25.14080 & 3.58134 & 0.09659 & 0.13647 & -- & $-2.248 \pm 0.541$ \\
\hline 675 & $3.88096 \mathrm{E}-15$ & 6.8462 & 0.0146 & 7.99321 & 2.94377 & 0.02748 & 0.16611 & -- & $0.085 \pm 0.039$ \\
\hline 750 & $5.22847 \mathrm{E}-15$ & 9.2233 & 0.0236 & 2.48434 & 2.70277 & 0.00897 & 0.18095 & -- & $0.043 \pm 0.025$ \\
\hline 825 & $1.00268 \mathrm{E}-14$ & 17.6878 & 0.0495 & 1.73347 & 2.64366 & 0.00632 & 0.18500 & -- & $0.063 \pm 0.014$ \\
\hline 900 & $1.43362 \mathrm{E}-14$ & 25.2899 & 0.0606 & 1.53575 & 2.51051 & 0.00559 & 0.19483 & -- & $0.068 \pm 0.011$ \\
\hline 975 & $1.02077 \mathrm{E}-14$ & 18.0070 & 0.0208 & 1.57335 & 2.53788 & 0.00593 & 0.19273 & -- & $0.023 \pm 0.014$ \\
\hline 1060 & $6.27121 \mathrm{E}-15$ & 11.0628 & 0.0443 & 2.52663 & 3.10422 & 0.00904 & 0.15750 & -- & $0.082 \pm 0.021$ \\
\hline 1160 & $4.03186 \mathrm{E}-15$ & 7.1124 & 0.0216 & 3.89190 & 3.64973 & 0.01391 & 0.13391 & -- & $0.062 \pm 0.033$ \\
\hline 1350 & $2.47487 \mathrm{E}-15$ & 4.3658 & -0.0120 & 7.63098 & 22.57346 & 0.03248 & 0.02136 & -- & $-0.067 \pm 0.069$ \\
\hline 600 & $2.27127 \mathrm{E}-15$ & 1.83507 & 0.01214 & 15.93179 & 3.41456 & 0.05422 & 0.14316 & -- & $0.130 \pm 0.068$ \\
\hline 675 & $1.43754 \mathrm{E}-14$ & 11.61457 & 0.04967 & 3.61449 & 2.83720 & 0.01242 & 0.17236 & -- & $0.121 \pm 0.013$ \\
\hline 750 & $1.15155 \mathrm{E}-14$ & 9.30391 & 0.09368 & 1.92075 & 2.68445 & 0.00665 & 0.18219 & -- & $0.121 \pm 0.013$ \\
\hline 825 & 3.25922E-14 & 26.33280 & 0.08651 & 1.56232 & 2.57505 & 0.00555 & 0.18994 & -- & $0.090 \pm 0.007$ \\
\hline 900 & $2.40757 \mathrm{E}-14$ & 19.45196 & 0.09182 & 1.29600 & 2.50179 & 0.00469 & 0.19551 & -- & $0.080 \pm 0.008$ \\
\hline 975 & $1.65967 \mathrm{E}-14$ & 13.40924 & 0.09130 & 1.43477 & 2.79139 & 0.00520 & 0.17519 & -- & $0.088 \pm 0.010$ \\
\hline 1050 & $9.60201 \mathrm{E}-15$ & 7.75793 & 0.05777 & 2.03125 & 3.85942 & 0.00756 & 0.12662 & -- & $0.079 \pm 0.016$ \\
\hline 1100 & $5.4576 \mathrm{E}-15$ & 4.40946 & 0.01845 & 3.62588 & 3.57889 & 0.01305 & 0.13657 & -- & $0.045 \pm 0.025$ \\
\hline 1200 & 4.99987E-15 & 4.03964 & 0.03473 & 4.63396 & 10.09875 & 0.01797 & 0.04817 & -- & $0.109 \pm 0.033$ \\
\hline 1400 & $1.94596 \mathrm{E}-15$ & 1.57224 & 0.06300 & 8.10564 & 27.27211 & 0.03337 & 0.01762 & -- & $0.349 \pm 0.084$ \\
\hline & & & & Wtc & an Plateau & Мa) & MS & & $0.084 \pm 0.005$ \\
\hline & Intercept $=$ & $298 \pm 19$ & & & chron age ( & & MSI & & $0.079 \pm 0.030$ \\
\hline & & & & & grated age ( & & & & $0.092 \pm 0.004$ \\
\hline & & & & & Age (Ma) & & MSV & & $0.086 \pm 0.005$ \\
\hline & & & & & Age (Ma) (7 & & MSV & & $0.090 \pm 0.006$ \\
\hline
\end{tabular}


Appendix 1. ${ }^{40} \mathrm{Ar} /{ }^{39} \mathrm{Ar}$ incremental-heating data for samples from the Beacon Rock 7.5' quadrangle, Skamania County, Washington.Continued.

\begin{tabular}{|c|c|c|c|c|c|c|c|c|c|}
\hline Step $\left({ }^{\circ} \mathbf{C}\right)$ & mol ${ }^{39} \mathrm{Ar}$ & $\%{ }^{39} \mathrm{Ar}_{\mathrm{K}} \mathrm{Rel}$ & $\%{ }^{40} \mathrm{Ar}^{*}$ & ${ }^{40} \mathrm{Ar} /{ }^{39} \mathrm{Ar}$ & ${ }^{37} \mathrm{Ar} /{ }^{39} \mathrm{Ar}$ & ${ }^{36} \mathrm{Ar} /{ }^{39} \mathrm{Ar}$ & K/Ca & $\mathrm{Cl} / \mathrm{K}$ & Age (Ma) \\
\hline \multicolumn{10}{|c|}{ QV01-35B Basaltic Andesite Groundmass IRR203-8 $\quad J=0.00042913$} \\
\hline 550 & $1.2883 \mathrm{E}-15$ & 1.8117 & -0.0365 & 12.39052 & 3.27998 & 0.04438 & 0.14905 & -- & $-0.346 \pm 0.232$ \\
\hline 625 & $8.78007 \mathrm{E}-15$ & 12.3471 & 0.0194 & 3.78270 & 3.14988 & 0.01344 & 0.15522 & -- & $0.057 \pm 0.037$ \\
\hline 700 & $1.35659 \mathrm{E}-14$ & 19.0772 & 0.0250 & 2.15958 & 2.63919 & 0.00787 & 0.18532 & -- & $0.042 \pm 0.013$ \\
\hline 775 & $1.97302 \mathrm{E}-14$ & 27.7458 & 0.0456 & 1.80305 & 2.39012 & 0.00650 & 0.20467 & -- & $0.064 \pm 0.010$ \\
\hline 840 & $1.24489 \mathrm{E}-14$ & 17.5065 & 0.0391 & 2.04524 & 2.79654 & 0.00744 & 0.17487 & -- & $0.062 \pm 0.014$ \\
\hline 900 & $6.30539 \mathrm{E}-15$ & 8.8670 & 0.0243 & 3.01532 & 4.03227 & 0.01109 & 0.12117 & -- & $0.057 \pm 0.024$ \\
\hline 960 & $3.56462 \mathrm{E}-15$ & 5.0128 & 0.0352 & 4.69351 & 5.14368 & 0.01677 & 0.09492 & -- & $0.129 \pm 0.041$ \\
\hline 1025 & $3.14426 \mathrm{E}-15$ & 4.4217 & 0.0069 & 7.97078 & 4.18617 & 0.02796 & 0.11671 & -- & $0.043 \pm 0.049$ \\
\hline 1100 & $2.07033 \mathrm{E}-15$ & 2.9114 & -0.0029 & 27.31662 & 21.07084 & 0.09863 & 0.02291 & -- & $-0.062 \pm 0.108$ \\
\hline \multirow[t]{6}{*}{1200} & $2.12532 \mathrm{E}-16$ & 0.2989 & -0.0115 & 93.13997 & 34.82139 & 0.32861 & 0.01373 & -- & $-0.84 \pm 0.696$ \\
\hline & & & & \multicolumn{3}{|c|}{ Wtd Mean Plateau age (Ma) } & \multicolumn{2}{|c|}{ MSWD $=0.84$} & $0.058 \pm 0.006$ \\
\hline & \multirow{4}{*}{\multicolumn{2}{|c|}{ Intercept $=296.0 \pm 4.8$}} & & \multirow{2}{*}{\multicolumn{3}{|c|}{$\begin{array}{c}\text { Isochron age }(\mathrm{Ma}) \\
\text { Integrated age }(\mathrm{Ma})\end{array}$}} & \multirow{2}{*}{\multicolumn{2}{|c|}{$\mathrm{MSWD}=1.04$}} & $0.055 \pm 0.015$ \\
\hline & & & & & & & & & $0.047 \pm 0.009$ \\
\hline & & & & \multicolumn{3}{|c|}{ Recoil Age (Ma) $(50.00 \%)$} & \multicolumn{2}{|c|}{ MSWD $=0.964$} & $0.060 \pm 0.007$ \\
\hline & & & & \multicolumn{3}{|c|}{ Recoil Age (Ma) $(70.00 \%)$} & \multicolumn{2}{|c|}{ MSWD $=0.643$} & $0.057 \pm 0.007$ \\
\hline
\end{tabular}


Table 1. Chemical and modal analyses of igneous rocks of the ancestral Cascade volcanic arc, Beacon Rock 7.5' quadrangle, Skamania County, Washington.

[X-ray fluorescence analyses. Map No., see figure 16 (sheet 2). Rock-type names assigned in accordance with IUGS system (Le Maitre, 2002) applied to recalculated analyses. FeO*, total Fe calculated as $\mathrm{FeO} ; \mathrm{Mg}$, atomic ratio $100 \mathrm{Mg} /\left(\mathrm{Mg}^{2} \mathrm{Fe}^{2}+\right)$ with $\mathrm{Fe}^{2}+$ set to $0.85 \times \mathrm{Fe}^{\text {total }}$. Modal analyses, secondary minerals counted as primary mineral replaced. --, not present. Analyses by D.M. Johnson Cornelius and R.M. Conrey at Peter Hooper GeoAnalytical Laboratory of Washington State University, Pullman, Washington, using methods described in Johnson and others (1999)]

\begin{tabular}{|c|c|c|c|c|c|c|c|c|c|}
\hline Map No. & 1 & 2 & 3 & 4 & 5 & 6 & 7 & 8 & 9 \\
\hline Field sample No. & 02BV-G76 & 06BV-G634A & 06BV-G743 & 06BV-G712 & 06BV-G657B & 06BV-G630 & 06BV-G766B & 06BV-G692 & O9BV-G1280 \\
\hline Latitude (N) & $45^{\circ} 43.929^{\prime}$ & $45^{\circ} 43.707^{\prime}$ & $45^{\circ} 42.502^{\prime}$ & $45^{\circ} 43.599^{\prime}$ & $45^{\circ} 44.507^{\prime}$ & $45^{\circ} 42.922^{\prime}$ & $45^{\circ} 41.954^{\prime}$ & $45^{\circ} 44.227^{\prime}$ & $45^{\circ} 44.742^{\prime}$ \\
\hline Longitude (W) & $122^{\circ} 05.986^{\prime}$ & $122^{\circ} 05.218^{\prime}$ & $122^{\circ} 05.768^{\prime}$ & $122^{\circ} 04.247^{\prime}$ & $122^{\circ} 04.230^{\prime}$ & $122^{\circ} 06.179^{\prime}$ & $122^{\circ} 05.641^{\prime}$ & $122^{\circ} 03.790^{\prime}$ & $122^{\circ} 03.467^{\prime}$ \\
\hline Map unit & Tob & Tba & Tba & Tba & Tba & Tba & Tba & Tba & Tba \\
\hline Rock type & Basalt & $\begin{array}{c}\text { Basaltic } \\
\text { andesite }\end{array}$ & $\begin{array}{c}\text { Basaltic } \\
\text { andesite }\end{array}$ & $\begin{array}{c}\text { Basaltic } \\
\text { andesite }\end{array}$ & $\begin{array}{c}\text { Basaltic } \\
\text { andesite }\end{array}$ & $\begin{array}{c}\text { Basaltic } \\
\text { andesite }\end{array}$ & $\begin{array}{c}\text { Basaltic } \\
\text { andesite }\end{array}$ & $\begin{array}{c}\text { Basaltic } \\
\text { andesite }\end{array}$ & $\begin{array}{c}\text { Basaltic } \\
\text { andesite }\end{array}$ \\
\hline \multicolumn{10}{|c|}{ Analyses as reported (weight percent) } \\
\hline $\mathrm{SiO}_{2}$ & 50.54 & 52.84 & 53.51 & 53.99 & 53.74 & 53.95 & 54.58 & 54.42 & 54.32 \\
\hline $\mathrm{TiO}_{2}^{2}$ & 0.90 & 1.22 & 1.70 & 1.53 & 1.90 & 1.62 & 1.73 & 1.74 & 1.49 \\
\hline $\mathrm{Al}_{2} \mathrm{O}_{3}$ & 17.22 & 17.03 & 15.52 & 16.01 & 15.82 & 18.59 & 15.17 & 15.17 & 16.56 \\
\hline $\mathrm{FeO}^{2}$ & 8.90 & 9.23 & 10.93 & 10.23 & 10.54 & 8.36 & 11.11 & 11.13 & 9.28 \\
\hline $\mathrm{MnO}$ & 0.16 & 0.16 & 0.20 & 0.18 & 0.20 & 0.15 & 0.21 & 0.20 & 0.18 \\
\hline $\mathrm{MgO}$ & 8.17 & 4.79 & 4.08 & 4.42 & 3.84 & 2.75 & 4.09 & 3.82 & 3.55 \\
\hline $\mathrm{CaO}$ & 11.82 & 8.36 & 8.21 & 8.75 & 8.08 & 8.65 & 8.30 & 8.02 & 8.14 \\
\hline $\mathrm{Na}_{2} \mathrm{O}$ & 2.10 & 2.93 & 3.45 & 3.26 & 3.46 & 3.25 & 3.35 & 3.40 & 3.43 \\
\hline $\mathrm{K}_{2}^{2} \mathrm{O}$ & 0.24 & 0.98 & 0.86 & 1.00 & 0.67 & 1.08 & 0.93 & 1.12 & 1.11 \\
\hline $\mathrm{P}_{2}^{2} \mathrm{O}_{5}$ & 0.10 & 0.16 & 0.27 & 0.21 & 0.27 & 0.25 & 0.26 & 0.26 & 0.25 \\
\hline Total & 100.14 & 97.69 & 98.73 & 99.58 & 98.52 & 98.65 & 99.74 & 99.28 & 98.30 \\
\hline \multicolumn{10}{|c|}{ Analyses recalculated volatile-free and normalized to $100 \%$ with all $\mathrm{Fe}$ as $\mathrm{Fe} 0$ (weight percent) } \\
\hline $\mathrm{SiO}_{2}$ & 50.47 & 54.09 & 54.20 & 54.22 & 54.55 & 54.69 & 54.72 & 54.81 & 55.25 \\
\hline $\mathrm{TiO}_{2}^{2}$ & 0.90 & 1.24 & 1.72 & 1.54 & 1.93 & 1.64 & 1.73 & 1.75 & 1.51 \\
\hline $\mathrm{Al}_{2} \mathrm{O}_{3}^{2}$ & 17.20 & 17.43 & 15.72 & 16.08 & 16.06 & 18.84 & 15.21 & 15.28 & 16.85 \\
\hline $\mathrm{FeO}^{*}$ & 8.89 & 9.45 & 11.07 & 10.27 & 10.70 & 8.47 & 11.14 & 11.21 & 9.44 \\
\hline $\mathrm{MnO}$ & 0.16 & 0.16 & 0.20 & 0.18 & 0.20 & 0.15 & 0.21 & 0.21 & 0.18 \\
\hline $\mathrm{MgO}$ & 8.16 & 4.91 & 4.13 & 4.44 & 3.90 & 2.79 & 4.11 & 3.85 & 3.61 \\
\hline $\mathrm{CaO}$ & 11.80 & 8.56 & 8.32 & 8.79 & 8.20 & 8.77 & 8.32 & 8.08 & 8.28 \\
\hline $\mathrm{Na}_{2} \mathrm{O}$ & 2.10 & 2.99 & 3.49 & 3.27 & 3.52 & 3.30 & 3.36 & 3.42 & 3.49 \\
\hline $\mathrm{K}_{2} \mathrm{O}^{2}$ & 0.24 & 1.00 & 0.88 & 1.00 & 0.68 & 1.09 & 0.94 & 1.13 & 1.13 \\
\hline $\mathrm{P}_{2} \mathrm{O}_{5}$ & 0.09 & 0.16 & 0.27 & 0.21 & 0.27 & 0.25 & 0.26 & 0.26 & 0.26 \\
\hline $\mathrm{Mg} \#$ & 65.8 & 52.7 & 44.2 & 47.6 & 43.7 & 41.2 & 43.7 & 42.0 & 44.9 \\
\hline \multicolumn{10}{|c|}{ Modes (volume percent) } \\
\hline Plagioclase & 6.6 & 20.5 & 1.0 & 0.3 & 0.1 & 27.2 & 1.7 & 0.4 & 10.5 \\
\hline Clinopyroxene & 0.1 & 1.3 & trace & 0.1 & trace & 0.8 & trace & -- & 0.9 \\
\hline Orthopyroxene & -- & -- & -- & -- & -- & -- & -- & -- & 1.3 \\
\hline Olivine & -- & 5.1 & trace & trace & -- & 1.2 & -- & -- & -- \\
\hline Fe-Ti Oxide & -- & 0.1 & -- & -- & -- & -- & -- & -- & trace \\
\hline Hornblende & -- & -- & -- & -- & -- & -- & -- & -- & -- \\
\hline Biotite & -- & -- & -- & -- & -- & -- & -- & -- & -- \\
\hline Quartz & -- & -- & -- & -- & -- & -- & -- & -- & -- \\
\hline Groundmass & 93.3 & 73.0 & 99.0 & 99.6 & 99.9 & 70.8 & 98.3 & 99.6 & 87.3 \\
\hline No. points counted & 825 & 850 & 850 & 850 & 850 & 850 & 800 & 850 & 850 \\
\hline $\begin{array}{l}\text { Texture (rock/ } \\
\text { groundmass) }\end{array}$ & $\begin{array}{l}\text { porphyritic/ } \\
\text { trachytic }\end{array}$ & $\begin{array}{l}\text { seriate/ } \\
\text { intergranular }\end{array}$ & $\begin{array}{l}\text { aphyric/ } \\
\text { trachytic }\end{array}$ & $\begin{array}{l}\text { aphyric/ } \\
\text { trachytic }\end{array}$ & $\begin{array}{l}\text { aphyric/ } \\
\text { trachytic }\end{array}$ & $\begin{array}{l}\text { seriate/ } \\
\text { intergranular }\end{array}$ & $\begin{array}{c}\text { sparsely } \\
\text { phyric/ } \\
\text { trachytic }\end{array}$ & $\begin{array}{l}\text { aphyric/ } \\
\text { trachytic }\end{array}$ & $\begin{array}{l}\text { porphyritic/ } \\
\text { trachytic }\end{array}$ \\
\hline \multicolumn{10}{|c|}{ Trace element analyses (parts per million) } \\
\hline $\mathrm{Ba}$ & 101 & 223 & 218 & 222 & 223 & 267 & 263 & 266 & 232 \\
\hline $\mathrm{Rb}$ & 4 & 25 & 18 & 31 & 14 & 29 & 15 & 30 & 33 \\
\hline $\mathrm{Sr}$ & 303 & 248 & 268 & 264 & 298 & 307 & 256 & 253 & 288 \\
\hline $\mathrm{Y}$ & 15 & 32 & 34 & 34 & 35 & 36 & 36 & 38 & 35 \\
\hline $\mathrm{Zr}$ & 47 & 144 & 146 & 157 & 156 & 188 & 168 & 168 & 167 \\
\hline $\mathrm{Nb}$ & 3.6 & 7.3 & 8.2 & 8.3 & 10.2 & 11.0 & 8.7 & 9.4 & 10.9 \\
\hline $\mathrm{Ni}$ & 107 & 29 & 10 & 16 & 4 & 5 & 18 & 17 & 20 \\
\hline $\mathrm{Cu}$ & 108 & 122 & 169 & 166 & 70 & 99 & 169 & 244 & 166 \\
\hline $\mathrm{Zn}$ & 71 & 88 & 106 & 96 & 107 & 87 & 110 & 110 & 100 \\
\hline $\mathrm{Cr}$ & 635 & 61 & 13 & 20 & 3 & 10 & 33 & 32 & 40 \\
\hline $\mathrm{Sc}$ & 38 & 31 & 38 & 37 & 36 & 27 & 36 & 38 & 30 \\
\hline V & 235 & 228 & 279 & 287 & 277 & 216 & 301 & 301 & 238 \\
\hline
\end{tabular}


Table 1. Chemical and modal analyses of igneous rocks of the ancestral Cascade volcanic arc, Beacon Rock 7.5' quadrangle, Skamania County, Washington.-Continued

\begin{tabular}{|c|c|c|c|c|c|c|c|c|c|}
\hline Map No. & 10 & 11 & 12 & 13 & 14 & 15 & 16 & 17 & 18 \\
\hline Field sample No. & 06BV-G719C & 06BV-G686 & 06BV-G679B & 06BV-G583 & 06BV-G689B & 06BV-G745 & 06BV-G764 & 06BV-G706 & 06BV-G704 \\
\hline Latitude (N) & $45^{\circ} 43.489^{\prime}$ & $45^{\circ} 40.851^{\prime}$ & $45^{\circ} 40.798^{\prime}$ & $45^{\circ} 44.856^{\prime}$ & $45^{\circ} 43.964^{\prime}$ & $45^{\circ} 42.850^{\prime}$ & $45^{\circ} 42.248^{\prime}$ & $45^{\circ} 42.782^{\prime}$ & $45^{\circ} 43.735^{\prime}$ \\
\hline Longitude (W) & $122^{\circ} 04.018^{\prime}$ & $122^{\circ} 06.016^{\prime}$ & $122^{\circ} 07.147^{\prime}$ & $122^{\circ} 00.224^{\prime}$ & $122^{\circ} 03.651^{\prime}$ & $122^{\circ} 05.253^{\prime}$ & $122^{\circ} 05.730^{\prime}$ & $122^{\circ} 04.624^{\prime}$ & $122^{\circ} 03.723^{\prime}$ \\
\hline Map unit & Tba & Tba & Tba & Tba & Tba & Tba & Tba & $\mathrm{Td}$ & $\mathrm{Td}$ \\
\hline Rock type & $\begin{array}{l}\text { Basaltic } \\
\text { andesite }\end{array}$ & $\begin{array}{l}\text { Basaltic } \\
\text { andesite }\end{array}$ & $\begin{array}{l}\text { Basaltic } \\
\text { andesite }\end{array}$ & $\begin{array}{l}\text { Basaltic } \\
\text { andesite }\end{array}$ & $\begin{array}{c}\text { Basaltic } \\
\text { andesite }\end{array}$ & $\begin{array}{l}\text { Basaltic } \\
\text { andesite }\end{array}$ & Andesite & Dacite & Dacite \\
\hline \multicolumn{10}{|c|}{ Analyses as reported (weight percent) } \\
\hline $\mathrm{SiO}_{2}$ & 55.24 & 55.60 & 55.29 & 55.43 & 56.13 & 56.53 & 58.35 & 63.45 & 65.98 \\
\hline $\mathrm{TiO}_{2}^{2}$ & 1.77 & 1.83 & 1.66 & 1.48 & 1.89 & 1.43 & 1.70 & 1.02 & 0.97 \\
\hline $\mathrm{Al}_{2} \mathrm{O}_{3}$ & 15.41 & 15.72 & 16.03 & 16.51 & 14.97 & 15.99 & 15.74 & 15.33 & 14.25 \\
\hline $\mathrm{FeO}^{*}$ & 10.32 & 9.72 & 9.37 & 8.69 & 10.39 & 9.39 & 9.13 & 6.54 & 6.29 \\
\hline $\mathrm{MnO}$ & 0.18 & 0.18 & 0.16 & 0.18 & 0.19 & 0.18 & 0.18 & 0.15 & 0.13 \\
\hline $\mathrm{MgO}$ & 3.68 & 3.17 & 3.29 & 3.42 & 3.01 & 3.33 & 2.69 & 1.29 & 1.05 \\
\hline $\mathrm{CaO}$ & 7.64 & 7.63 & 7.76 & 7.42 & 6.99 & 7.85 & 6.37 & 4.48 & 3.23 \\
\hline $\mathrm{Na}_{2} \mathrm{O}$ & 3.49 & 3.33 & 3.24 & 3.69 & 3.85 & 3.22 & 4.19 & 4.40 & 4.68 \\
\hline $\mathrm{K}_{2} \mathrm{O}$ & 1.03 & 1.38 & 1.23 & 1.32 & 0.95 & 1.24 & 1.19 & 2.20 & 2.14 \\
\hline $\mathrm{P}_{2} \mathrm{O}_{5}$ & 0.34 & 0.32 & 0.28 & 0.27 & 0.41 & 0.21 & 0.34 & 0.28 & 0.28 \\
\hline Total & 99.10 & 98.88 & 98.32 & 98.40 & 98.77 & 99.37 & 99.88 & 99.13 & 99.00 \\
\hline \multicolumn{10}{|c|}{ Analyses recalculated volatile-free and normalized to $100 \%$ with all $\mathrm{Fe}$ as $\mathrm{Fe} 0$ (weight percent) } \\
\hline $\mathrm{SiO}_{2}$ & 55.75 & 56.23 & 56.24 & 56.32 & 56.82 & 56.89 & 58.42 & 64.00 & 66.64 \\
\hline $\mathrm{TiO}_{2}^{2}$ & 1.78 & 1.85 & 1.69 & 1.50 & 1.91 & 1.43 & 1.71 & 1.03 & 0.98 \\
\hline $\mathrm{Al}_{2} \mathrm{O}_{3}^{2}$ & 15.55 & 15.89 & 16.30 & 16.78 & 15.15 & 16.09 & 15.76 & 15.46 & 14.39 \\
\hline $\mathrm{FeO}^{*}$ & 10.41 & 9.83 & 9.53 & 8.83 & 10.52 & 9.45 & 9.14 & 6.60 & 6.35 \\
\hline $\mathrm{MnO}$ & 0.18 & 0.19 & 0.16 & 0.19 & 0.20 & 0.18 & 0.18 & 0.15 & 0.13 \\
\hline $\mathrm{MgO}$ & 3.71 & 3.20 & 3.35 & 3.48 & 3.04 & 3.35 & 2.70 & 1.30 & 1.06 \\
\hline $\mathrm{CaO}$ & 7.71 & 7.72 & 7.89 & 7.54 & 7.08 & 7.90 & 6.38 & 4.52 & 3.27 \\
\hline $\mathrm{Na}_{2} \mathrm{O}$ & 3.52 & 3.36 & 3.29 & 3.75 & 3.90 & 3.24 & 4.19 & 4.44 & 4.73 \\
\hline $\mathrm{K}_{2} \mathrm{O}$ & 1.04 & 1.39 & 1.25 & 1.34 & 0.96 & 1.25 & 1.19 & 2.22 & 2.16 \\
\hline $\mathrm{P}_{2}^{2} \mathrm{O}_{5}$ & 0.34 & 0.33 & 0.29 & 0.27 & 0.41 & 0.21 & 0.34 & 0.28 & 0.29 \\
\hline $\mathrm{Mg} \#$ & 43.0 & 40.9 & 42.9 & 45.6 & 38.0 & 42.8 & 38.2 & 29.4 & 26.1 \\
\hline \multicolumn{10}{|c|}{ Modes (volume percent) } \\
\hline Plagioclase & 8.9 & 0.2 & -- & 19.4 & 0.2 & 0.3 & 1.4 & 9.0 & 3.3 \\
\hline Clinopyroxene & 1.1 & -- & -- & 2.5 & -- & -- & 0.3 & 1.4 & 0.5 \\
\hline Orthopyroxene & 0.7 & trace & -- & 0.5 & -- & -- & 0.2 & 1.4 & 0.4 \\
\hline Olivine & 1.6 & -- & -- & 1.4 & -- & -- & trace & -- & -- \\
\hline Fe-Ti Oxide & trace & trace & -- & 0.1 & trace & -- & 0.2 & 0.3 & 0.2 \\
\hline Hornblende & -- & -- & -- & -- & -- & -- & -- & -- & -- \\
\hline Biotite & -- & -- & -- & -- & -- & -- & -- & -- & -- \\
\hline Other & -- & -- & -- & -- & -- & -- & -- & -- & -- \\
\hline Groundmass & 87.7 & 99.8 & 100.0 & 76.1 & 99.8 & 99.7 & 97.9 & 87.9 & 95.6 \\
\hline No. points counted & 850 & 850 & -- & 850 & 850 & 850 & 850 & 790 & 850 \\
\hline $\begin{array}{l}\text { Texture (rock/ } \\
\text { groundmass) }\end{array}$ & $\begin{array}{l}\text { seriate/ } \\
\text { intersertal }\end{array}$ & $\begin{array}{l}\text { aphyric/ } \\
\text { microseriate }\end{array}$ & $\begin{array}{l}\text { microphyric/ } \\
\text { intersertal }\end{array}$ & $\begin{array}{l}\text { porphyritic/ } \\
\text { intergranular }\end{array}$ & $\begin{array}{l}\text { aphyric/ } \\
\text { pilotaxitic }\end{array}$ & $\begin{array}{l}\text { aphyric/ } \\
\text { microseriate }\end{array}$ & $\begin{array}{l}\text { sparsely } \\
\text { phyric } \\
\text { phyric/ } \\
\text { pilotaxitic }\end{array}$ & $\begin{array}{l}\text { seriate/ } \\
\text { pilotaxitic }\end{array}$ & $\begin{array}{l}\text { sparsely } \\
\text { phyric/ } \\
\text { micropoikil- } \\
\text { itic }\end{array}$ \\
\hline \multicolumn{10}{|c|}{ Trace element analyses (parts per million) } \\
\hline $\mathrm{Ba}$ & 269 & 307 & 289 & 298 & 286 & 258 & 299 & 408 & 464 \\
\hline $\mathrm{Rb}$ & 28 & 47 & 47 & 38 & 39 & 19 & 32 & 67 & 65 \\
\hline $\mathrm{Sr}$ & 262 & 264 & 271 & 354 & 262 & 247 & 277 & 223 & 182 \\
\hline $\mathrm{Y}$ & 40 & 40 & 37 & 31 & 42 & 34 & 41 & 55 & 57 \\
\hline $\mathrm{Zr}$ & 195 & 232 & 198 & 180 & 202 & 172 & 207 & 292 & 323 \\
\hline $\mathrm{Nb}$ & 11.9 & 12.5 & 9.9 & 9.6 & 12.3 & 8.5 & 11.8 & 15.4 & 17.0 \\
\hline $\mathrm{Ni}$ & 19 & 9 & 13 & 17 & 5 & 10 & 2 & 4 & 0 \\
\hline $\mathrm{Cu}$ & 176 & 202 & 229 & 98 & 132 & 152 & 93 & 60 & 44 \\
\hline $\mathrm{Zn}$ & 107 & 107 & 99 & 102 & 109 & 94 & 107 & 90 & 111 \\
\hline $\mathrm{Cr}$ & 56 & 15 & 18 & 21 & 4 & 17 & 3 & 10 & 1 \\
\hline $\mathrm{Sc}$ & 33 & 32 & 32 & 28 & 34 & 30 & 28 & 21 & 20 \\
\hline V & 201 & 281 & 245 & 209 & 179 & 245 & 170 & 71 & 19 \\
\hline
\end{tabular}


Table 1. Chemical and modal analyses of igneous rocks of the ancestral Cascade volcanic arc, Beacon Rock 7.5' quadrangle, Skamania County, Washington.-Continued

\begin{tabular}{|c|c|c|c|c|c|c|c|c|c|}
\hline Map No. & 19 & 20 & 21 & 22 & 23 & 24 & 25 & 26 & 27 \\
\hline Field sample No. & 06BV-G780 & 06BV-G792A & 06BV-G719A & 08BV-G1197 & 06BV-G600 & 02BV-G88 & 06BV-G626 & 06BV-G589 & 06BV-G601' \\
\hline Latitude (N) & $45^{\circ} 41.135^{\prime}$ & $45^{\circ} 40.579^{\prime}$ & $45^{\circ} 43.513^{\prime}$ & $45^{\circ} 38.354^{\prime}$ & $45^{\circ} 43.330^{\prime}$ & $45^{\circ} 41.033^{\prime}$ & $45^{\circ} 41.317^{\prime}$ & $45^{\circ} 44.569^{\prime}$ & $45^{\circ} 44.624^{\prime}$ \\
\hline Longitude (W) & $122^{\circ} 06.663^{\prime}$ & $122^{\circ} 06.259^{\prime}$ & $122^{\circ} 04.054^{\prime}$ & $122^{\circ} 05.270^{\prime}$ & $122^{\circ} 03.494^{\prime}$ & $122^{\circ} 03.736^{\prime}$ & $122^{\circ} 04.789^{\prime}$ & $122^{\circ} 02.599^{\prime}$ & $122^{\circ} 02.469^{\prime}$ \\
\hline Map unit & $\mathrm{Td}$ & Ttw & Tts & Thba & Thba & Thba & Thba & Thba & Thba \\
\hline Rock type & Dacite & $\begin{array}{c}\text { Dacite } \\
\text { Welded Tuff }\end{array}$ & $\begin{array}{c}\text { Rhyolite } \\
\text { Welded Tuff }\end{array}$ & $\begin{array}{c}\text { Basaltic } \\
\text { andesite }\end{array}$ & $\begin{array}{c}\text { Basaltic } \\
\text { andesite }\end{array}$ & $\begin{array}{c}\text { Basaltic } \\
\text { andesite }\end{array}$ & $\begin{array}{c}\text { Basaltic } \\
\text { andesite }\end{array}$ & $\begin{array}{c}\text { Basaltic } \\
\text { andesite }\end{array}$ & $\begin{array}{c}\text { Basaltic } \\
\text { andesite }\end{array}$ \\
\hline \multicolumn{10}{|c|}{ Analyses as reported (weight percent) } \\
\hline $\mathrm{SiO}_{2}$ & 63.30 & 67.23 & 73.38 & 49.66 & 51.82 & 51.67 & 52.72 & 53.07 & 53.88 \\
\hline $\mathrm{TiO}_{2}^{2}$ & 0.77 & 0.54 & 0.48 & 1.35 & 1.08 & 1.04 & 1.07 & 1.17 & 1.08 \\
\hline $\mathrm{Al}_{2} \stackrel{2}{3}_{3}$ & 14.16 & 15.29 & 12.39 & 18.78 & 19.59 & 18.73 & 18.88 & 18.95 & 19.73 \\
\hline $\mathrm{FeO}^{*}$ & 5.53 & 3.85 & 3.04 & 8.34 & 7.96 & 8.00 & 8.06 & 7.75 & 7.27 \\
\hline $\mathrm{MnO}$ & 0.13 & 0.05 & 0.11 & 0.19 & 0.16 & 0.14 & 0.14 & 0.13 & 0.13 \\
\hline $\mathrm{MgO}$ & 0.93 & 0.46 & 0.31 & 4.31 & 4.74 & 5.40 & 5.23 & 4.34 & 3.63 \\
\hline $\mathrm{CaO}$ & 4.65 & 2.60 & 1.94 & 9.32 & 9.99 & 9.57 & 9.44 & 9.11 & 9.48 \\
\hline $\mathrm{Na}_{2} \mathrm{O}$ & 3.79 & 3.89 & 4.46 & 3.08 & 3.07 & 2.98 & 3.09 & 3.36 & 3.36 \\
\hline $\mathrm{K}_{2} \mathrm{O}$ & 0.91 & 2.86 & 2.23 & 0.30 & 0.50 & 0.73 & 0.77 & 0.73 & 0.72 \\
\hline $\mathrm{P}_{2} \mathrm{O}_{5}$ & 0.21 & 0.08 & 0.10 & 0.22 & 0.14 & 0.15 & 0.15 & 0.17 & 0.16 \\
\hline Total & 94.39 & 96.84 & 98.43 & 95.57 & 99.05 & 98.39 & 99.54 & 98.78 & 99.45 \\
\hline \multicolumn{10}{|c|}{ Analyses recalculated volatile-free and normalized to $100 \%$ with all $\mathrm{Fe}$ as $\mathrm{FeO}$ (weight percent) } \\
\hline $\mathrm{SiO}_{2}$ & 67.07 & 69.42 & 74.55 & 51.96 & 52.32 & 52.51 & 52.96 & 53.73 & 54.17 \\
\hline $\mathrm{TiO}_{2}^{2}$ & 0.81 & 0.56 & 0.49 & 1.42 & 1.09 & 1.05 & 1.08 & 1.19 & 1.09 \\
\hline $\mathrm{Al}_{2} \mathrm{O}_{3}$ & 15.00 & 15.79 & 12.58 & 19.65 & 19.78 & 19.03 & 18.96 & 19.19 & 19.84 \\
\hline $\mathrm{FeO}^{*}$ & 5.86 & 3.97 & 3.09 & 8.73 & 8.03 & 8.13 & 8.09 & 7.84 & 7.31 \\
\hline $\mathrm{MnO}$ & 0.14 & 0.05 & 0.11 & 0.20 & 0.16 & 0.14 & 0.14 & 0.13 & 0.13 \\
\hline $\mathrm{MgO}$ & 0.99 & 0.47 & 0.31 & 4.51 & 4.79 & 5.49 & 5.25 & 4.40 & 3.65 \\
\hline $\mathrm{CaO}$ & 4.92 & 2.68 & 1.97 & 9.75 & 10.09 & 9.73 & 9.49 & 9.22 & 9.53 \\
\hline $\mathrm{Na}_{2} \mathrm{O}$ & 4.02 & 4.02 & 4.53 & 3.23 & 3.09 & 3.03 & 3.10 & 3.40 & 3.38 \\
\hline $\mathrm{K}_{2}^{2} \mathrm{O}$ & 0.97 & 2.95 & 2.26 & 0.32 & 0.50 & 0.74 & 0.78 & 0.74 & 0.73 \\
\hline $\mathrm{P}_{2}^{2} \mathrm{O}_{5}$ & 0.23 & 0.08 & 0.10 & 0.23 & 0.15 & 0.15 & 0.15 & 0.17 & 0.16 \\
\hline $\mathrm{Mg} \#$ & 27.3 & 20.5 & 17.6 & 53.1 & 55.8 & 59.0 & 57.8 & 54.3 & 51.3 \\
\hline \multicolumn{10}{|c|}{ Modes (volume percent) } \\
\hline Plagioclase & 1.9 & 18.0 & 2.0 & 31.3 & 23.3 & 31.5 & 27.4 & 24.3 & 25.7 \\
\hline Clinopyroxene & 0.6 & 0.3 & 0.3 & -- & 0.8 & 0.9 & 1.4 & 0.3 & 0.6 \\
\hline Orthopyroxene & 0.6 & 1.8 & 0.2 & 0.4 & -- & -- & -- & -- & -- \\
\hline Olivine & -- & -- & -- & 2.4 & 4.3 & 3.8 & 5.5 & 1.9 & 2.9 \\
\hline Fe-Ti Oxide & 0.1 & 0.1 & 0.1 & -- & -- & -- & -- & -- & -- \\
\hline Hornblende & -- & -- & -- & -- & -- & -- & -- & -- & -- \\
\hline Biotite & -- & -- & -- & -- & -- & -- & -- & -- & -- \\
\hline Other & -- & -- & -- & -- & -- & -- & -- & -- & -- \\
\hline Groundmass & 96.8 & 79.8 & 97.4 & 65.9 & 71.6 & 63.8 & 65.7 & 73.5 & 70.8 \\
\hline No. points counted & 850 & 850 & 850 & 830 & 850 & 850 & 850 & 850 & 850 \\
\hline $\begin{array}{l}\text { Texture (rock/ } \\
\text { groundmass) }\end{array}$ & $\begin{array}{l}\text { sparsely } \\
\text { phyric/ } \\
\text { pilotaxitic }\end{array}$ & $\begin{array}{l}\text { porphyritic/ } \\
\text { eutaxitic }\end{array}$ & $\begin{array}{c}\text { sparsely } \\
\text { phyric/ } \\
\text { eutaxitic }\end{array}$ & $\begin{array}{l}\text { seriate/ } \\
\text { intersertal }\end{array}$ & $\begin{array}{l}\text { seriate/ } \\
\text { intergranular }\end{array}$ & $\begin{array}{l}\text { seriate/ } \\
\text { intergranular }\end{array}$ & $\begin{array}{l}\text { seriate/ } \\
\text { intergranular }\end{array}$ & $\begin{array}{l}\text { porphyritic/ } \\
\text { intergranular }\end{array}$ & $\begin{array}{l}\text { porphyritic/ } \\
\text { intergranular }\end{array}$ \\
\hline \multicolumn{10}{|c|}{ Trace element analyses (parts per million) } \\
\hline $\mathrm{Ba}$ & 507 & 482 & 493 & 205 & 169 & 182 & 187 & 200 & 192 \\
\hline $\mathrm{Rb}$ & 86 & 99 & 65 & 8 & 12 & 19 & 20 & 20 & 23 \\
\hline $\mathrm{Sr}$ & 295 & 161 & 112 & 406 & 416 & 466 & 467 & 386 & 420 \\
\hline $\mathrm{Y}$ & 47 & 21 & 48 & 24 & 18 & 17 & 19 & 19 & 19 \\
\hline $\mathrm{Zr}$ & 290 & 278 & 329 & 146 & 89 & 88 & 95 & 105 & 94 \\
\hline $\mathrm{Nb}$ & 14.8 & 10.1 & 17.2 & 7.6 & 4.6 & 4.4 & 4.5 & 6.3 & 5.4 \\
\hline $\mathrm{Ni}$ & 0 & 5 & 0 & 13 & 33 & 30 & 29 & 18 & 20 \\
\hline $\mathrm{Cu}$ & 50 & 50 & 21 & 144 & 109 & 69 & 125 & 152 & 105 \\
\hline $\mathrm{Zn}$ & 88 & 46 & 85 & 93 & 79 & 79 & 79 & 80 & 74 \\
\hline $\mathrm{Cr}$ & 3 & 8 & 2 & 39 & 45 & 49 & 43 & 43 & 42 \\
\hline $\mathrm{Sc}$ & 17 & 10 & 12 & 29 & 26 & 25 & 26 & 26 & 23 \\
\hline $\mathrm{V}$ & 18 & 57 & 4 & 218 & 210 & 210 & 212 & 202 & 192 \\
\hline
\end{tabular}

${ }^{1}$ Block in talus deposit. 
Table 1. Chemical and modal analyses of igneous rocks of the ancestral Cascade volcanic arc, Beacon Rock 7.5' quadrangle, Skamania County, Washington.-Continued

\begin{tabular}{|c|c|c|c|c|c|c|c|c|c|}
\hline Map No. & 28 & 29 & 30 & 31 & 32 & 33 & 34 & 35 & 36 \\
\hline Field sample No. & 06BV-G614 & 06BV-G618 & 02BV-G11B & 02BV-G85² & 06BV-G594 & 06BV-G703 & 06BV-G615 & 02BV-G52A & 02BV-G64B \\
\hline Latitude (N) & $45^{\circ} 42.617^{\prime}$ & $45^{\circ} 42.595^{\prime}$ & $45^{\circ} 43.298^{\prime}$ & $45^{\circ} 42.920^{\prime}$ & $45^{\circ} 43.816^{\prime}$ & $45^{\circ} 43.048^{\prime}$ & $45^{\circ} 42.386^{\prime}$ & $45^{\circ} 43.316^{\prime}$ & $45^{\circ} 40.588^{\prime}$ \\
\hline Longitude (W) & $122^{\circ} 03.891^{\prime}$ & $122^{\circ} 04.958^{\prime}$ & $122^{\circ} 03.421^{\prime}$ & $122^{\circ} 04.283^{\prime}$ & $122^{\circ} 03.345^{\prime}$ & $122^{\circ} 03.824^{\prime}$ & $122^{\circ} 04.279^{\prime}$ & $122^{\circ} 03.665^{\prime}$ & $122^{\circ} 03.944^{\prime}$ \\
\hline Map unit & Thba & Thba & Thba & Thba & Thba & Thba & Thba & Thba & Thba \\
\hline Rock type & $\begin{array}{l}\text { Basaltic } \\
\text { andesite }\end{array}$ & $\begin{array}{l}\text { Basaltic } \\
\text { andesite }\end{array}$ & $\begin{array}{l}\text { Basaltic } \\
\text { andesite }\end{array}$ & $\begin{array}{l}\text { Basaltic } \\
\text { andesite }\end{array}$ & $\begin{array}{l}\text { Basaltic } \\
\text { andesite }\end{array}$ & $\begin{array}{l}\text { Basaltic } \\
\text { andesite }\end{array}$ & $\begin{array}{l}\text { Basaltic } \\
\text { andesite }\end{array}$ & $\begin{array}{l}\text { Basaltic } \\
\text { andesite }\end{array}$ & $\begin{array}{l}\text { Basaltic } \\
\text { andesite }\end{array}$ \\
\hline \multicolumn{10}{|c|}{ Analyses as reported (weight percent) } \\
\hline $\mathrm{SiO}_{2}$ & 53.46 & 54.55 & 55.07 & 54.63 & 55.31 & 55.83 & 56.10 & 56.18 & 55.83 \\
\hline $\mathrm{TiO}_{2}^{2}$ & 1.10 & 1.12 & 1.47 & 1.03 & 1.03 & 1.05 & 1.71 & 1.13 & 1.25 \\
\hline $\mathrm{Al}_{2} \mathrm{O}_{3}$ & 18.84 & 17.71 & 17.89 & 18.27 & 18.76 & 18.25 & 16.72 & 18.43 & 17.91 \\
\hline $\mathrm{FeO}^{*}$ & 7.78 & 8.00 & 8.71 & 7.73 & 7.18 & 7.54 & 8.84 & 7.49 & 7.67 \\
\hline $\mathrm{MnO}$ & 0.14 & 0.17 & 0.14 & 0.15 & 0.13 & 0.14 & 0.16 & 0.15 & 0.13 \\
\hline $\mathrm{MgO}$ & 4.15 & 4.19 & 3.19 & 4.51 & 3.40 & 3.77 & 3.26 & 3.30 & 3.05 \\
\hline $\mathrm{CaO}$ & 8.86 & 8.39 & 8.08 & 8.73 & 8.69 & 8.10 & 7.50 & 8.25 & 7.70 \\
\hline $\mathrm{Na}_{2} \mathrm{O}$ & 3.28 & 3.51 & 3.45 & 3.34 & 3.53 & 3.63 & 4.00 & 3.61 & 3.69 \\
\hline $\mathrm{K}_{2}^{2} \mathrm{O}$ & 0.81 & 0.75 & 1.18 & 0.72 & 0.89 & 0.78 & 1.05 & 0.81 & 1.10 \\
\hline $\mathrm{P}_{2}^{2} \mathrm{O}_{5}$ & 0.16 & 0.15 & 0.27 & 0.16 & 0.17 & 0.18 & 0.29 & 0.18 & 0.21 \\
\hline Total & 98.58 & 98.54 & 99.45 & 99.26 & 99.09 & 99.27 & 99.61 & 99.53 & 98.55 \\
\hline \multicolumn{10}{|c|}{ Analyses recalculated volatile-free and normalized to $100 \%$ with all $\mathrm{Fe}$ as $\mathrm{FeO}$ (weight percent) } \\
\hline $\mathrm{SiO}_{2}$ & 54.23 & 55.35 & 55.38 & 55.04 & 55.82 & 56.24 & 56.31 & 56.44 & 56.65 \\
\hline $\mathrm{TiO}_{2}^{2}$ & 1.12 & 1.13 & 1.48 & 1.03 & 1.04 & 1.05 & 1.71 & 1.14 & 1.27 \\
\hline $\mathrm{Al}_{2} \mathrm{O}_{3}$ & 19.11 & 17.98 & 17.99 & 18.40 & 18.93 & 18.38 & 16.78 & 18.51 & 18.18 \\
\hline $\mathrm{FeO}^{2}$ & 7.90 & 8.12 & 8.76 & 7.79 & 7.25 & 7.60 & 8.88 & 7.53 & 7.78 \\
\hline $\mathrm{MnO}$ & 0.14 & 0.17 & 0.14 & 0.15 & 0.14 & 0.14 & 0.16 & 0.15 & 0.13 \\
\hline $\mathrm{MgO}$ & 4.20 & 4.25 & 3.21 & 4.54 & 3.43 & 3.80 & 3.27 & 3.31 & 3.10 \\
\hline $\mathrm{CaO}$ & 8.99 & 8.51 & 8.12 & 8.80 & 8.77 & 8.16 & 7.52 & 8.29 & 7.82 \\
\hline $\mathrm{Na}_{2} \mathrm{O}$ & 3.33 & 3.56 & 3.47 & 3.37 & 3.56 & 3.66 & 4.01 & 3.63 & 3.75 \\
\hline $\mathrm{K}_{2} \mathrm{O}$ & 0.83 & 0.77 & 1.19 & 0.73 & 0.90 & 0.78 & 1.05 & 0.82 & 1.12 \\
\hline $\mathrm{P}_{2} \mathrm{O}_{5}$ & 0.17 & 0.15 & 0.27 & 0.16 & 0.17 & 0.18 & 0.29 & 0.18 & 0.22 \\
\hline $\mathrm{Mg} \#$ & 53.1 & 52.7 & 43.6 & 55.2 & 50.0 & 51.4 & 43.7 & 48.1 & 45.9 \\
\hline \multicolumn{10}{|c|}{ Modes (volume percent) } \\
\hline Plagioclase & 1.9 & 18.0 & 2.0 & 31.3 & 23.3 & 31.5 & 27.4 & 24.3 & 25.7 \\
\hline Clinopyroxene & 0.6 & 0.3 & 0.3 & -- & 0.8 & 0.9 & 1.4 & 0.3 & 0.6 \\
\hline Orthopyroxene & 0.6 & 1.8 & 0.2 & 0.4 & -- & -- & -- & -- & -- \\
\hline Olivine & -- & -- & -- & 2.4 & 4.3 & 3.8 & 5.5 & 1.9 & 2.9 \\
\hline Fe-Ti Oxide & 0.1 & 0.1 & 0.1 & -- & -- & -- & -- & -- & -- \\
\hline Hornblende & -- & -- & -- & -- & -- & -- & -- & -- & -- \\
\hline Biotite & -- & -- & -- & -- & -- & -- & -- & -- & -- \\
\hline Other & -- & -- & -- & -- & -- & -- & -- & -- & -- \\
\hline Groundmass & 96.8 & 79.8 & 97.4 & 65.9 & 71.6 & 63.8 & 65.7 & 73.5 & 70.8 \\
\hline No. points counted & 850 & 850 & 850 & 850 & 850 & 850 & 850 & 850 & 850 \\
\hline $\begin{array}{l}\text { Texture (rock/ } \\
\text { groundmass) }\end{array}$ & $\begin{array}{l}\text { sparsely } \\
\text { phyric/ } \\
\text { pilotaxitic }\end{array}$ & $\begin{array}{l}\text { porphyritic/ } \\
\text { eutaxitic }\end{array}$ & $\begin{array}{c}\text { sparsely } \\
\text { phyric/ } \\
\text { eutaxitic }\end{array}$ & $\begin{array}{l}\text { seriate/ } \\
\text { intersertal }\end{array}$ & $\begin{array}{l}\text { seriate/ } \\
\text { intergranular }\end{array}$ & $\begin{array}{l}\text { seriate/ } \\
\text { intergranular }\end{array}$ & $\begin{array}{l}\text { seriate/ } \\
\text { intergranular }\end{array}$ & $\begin{array}{l}\text { porphyritic/ } \\
\text { intergranular }\end{array}$ & $\begin{array}{l}\text { porphyritic/ } \\
\text { intergranular }\end{array}$ \\
\hline \multicolumn{10}{|c|}{ Trace element analyses (parts per million) } \\
\hline $\mathrm{Ba}$ & 208 & 208 & 284 & 186 & 218 & 226 & 281 & 228 & 270 \\
\hline $\mathrm{Rb}$ & 25 & 21 & 38 & 23 & 25 & 24 & 30 & 34 & 33 \\
\hline $\mathrm{Sr}$ & 373 & 364 & 341 & 370 & 400 & 387 & 364 & 364 & 357 \\
\hline $\mathrm{Y}$ & 20 & 24 & 30 & 18 & 18 & 18 & 27 & 19 & 27 \\
\hline $\mathrm{Zr}$ & 113 & 93 & 174 & 97 & 109 & 114 & 153 & 111 & 156 \\
\hline $\mathrm{Nb}$ & 6.5 & 4.4 & 11.7 & 5.1 & 5.0 & 6.0 & 9.0 & 5.5 & 8.3 \\
\hline $\mathrm{Ni}$ & 21 & 12 & 11 & 26 & 9 & 20 & 13 & 8 & 10 \\
\hline $\mathrm{Cu}$ & 59 & 50 & 152 & 99 & 97 & 84 & 167 & 98 & 59 \\
\hline $\mathrm{Zn}$ & 82 & 82 & 96 & 84 & 79 & 82 & 100 & 78 & 94 \\
\hline $\mathrm{Cr}$ & 33 & 27 & 23 & 56 & 23 & 33 & 27 & 23 & 22 \\
\hline $\mathrm{Sc}$ & 26 & 28 & 27 & 25 & 24 & 23 & 27 & 24 & 25 \\
\hline $\mathrm{V}$ & 203 & 234 & 213 & 198 & 188 & 181 & 249 & 198 & 187 \\
\hline
\end{tabular}

\footnotetext{
${ }^{2}$ Block in landslide deposit.
} 
Table 1. Chemical and modal analyses of igneous rocks of the ancestral Cascade volcanic arc, Beacon Rock 7.5' quadrangle, Skamania County, Washington.-Continued

\begin{tabular}{|c|c|c|c|c|c|c|c|c|c|}
\hline Map No. & 37 & 38 & 39 & 40 & 41 & 42 & 43 & 44 & 45 \\
\hline Field sample No. & 02BV-G83A & 02BV-G70 & 06BV-G585 & 06BV-G720 & 06BV-G622 & 02BV-G69 & 02BV-G53 & 06BV-G616 & 06BV-G791 \\
\hline Latitude (N) & $45^{\circ} 42.150^{\prime}$ & $45^{\circ} 41.993^{\prime}$ & $45^{\circ} 44.599^{\prime}$ & $45^{\circ} 42.672^{\prime}$ & $45^{\circ} 41.721^{\prime}$ & $45^{\circ} 41.721^{\prime}$ & $45^{\circ} 42.908^{\prime}$ & $45^{\circ} 42.285^{\prime}$ & $45^{\circ} 40.530^{\prime}$ \\
\hline Longitude (W) & $122^{\circ} 05.249^{\prime}$ & $122^{\circ} 01.972^{\prime}$ & $122^{\circ} 00.717^{\prime}$ & $122^{\circ} 01.024^{\prime}$ & $122^{\circ} 04.598^{\prime}$ & $122^{\circ} 04.598^{\prime}$ & $122^{\circ} 03.356^{\prime}$ & $122^{\circ} 04.567^{\prime}$ & $122^{\circ} 06.198^{\prime}$ \\
\hline Map unit & Thba & Thba & Thba & Tha & Tha & Tha & Tha & Tha & Tha \\
\hline Rock type & $\begin{array}{c}\text { Basaltic } \\
\text { andesite }\end{array}$ & $\begin{array}{l}\text { Basaltic } \\
\text { andesite }\end{array}$ & $\begin{array}{l}\text { Basaltic } \\
\text { andesite }\end{array}$ & Andesite & Andesite & Andesite & Andesite & Andesite & Andesite \\
\hline \multicolumn{10}{|c|}{ Analyses as reported (weight percent) } \\
\hline $\mathrm{SiO}_{2}$ & 55.78 & 55.98 & 56.44 & 56.42 & 56.69 & 57.36 & 56.59 & 57.19 & 57.24 \\
\hline $\mathrm{TiO}_{2}^{2}$ & 1.05 & 0.95 & 1.15 & 1.28 & 1.25 & 1.15 & 1.45 & 1.16 & 0.93 \\
\hline $\mathrm{Al}_{2} \mathrm{O}_{3}^{2}$ & 17.73 & 16.45 & 19.11 & 17.53 & 17.46 & 17.73 & 16.61 & 17.06 & 18.49 \\
\hline $\mathrm{FeO}^{2}$ & 7.55 & 7.07 & 6.41 & 6.99 & 7.39 & 7.32 & 8.27 & 7.44 & 6.67 \\
\hline $\mathrm{MnO}$ & 0.14 & 0.14 & 0.13 & 0.10 & 0.13 & 0.14 & 0.14 & 0.14 & 0.12 \\
\hline $\mathrm{MgO}$ & 3.74 & 5.33 & 2.72 & 3.65 & 3.27 & 4.02 & 2.50 & 3.48 & 2.94 \\
\hline $\mathrm{CaO}$ & 7.46 & 7.76 & 7.87 & 7.42 & 7.48 & 7.26 & 6.85 & 7.17 & 7.57 \\
\hline $\mathrm{Na}_{2} \mathrm{O}$ & 3.75 & 3.04 & 3.91 & 3.71 & 3.81 & 3.51 & 3.78 & 3.86 & 3.76 \\
\hline $\mathrm{K}_{2} \mathrm{O}$ & 0.85 & 1.58 & 1.13 & 1.46 & 1.07 & 1.18 & 1.38 & 1.14 & 0.98 \\
\hline $\mathrm{P}_{2}^{2} \mathrm{O}_{5}$ & 0.18 & 0.14 & 0.26 & 0.24 & 0.26 & 0.25 & 0.28 & 0.20 & 0.17 \\
\hline Total & 98.24 & 98.44 & 99.13 & 98.80 & 98.82 & 99.92 & 97.86 & 98.84 & 98.88 \\
\hline \multicolumn{10}{|c|}{ Analyses recalculated volatile-free and normalized to $100 \%$ with all $\mathrm{Fe}$ as $\mathrm{Fe} 0$ (weight percent) } \\
\hline $\mathrm{SiO}_{2}$ & 56.78 & 56.86 & 56.94 & 57.11 & 57.37 & 57.41 & 57.83 & 57.86 & 57.89 \\
\hline $\mathrm{TiO}_{2}^{2}$ & 1.07 & 0.97 & 1.16 & 1.30 & 1.27 & 1.15 & 1.48 & 1.17 & 0.94 \\
\hline $\mathrm{Al}_{2} \mathrm{O}_{3}$ & 18.05 & 16.71 & 19.28 & 17.74 & 17.67 & 17.74 & 16.98 & 17.26 & 18.70 \\
\hline $\mathrm{FeO}^{*}$ & 7.68 & 7.19 & 6.46 & 7.08 & 7.47 & 7.33 & 8.45 & 7.53 & 6.75 \\
\hline $\mathrm{MnO}$ & 0.15 & 0.14 & 0.13 & 0.10 & 0.13 & 0.14 & 0.14 & 0.14 & 0.13 \\
\hline $\mathrm{MgO}$ & 3.81 & 5.41 & 2.75 & 3.69 & 3.31 & 4.02 & 2.55 & 3.52 & 2.97 \\
\hline $\mathrm{CaO}$ & 7.59 & 7.88 & 7.94 & 7.51 & 7.57 & 7.27 & 7.00 & 7.26 & 7.66 \\
\hline $\mathrm{Na}_{2} \mathrm{O}$ & 3.82 & 3.09 & 3.94 & 3.76 & 3.86 & 3.51 & 3.86 & 3.91 & 3.80 \\
\hline $\mathrm{K}_{2}^{2} \mathrm{O}$ & 0.87 & 1.61 & 1.14 & 1.48 & 1.09 & 1.18 & 1.41 & 1.16 & 0.99 \\
\hline $\mathrm{P}_{2} \mathrm{O}_{5}$ & 0.19 & 0.15 & 0.26 & 0.24 & 0.26 & 0.25 & 0.29 & 0.20 & 0.17 \\
\hline $\mathrm{Mg} \#$ & 51.4 & 61.6 & 47.3 & 52.5 & 48.5 & 53.5 & 39.3 & 49.8 & 48.3 \\
\hline \multicolumn{10}{|c|}{ Modes (volume percent) } \\
\hline Plagioclase & 25.4 & 16.4 & 31.2 & 25.5 & 25.2 & 21.8 & 16.1 & 25.2 & 31.2 \\
\hline Clinopyroxene & 2.4 & 5.1 & 1.5 & 1.8 & 5.5 & 0.6 & 1.9 & 3.0 & 3.6 \\
\hline Orthopyroxene & 1.5 & 3.3 & 0.4 & 2.6 & 2.4 & 4.7 & 0.3 & 2.4 & 4.6 \\
\hline Olivine & 0.5 & 2.5 & 1.3 & 0.9 & 0.8 & 0.1 & 0.9 & 1.5 & 0.4 \\
\hline Fe-Ti Oxide & 0.2 & 0.2 & 0.1 & 0.1 & 1.3 & 0.1 & 0.1 & 0.5 & 0.8 \\
\hline Hornblende & -- & -- & -- & -- & -- & -- & -- & -- & -- \\
\hline Biotite & -- & -- & -- & -- & -- & -- & -- & -- & -- \\
\hline Other & -- & -- & -- & -- & -- & -- & -- & -- & -- \\
\hline Groundmass & 70.0 & 72.5 & 65.5 & 69.1 & 64.8 & 72.7 & 80.7 & 67.4 & 59.4 \\
\hline No. points counted & 850 & 850 & 850 & 850 & 850 & 850 & 850 & 850 & 850 \\
\hline $\begin{array}{l}\text { Texture (rock/ } \\
\text { groundmass) }\end{array}$ & $\begin{array}{l}\text { porphyritic/ } \\
\text { intergran- } \\
\text { ular }\end{array}$ & $\begin{array}{l}\text { porphyritic/ } \\
\text { intergranular }\end{array}$ & $\begin{array}{l}\text { porphyritic/ } \\
\text { intersertal }\end{array}$ & $\begin{array}{l}\text { porphyritic/ } \\
\text { pilotaxitic }\end{array}$ & $\begin{array}{l}\text { porphyritic/ } \\
\text { intergranular }\end{array}$ & $\begin{array}{l}\text { porphyritic/ } \\
\text { microgran- } \\
\text { ular }\end{array}$ & $\begin{array}{l}\text { porphyritic/ } \\
\text { intergranular }\end{array}$ & $\begin{array}{l}\text { porphyritic/ } \\
\text { intergranular }\end{array}$ & $\begin{array}{l}\text { porphyritic/ } \\
\text { pilotaxitic }\end{array}$ \\
\hline \multicolumn{10}{|c|}{ Trace element analyses (parts per million) } \\
\hline $\mathrm{Ba}$ & 223 & 285 & 284 & 313 & 300 & 298 & 322 & 309 & 245 \\
\hline $\mathrm{Rb}$ & 23 & 48 & 33 & 44 & 40 & 28 & 44 & 35 & 33 \\
\hline $\mathrm{Sr}$ & 357 & 407 & 424 & 416 & 342 & 417 & 325 & 346 & 379 \\
\hline Y & 19 & 21 & 25 & 26 & 28 & 29 & 41 & 26 & 19 \\
\hline $\mathrm{Zr}$ & 115 & 181 & 161 & 217 & 155 & 176 & 205 & 157 & 121 \\
\hline $\mathrm{Nb}$ & 5.3 & 7.1 & 8.4 & 10.1 & 7.6 & 12.8 & 10.5 & 7.7 & 6.1 \\
\hline $\mathrm{Ni}$ & 14 & 48 & 14 & 32 & 10 & 44 & 4 & 34 & 12 \\
\hline $\mathrm{Cu}$ & 115 & 89 & 65 & 125 & 57 & 89 & 89 & 72 & 87 \\
\hline $\mathrm{Zn}$ & 88 & 67 & 77 & 83 & 87 & 90 & 95 & 85 & 77 \\
\hline $\mathrm{Cr}$ & 32 & 149 & 17 & 54 & 23 & 70 & 13 & 62 & 22 \\
\hline $\mathrm{Sc}$ & 20 & 25 & 20 & 20 & 22 & 23 & 26 & 23 & 20 \\
\hline $\mathrm{V}$ & 182 & 179 & 132 & 175 & 176 & 161 & 196 & 176 & 160 \\
\hline
\end{tabular}


Table 1. Chemical and modal analyses of igneous rocks of the ancestral Cascade volcanic arc, Beacon Rock 7.5' quadrangle, Skamania County, Washington.-Continued

\begin{tabular}{|c|c|c|c|c|c|c|c|c|c|}
\hline Map No. & 46 & 47 & 48 & 49 & 50 & 51 & 52 & 53 & 54 \\
\hline Field sample No. & 02BV-G52B & 06BV-G579 & 09BV-G1276 & 02BV-G15 & 06BV-G625 & 05BV-G441 & 05BV-G435 & 09BV-G1338 & 02BV-G812 \\
\hline Latitude (N) & $45^{\circ} 43.330^{\prime}$ & $45^{\circ} 43.450^{\prime}$ & $45^{\circ} 42.875^{\prime}$ & $45^{\circ} 44.067^{\prime}$ & $45^{\circ} 41.099^{\prime}$ & $45^{\circ} 42.268^{\prime}$ & $45^{\circ} 41.550^{\prime}$ & $45^{\circ} 42.055^{\prime}$ & $45^{\circ} 41.517^{\prime}$ \\
\hline Longitude (W) & $122^{\circ} 03.660^{\prime}$ & $122^{\circ} 01.285^{\prime}$ & $122^{\circ} 02.492^{\prime}$ & $122^{\circ} 01.431^{\prime}$ & $122^{\circ} 05.351^{\prime}$ & $122^{\circ} 00.898^{\prime}$ & $122^{\circ} 01.020^{\prime}$ & $122^{\circ} 03.318^{\prime}$ & $122^{\circ} 04.940^{\prime}$ \\
\hline Map unit & Tha & Tha & Tha & Tha & Tha & Tha & Tha & Tha & Tha \\
\hline Rock type & Andesite & Andesite & Andesite & Andesite & Andesite & Andesite & Andesite & Andesite & Andesite \\
\hline \multicolumn{10}{|c|}{ Analyses as reported (weight percent) } \\
\hline $\mathrm{SiO}_{2}$ & 58.03 & 56.88 & 57.11 & 58.29 & 57.62 & 56.85 & 57.24 & 57.78 & 58.60 \\
\hline $\mathrm{TiO}_{2}^{2}$ & 1.01 & 0.97 & 1.44 & 1.18 & 1.18 & 1.73 & 1.45 & 1.20 & 1.02 \\
\hline $\mathrm{Al}_{2} \mathrm{O}_{3}$ & 18.57 & 16.22 & 16.06 & 17.13 & 17.15 & 15.71 & 15.95 & 16.64 & 17.42 \\
\hline $\mathrm{FeO}^{*}$ & 6.64 & 6.95 & 7.64 & 7.06 & 7.08 & 8.20 & 7.65 & 7.25 & 6.62 \\
\hline $\mathrm{MnO}$ & 0.12 & 0.11 & 0.13 & 0.14 & 0.11 & 0.14 & 0.14 & 0.15 & 0.11 \\
\hline $\mathrm{MgO}$ & 3.00 & 4.51 & 3.24 & 3.72 & 3.06 & 2.20 & 3.13 & 3.42 & 2.80 \\
\hline $\mathrm{CaO}$ & 7.36 & 7.01 & 6.39 & 6.86 & 6.89 & 6.16 & 6.38 & 6.48 & 6.58 \\
\hline $\mathrm{Na}_{2} \mathrm{O}$ & 3.95 & 3.20 & 3.70 & 3.47 & 3.97 & 3.99 & 3.70 & 3.46 & 4.11 \\
\hline $\mathrm{K}_{2} \mathrm{O}$ & 1.09 & 1.79 & 1.75 & 1.61 & 1.22 & 1.72 & 1.71 & 1.78 & 1.18 \\
\hline $\mathrm{P}_{2} \mathrm{O}_{5}$ & 0.18 & 0.15 & 0.29 & 0.22 & 0.20 & 0.42 & 0.29 & 0.21 & 0.20 \\
\hline Total & 99.96 & 97.80 & 97.75 & 99.68 & 98.49 & 97.12 & 97.63 & 98.37 & 98.64 \\
\hline \multicolumn{10}{|c|}{ Analyses recalculated volatile-free and normalized to $100 \%$ with all $\mathrm{Fe}$ as $\mathrm{FeO}$ (weight percent) } \\
\hline $\mathrm{SiO}_{2}$ & 58.05 & 58.16 & 58.43 & 58.48 & 58.50 & 58.53 & 58.63 & 58.74 & 59.41 \\
\hline $\mathrm{TiO}_{2}^{2}$ & 1.01 & 0.99 & 1.47 & 1.18 & 1.20 & 1.78 & 1.49 & 1.22 & 1.03 \\
\hline $\mathrm{Al}_{2} \mathrm{O}_{3}$ & 18.58 & 16.58 & 16.43 & 17.19 & 17.42 & 16.18 & 16.33 & 16.92 & 17.66 \\
\hline $\mathrm{FeO}^{*}$ & 6.64 & 7.10 & 7.81 & 7.08 & 7.19 & 8.45 & 7.83 & 7.37 & 6.71 \\
\hline $\mathrm{MnO}$ & 0.12 & 0.12 & 0.13 & 0.14 & 0.12 & 0.14 & 0.15 & 0.16 & 0.11 \\
\hline $\mathrm{MgO}$ & 3.00 & 4.61 & 3.31 & 3.73 & 3.11 & 2.27 & 3.20 & 3.47 & 2.84 \\
\hline $\mathrm{CaO}$ & 7.36 & 7.17 & 6.53 & 6.88 & 6.99 & 6.35 & 6.54 & 6.58 & 6.67 \\
\hline $\mathrm{Na}_{2} \mathrm{O}$ & 3.95 & 3.28 & 3.79 & 3.48 & 4.03 & 4.11 & 3.79 & 3.52 & 4.17 \\
\hline $\mathrm{K}_{2} \mathrm{O}$ & 1.09 & 1.83 & 1.79 & 1.62 & 1.24 & 1.77 & 1.75 & 1.81 & 1.19 \\
\hline $\mathrm{P}_{2}^{2} \mathrm{O}_{5}$ & 0.18 & 0.16 & 0.30 & 0.22 & 0.21 & 0.43 & 0.30 & 0.22 & 0.21 \\
\hline $\mathrm{Mg} \#$ & 48.7 & 58.2 & 47.7 & 52.6 & 47.9 & 36.7 & 46.8 & 50.1 & 47.3 \\
\hline \multicolumn{10}{|c|}{ Modes (volume percent) } \\
\hline Plagioclase & 24.9 & 15.8 & 20.5 & 29.0 & 23.4 & 6.8 & 19.6 & 26.9 & 22.5 \\
\hline Clinopyroxene & 1.4 & 3.6 & 2.5 & 4.0 & 4.1 & 0.2 & 2.1 & 3.5 & 3.1 \\
\hline Orthopyroxene & 0.3 & 4.2 & 3.6 & 6.8 & 1.8 & 0.1 & 4.1 & 6.2 & 3.7 \\
\hline Olivine & 0.7 & 1.1 & -- & 0.1 & 0.4 & trace & -- & -- & 1.5 \\
\hline Fe-Ti Oxide & 0.1 & 0.7 & -- & 0.5 & 0.5 & -- & 0.4 & 0.3 & 0.6 \\
\hline Hornblende & -- & -- & -- & -- & -- & -- & -- & -- & -- \\
\hline Biotite & -- & -- & -- & -- & -- & -- & -- & -- & -- \\
\hline Other & -- & -- & -- & -- & -- & -- & -- & -- & -- \\
\hline Groundmass & 72.6 & 74.6 & 73.4 & 59.6 & 69.8 & 92.9 & 73.8 & 63.1 & 68.6 \\
\hline No. points counted & 850 & 850 & 850 & 850 & 850 & 850 & 850 & 850 & 850 \\
\hline $\begin{array}{l}\text { Texture (rock/ } \\
\text { groundmass) }\end{array}$ & $\begin{array}{l}\text { porphyritic/ } \\
\text { intergran- } \\
\text { ular }\end{array}$ & $\begin{array}{l}\text { porphyritic/ } \\
\text { intergranular }\end{array}$ & $\begin{array}{l}\text { porphyritic/ } \\
\text { pilotaxitic }\end{array}$ & $\begin{array}{l}\text { porphyritic/ } \\
\text { intersertal }\end{array}$ & $\begin{array}{l}\text { porphyritic/ } \\
\text { pilotaxitic }\end{array}$ & $\begin{array}{l}\text { porphyritic/ } \\
\text { pilotaxitic }\end{array}$ & $\begin{array}{l}\text { porphyritic/ } \\
\text { microphyric }\end{array}$ & $\begin{array}{c}\text { porphyritic/ } \\
\text { cryptocrys- } \\
\text { talline }\end{array}$ & $\begin{array}{l}\text { porphyritic/ } \\
\text { intergranular }\end{array}$ \\
\hline \multicolumn{10}{|c|}{ Trace element analyses (parts per million) } \\
\hline $\mathrm{Ba}$ & 270 & 307 & 391 & 347 & 300 & 396 & 373 & 375 & 287 \\
\hline $\mathrm{Rb}$ & 30 & 57 & 61 & 43 & 40 & 58 & 60 & 62 & 41 \\
\hline $\mathrm{Sr}$ & 357 & 379 & 320 & 450 & 342 & 352 & 349 & 334 & 353 \\
\hline $\mathrm{Y}$ & 23 & 25 & 34 & 31 & 28 & 40 & 38 & 30 & 24 \\
\hline $\mathrm{Zr}$ & 141 & 208 & 268 & 181 & 155 & 252 & 258 & 264 & 152 \\
\hline $\mathrm{Nb}$ & 8.7 & 7.6 & 14.4 & 9.3 & 7.6 & 13.7 & 12.5 & 13.5 & 7.4 \\
\hline $\mathrm{Ni}$ & 7 & 41 & 47 & 38 & 10 & 11 & 30 & 30 & 12 \\
\hline $\mathrm{Cu}$ & 91 & 102 & 115 & 114 & 57 & 181 & 98 & 75 & 40 \\
\hline $\mathrm{Zn}$ & 80 & 73 & 87 & 83 & 87 & 100 & 95 & 87 & 79 \\
\hline $\mathrm{Cr}$ & 19 & 118 & 87 & 64 & 23 & 6 & 33 & 49 & 26 \\
\hline $\mathrm{Sc}$ & 19 & 23 & 22 & 22 & 22 & 22 & 23 & 21 & 19 \\
\hline V & 162 & 165 & 195 & 164 & 176 & 167 & 175 & 177 & 138 \\
\hline
\end{tabular}

${ }^{2}$ Block in landslide deposit. 
Table 1. Chemical and modal analyses of igneous rocks of the ancestral Cascade volcanic arc, Beacon Rock 7.5' quadrangle, Skamania County, Washington.-Continued

\begin{tabular}{|c|c|c|c|c|c|c|c|c|c|}
\hline Map No. & 55 & 56 & 57 & 58 & 59 & 60 & 61 & 62 & 63 \\
\hline Field sample No. & 08BV-G1065 & 06BV-G577 & 05BV-G448 & 02BV-G11C & 02BV-G63B & 05BV-G427 & 06BV-G797 & 05BV-G432 & 05BV-G4332 \\
\hline Latitude (N) & $45^{\circ} 39.620^{\prime}$ & $45^{\circ} 43.737^{\prime}$ & $45^{\circ} 42.605^{\prime}$ & $45^{\circ} 43.339^{\prime}$ & $45^{\circ} 40.523^{\prime}$ & $45^{\circ} 39.824^{\prime}$ & $45^{\circ} 39.440^{\prime}$ & $45^{\circ} 40.777^{\prime}$ & $45^{\circ} 40.614^{\prime}$ \\
\hline Longitude (W) & $122^{\circ} 03.728^{\prime}$ & $122^{\circ} 01.571^{\prime}$ & $122^{\circ} 01.243^{\prime}$ & $122^{\circ} 03.353^{\prime}$ & $122^{\circ} 03.642^{\prime}$ & $122^{\circ} 01.243^{\prime}$ & $122^{\circ} 01.929^{\prime}$ & $122^{\circ} 01.068^{\prime}$ & $122^{\circ} 00.228^{\prime}$ \\
\hline Map unit & Tha & Tha & Tha & Thd & Thd & Teha & Teha & Teha & Teha \\
\hline Rock type & Andesite & Andesite & Andesite & Dacite & $\begin{array}{c}\text { Dacite } \\
\text { basaltic }\end{array}$ & $\begin{array}{c}\text { Hornblende } \\
\text { basaltic }\end{array}$ & $\begin{array}{c}\text { Hornblende } \\
\text { andesite }\end{array}$ & $\begin{array}{c}\text { Hornblende } \\
\text { andesite }\end{array}$ & Hornblende \\
\hline \multicolumn{10}{|c|}{ Analyses as reported (weight percent) } \\
\hline $\mathrm{SiO}_{2}$ & 59.33 & 60.54 & 61.03 & 65.99 & 67.38 & 54.72 & 56.05 & 56.17 & 56.39 \\
\hline $\mathrm{TiO}_{2}^{2}$ & 1.48 & 1.20 & 1.19 & 0.50 & 0.64 & 1.04 & 1.01 & 1.02 & 1.00 \\
\hline $\mathrm{Al}_{2} \mathrm{O}_{3}$ & 15.47 & 15.76 & 15.34 & 14.78 & 15.04 & 17.79 & 17.86 & 17.50 & 17.39 \\
\hline $\mathrm{FeO}^{2}$ & 7.38 & 6.54 & 7.18 & 5.99 & 3.88 & 7.00 & 6.85 & 6.69 & 6.82 \\
\hline $\mathrm{MnO}$ & 0.18 & 0.09 & 0.17 & 0.08 & 0.05 & 0.13 & 0.14 & 0.13 & 0.17 \\
\hline $\mathrm{MgO}$ & 1.69 & 1.73 & 1.57 & 0.19 & 0.25 & 3.74 & 3.59 & 3.53 & 3.30 \\
\hline $\mathrm{CaO}$ & 4.96 & 5.00 & 4.55 & 1.94 & 1.89 & 8.43 & 8.14 & 7.80 & 7.38 \\
\hline $\mathrm{Na}_{2} \mathrm{O}$ & 4.27 & 4.13 & 4.59 & 5.06 & 4.76 & 3.09 & 3.16 & 3.19 & 3.19 \\
\hline $\mathrm{K}_{2}^{2} \mathrm{O}$ & 1.84 & 1.97 & 1.89 & 2.41 & 2.62 & 1.89 & 1.85 & 1.89 & 1.85 \\
\hline $\mathrm{P}_{2}^{2} \mathrm{O}_{5}$ & 0.39 & 0.32 & 0.46 & 0.12 & 0.13 & 0.30 & 0.28 & 0.26 & 0.26 \\
\hline Total & 96.99 & 97.28 & 97.97 & 97.06 & 96.64 & 98.14 & 98.93 & 98.17 & 97.74 \\
\hline \multicolumn{10}{|c|}{ Analyses recalculated volatile-free and normalized to $100 \%$ with all $\mathrm{Fe}$ as $\mathrm{FeO}$ (weight percent) } \\
\hline $\mathrm{SiO}_{2}$ & 61.17 & 62.23 & 62.30 & 67.99 & 69.72 & 55.76 & 56.66 & 57.21 & 57.69 \\
\hline $\mathrm{TiO}_{2}^{2}$ & 1.53 & 1.23 & 1.21 & 0.52 & 0.66 & 1.06 & 1.02 & 1.04 & 1.02 \\
\hline $\mathrm{Al}_{2} \mathrm{O}_{3}$ & 15.95 & 16.20 & 15.66 & 15.23 & 15.57 & 18.12 & 18.06 & 17.82 & 17.79 \\
\hline $\mathrm{FeO}^{*}$ & 7.60 & 6.72 & 7.33 & 6.17 & 4.02 & 7.14 & 6.92 & 6.81 & 6.98 \\
\hline $\mathrm{MnO}$ & 0.19 & 0.09 & 0.17 & 0.09 & 0.05 & 0.13 & 0.14 & 0.13 & 0.17 \\
\hline $\mathrm{MgO}$ & 1.74 & 1.77 & 1.60 & 0.19 & 0.26 & 3.81 & 3.63 & 3.60 & 3.38 \\
\hline $\mathrm{CaO}$ & 5.12 & 5.14 & 4.64 & 2.00 & 1.95 & 8.59 & 8.23 & 7.95 & 7.55 \\
\hline $\mathrm{Na}_{2} \mathrm{O}$ & 4.40 & 4.25 & 4.69 & 5.21 & 4.92 & 3.15 & 3.20 & 3.25 & 3.26 \\
\hline $\mathrm{K}_{2} \mathrm{O}$ & 1.90 & 2.02 & 1.92 & 2.48 & 2.71 & 1.93 & 1.87 & 1.92 & 1.89 \\
\hline $\mathrm{P}_{2} \mathrm{O}_{5}$ & 0.40 & 0.33 & 0.47 & 0.12 & 0.14 & 0.31 & 0.28 & 0.26 & 0.26 \\
\hline $\mathrm{Mg} \#$ & 33.1 & 36.3 & 31.9 & 6.3 & 12.3 & 53.3 & 52.6 & 53.0 & 50.9 \\
\hline \multicolumn{10}{|c|}{ Modes (volume percent) } \\
\hline Plagioclase & 0.3 & 16.6 & 0.6 & 10.2 & 8.4 & 12.0 & 11.6 & 10.2 & 14.1 \\
\hline Clinopyroxene & 0.1 & 1.5 & trace & -- & -- & 0.3 & 1.0 & 0.8 & 1.2 \\
\hline Orthopyroxene & -- & 1.2 & trace & 1.0 & 1.3 & 1.5 & 1.4 & 1.5 & 2.9 \\
\hline Olivine & -- & trace & 0.1 & -- & -- & -- & -- & -- & -- \\
\hline Fe-Ti Oxide & -- & 0.5 & trace & -- & 0.3 & 0.1 & 0.3 & 0.5 & 0.6 \\
\hline Hornblende & -- & -- & -- & -- & -- & 1.0 & 0.6 & 1.0 & 0.5 \\
\hline Biotite & -- & -- & -- & -- & -- & -- & -- & -- & -- \\
\hline Other & -- & -- & -- & -- & -- & 0.2 & 0.8 & 0.6 & 1.0 \\
\hline Groundmass & 99.6 & 80.2 & 99.3 & 88.8 & 90.0 & 84.9 & 84.3 & 85.4 & 79.7 \\
\hline No. points counted & 850 & 850 & 850 & 850 & 800 & 850 & 850 & 850 & 850 \\
\hline $\begin{array}{l}\text { Texture (rock/ } \\
\text { groundmass) }\end{array}$ & $\begin{array}{l}\text { porphyritic/ } \\
\text { intergran- } \\
\text { ular } \\
\end{array}$ & $\begin{array}{l}\text { porphyritic/ } \\
\text { pilotaxitic }\end{array}$ & $\begin{array}{l}\text { aphyric } \\
\text { pilotaxitic }\end{array}$ & $\begin{array}{l}\text { porphyritic/ } \\
\text { micropoikil- } \\
\text { itic }\end{array}$ & $\begin{array}{l}\text { porphyritic/ } \\
\text { micropoikil- } \\
\text { itic }\end{array}$ & $\begin{array}{l}\text { porphyritic/ } \\
\text { pilotaxitic }\end{array}$ & $\begin{array}{l}\text { porphyritic/ } \\
\text { pilotaxitic }\end{array}$ & $\begin{array}{l}\text { porphyritic/ } \\
\text { pilotaxitic }\end{array}$ & $\begin{array}{l}\text { porphyritic/ } \\
\text { pilotaxitic }\end{array}$ \\
\hline \multicolumn{10}{|c|}{ Trace element analyses (parts per million) } \\
\hline $\mathrm{Ba}$ & 403 & 420 & 434 & 572 & 611 & 685 & 618 & 571 & 611 \\
\hline $\mathrm{Rb}$ & 81 & 68 & 60 & 77 & 81 & 28 & 29 & 30 & 33 \\
\hline $\mathrm{Sr}$ & 303 & 286 & 300 & 183 & 167 & 1252 & 1157 & 1123 & 1060 \\
\hline $\mathrm{Y}$ & 39 & 36 & 45 & 47 & 47 & 19 & 20 & 17 & 18 \\
\hline $\mathrm{Zr}$ & 274 & 292 & 301 & 346 & 371 & 150 & 150 & 145 & 150 \\
\hline $\mathrm{Nb}$ & 15.6 & 14.3 & 16.3 & 16.2 & 19.6 & 4.6 & 4.5 & 5.3 & 5.0 \\
\hline $\mathrm{Ni}$ & 0 & 4 & 6 & 0 & 0 & 28 & 25 & 28 & 28 \\
\hline $\mathrm{Cu}$ & 36 & 92 & 28 & 29 & 26 & 74 & 69 & 62 & 82 \\
\hline $\mathrm{Zn}$ & 100 & 91 & 101 & 104 & 96 & 75 & 65 & 74 & 77 \\
\hline $\mathrm{Cr}$ & 0 & 10 & 1 & 2 & 1 & 28 & 25 & 30 & 28 \\
\hline $\mathrm{Sc}$ & 23 & 19 & 20 & 12 & 11 & 18 & 18 & 17 & 17 \\
\hline $\mathrm{V}$ & 109 & 102 & 44 & 8 & 18 & 177 & 170 & 174 & 166 \\
\hline
\end{tabular}

${ }^{2}$ Block in landslide deposit. 
Table 1. Chemical and modal analyses of igneous rocks of the ancestral Cascade volcanic arc, Beacon Rock 7.5' quadrangle, Skamania County, Washington.-Continued

\begin{tabular}{|c|c|c|c|c|c|c|c|c|c|}
\hline Map No. & 64 & 65 & 66 & 67 & 68 & 69 & 70 & 71 & 72 \\
\hline Field sample No. & 04BV-G281A & 11BV-G1555 & 08BV-G117933 & 05BV-G405A & 05BV-G409 & 06BV-G599 & 05BV-G440A ${ }^{3}$ & 02BV-G61 & 02BV-G074 \\
\hline Latitude (N) & $45^{\circ} 38.535^{\prime}$ & $45^{\circ} 38.518^{\prime}$ & $45^{\circ} 41.691^{\prime}$ & $45^{\circ} 40.796^{\prime}$ & $45^{\circ} 40.305^{\prime}$ & $45^{\circ} 43.463^{\prime}$ & $45^{\circ} 41.882^{\prime}$ & $45^{\circ} 40.893^{\prime}$ & $45^{\circ} 41.011^{\prime}$ \\
\hline Longitude (W) & $122^{\circ} 00.919^{\prime}$ & $122^{\circ} 00.830^{\prime}$ & $122^{\circ} 00.232^{\prime}$ & $122^{\circ} 04.514^{\prime}$ & $122^{\circ} 02.928^{\prime}$ & $122^{\circ} 02.522^{\prime}$ & $122^{\circ} 00.278^{\prime}$ & $122^{\circ} 03.789^{\prime}$ & $122^{\circ} 05.062^{\prime}$ \\
\hline Map unit & Teha & Teha & Tepa & Tepa & Tepa & Tepa & Tepa & Tehd & Tecu \\
\hline Rock type & $\begin{array}{l}\text { Hornblende } \\
\text { andesite }\end{array}$ & $\begin{array}{l}\text { Hornblende } \\
\text { andesite }\end{array}$ & $\begin{array}{l}\text { Hbl-Pyx } \\
\text { andesite }\end{array}$ & $\begin{array}{l}\text { Pyroxene } \\
\text { andesite }\end{array}$ & $\begin{array}{l}\text { Pyroxene } \\
\text { andesite }\end{array}$ & $\begin{array}{l}\text { Pyroxene } \\
\text { andesite }\end{array}$ & $\begin{array}{l}\text { Pyroxene } \\
\text { andesite }\end{array}$ & $\begin{array}{l}\text { Hornblende } \\
\text { dacite }\end{array}$ & $\begin{array}{c}\text { Hbl-Pyx } \\
\text { andesite }\end{array}$ \\
\hline \multicolumn{10}{|c|}{ Analyses as reported (weight percent) } \\
\hline $\mathrm{SiO}_{2}$ & 57.59 & 57.51 & 55.08 & 58.55 & 58.20 & 59.49 & 59.69 & 63.85 & 59.34 \\
\hline $\mathrm{TiO}_{2}^{2}$ & 0.98 & 0.99 & 0.98 & 1.00 & 0.99 & 0.91 & 0.88 & 0.70 & 0.97 \\
\hline $\mathrm{Al}_{2} \mathrm{O}_{3}$ & 17.61 & 17.35 & 18.12 & 16.85 & 16.98 & 16.91 & 16.53 & 17.06 & 17.16 \\
\hline $\mathrm{FeO}^{*}$ & 6.55 & 6.76 & 6.20 & 6.31 & 6.23 & 6.02 & 5.43 & 4.60 & 6.05 \\
\hline $\mathrm{MnO}$ & 0.12 & 0.14 & 0.12 & 0.10 & 0.11 & 0.11 & 0.12 & 0.09 & 0.10 \\
\hline $\mathrm{MgO}$ & 3.54 & 3.09 & 3.42 & 3.82 & 3.31 & 3.39 & 2.65 & 2.68 & 3.92 \\
\hline $\mathrm{CaO}$ & 7.95 & 7.55 & 5.66 & 6.70 & 6.35 & 6.57 & 6.13 & 4.96 & 6.71 \\
\hline $\mathrm{Na}_{2} \mathrm{O}$ & 3.34 & 3.27 & 3.10 & 3.74 & 3.71 & 3.40 & 3.44 & 4.00 & 3.35 \\
\hline $\mathrm{K}_{2} \mathrm{O}$ & 1.33 & 1.74 & 1.37 & 1.37 & 1.39 & 1.98 & 2.10 & 1.69 & 1.91 \\
\hline $\mathrm{P}_{2} \mathrm{O}_{5}$ & 0.22 & 0.21 & 0.19 & 0.17 & 0.17 & 0.17 & 0.17 & 0.16 & 0.17 \\
\hline Total & 99.24 & 98.61 & 94.25 & 98.60 & 97.43 & 98.96 & 97.13 & 99.78 & 99.68 \\
\hline \multicolumn{10}{|c|}{ Analyses recalculated volatile-free and normalized to $100 \%$ with all $\mathrm{Fe}$ as $\mathrm{FeO}$ (weight percent) } \\
\hline $\mathrm{SiO}_{2}$ & 58.03 & 58.32 & 58.44 & 59.38 & 59.74 & 60.12 & 61.45 & 63.99 & 59.53 \\
\hline $\mathrm{TiO}_{2}^{2}$ & 0.99 & 1.01 & 1.04 & 1.01 & 1.01 & 0.92 & 0.91 & 0.70 & 0.97 \\
\hline $\mathrm{Al}_{2} \mathrm{O}_{3}$ & 17.75 & 17.60 & 19.22 & 17.09 & 17.43 & 17.09 & 17.02 & 17.10 & 17.22 \\
\hline $\mathrm{FeO}^{*}$ & 6.60 & 6.85 & 6.58 & 6.40 & 6.39 & 6.09 & 5.59 & 4.61 & 6.07 \\
\hline $\mathrm{MnO}$ & 0.12 & 0.14 & 0.13 & 0.10 & 0.11 & 0.11 & 0.12 & 0.09 & 0.10 \\
\hline $\mathrm{MgO}$ & 3.57 & 3.13 & 3.63 & 3.88 & 3.40 & 3.42 & 2.72 & 2.69 & 3.93 \\
\hline $\mathrm{CaO}$ & 8.01 & 7.66 & 6.00 & 6.79 & 6.52 & 6.64 & 6.31 & 4.97 & 6.73 \\
\hline $\mathrm{Na}_{2} \mathrm{O}$ & 3.37 & 3.32 & 3.29 & 3.79 & 3.81 & 3.44 & 3.55 & 4.01 & 3.36 \\
\hline $\mathrm{K}_{2} \mathrm{O}$ & 1.34 & 1.77 & 1.46 & 1.39 & 1.42 & 2.00 & 2.16 & 1.69 & 1.92 \\
\hline $\mathrm{P}_{2}^{2} \mathrm{O}_{5}$ & 0.22 & 0.22 & 0.20 & 0.17 & 0.17 & 0.18 & 0.18 & 0.16 & 0.17 \\
\hline $\mathrm{Mg} \#$ & 53.3 & 49.3 & 55.1 & 56.3 & 53.4 & 54.4 & 51.3 & 55.1 & 57.7 \\
\hline \multicolumn{10}{|c|}{ Modes (volume percent) } \\
\hline Plagioclase & 16.8 & 17.3 & 15.8 & 17.3 & 18.3 & 13.5 & 18.6 & 12.8 & 14.9 \\
\hline Clinopyroxene & 0.5 & 0.5 & 3.3 & 1.8 & 1.3 & 2.1 & 1.4 & -- & 3.2 \\
\hline Orthopyroxene & 1.4 & 1.4 & 2.9 & 2.4 & 2.3 & 2.2 & 2.1 & -- & 3.5 \\
\hline Olivine & -- & -- & -- & 0.8 & 1.0 & -- & -- & -- & 1.4 \\
\hline Fe-Ti Oxide & 0.3 & 0.3 & 0.5 & 0.2 & 0.3 & 0.6 & 0.4 & 0.4 & 0.4 \\
\hline Hornblende & 1.3 & 0.5 & 0.4 & -- & -- & 0.5 & 0.2 & 8.0 & -- \\
\hline Biotite & -- & -- & - & -- & -- & -- & -- & 0.3 & -- \\
\hline Other & 0.6 & 0.8 & -- & -- & -- & -- & 0.1 & -- & -- \\
\hline Groundmass & 79.1 & 79.2 & 77.1 & 77.5 & 76.8 & 81.1 & 77.2 & 78.5 & 76.6 \\
\hline No. points counted & 850 & 820 & 830 & 850 & 850 & 830 & 850 & 850 & 770 \\
\hline $\begin{array}{l}\text { Texture (rock/ } \\
\text { groundmass) }\end{array}$ & $\begin{array}{l}\text { porphyritic/ } \\
\text { pilotaxitic }\end{array}$ & $\begin{array}{l}\text { porphyritic/ } \\
\text { pilotaxitic }\end{array}$ & $\begin{array}{l}\text { porphyritic/ } \\
\text { pilotaxitic }\end{array}$ & $\begin{array}{l}\text { porphyritic/ } \\
\text { pilotaxitic }\end{array}$ & $\begin{array}{l}\text { porphyritic/ } \\
\text { pilotaxitic }\end{array}$ & $\begin{array}{l}\text { seriate/ } \\
\text { intersertal }\end{array}$ & $\begin{array}{l}\text { seriate/ } \\
\text { intersertal }\end{array}$ & $\begin{array}{l}\text { porphyritic/ } \\
\text { felsitic }\end{array}$ & $\begin{array}{l}\text { seriate/ } \\
\text { intersertal }\end{array}$ \\
\hline \multicolumn{10}{|c|}{ Trace element analyses (parts per million) } \\
\hline $\mathrm{Ba}$ & 455 & 446 & 408 & 303 & 307 & 358 & 377 & 351 & 305 \\
\hline $\mathrm{Rb}$ & 31 & 31 & 28 & 31 & 31 & 44 & 51 & 24 & 35 \\
\hline $\mathrm{Sr}$ & 1035 & 1015 & 602 & 510 & 496 & 694 & 598 & 556 & 479 \\
\hline $\mathrm{Y}$ & 16 & 19 & 24 & 18 & 17 & 22 & 22 & 17 & 19 \\
\hline $\mathrm{Zr}$ & 131 & 138 & 217 & 153 & 152 & 188 & 202 & 121 & 155 \\
\hline $\mathrm{Nb}$ & 3.4 & 6.4 & 7.6 & 7.1 & 6.5 & 6.5 & 7.7 & 8.2 & 8.2 \\
\hline $\mathrm{Ni}$ & 23 & 25 & 25 & 58 & 52 & 23 & 21 & 28 & 53 \\
\hline $\mathrm{Cu}$ & 72 & 67 & 59 & 64 & 143 & 57 & 74 & 40 & 80 \\
\hline $\mathrm{Zn}$ & 74 & 75 & 77 & 76 & 76 & 61 & 65 & 52 & 70 \\
\hline $\mathrm{Cr}$ & 25 & 27 & 34 & 76 & 74 & 34 & 32 & 19 & 78 \\
\hline $\mathrm{Sc}$ & 18 & 16 & 17 & 17 & 17 & 17 & 16 & 14 & 15 \\
\hline $\mathrm{V}$ & 160 & 162 & 150 & 149 & 146 & 141 & 136 & 89 & 144 \\
\hline
\end{tabular}


Table 1. Chemical and modal analyses of igneous rocks of the ancestral Cascade volcanic arc, Beacon Rock 7.5' quadrangle, Skamania County, Washington.-Continued

\begin{tabular}{|c|c|c|c|c|c|c|c|c|c|}
\hline Map No. & 73 & 74 & 75 & 76 & 77 & 78 & 79 & 80 & 81 \\
\hline Field sample No. & 02BV-G04B ${ }^{4}$ & 02BV-G864 & 02BV-G55B ${ }^{5}$ & 03BV-G170 & 02BV-G024 & 02BV-G67A ${ }^{5}$ & 02BV-G875 & 06BV-G655B & 06BV-G786A \\
\hline Latitude (N) & $45^{\circ} 40.316^{\prime}$ & $45^{\circ} 41.285^{\prime}$ & $45^{\circ} 41.376^{\prime}$ & $45^{\circ} 40.968^{\prime}$ & $45^{\circ} 39.061^{\prime}$ & $45^{\circ} 41.192^{\prime}$ & $45^{\circ} 41.377^{\prime}$ & $45^{\circ} 44.049^{\prime}$ & $45^{\circ} 41.680^{\prime}$ \\
\hline Longitude (W) & $122^{\circ} 06.203^{\prime}$ & $122^{\circ} 03.320^{\prime}$ & $122^{\circ} 02.999^{\prime}$ & $122^{\circ} 04.528^{\prime}$ & $122^{\circ} 07.058^{\prime}$ & $122^{\circ} 01.815^{\prime}$ & $122^{\circ} 03.646^{\prime}$ & $122^{\circ} 04.428^{\prime}$ & $122^{\circ} 06.897^{\prime}$ \\
\hline Map unit & Tecu & Tecu & Tecu & Tecu & Tecu & Tecu & Tecu & Tiba & Tiba \\
\hline Rock type & $\begin{array}{c}\text { Pyroxene } \\
\text { andesite }\end{array}$ & $\begin{array}{c}\text { Pyroxene } \\
\text { andesite }\end{array}$ & $\begin{array}{l}\text { Pyroxene } \\
\text { andesite }\end{array}$ & $\begin{array}{l}\text { Pyroxene } \\
\text { andesite }\end{array}$ & $\begin{array}{c}\text { Hornblende } \\
\text { andesite }\end{array}$ & $\begin{array}{c}\text { Pyroxene } \\
\text { dacite }\end{array}$ & $\begin{array}{c}\text { Hornblende } \\
\text { dacite }\end{array}$ & $\begin{array}{l}\text { Basaltic } \\
\text { andesite }\end{array}$ & $\begin{array}{l}\text { Basaltic } \\
\text { andesite }\end{array}$ \\
\hline \multicolumn{10}{|c|}{ Analyses as reported (weight percent) } \\
\hline $\mathrm{SiO}_{2}$ & 59.77 & 59.88 & 58.89 & 61.90 & 60.66 & 62.14 & 69.24 & 52.98 & 52.49 \\
\hline $\mathrm{TiO}_{2}^{2}$ & 0.88 & 0.90 & 0.91 & 0.81 & 0.85 & 0.76 & 0.46 & 1.56 & 1.35 \\
\hline $\mathrm{Al}_{2} \mathrm{O}_{3}$ & 17.46 & 17.30 & 16.79 & 16.70 & 17.59 & 17.03 & 16.83 & 17.53 & 17.57 \\
\hline $\mathrm{FeO}^{*}$ & 5.74 & 6.01 & 6.02 & 5.30 & 5.54 & 4.70 & 3.08 & 9.55 & 9.06 \\
\hline $\mathrm{MnO}$ & 0.09 & 0.10 & 0.10 & 0.09 & 0.08 & 0.08 & 0.06 & 0.17 & 0.22 \\
\hline $\mathrm{MgO}$ & 3.29 & 3.09 & 3.05 & 2.94 & 2.07 & 2.25 & 0.61 & 3.49 & 4.11 \\
\hline $\mathrm{CaO}$ & 6.89 & 6.75 & 6.37 & 6.02 & 5.27 & 5.37 & 1.97 & 9.09 & 8.82 \\
\hline $\mathrm{Na}_{2} \mathrm{O}$ & 3.72 & 3.40 & 3.27 & 3.76 & 3.92 & 3.81 & 3.29 & 3.29 & 3.28 \\
\hline $\mathrm{K}_{2}^{2} \mathrm{O}$ & 1.51 & 1.67 & 1.68 & 1.80 & 1.32 & 1.74 & 2.23 & 0.79 & 0.44 \\
\hline $\mathrm{P}_{2}^{2} \mathrm{O}_{5}$ & 0.15 & 0.15 & 0.15 & 0.14 & 0.19 & 0.18 & 0.09 & 0.21 & 0.21 \\
\hline Total & 99.50 & 99.26 & 97.23 & 99.45 & 97.48 & 98.04 & 97.87 & 98.66 & 97.54 \\
\hline \multicolumn{10}{|c|}{ Analyses recalculated volatile-free and normalized to $100 \%$ with all $\mathrm{Fe}$ as $\mathrm{Fe} 0$ (weight percent) } \\
\hline $\mathrm{SiO}_{2}$ & 60.07 & 60.33 & 60.56 & 62.24 & 62.23 & 63.38 & 70.75 & 53.70 & 53.81 \\
\hline $\mathrm{TiO}_{2}^{2}$ & 0.88 & 0.91 & 0.93 & 0.82 & 0.87 & 0.77 & 0.47 & 1.58 & 1.38 \\
\hline $\mathrm{Al}_{2} \mathrm{O}_{3}$ & 17.55 & 17.43 & 17.27 & 16.79 & 18.04 & 17.37 & 17.20 & 17.77 & 18.01 \\
\hline $\mathrm{FeO}^{*}$ & 5.77 & 6.06 & 6.19 & 5.33 & 5.68 & 4.79 & 3.15 & 9.68 & 9.28 \\
\hline $\mathrm{MnO}$ & 0.09 & 0.10 & 0.11 & 0.09 & 0.08 & 0.08 & 0.06 & 0.17 & 0.22 \\
\hline $\mathrm{MgO}$ & 3.31 & 3.11 & 3.14 & 2.95 & 2.12 & 2.29 & 0.62 & 3.54 & 4.22 \\
\hline $\mathrm{CaO}$ & 6.92 & 6.80 & 6.55 & 6.05 & 5.41 & 5.48 & 2.01 & 9.21 & 9.04 \\
\hline $\mathrm{Na}_{2} \mathrm{O}$ & 3.74 & 3.42 & 3.36 & 3.78 & 4.02 & 3.89 & 3.36 & 3.33 & 3.36 \\
\hline $\mathrm{K}_{2} \mathrm{O}$ & 1.52 & 1.68 & 1.73 & 1.81 & 1.35 & 1.77 & 2.28 & 0.80 & 0.45 \\
\hline $\mathrm{P}_{2} \mathrm{O}_{5}$ & 0.15 & 0.15 & 0.15 & 0.14 & 0.20 & 0.18 & 0.10 & 0.22 & 0.22 \\
\hline $\mathrm{Mg} \#$ & 54.7 & 52.1 & 52.3 & 53.9 & 44.5 & 50.6 & 29.8 & 43.8 & 49.4 \\
\hline \multicolumn{10}{|c|}{ Modes (volume percent) } \\
\hline Plagioclase & 17.9 & 20.4 & 21.9 & 28.0 & 22.4 & 19.3 & 6.4 & 14.1 & 18.5 \\
\hline Clinopyroxene & 1.6 & 1.2 & 1.1 & 1.4 & -- & 0.5 & -- & 0.9 & 1.3 \\
\hline Orthopyroxene & 3.4 & 4.1 & 2.9 & 3.6 & 2.0 & 2.8 & -- & -- & 2.0 \\
\hline Olivine & 1.2 & -- & -- & -- & -- & -- & -- & 0.2 & 0.6 \\
\hline Fe-Ti Oxide & 0.3 & 0.6 & 0.6 & 0.3 & 0.5 & 0.4 & 0.1 & -- & 0.1 \\
\hline Hornblende & -- & 0.4 & 0.5 & 1.1 & 9.0 & 0.1 & 3.8 & -- & -- \\
\hline Biotite & -- & -- & -- & -- & -- & -- & -- & -- & -- \\
\hline Other & -- & 1.0 & 2.5 & -- & -- & -- & 0.4 & -- & -- \\
\hline Groundmass & 75.6 & 72.3 & 70.5 & 65.6 & 66.1 & 76.9 & 89.3 & 84.8 & 77.5 \\
\hline No. points counted & 850 & 850 & 850 & 850 & 830 & 750 & 850 & 850 & 850 \\
\hline $\begin{array}{r}\text { Texture (rock/ } \\
\text { groundmass) }\end{array}$ & $\begin{array}{l}\text { seriate/ } \\
\text { felsitic }\end{array}$ & $\begin{array}{l}\text { seriate/ } \\
\text { pilotaxitic }\end{array}$ & $\begin{array}{l}\text { seriate/ } \\
\text { microphyric }\end{array}$ & $\begin{array}{l}\text { seriate/ } \\
\text { microphyric }\end{array}$ & $\begin{array}{l}\text { seriate/ } \\
\text { microphyric }\end{array}$ & $\begin{array}{l}\text { seriate/ } \\
\text { microphyric }\end{array}$ & $\begin{array}{l}\text { seriate/ } \\
\text { microphyric }\end{array}$ & $\begin{array}{l}\text { seriate/ } \\
\text { intergranular }\end{array}$ & $\begin{array}{l}\text { seriate/ } \\
\text { intersertal }\end{array}$ \\
\hline \multicolumn{10}{|c|}{ Trace element analyses (parts per million) } \\
\hline $\mathrm{Ba}$ & 305 & 336 & 339 & 349 & 412 & 381 & 604 & 208 & 155 \\
\hline $\mathrm{Rb}$ & 32 & 30 & 31 & 40 & 17 & 25 & 44 & 20 & 8 \\
\hline $\mathrm{Sr}$ & 510 & 789 & 738 & 510 & 713 & 494 & 280 & 299 & 313 \\
\hline $\mathrm{Y}$ & 22 & 19 & 19 & 21 & 20 & 13 & 11 & 29 & 32 \\
\hline $\mathrm{Zr}$ & 151 & 131 & 134 & 179 & 123 & 150 & 107 & 136 & 156 \\
\hline $\mathrm{Nb}$ & 8.0 & 5.6 & 5.6 & 7.4 & 7.0 & 9.3 & 10.3 & 6.9 & 7.9 \\
\hline $\mathrm{Ni}$ & 37 & 23 & 20 & 34 & 33 & 22 & 16 & 12 & 16 \\
\hline $\mathrm{Cu}$ & 50 & 89 & 25 & 42 & 47 & 27 & 20 & 167 & 125 \\
\hline $\mathrm{Zn}$ & 61 & 65 & 63 & 61 & 62 & 72 & 39 & 101 & 94 \\
\hline $\mathrm{Cr}$ & 74 & 30 & 30 & 43 & 32 & 29 & 13 & 17 & 27 \\
\hline $\mathrm{Sc}$ & 17 & 15 & 16 & 14 & 12 & 10 & 9 & 33 & 32 \\
\hline $\mathrm{V}$ & 131 & 144 & 147 & 124 & 102 & 91 & 46 & 296 & 229 \\
\hline
\end{tabular}

${ }^{4}$ Block in lahar deposit.

${ }^{5}$ Block in lithic pyroclastic-flow deposit. 
Table 1. Chemical and modal analyses of igneous rocks of the ancestral Cascade volcanic arc, Beacon Rock 7.5' quadrangle, Skamania County, Washington.-Continued

\begin{tabular}{|c|c|c|c|c|c|c|c|c|c|}
\hline Map No. & 82 & 83 & 84 & 85 & 86 & 87 & 88 & 89 & 90 \\
\hline Field sample No. & 02BV-G77 & 06BV-G676 & 06BV-G681 & 06BV-G779 & 03BV-G71A & 07BV-G820 & 06BV-G770A & 06BV-G799 & 06BV-G650 \\
\hline Latitude (N) & $45^{\circ} 44.339^{\prime}$ & $45^{\circ} 40.827^{\prime}$ & $45^{\circ} 40.211^{\prime}$ & $45^{\circ} 41.346^{\prime}$ & $45^{\circ} 42.000^{\prime}$ & $45^{\circ} 44.916^{\prime}$ & $45^{\circ} 43.644^{\prime}$ & $45^{\circ} 41.643^{\prime}$ & $45^{\circ} 44.829^{\prime}$ \\
\hline Longitude (W) & $122^{\circ} 06.364^{\prime}$ & $122^{\circ} 06.472^{\prime}$ & $122^{\circ} 07.297^{\prime}$ & $122^{\circ} 06.519^{\prime}$ & $122^{\circ} 01.673^{\prime}$ & $122^{\circ} 03.753^{\prime}$ & $122^{\circ} 06.269^{\prime}$ & $122^{\circ} 06.082^{\prime}$ & $122^{\circ} 04.654^{\prime}$ \\
\hline Map unit & Tiba & Tiba & Tiah & Tia & Tial & Tqd & Tid & Tid & Tidcr \\
\hline Rock type & $\begin{array}{l}\text { Basaltic } \\
\text { andesite }\end{array}$ & $\begin{array}{l}\text { Basaltic } \\
\text { andesite }\end{array}$ & Andesite & Andesite & $\begin{array}{c}\text { Andesite } \\
\text { quartz diorite } \\
\text { Diorite }\end{array}$ & Pyroxene & Dacite & Dacite & Rhyolite \\
\hline \multicolumn{10}{|c|}{ Analyses as reported (weight percent) } \\
\hline $\mathrm{SiO}_{2}$ & 53.45 & 54.43 & 56.46 & 56.45 & 57.44 & 58.00 & 61.51 & 63.94 & 69.03 \\
\hline $\mathrm{TiO}_{2}^{2}$ & 1.82 & 1.50 & 1.60 & 1.47 & 1.15 & 1.02 & 1.30 & 0.94 & 0.38 \\
\hline $\mathrm{Al}_{2} \mathrm{O}_{3}$ & 15.46 & 16.78 & 16.20 & 15.85 & 17.89 & 17.55 & 14.50 & 14.59 & 14.39 \\
\hline $\mathrm{FeO}^{*}$ & 10.38 & 9.28 & 8.99 & 8.29 & 6.55 & 6.61 & 7.61 & 6.26 & 4.42 \\
\hline $\mathrm{MnO}$ & 0.18 & 0.19 & 0.16 & 0.14 & 0.10 & 0.13 & 0.15 & 0.14 & 0.09 \\
\hline $\mathrm{MgO}$ & 3.69 & 3.46 & 2.75 & 3.16 & 3.48 & 2.55 & 1.65 & 1.23 & 0.26 \\
\hline $\mathrm{CaO}$ & 8.66 & 8.47 & 7.50 & 7.17 & 6.60 & 6.38 & 4.89 & 3.92 & 1.59 \\
\hline $\mathrm{Na}_{2} \mathrm{O}$ & 2.93 & 3.22 & 3.40 & 3.43 & 4.37 & 4.39 & 4.65 & 5.06 & 4.93 \\
\hline $\mathrm{K}_{2}^{2} \mathrm{O}$ & 0.35 & 0.95 & 1.38 & 1.41 & 0.81 & 1.19 & 0.87 & 1.26 & 2.46 \\
\hline $\mathrm{P}_{2}^{2} \mathrm{O}_{5}$ & 0.23 & 0.21 & 0.31 & 0.30 & 0.29 & 0.19 & 0.37 & 0.25 & 0.07 \\
\hline Total & 97.16 & 98.48 & 98.74 & 97.66 & 98.69 & 98.01 & 97.50 & 97.59 & 97.62 \\
\hline \multicolumn{10}{|c|}{ Analyses recalculated volatile-free and normalized to $100 \%$ with all $\mathrm{Fe}$ as $\mathrm{FeO}$ (weight percent) } \\
\hline $\mathrm{SiO}_{2}$ & 55.02 & 55.27 & 57.18 & 57.81 & 58.21 & 59.18 & 63.09 & 65.52 & 70.71 \\
\hline $\mathrm{TiO}_{2}$ & 1.87 & 1.52 & 1.62 & 1.50 & 1.16 & 1.05 & 1.33 & 0.96 & 0.39 \\
\hline $\mathrm{Al}_{2} \mathrm{O}_{3}$ & 15.91 & 17.04 & 16.40 & 16.23 & 18.13 & 17.91 & 14.87 & 14.94 & 14.75 \\
\hline $\mathrm{FeO}^{2}$ & 10.68 & 9.42 & 9.11 & 8.49 & 6.63 & 6.74 & 7.81 & 6.42 & 4.53 \\
\hline $\mathrm{MnO}$ & 0.19 & 0.19 & 0.16 & 0.14 & 0.10 & 0.13 & 0.15 & 0.15 & 0.09 \\
\hline $\mathrm{MgO}$ & 3.80 & 3.51 & 2.78 & 3.23 & 3.53 & 2.60 & 1.69 & 1.26 & 0.26 \\
\hline $\mathrm{CaO}$ & 8.91 & 8.61 & 7.59 & 7.34 & 6.69 & 6.51 & 5.01 & 4.01 & 1.63 \\
\hline $\mathrm{Na}_{2} \mathrm{O}$ & 3.01 & 3.27 & 3.44 & 3.51 & 4.43 & 4.47 & 4.77 & 5.19 & 5.05 \\
\hline $\mathrm{K}_{2} \mathrm{O}$ & 0.36 & 0.96 & 1.40 & 1.44 & 0.82 & 1.21 & 0.89 & 1.30 & 2.52 \\
\hline $\mathrm{P}_{2} \mathrm{O}_{5}$ & 0.24 & 0.21 & 0.31 & 0.31 & 0.29 & 0.19 & 0.38 & 0.26 & 0.07 \\
\hline $\mathrm{Mg} \#$ & 43.4 & 44.3 & 39.4 & 45.0 & 53.0 & 45.2 & 31.8 & 29.7 & 11.1 \\
\hline \multicolumn{10}{|c|}{ Modes (volume percent) } \\
\hline Plagioclase & trace & 15.5 & 31.8 & 11.5 & -- & 24.5 & 0.9 & 6.7 & 14.7 \\
\hline Clinopyroxene & trace & 0.2 & 0.7 & 1.6 & -- & 1.6 & 0.1 & 1.8 & 0.3 \\
\hline Orthopyroxene & -- & -- & 0.3 & 1.5 & -- & 1.5 & 0.1 & 1.3 & 0.7 \\
\hline Olivine & trace & 0.2 & -- & -- & -- & 0.7 & -- & trace & -- \\
\hline Fe-Ti Oxide & -- & -- & -- & -- & -- & 0.4 & 0.1 & 0.2 & 0.1 \\
\hline Hornblende & -- & -- & -- & -- & -- & -- & -- & -- & -- \\
\hline Biotite & -- & -- & -- & -- & -- & -- & -- & -- & -- \\
\hline Other & -- & -- & -- & -- & -- & -- & -- & -- & 1.7 \\
\hline Groundmass & 100.0 & 84.1 & 67.2 & 85.4 & 100.0 & 71.3 & 98.8 & 90.0 & 82.5 \\
\hline No. points counted & -- & 850 & 850 & 850 & -- & 850 & 850 & 850 & 780 \\
\hline $\begin{array}{l}\text { Texture (rock/ } \\
\text { groundmass) }\end{array}$ & $\begin{array}{l}\text { aphyric/ } \\
\text { intergran- } \\
\text { ular }\end{array}$ & $\begin{array}{l}\text { seriate/ } \\
\text { intergranular }\end{array}$ & $\begin{array}{l}\text { porphyritic/ } \\
\text { intersertal }\end{array}$ & $\begin{array}{l}\text { porphyritic/ } \\
\text { intersertal }\end{array}$ & $\begin{array}{l}\text { aphyric/ } \\
\text { pilotaxitic }\end{array}$ & $\begin{array}{l}\text { seriate/ } \\
\text { hypidiomor- } \\
\text { phic }\end{array}$ & $\begin{array}{l}\text { aphyric/ } \\
\text { pilotaxitic }\end{array}$ & $\begin{array}{l}\text { sparsely } \\
\text { phyric/ } \\
\text { pilotaxitic }\end{array}$ & $\begin{array}{l}\text { porphyritic/ } \\
\text { felsitic }\end{array}$ \\
\hline \multicolumn{10}{|c|}{ Trace element analyses (parts per million) } \\
\hline $\mathrm{Ba}$ & 156 & 251 & 345 & 343 & 243 & 295 & 382 & 436 & 625 \\
\hline $\mathrm{Rb}$ & 22 & 30 & 36 & 57 & 13 & 37 & 66 & 84 & 80 \\
\hline $\mathrm{Sr}$ & 443 & 294 & 300 & 273 & 603 & 373 & 241 & 193 & 156 \\
\hline $\mathrm{Y}$ & 27 & 31 & 41 & 40 & 14 & 24 & 45 & 54 & 54 \\
\hline $\mathrm{Zr}$ & 120 & 149 & 231 & 259 & 132 & 155 & 281 & 318 & 357 \\
\hline $\mathrm{Nb}$ & 6.3 & 8.1 & 11.2 & 13.1 & 9.4 & 7.4 & 13.6 & 16.8 & 18.6 \\
\hline $\mathrm{Ni}$ & 7 & 8 & 10 & 21 & 47 & 2 & 1 & 1 & 0 \\
\hline $\mathrm{Cu}$ & 201 & 182 & 163 & 16 & 62 & 66 & 106 & 50 & 20 \\
\hline $\mathrm{Zn}$ & 100 & 95 & 102 & 92 & 98 & 82 & 95 & 93 & 117 \\
\hline $\mathrm{Cr}$ & 12 & 18 & 19 & 29 & 57 & 7 & 3 & 3 & 2 \\
\hline $\mathrm{Sc}$ & 35 & 34 & 28 & 25 & 12 & 20 & 22 & 19 & 16 \\
\hline V & 302 & 274 & 188 & 189 & 128 & 147 & 70 & 44 & 0 \\
\hline
\end{tabular}


Table 1. Chemical and modal analyses of igneous rocks of the ancestral Cascade volcanic arc, Beacon Rock 7.5' quadrangle, Skamania County, Washington.-Continued

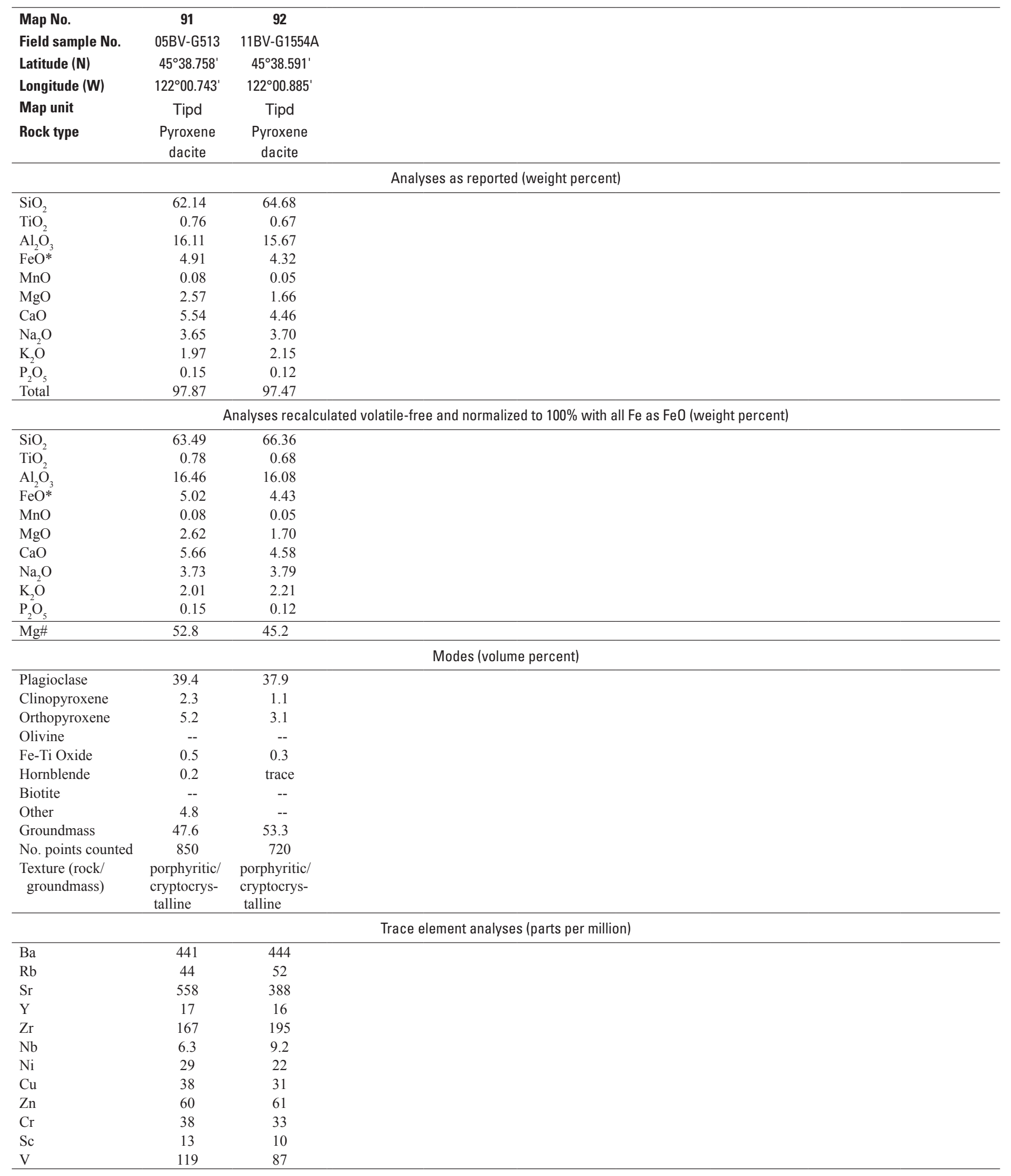


Table 2. Chemical analyses of the Columbia River Basalt Group, Beacon Rock 7.5' quadrangle, Skamania County, Washington.

[X-ray fluorescence analyses. Map No., see figure 16 (sheet 2). Rock-type names assigned in accordance with IUGS system (Le Maitre, 2002) applied to recalculated analyses. $\mathrm{FeO}^{*}$, total Fe calculated as $\mathrm{FeO} ; \mathrm{Mg}$, atomic ratio $100 \mathrm{Mg} /\left(\mathrm{Mg}^{2} \mathrm{Fe}^{2+}\right)$ with $\mathrm{Fe}^{2+}$ set to $0.85 \times \mathrm{Fe}^{\text {total }}$. Analyses by D.M. Johnson Cornelius and R.M. Conrey at Peter Hooper GeoAnalytical Laboratory of Washington State University, Pullman, Washington, using methods described in Johnson and others (1999)].

\begin{tabular}{|c|c|c|c|c|c|c|c|c|c|}
\hline Map No. & 93 & 94 & 95 & 96 & 97 & 98 & 99 & 100 & 101 \\
\hline Field sample No. & 04BV-G323 & 05BV-G510 & 05BV-G403 & 09BV-G1377 & 09BV-G1385 & 05BV-G402 & 04BV-G282A ${ }^{1}$ & 04BV-G283 & 12BV-G1566 \\
\hline Latitude (N) & $45^{\circ} 38.728^{\prime}$ & $45^{\circ} 38.939^{\prime}$ & $45^{\circ} 37.606^{\prime}$ & $45^{\circ} 39.040^{\prime}$ & $45^{\circ} 39.302^{\prime}$ & $45^{\circ} 37.780^{\prime}$ & $45^{\circ} 38.661^{\prime}$ & $45^{\circ} 38.906^{\prime}$ & $45^{\circ} 38.905^{\prime}$ \\
\hline Longitude (W) & $122^{\circ} 01.450^{\prime}$ & $122^{\circ} 00.567^{\prime}$ & $122^{\circ} 06.517^{\prime}$ & $122^{\circ} 01.072^{\prime}$ & $122^{\circ} 00.353^{\prime}$ & $122^{\circ} 06.593^{\prime}$ & $122^{\circ} 00.614^{\prime}$ & $122^{\circ} 00.465^{\prime}$ & $122^{\circ} 00.459^{\prime}$ \\
\hline Map unit & Tgwr & Tgwr & Tgwr & Tgwr & Tgwr & Tggc & Tgo & Tgo & Tgo \\
\hline Rock type & $\begin{array}{l}\text { Basaltic } \\
\text { andesite }\end{array}$ & $\begin{array}{l}\text { Basaltic } \\
\text { andesite }\end{array}$ & $\begin{array}{l}\text { Basaltic } \\
\text { andesite }\end{array}$ & $\begin{array}{l}\text { Basaltic } \\
\text { andesite }\end{array}$ & $\begin{array}{l}\text { Basaltic } \\
\text { andesite }\end{array}$ & $\begin{array}{l}\text { Basaltic } \\
\text { andesite }\end{array}$ & $\begin{array}{l}\text { Basaltic } \\
\text { andesite }\end{array}$ & $\begin{array}{l}\text { Basaltic } \\
\text { andesite }\end{array}$ & $\begin{array}{l}\text { Basaltic } \\
\text { andesite }\end{array}$ \\
\hline \multicolumn{10}{|c|}{ Analyses as reported (weight percent) } \\
\hline $\mathrm{SiO}_{2}$ & 54.83 & 54.51 & 54.08 & 54.38 & 54.55 & 55.33 & 55.30 & 54.76 & 55.17 \\
\hline $\mathrm{TiO}_{2}$ & 2.35 & 2.35 & 2.31 & 2.33 & 2.34 & 1.97 & 1.93 & 1.95 & 1.96 \\
\hline $\mathrm{Al}_{2} \mathrm{O}_{3}$ & 13.34 & 13.43 & 13.23 & 13.41 & 13.37 & 13.80 & 13.66 & 13.64 & 13.71 \\
\hline $\mathrm{FeO}^{*}$ & 12.46 & 12.35 & 12.11 & 12.19 & 12.15 & 11.53 & 11.83 & 11.75 & 10.97 \\
\hline $\mathrm{MnO}$ & 0.20 & 0.20 & 0.19 & 0.20 & 0.19 & 0.19 & 0.19 & 0.19 & 0.19 \\
\hline $\mathrm{MgO}$ & 3.45 & 3.43 & 3.36 & 3.43 & 3.41 & 3.66 & 3.64 & 3.61 & 3.65 \\
\hline $\mathrm{CaO}$ & 7.05 & 7.01 & 6.91 & 7.02 & 7.01 & 7.12 & 7.22 & 7.17 & 7.17 \\
\hline $\mathrm{Na}_{2} \mathrm{O}$ & 3.10 & 3.15 & 3.15 & 3.14 & 3.19 & 3.23 & 3.37 & 3.17 & 3.19 \\
\hline $\mathrm{K}_{2} \mathrm{O}$ & 1.87 & 1.74 & 1.77 & 1.68 & 1.76 & 1.75 & 1.46 & 1.69 & 1.69 \\
\hline $\mathrm{P}_{2} \mathrm{O}_{5}$ & 0.41 & 0.40 & 0.40 & 0.41 & 0.41 & 0.34 & 0.32 & 0.34 & 0.34 \\
\hline Total & 99.07 & 98.56 & 97.52 & 98.20 & 98.38 & 98.93 & 98.91 & 98.27 & 98.04 \\
\hline \multicolumn{10}{|c|}{ Analyses recalculated volatile-free and normalized to $100 \%$ with all $\mathrm{Fe}$ as $\mathrm{Fe} 0$ (weight percent) } \\
\hline $\mathrm{SiO}_{2}$ & 55.35 & 55.30 & 55.45 & 55.38 & 55.45 & 55.93 & 55.91 & 55.72 & 56.27 \\
\hline $\mathrm{TiO}_{2}$ & 2.37 & 2.38 & 2.37 & 2.38 & 2.38 & 1.99 & 1.95 & 1.99 & 2.00 \\
\hline $\mathrm{Al}_{2} \mathrm{O}_{3}$ & 13.47 & 13.63 & 13.57 & 13.65 & 13.59 & 13.95 & 13.81 & 13.88 & 13.98 \\
\hline $\mathrm{FeO}^{*}$ & 12.58 & 12.53 & 12.42 & 12.42 & 12.35 & 11.65 & 11.96 & 11.95 & 11.19 \\
\hline $\mathrm{MnO}$ & 0.20 & 0.20 & 0.20 & 0.20 & 0.20 & 0.19 & 0.19 & 0.19 & 0.19 \\
\hline $\mathrm{MgO}$ & 3.48 & 3.48 & 3.45 & 3.49 & 3.46 & 3.70 & 3.68 & 3.67 & 3.72 \\
\hline $\mathrm{CaO}$ & 7.12 & 7.11 & 7.09 & 7.15 & 7.12 & 7.20 & 7.30 & 7.30 & 7.31 \\
\hline $\mathrm{Na}_{2} \mathrm{O}$ & 3.13 & 3.20 & 3.23 & 3.20 & 3.25 & 3.26 & 3.41 & 3.23 & 3.25 \\
\hline $\mathrm{K}_{2} \mathrm{O}$ & 1.88 & 1.77 & 1.82 & 1.71 & 1.78 & 1.77 & 1.47 & 1.72 & 1.72 \\
\hline $\mathrm{P}_{2} \mathrm{O}_{5}$ & 0.41 & 0.41 & 0.41 & 0.41 & 0.41 & 0.35 & 0.32 & 0.35 & 0.35 \\
\hline $\mathrm{Mg} \#$ & 36.9 & 36.8 & 36.8 & 37.5 & 37.0 & 40.0 & 39.5 & 39.6 & 41.1 \\
\hline \multicolumn{10}{|c|}{ Trace element analyses (parts per million) } \\
\hline $\mathrm{Ba}$ & 698 & 710 & 697 & 693 & 710 & 687 & 655 & 664 & 683 \\
\hline $\mathrm{Rb}$ & 53 & 51 & 51 & 51 & 51 & 49 & 48 & 50 & 50 \\
\hline $\mathrm{Sr}$ & 331 & 329 & 321 & 335 & 332 & 325 & 324 & 330 & 328 \\
\hline Y & 37 & 39 & 37 & 37 & 39 & 36 & 34 & 35 & 35 \\
\hline $\mathrm{Zr}$ & 192 & 186 & 183 & 192 & 191 & 172 & 175 & 177 & 172 \\
\hline $\mathrm{Nb}$ & 14.8 & 13.6 & 13.0 & 14.3 & 14.0 & 12.2 & 12.7 & 12.7 & 11.2 \\
\hline $\mathrm{Ni}$ & 11 & 13 & 13 & 10 & 12 & 13 & 11 & 11 & 10 \\
\hline $\mathrm{Cu}$ & 23 & 20 & 23 & 24 & 23 & 21 & 19 & 24 & 20 \\
\hline $\mathrm{Zn}$ & 132 & 127 & 126 & 132 & 131 & 122 & 122 & 121 & 122 \\
\hline $\mathrm{Cr}$ & 3 & 9 & 9 & 6 & 7 & 14 & 11 & 11 & 12 \\
\hline $\mathrm{Sc}$ & 33 & 31 & 31 & 32 & 31 & 31 & 32 & 31 & 31 \\
\hline $\mathrm{V}$ & 378 & 376 & 372 & 381 & 380 & 333 & 327 & 327 & 328 \\
\hline
\end{tabular}

${ }^{1}$ Clast in pillow breccia. 
Table 2. Chemical analyses of the Columbia River Basalt Group, Beacon Rock 7.5' quadrangle, Skamania County, Washington.-Continued

\begin{tabular}{|c|c|c|c|c|c|c|c|c|c|}
\hline Map No. & 102 & 103 & 104 & 105 & 106 & 107 & 108 & 109 & 110 \\
\hline Field sample No. & 12BV-G1567 & 12BV-G1568 & 08BV-G1211A & 08BV-G1211B 1 & 12BV-G15691 & 12BV-G1570' & 05BV-G429A & 05BV-G429B & 04BV-G322 \\
\hline Latitude (N) & $45^{\circ} 38.879^{\prime}$ & $45^{\circ} 38.864^{\prime}$ & $45^{\circ} 38.892^{\prime}$ & $45^{\circ} 38.902^{\prime}$ & $45^{\circ} 38.790^{\prime}$ & $45^{\circ} 38.633^{\prime}$ & $45^{\circ} 39.517^{\prime}$ & $45^{\circ} 39.561^{\prime}$ & $45^{\circ} 38.822^{\prime}$ \\
\hline Longitude (W) & $122^{\circ} 00.460^{\prime}$ & $122^{\circ} 00.460^{\prime}$ & $122^{\circ} 00.285^{\prime}$ & $122^{\circ} 00.281^{\prime}$ & $122^{\circ} 00.492^{\prime}$ & $122^{\circ} 00.598^{\prime}$ & $122^{\circ} 00.733^{\prime}$ & $122^{\circ} 00.721^{\prime}$ & $122^{\circ} 01.459^{\prime}$ \\
\hline Map unit & Tgo & Tgo & Tgo & Tgo & Tgo & Tgo & Tgo & Tgo & Tgo \\
\hline Rock type & $\begin{array}{l}\text { Basaltic } \\
\text { andesite }\end{array}$ & $\begin{array}{l}\text { Basaltic } \\
\text { andesite }\end{array}$ & $\begin{array}{l}\text { Basaltic } \\
\text { andesite }\end{array}$ & $\begin{array}{l}\text { Basaltic } \\
\text { andesite }\end{array}$ & $\begin{array}{l}\text { Basaltic } \\
\text { andesite }\end{array}$ & $\begin{array}{l}\text { Basaltic } \\
\text { andesite }\end{array}$ & $\begin{array}{l}\text { Basaltic } \\
\text { andesite }\end{array}$ & $\begin{array}{l}\text { Basaltic } \\
\text { andesite }\end{array}$ & $\begin{array}{l}\text { Basaltic } \\
\text { andesite }\end{array}$ \\
\hline \multicolumn{10}{|c|}{ Analyses as reported (weight percent) } \\
\hline $\mathrm{SiO}_{2}$ & 55.45 & 54.98 & 54.08 & 54.39 & 54.49 & 55.37 & 54.81 & 54.39 & 55.36 \\
\hline $\mathrm{TiO}_{2}$ & 1.97 & 2.03 & 1.99 & 1.91 & 1.91 & 1.93 & 1.94 & 1.95 & 1.93 \\
\hline $\mathrm{Al}_{2} \mathrm{O}_{3}$ & 13.81 & 13.66 & 13.64 & 13.68 & 13.54 & 13.67 & 13.70 & 13.59 & 13.65 \\
\hline $\mathrm{FeO}^{*}$ & 11.46 & 11.69 & 11.48 & 11.35 & 11.29 & 11.52 & 11.44 & 11.38 & 11.53 \\
\hline $\mathrm{MnO}$ & 0.19 & 0.19 & 0.20 & 0.19 & 0.19 & 0.19 & 0.19 & 0.19 & 0.19 \\
\hline $\mathrm{MgO}$ & 3.64 & 3.60 & 3.40 & 3.60 & 3.62 & 3.65 & 3.65 & 3.57 & 3.65 \\
\hline $\mathrm{CaO}$ & 7.17 & 7.10 & 7.07 & 7.14 & 7.16 & 7.20 & 7.12 & 7.09 & 7.19 \\
\hline $\mathrm{Na}_{2} \mathrm{O}$ & 3.21 & 3.15 & 3.27 & 3.23 & 3.17 & 3.38 & 3.20 & 3.15 & 3.12 \\
\hline $\mathrm{K}_{2} \mathrm{O}$ & 1.70 & 1.80 & 1.45 & 1.49 & 1.55 & 1.41 & 1.68 & 1.73 & 1.78 \\
\hline $\mathrm{P}_{2} \mathrm{O}_{5}$ & 0.34 & 0.36 & 0.35 & 0.31 & 0.35 & 0.33 & 0.34 & 0.34 & 0.32 \\
\hline Total & 98.94 & 98.56 & 96.92 & 97.29 & 97.27 & 98.65 & 98.07 & 97.38 & 98.73 \\
\hline \multicolumn{10}{|c|}{ Analyses recalculated volatile-free and normalized to $100 \%$ with all $\mathrm{Fe}$ as $\mathrm{Fe} 0$ (weight percent) } \\
\hline $\mathrm{SiO}_{2}$ & 56.04 & 55.78 & 55.80 & 55.90 & 56.02 & 56.13 & 55.89 & 55.85 & 56.07 \\
\hline $\mathrm{TiO}_{2}$ & 1.99 & 2.06 & 2.05 & 1.96 & 1.96 & 1.96 & 1.98 & 2.01 & 1.96 \\
\hline $\mathrm{Al}_{2} \mathrm{O}_{3}$ & 13.96 & 13.86 & 14.07 & 14.06 & 13.92 & 13.86 & 13.97 & 13.96 & 13.83 \\
\hline $\mathrm{FeO} *$ & 11.58 & 11.86 & 11.85 & 11.66 & 11.61 & 11.68 & 11.67 & 11.68 & 11.68 \\
\hline $\mathrm{MnO}$ & 0.19 & 0.19 & 0.21 & 0.20 & 0.20 & 0.19 & 0.19 & 0.19 & 0.19 \\
\hline $\mathrm{MgO}$ & 3.68 & 3.65 & 3.50 & 3.70 & 3.72 & 3.70 & 3.72 & 3.66 & 3.70 \\
\hline $\mathrm{CaO}$ & 7.25 & 7.20 & 7.29 & 7.34 & 7.36 & 7.30 & 7.26 & 7.28 & 7.28 \\
\hline $\mathrm{Na}_{2} \mathrm{O}$ & 3.24 & 3.20 & 3.37 & 3.32 & 3.26 & 3.43 & 3.26 & 3.24 & 3.16 \\
\hline $\mathrm{K}_{2} \mathrm{O}$ & 1.72 & 1.83 & 1.50 & 1.54 & 1.59 & 1.43 & 1.71 & 1.78 & 1.80 \\
\hline $\mathrm{P}_{2} \mathrm{O}_{5}$ & 0.34 & 0.37 & 0.36 & 0.32 & 0.36 & 0.33 & 0.34 & 0.35 & 0.33 \\
\hline $\mathrm{Mg} \#$ & 40.0 & 39.2 & 38.3 & 40.0 & 40.2 & 39.9 & 40.1 & 39.7 & 40.2 \\
\hline \multicolumn{10}{|c|}{ Trace element analyses (parts per million) } \\
\hline $\mathrm{Ba}$ & 677 & 683 & 696 & 643 & 675 & 674 & 671 & 690 & 713 \\
\hline $\mathrm{Rb}$ & 49 & 50 & 46 & 45 & 48 & 49 & 51 & 53 & 47 \\
\hline $\mathrm{Sr}$ & 328 & 324 & 323 & 319 & 321 & 325 & 325 & 316 & 329 \\
\hline $\mathrm{Y}$ & 34 & 35 & 34 & 33 & 33 & 34 & 35 & 35 & 34 \\
\hline $\mathrm{Zr}$ & 175 & 180 & 175 & 171 & 169 & 175 & 177 & 191 & 170 \\
\hline $\mathrm{Nb}$ & 11.4 & 12.7 & 11.1 & 11.4 & 12.1 & 12.5 & 13.3 & 13.7 & 12.1 \\
\hline $\mathrm{Ni}$ & 12 & 12 & 9 & 11 & 14 & 11 & 11 & 9 & 14 \\
\hline $\mathrm{Cu}$ & 23 & 23 & 24 & 18 & 20 & 24 & 19 & 18 & 21 \\
\hline $\mathrm{Zn}$ & 121 & 125 & 126 & 120 & 119 & 123 & 121 & 128 & 120 \\
\hline $\mathrm{Cr}$ & 12 & 10 & 12.7 & 11 & 14 & 12 & 9 & 10 & 14 \\
\hline $\mathrm{Sc}$ & 32 & 32 & 31.5 & 32 & 32 & 31 & 32 & 31 & 32 \\
\hline $\mathrm{V}$ & 332 & 346 & 334.4 & 327 & 329 & 332 & 329 & 328 & 326 \\
\hline
\end{tabular}

${ }^{1}$ Clast in pillow breccia. 
Table 2. Chemical analyses of the Columbia River Basalt Group, Beacon Rock 7.5' quadrangle, Skamania County, Washington.-Continued

\begin{tabular}{|c|c|c|c|c|c|c|c|c|c|}
\hline Map No. & 111 & 112 & 113 & 114 & 115 & 116 & 117 & 118 & 119 \\
\hline Field sample No. & 04BV-G321A & 05BV-G419 & 05BV-G398A & 02BV-G115B-2 & O4BV-G201A & 02BV-G116B & 05BV-G401 & 04BV-G201B & 05BV-G346A \\
\hline Latitude (N) & $45^{\circ} 38.898^{\prime}$ & $45^{\circ} 39.634^{\prime}$ & $45^{\circ} 37.813^{\prime}$ & $45^{\circ} 37.977^{\prime}$ & $45^{\circ} 38.739^{\prime}$ & $45^{\circ} 37.954^{\prime}$ & $45^{\circ} 37.534^{\prime}$ & $45^{\circ} 38.577^{\prime}$ & $45^{\circ} 38.463^{\prime}$ \\
\hline Longitude (W) & $122^{\circ} 01.488^{\prime}$ & $122^{\circ} 02.016^{\prime}$ & $122^{\circ} 06.599^{\prime}$ & $122^{\circ} 06.603^{\prime}$ & $122^{\circ} 06.165^{\prime}$ & $122^{\circ} 06.388^{\prime}$ & $122^{\circ} 06.192^{\prime}$ & $122^{\circ} 06.100^{\prime}$ & $122^{\circ} 06.170^{\prime}$ \\
\hline Map unit & Tgo & Tgo & Tgo & Tgo & Tgo & Tgo & Tgo & Tgo & Tgo \\
\hline Rock type & $\begin{array}{l}\text { Basaltic } \\
\text { andesite }\end{array}$ & $\begin{array}{l}\text { Basaltic } \\
\text { andesite }\end{array}$ & $\begin{array}{l}\text { Basaltic } \\
\text { andesite }\end{array}$ & $\begin{array}{l}\text { Basaltic } \\
\text { andesite }\end{array}$ & $\begin{array}{l}\text { Basaltic } \\
\text { andesite }\end{array}$ & $\begin{array}{l}\text { Basaltic } \\
\text { andesite }\end{array}$ & $\begin{array}{l}\text { Basaltic } \\
\text { andesite }\end{array}$ & $\begin{array}{l}\text { Basaltic } \\
\text { andesite }\end{array}$ & $\begin{array}{l}\text { Basaltic } \\
\text { andesite }\end{array}$ \\
\hline \multicolumn{10}{|c|}{ Analyses as reported (weight percent) } \\
\hline $\mathrm{SiO}_{2}$ & 55.53 & 54.63 & 55.01 & 55.75 & 55.56 & 55.75 & 55.58 & 55.36 & 54.98 \\
\hline $\mathrm{TiO}_{2}$ & 1.99 & 1.94 & 1.90 & 1.83 & 1.88 & 1.95 & 1.91 & 1.98 & 1.99 \\
\hline $\mathrm{Al}_{2} \mathrm{O}_{3}$ & 13.58 & 13.69 & 13.53 & 13.80 & 13.68 & 13.74 & 13.74 & 13.62 & 13.49 \\
\hline $\mathrm{FeO}^{*}$ & 11.87 & 11.09 & 10.96 & 10.88 & 11.62 & 11.17 & 11.05 & 11.26 & 11.34 \\
\hline $\mathrm{MnO}$ & 0.19 & 0.19 & 0.19 & 0.19 & 0.19 & 0.19 & 0.19 & 0.19 & 0.19 \\
\hline $\mathrm{MgO}$ & 3.49 & 3.58 & 3.48 & 3.51 & 3.72 & 3.50 & 3.55 & 3.49 & 3.51 \\
\hline $\mathrm{CaO}$ & 7.06 & 7.09 & 6.97 & 7.10 & 7.26 & 7.04 & 7.07 & 7.01 & 6.87 \\
\hline $\mathrm{Na}_{2} \mathrm{O}$ & 3.12 & 3.20 & 3.13 & 3.10 & 3.06 & 3.15 & 3.15 & 3.19 & 3.33 \\
\hline $\mathrm{K}_{2} \mathrm{O}$ & 1.84 & 1.70 & 1.80 & 1.76 & 1.84 & 1.85 & 1.81 & 1.85 & 1.65 \\
\hline $\mathrm{P}_{2} \mathrm{O}_{5}$ & 0.35 & 0.34 & 0.33 & 0.30 & 0.32 & 0.33 & 0.33 & 0.35 & 0.35 \\
\hline Total & 99.02 & 97.46 & 97.29 & 98.21 & 99.13 & 98.65 & 98.38 & 98.30 & 97.69 \\
\hline \multicolumn{10}{|c|}{ Analyses recalculated volatile-free and normalized to $100 \%$ with all $\mathrm{Fe}$ as $\mathrm{Fe} 0$ (weight percent) } \\
\hline $\mathrm{SiO}_{2}$ & 56.08 & 56.05 & 56.54 & 56.77 & 56.05 & 56.51 & 56.50 & 56.32 & 56.27 \\
\hline $\mathrm{TiO}_{2}$ & 2.01 & 1.99 & 1.95 & 1.86 & 1.90 & 1.97 & 1.94 & 2.02 & 2.03 \\
\hline $\mathrm{Al}_{2} \mathrm{O}_{3}$ & 13.71 & 14.05 & 13.91 & 14.05 & 13.80 & 13.93 & 13.97 & 13.85 & 13.81 \\
\hline $\mathrm{FeO}^{*}$ & 11.98 & 11.38 & 11.26 & 11.08 & 11.72 & 11.32 & 11.23 & 11.45 & 11.61 \\
\hline $\mathrm{MnO}$ & 0.20 & 0.19 & 0.19 & 0.19 & 0.19 & 0.19 & 0.19 & 0.19 & 0.19 \\
\hline $\mathrm{MgO}$ & 3.52 & 3.67 & 3.57 & 3.57 & 3.75 & 3.55 & 3.61 & 3.55 & 3.60 \\
\hline $\mathrm{CaO}$ & 7.13 & 7.28 & 7.16 & 7.23 & 7.32 & 7.14 & 7.19 & 7.14 & 7.03 \\
\hline $\mathrm{Na}_{2} \mathrm{O}$ & 3.16 & 3.29 & 3.22 & 3.15 & 3.09 & 3.19 & 3.21 & 3.24 & 3.41 \\
\hline $\mathrm{K}_{2} \mathrm{O}$ & 1.86 & 1.75 & 1.85 & 1.79 & 1.86 & 1.87 & 1.84 & 1.88 & 1.69 \\
\hline $\mathrm{P}_{2} \mathrm{O}_{5}$ & 0.35 & 0.35 & 0.34 & 0.31 & 0.32 & 0.34 & 0.33 & 0.35 & 0.36 \\
\hline $\mathrm{Mg} \#$ & 38.4 & 40.4 & 39.9 & 40.8 & 40.4 & 40.0 & 40.3 & 39.8 & 39.4 \\
\hline \multicolumn{10}{|c|}{ Trace element analyses (parts per million) } \\
\hline $\mathrm{Ba}$ & 686 & 717 & 670 & 697 & 687 & 694 & 671 & 727 & 670 \\
\hline $\mathrm{Rb}$ & 50 & 49 & 50 & 50 & 50 & 50 & 45 & 48 & 44 \\
\hline $\mathrm{Sr}$ & 306 & 311 & 312 & 312 & 308 & 307 & 299 & 333 & 304 \\
\hline $\mathrm{Y}$ & 36 & 40 & 35 & 33 & 35 & 36 & 35 & 35 & 37 \\
\hline $\mathrm{Zr}$ & 177 & 184 & 183 & 179 & 176 & 181 & 179 & 176 & 179 \\
\hline $\mathrm{Nb}$ & 12.6 & 11.3 & 13.2 & 11.5 & 12.2 & 12.5 & 12.4 & 11.0 & 12.9 \\
\hline $\mathrm{Ni}$ & 11 & 0 & 10 & 16 & 12 & 12 & 13 & 12 & 10 \\
\hline $\mathrm{Cu}$ & 15 & 12 & 13 & 15 & 16 & 18 & 17 & 22 & 14 \\
\hline $\mathrm{Zn}$ & 117 & 122 & 122 & 125 & 119 & 125 & 121 & 124 & 125 \\
\hline $\mathrm{Cr}$ & 13 & 7 & 11 & 16 & 15 & 15 & 14 & 14 & 8 \\
\hline $\mathrm{Sc}$ & 31 & 32 & 31 & 31 & 31 & 30 & 31 & 32 & 31 \\
\hline V & 319 & 305 & 318 & 327 & 322 & 331 & 338 & 340 & 328 \\
\hline
\end{tabular}


Table 2. Chemical analyses of the Columbia River Basalt Group, Beacon Rock 7.5' quadrangle, Skamania County, Washington.-Continued

\begin{tabular}{|c|c|c|c|c|c|c|c|c|c|}
\hline Map No. & 120 & 121 & 122 & 123 & 124 & 125 & 126 & 127 & 128 \\
\hline Field sample No. & 05BV-G346B & 05BV-G349A & 04BV-G153² & 05BV-G508A & 05BV-G508B & 09BV-G1380 & 09BV-G1381 & 04BV-G320A & 04BV-G320B \\
\hline Latitude (N) & $45^{\circ} 38.504^{\prime}$ & $45^{\circ} 38.540^{\prime}$ & $45^{\circ} 38.368^{\prime}$ & $45^{\circ} 38.973^{\prime}$ & $45^{\circ} 39.054^{\prime}$ & $45^{\circ} 39.160^{\prime}$ & $45^{\circ} 39.004^{\prime}$ & $45^{\circ} 39.140^{\prime}$ & $45^{\circ} 39.034^{\prime}$ \\
\hline Longitude (W) & $122^{\circ} 06.080^{\prime}$ & $122^{\circ} 06.141^{\prime}$ & $122^{\circ} 06.694^{\prime}$ & $122^{\circ} 00.339^{\prime}$ & $122^{\circ} 00.315^{\prime}$ & $122^{\circ} 00.419^{\prime}$ & $122^{\circ} 00.304^{\prime}$ & $122^{\circ} 01.523^{\prime}$ & $122^{\circ} 01.521^{\prime}$ \\
\hline Map unit & Tgo & Tgo & Tgo & Tgo & Tgo & Tgo & Tgo & Tgo & Tgo \\
\hline Rock type & $\begin{array}{l}\text { Basaltic } \\
\text { andesite }\end{array}$ & $\begin{array}{l}\text { Basaltic } \\
\text { andesite }\end{array}$ & $\begin{array}{l}\text { Basaltic } \\
\text { andesite }\end{array}$ & $\begin{array}{l}\text { Basaltic } \\
\text { andesite }\end{array}$ & Andesite & $\begin{array}{l}\text { Basaltic } \\
\text { andesite }\end{array}$ & $\begin{array}{l}\text { Basaltic } \\
\text { andesite }\end{array}$ & $\begin{array}{l}\text { Basaltic } \\
\text { andesite }\end{array}$ & $\begin{array}{l}\text { Basaltic } \\
\text { andesite }\end{array}$ \\
\hline \multicolumn{10}{|c|}{ Analyses as reported (weight percent) } \\
\hline $\mathrm{SiO}_{2}$ & 55.04 & 55.50 & 55.15 & 55.68 & 56.49 & 55.58 & 55.94 & 55.71 & 55.44 \\
\hline $\mathrm{TiO}_{2}$ & 2.00 & 1.95 & 1.95 & 1.85 & 1.97 & 1.90 & 1.97 & 1.92 & 1.99 \\
\hline $\mathrm{Al}_{2} \mathrm{O}_{3}$ & 13.84 & 13.43 & 13.47 & 13.64 & 13.85 & 13.64 & 13.63 & 13.69 & 13.48 \\
\hline $\mathrm{FeO}^{*}$ & 11.33 & 11.22 & 11.33 & 10.98 & 10.58 & 11.51 & 11.93 & 11.52 & 11.83 \\
\hline $\mathrm{MnO}$ & 0.19 & 0.18 & 0.20 & 0.19 & 0.16 & 0.17 & 0.19 & 0.19 & 0.19 \\
\hline $\mathrm{MgO}$ & 3.56 & 3.46 & 3.54 & 3.52 & 3.44 & 3.57 & 3.52 & 3.48 & 3.51 \\
\hline $\mathrm{CaO}$ & 7.20 & 6.87 & 7.10 & 7.06 & 6.72 & 6.78 & 7.16 & 7.13 & 6.82 \\
\hline $\mathrm{Na}_{2} \mathrm{O}$ & 3.20 & 3.32 & 3.08 & 3.19 & 3.36 & 3.30 & 3.27 & 3.07 & 3.35 \\
\hline $\mathrm{K}_{2} \mathrm{O}$ & 1.66 & 1.63 & 1.85 & 1.71 & 1.73 & 1.68 & 1.65 & 1.61 & 1.66 \\
\hline $\mathrm{P}_{2} \mathrm{O}_{5}$ & 0.40 & 0.35 & 0.34 & 0.33 & 0.34 & 0.34 & 0.35 & 0.33 & 0.36 \\
\hline Total & 98.42 & 97.90 & 98.02 & 98.15 & 98.63 & 98.48 & 99.61 & 98.65 & 98.63 \\
\hline \multicolumn{10}{|c|}{ Analyses recalculated volatile-free and normalized to $100 \%$ with all $\mathrm{Fe}$ as $\mathrm{Fe} 0$ (weight percent) } \\
\hline $\mathrm{SiO}_{2}$ & 55.92 & 56.69 & 56.27 & 56.72 & 57.27 & 56.43 & 56.15 & 56.48 & 56.21 \\
\hline $\mathrm{TiO}_{2}$ & 2.03 & 1.99 & 1.99 & 1.89 & 2.00 & 1.93 & 1.98 & 1.95 & 2.02 \\
\hline $\mathrm{Al}_{2} \mathrm{O}_{3}$ & 14.06 & 13.72 & 13.74 & 13.90 & 14.04 & 13.85 & 13.69 & 13.87 & 13.67 \\
\hline $\mathrm{FeO}^{*}$ & 11.51 & 11.46 & 11.56 & 11.19 & 10.73 & 11.69 & 11.98 & 11.68 & 12.00 \\
\hline $\mathrm{MnO}$ & 0.20 & 0.18 & 0.20 & 0.19 & 0.16 & 0.18 & 0.19 & 0.19 & 0.19 \\
\hline $\mathrm{MgO}$ & 3.62 & 3.54 & 3.61 & 3.59 & 3.49 & 3.63 & 3.54 & 3.53 & 3.56 \\
\hline $\mathrm{CaO}$ & 7.32 & 7.02 & 7.24 & 7.19 & 6.82 & 6.89 & 7.19 & 7.22 & 6.91 \\
\hline $\mathrm{Na}_{2} \mathrm{O}$ & 3.26 & 3.39 & 3.14 & 3.25 & 3.41 & 3.35 & 3.28 & 3.11 & 3.40 \\
\hline $\mathrm{K}_{2} \mathrm{O}$ & 1.69 & 1.66 & 1.89 & 1.75 & 1.75 & 1.70 & 1.66 & 1.63 & 1.68 \\
\hline $\mathrm{P}_{2} \mathrm{O}_{5}$ & 0.40 & 0.35 & 0.35 & 0.33 & 0.34 & 0.35 & 0.35 & 0.34 & 0.36 \\
\hline $\mathrm{Mg} \#$ & 40.1 & 39.3 & 40.1 & 40.2 & 40.6 & 39.4 & 38.2 & 39.1 & 38.7 \\
\hline \multicolumn{10}{|c|}{ Trace element analyses (parts per million) } \\
\hline $\mathrm{Ba}$ & 667 & 686 & 691 & 670 & 682 & 718 & 673 & 688 & 719 \\
\hline $\mathrm{Rb}$ & 48 & 50 & 49 & 46 & 49 & 45 & 47 & 49 & 50 \\
\hline $\mathrm{Sr}$ & 309 & 311 & 324 & 307 & 318 & 303 & 317 & 309 & 298 \\
\hline Y & 34 & 36 & 36 & 36 & 37 & 37 & 38 & 35 & 35 \\
\hline $\mathrm{Zr}$ & 180 & 181 & 194 & 187 & 189 & 171 & 191 & 176 & 170 \\
\hline $\mathrm{Nb}$ & 12.1 & 12.8 & 12.4 & 13.3 & 14.2 & 12.4 & 14.8 & 12.1 & 11.2 \\
\hline $\mathrm{Ni}$ & 13 & 9 & 8 & 6 & 9 & 5 & 9 & 12 & 6 \\
\hline $\mathrm{Cu}$ & 13 & 12 & 12 & 14 & 16 & 12 & 18 & 17 & 12 \\
\hline $\mathrm{Zn}$ & 123 & 120 & 123 & 124 & 127 & 121 & 129 & 122 & 121 \\
\hline $\mathrm{Cr}$ & 7 & 8 & 6 & 6 & 5 & 8 & 5 & 14 & 12 \\
\hline $\mathrm{Sc}$ & 31 & 33 & 30 & 31 & 32 & 32 & 32 & 31 & 30 \\
\hline $\mathrm{V}$ & 330 & 310 & 312 & 321 & 329 & 323 & 334 & 320 & 321 \\
\hline
\end{tabular}

${ }^{2}$ Float. 
Table 2. Chemical analyses of the Columbia River Basalt Group, Beacon Rock 7.5' quadrangle, Skamania County, Washington.-Continued

\begin{tabular}{|c|c|c|c|c|c|c|c|c|c|}
\hline Map No. & 129 & 130 & 131 & 132 & 133 & 134 & 135 & 136 & 137 \\
\hline Field sample No. & 05BV-G434 & 04BV-G321B & 09BV-G1383 & 05BV-G507 & 05BV-G509 & 09BV-G1378 & 05BV-G418 & 05BV-G430 & 05BV-G439 \\
\hline Latitude (N) & $45^{\circ} 39.843^{\prime}$ & $45^{\circ} 38.952^{\prime}$ & $45^{\circ} 39.000^{\prime}$ & $45^{\circ} 39.374^{\prime}$ & $45^{\circ} 38.950^{\prime}$ & $45^{\circ} 39.228^{\prime}$ & $45^{\circ} 39.665^{\prime}$ & $45^{\circ} 40.181^{\prime}$ & $45^{\circ} 42.684^{\prime}$ \\
\hline Longitude (W) & $122^{\circ} 00.855^{\prime}$ & $122^{\circ} 01.511^{\prime}$ & $122^{\circ} 00.199^{\prime}$ & $122^{\circ} 00.586^{\prime}$ & $122^{\circ} 00.371^{\prime}$ & $122^{\circ} 00.574^{\prime}$ & $122^{\circ} 01.903^{\prime}$ & $122^{\circ} 00.933^{\prime}$ & $122^{\circ} 00.524^{\prime}$ \\
\hline Map unit & Tgo & Tgo & Tgo & Tgo & Tgo & Tgo & Tgo & Tgo & Tgo \\
\hline Rock type & $\begin{array}{l}\text { Basaltic } \\
\text { andesite }\end{array}$ & $\begin{array}{l}\text { Basaltic } \\
\text { andesite }\end{array}$ & $\begin{array}{l}\text { Basaltic } \\
\text { andesite }\end{array}$ & $\begin{array}{l}\text { Basaltic } \\
\text { andesite }\end{array}$ & $\begin{array}{l}\text { Basaltic } \\
\text { andesite }\end{array}$ & $\begin{array}{l}\text { Basaltic } \\
\text { andesite }\end{array}$ & $\begin{array}{l}\text { Basaltic } \\
\text { andesite }\end{array}$ & $\begin{array}{l}\text { Basaltic } \\
\text { andesite }\end{array}$ & $\begin{array}{l}\text { Basaltic } \\
\text { andesite }\end{array}$ \\
\hline \multicolumn{10}{|c|}{ Analyses as reported (weight percent) } \\
\hline $\mathrm{SiO}_{2}$ & 54.94 & 55.96 & 55.69 & 55.75 & 55.73 & 55.57 & 55.31 & 54.50 & 54.91 \\
\hline $\mathrm{TiO}_{2}$ & 1.92 & 1.94 & 1.94 & 1.93 & 1.95 & 1.93 & 1.93 & 1.99 & 1.96 \\
\hline $\mathrm{Al}_{2} \mathrm{O}_{3}$ & 13.57 & 13.65 & 13.68 & 13.73 & 13.80 & 13.66 & 13.69 & 13.51 & 13.73 \\
\hline $\mathrm{FeO}^{*}$ & 11.19 & 11.47 & 11.64 & 11.23 & 10.77 & 11.61 & 11.35 & 11.72 & 10.87 \\
\hline $\mathrm{MnO}$ & 0.19 & 0.19 & 0.19 & 0.19 & 0.19 & 0.19 & 0.18 & 0.20 & 0.19 \\
\hline $\mathrm{MgO}$ & 3.46 & 3.39 & 3.51 & 3.52 & 3.47 & 3.45 & 3.49 & 3.60 & 3.58 \\
\hline $\mathrm{CaO}$ & 6.94 & 6.96 & 7.03 & 7.02 & 7.00 & 7.00 & 7.02 & 7.08 & 7.11 \\
\hline $\mathrm{Na}_{2} \mathrm{O}$ & 3.19 & 3.06 & 3.20 & 3.25 & 3.16 & 3.19 & 3.14 & 3.11 & 3.22 \\
\hline $\mathrm{K}_{2} \mathrm{O}$ & 1.72 & 1.76 & 1.71 & 1.76 & 1.80 & 1.74 & 1.69 & 1.79 & 1.70 \\
\hline $\mathrm{P}_{2} \mathrm{O}_{5}$ & 0.33 & 0.34 & 0.33 & 0.32 & 0.33 & 0.33 & 0.32 & 0.35 & 0.34 \\
\hline Total & 97.45 & 98.70 & 98.92 & 98.70 & 98.20 & 98.66 & 98.13 & 97.86 & 97.59 \\
\hline \multicolumn{10}{|c|}{ Analyses recalculated volatile-free and normalized to $100 \%$ with all $\mathrm{Fe}$ as $\mathrm{FeO}$ (weight percent) } \\
\hline $\mathrm{SiO}_{2}$ & 56.38 & 56.70 & 56.30 & 56.48 & 56.76 & 56.33 & 56.36 & 55.70 & 56.27 \\
\hline $\mathrm{TiO}_{2}$ & 1.97 & 1.96 & 1.96 & 1.95 & 1.99 & 1.96 & 1.97 & 2.03 & 2.00 \\
\hline $\mathrm{Al}_{2} \mathrm{O}_{3}$ & 13.93 & 13.83 & 13.83 & 13.91 & 14.05 & 13.84 & 13.95 & 13.80 & 14.07 \\
\hline $\mathrm{FeO} *$ & 11.48 & 11.62 & 11.77 & 11.38 & 10.96 & 11.76 & 11.57 & 11.98 & 11.14 \\
\hline $\mathrm{MnO}$ & 0.19 & 0.19 & 0.19 & 0.19 & 0.19 & 0.19 & 0.19 & 0.21 & 0.19 \\
\hline $\mathrm{MgO}$ & 3.55 & 3.43 & 3.55 & 3.56 & 3.54 & 3.50 & 3.55 & 3.68 & 3.66 \\
\hline $\mathrm{CaO}$ & 7.12 & 7.06 & 7.11 & 7.11 & 7.13 & 7.10 & 7.16 & 7.24 & 7.28 \\
\hline $\mathrm{Na}_{2} \mathrm{O}$ & 3.28 & 3.10 & 3.24 & 3.29 & 3.21 & 3.23 & 3.20 & 3.18 & 3.29 \\
\hline $\mathrm{K}_{2} \mathrm{O}$ & 1.77 & 1.78 & 1.73 & 1.79 & 1.84 & 1.76 & 1.73 & 1.83 & 1.74 \\
\hline $\mathrm{P}_{2} \mathrm{O}_{5}$ & 0.33 & 0.34 & 0.33 & 0.33 & 0.34 & 0.33 & 0.33 & 0.36 & 0.35 \\
\hline $\mathrm{Mg} \#$ & 39.4 & 38.5 & 38.7 & 39.6 & 40.4 & 38.4 & 39.2 & 39.2 & 40.8 \\
\hline \multicolumn{10}{|c|}{ Trace element analyses (parts per million) } \\
\hline $\mathrm{Ba}$ & 685 & 693 & 723 & 686 & 727 & 674 & 713 & 715 & 669 \\
\hline $\mathrm{Rb}$ & 51 & 50 & 52 & 52 & 50 & 47 & 49 & 54 & 49 \\
\hline $\mathrm{Sr}$ & 312 & 307 & 322 & 312 & 312 & 307 & 328 & 319 & 329 \\
\hline Y & 35 & 35 & 36 & 35 & 36 & 36 & 34 & 36 & 35 \\
\hline $\mathrm{Zr}$ & 185 & 179 & 181 & 185 & 180 & 180 & 171 & 188 & 175 \\
\hline $\mathrm{Nb}$ & 13.1 & 12.7 & 12.4 & 13.0 & 12.2 & 12.7 & 12.4 & 13.9 & 12.4 \\
\hline $\mathrm{Ni}$ & 8 & 12 & 11 & 8 & 10 & 12 & 14 & 10 & 11 \\
\hline $\mathrm{Cu}$ & 17 & 15 & 15 & 15 & 14 & 17 & 22 & 16 & 23 \\
\hline $\mathrm{Zn}$ & 123 & 121 & 123 & 122 & 122 & 125 & 121 & 125 & 122 \\
\hline $\mathrm{Cr}$ & 11 & 14 & 15 & 10 & 14 & 16 & 16 & 11 & 11 \\
\hline $\mathrm{Sc}$ & 31 & 31 & 31 & 31 & 32 & 32 & 32 & 32 & 32 \\
\hline $\mathrm{V}$ & 328 & 322 & 323 & 322 & 324 & 334 & 331 & 328 & 332 \\
\hline
\end{tabular}


Table 2. Chemical analyses of the Columbia River Basalt Group, Beacon Rock 7.5' quadrangle, Skamania County, Washington.-Continued

\begin{tabular}{|c|c|c|c|c|c|c|c|c|c|}
\hline Map No. & 138 & 139 & 140 & 141 & 142 & 143 & 144 & 145 & 146 \\
\hline Field sample No. & 09BV-G1388 & 09BV-G1379A & 09BV-G1379B & 09BV-G1384 & 09BV-G1382 & 09BV-G1376 & 06BV-G572 & 05BV-G417 & 02BV-G115A \\
\hline Latitude (N) & $45^{\circ} 39.185^{\prime}$ & $45^{\circ} 39.234^{\prime}$ & $45^{\circ} 39.235^{\prime}$ & $45^{\circ} 39.197^{\prime}$ & $45^{\circ} 39.007^{\prime}$ & $45^{\circ} 39.085^{\prime}$ & $45^{\circ} 42.748^{\prime}$ & $45^{\circ} 39.639^{\prime}$ & $45^{\circ} 37.962^{\prime}$ \\
\hline Longitude (W) & $122^{\circ} 01.630^{\prime}$ & $122^{\circ} 00.638^{\prime}$ & $122^{\circ} 00.667^{\prime}$ & $122^{\circ} 00.255^{\prime}$ & $122^{\circ} 00.226^{\prime}$ & $122^{\circ} 01.184^{\prime}$ & $122^{\circ} 00.473^{\prime}$ & $122^{\circ} 01.731^{\prime}$ & $122^{\circ} 06.712^{\prime}$ \\
\hline Map unit & Tgo & Tgo & Tgo & Tgo & Tgo & Tgo & Tgo & Tgww & Tgww \\
\hline Rock type & $\begin{array}{l}\text { Basaltic } \\
\text { andesite }\end{array}$ & $\begin{array}{l}\text { Basaltic } \\
\text { andesite }\end{array}$ & $\begin{array}{c}\text { Basaltic } \\
\text { andesite }\end{array}$ & $\begin{array}{l}\text { Basaltic } \\
\text { andesite }\end{array}$ & $\begin{array}{c}\text { Basaltic } \\
\text { andesite }\end{array}$ & $\begin{array}{l}\text { Basaltic } \\
\text { andesite }\end{array}$ & $\begin{array}{l}\text { Basaltic } \\
\text { andesite }\end{array}$ & $\begin{array}{l}\text { Basaltic } \\
\text { andesite }\end{array}$ & $\begin{array}{l}\text { Basaltic } \\
\text { andesite }\end{array}$ \\
\hline \multicolumn{10}{|c|}{ Analyses as reported (weight percent) } \\
\hline $\mathrm{SiO}_{2}$ & 55.93 & 55.25 & 55.15 & 55.73 & 55.69 & 54.43 & 55.11 & 53.71 & 54.35 \\
\hline $\mathrm{TiO}_{2}$ & 1.94 & 1.96 & 1.97 & 1.94 & 2.03 & 2.06 & 1.92 & 2.00 & 2.03 \\
\hline $\mathrm{Al}_{2} \mathrm{O}_{3}$ & 13.76 & 13.75 & 13.76 & 13.82 & 13.54 & 13.52 & 13.49 & 13.43 & 13.58 \\
\hline $\mathrm{FeO}^{*}$ & 11.41 & 11.67 & 11.72 & 11.65 & 11.81 & 12.24 & 11.29 & 12.38 & 12.44 \\
\hline $\mathrm{MnO}$ & 0.19 & 0.19 & 0.19 & 0.19 & 0.18 & 0.20 & 0.19 & 0.20 & 0.21 \\
\hline $\mathrm{MgO}$ & 3.44 & 3.66 & 3.59 & 3.73 & 3.50 & 3.69 & 3.48 & 3.78 & 3.75 \\
\hline $\mathrm{CaO}$ & 7.00 & 7.17 & 7.11 & 7.19 & 6.91 & 7.27 & 7.04 & 7.51 & 7.52 \\
\hline $\mathrm{Na}_{2} \mathrm{O}$ & 3.14 & 3.26 & 3.19 & 3.26 & 3.34 & 3.03 & 3.15 & 3.07 & 3.02 \\
\hline $\mathrm{K}_{2} \mathrm{O}$ & 1.79 & 1.67 & 1.76 & 1.65 & 1.65 & 1.89 & 1.71 & 1.49 & 1.63 \\
\hline $\mathrm{P}_{2} \mathrm{O}_{5}$ & 0.34 & 0.35 & 0.35 & 0.34 & 0.37 & 0.37 & 0.34 & 0.31 & 0.32 \\
\hline Total & 98.80 & 99.50 & 99.01 & 98.70 & 97.71 & 97.89 & 98.84 & 97.97 & 98.28 \\
\hline \multicolumn{10}{|c|}{ Analyses recalculated volatile-free and normalized to $100 \%$ with all $\mathrm{Fe}$ as $\mathrm{Fe} 0$ (weight percent) } \\
\hline $\mathrm{SiO}_{2}$ & 56.53 & 55.85 & 55.82 & 56.02 & 56.24 & 55.15 & 56.40 & 54.87 & 54.99 \\
\hline $\mathrm{TiO}_{2}$ & 1.96 & 1.98 & 2.00 & 1.95 & 2.05 & 2.09 & 1.97 & 2.04 & 2.05 \\
\hline $\mathrm{Al}_{2} \mathrm{O}_{3}$ & 13.90 & 13.90 & 13.93 & 13.89 & 13.68 & 13.70 & 13.81 & 13.72 & 13.74 \\
\hline $\mathrm{FeO}^{*}$ & 11.53 & 11.80 & 11.87 & 11.70 & 11.93 & 12.40 & 11.55 & 12.65 & 12.59 \\
\hline $\mathrm{MnO}$ & 0.19 & 0.19 & 0.19 & 0.19 & 0.18 & 0.20 & 0.20 & 0.21 & 0.21 \\
\hline $\mathrm{MgO}$ & 3.48 & 3.70 & 3.63 & 3.75 & 3.54 & 3.74 & 3.56 & 3.86 & 3.79 \\
\hline $\mathrm{CaO}$ & 7.08 & 7.25 & 7.20 & 7.22 & 6.98 & 7.36 & 7.20 & 7.68 & 7.61 \\
\hline $\mathrm{Na}_{2} \mathrm{O}$ & 3.18 & 3.30 & 3.23 & 3.27 & 3.38 & 3.07 & 3.22 & 3.14 & 3.05 \\
\hline $\mathrm{K}_{2} \mathrm{O}$ & 1.81 & 1.68 & 1.78 & 1.66 & 1.66 & 1.91 & 1.75 & 1.52 & 1.65 \\
\hline $\mathrm{P}_{2} \mathrm{O}_{5}$ & 0.34 & 0.35 & 0.35 & 0.34 & 0.37 & 0.37 & 0.35 & 0.32 & 0.32 \\
\hline $\mathrm{Mg} \#$ & 39.0 & 39.7 & 39.1 & 40.2 & 38.3 & 39.1 & 39.8 & 39.0 & 39.0 \\
\hline \multicolumn{10}{|c|}{ Trace element analyses (parts per million) } \\
\hline $\mathrm{Ba}$ & 692 & 671 & 677 & 654 & 667 & 696 & 656 & 542 & 587 \\
\hline $\mathrm{Rb}$ & 50 & 49 & 46 & 49 & 48 & 46 & 45 & 40 & 40 \\
\hline $\mathrm{Sr}$ & 329 & 329 & 308 & 318 & 313 & 323 & 317 & 309 & 314 \\
\hline Y & 35 & 34 & 37 & 37 & 36 & 34 & 33 & 36 & 35 \\
\hline $\mathrm{Zr}$ & 177 & 175 & 189 & 186 & 181 & 175 & 171 & 170 & 174 \\
\hline $\mathrm{Nb}$ & 13.3 & 13.0 & 13.6 & 13.5 & 12.2 & 11.1 & 10.5 & 12.3 & 12.6 \\
\hline $\mathrm{Ni}$ & 10 & 13 & 9 & 11 & 9 & 9 & 9 & 9 & 14 \\
\hline $\mathrm{Cu}$ & 22 & 23 & 19 & 21 & 15 & 24 & 19 & 9 & 10 \\
\hline $\mathrm{Zn}$ & 123 & 121 & 129 & 128 & 124 & 126 & 121 & 124 & 127 \\
\hline $\mathrm{Cr}$ & 12 & 15 & 12 & 14 & 6 & 13 & 11 & 11 & 12 \\
\hline $\mathrm{Sc}$ & 32 & 33 & 32 & 32 & 33 & 32 & 32 & 35 & 35 \\
\hline V & 331 & 330 & 340 & 363 & 328 & 334 & 329 & 367 & 368 \\
\hline
\end{tabular}


Table 2. Chemical analyses of the Columbia River Basalt Group, Beacon Rock 7.5' quadrangle, Skamania County, Washington.-Continued

\begin{tabular}{|c|c|c|c|c|c|c|c|c|c|}
\hline Map No. & 147 & 148 & 149 & 150 & 151 & 152 & 153 & 154 & 155 \\
\hline Field sample No. & 14BV-G1702B & 05BV-G415 & 05BV-G416 & 02BV-G012 & 05BV-G413 & 05BV-G424B & 06BV-G573 & 06BV-G576 & 14BV-G1702A \\
\hline Latitude (N) & $45^{\circ} 38.623^{\prime}$ & $45^{\circ} 39.961^{\prime}$ & $45^{\circ} 39.715^{\prime}$ & $45^{\circ} 39.000^{\prime}$ & $45^{\circ} 40.371^{\prime}$ & $45^{\circ} 40.655^{\prime}$ & $45^{\circ} 43.171^{\prime}$ & $45^{\circ} 42.666^{\prime}$ & $45^{\circ} 38.614^{\prime}$ \\
\hline Longitude (W) & $122^{\circ} 06.593^{\prime}$ & $122^{\circ} 01.710^{\prime}$ & $122^{\circ} 01.690^{\prime}$ & $122^{\circ} 06.642^{\prime}$ & $122^{\circ} 01.895^{\prime}$ & $122^{\circ} 01.321^{\prime}$ & $122^{\circ} 00.172^{\prime}$ & $122^{\circ} 00.038^{\prime}$ & $122^{\circ} 06.636^{\prime}$ \\
\hline Map unit & Tgww & Tgsb & Tgsb & Tgsb & Tgsb & Tgsb & Tgsb & Tgsb & Tgsb \\
\hline Rock type & $\begin{array}{l}\text { Basaltic } \\
\text { andesite }\end{array}$ & $\begin{array}{l}\text { Basaltic } \\
\text { andesite }\end{array}$ & $\begin{array}{c}\text { Basaltic } \\
\text { andesite }\end{array}$ & $\begin{array}{l}\text { Basaltic } \\
\text { andesite }\end{array}$ & $\begin{array}{c}\text { Basaltic } \\
\text { andesite }\end{array}$ & $\begin{array}{l}\text { Basaltic } \\
\text { andesite }\end{array}$ & $\begin{array}{l}\text { Basaltic } \\
\text { andesite }\end{array}$ & $\begin{array}{l}\text { Basaltic } \\
\text { andesite }\end{array}$ & $\begin{array}{l}\text { Basaltic } \\
\text { andesite }\end{array}$ \\
\hline \multicolumn{10}{|c|}{ Analyses as reported (weight percent) } \\
\hline $\mathrm{SiO}_{2}$ & 54.58 & 52.75 & 52.89 & 53.92 & 53.35 & 52.97 & 52.92 & 53.01 & 53.54 \\
\hline $\mathrm{TiO}_{2}$ & 2.07 & 1.93 & 1.94 & 1.95 & 1.92 & 1.90 & 1.91 & 1.90 & 1.97 \\
\hline $\mathrm{Al}_{2} \mathrm{O}_{3}$ & 13.57 & 13.74 & 13.73 & 14.03 & 13.82 & 13.70 & 13.67 & 13.73 & 14.00 \\
\hline $\mathrm{FeO}^{*}$ & 12.35 & 11.69 & 11.84 & 11.76 & 11.83 & 11.95 & 11.64 & 11.75 & 11.82 \\
\hline $\mathrm{MnO}$ & 0.22 & 0.21 & 0.21 & 0.21 & 0.21 & 0.21 & 0.21 & 0.21 & 0.22 \\
\hline $\mathrm{MgO}$ & 3.73 & 4.73 & 4.75 & 4.77 & 4.79 & 4.75 & 4.73 & 4.78 & 4.66 \\
\hline $\mathrm{CaO}$ & 7.51 & 8.45 & 8.45 & 8.58 & 8.51 & 8.45 & 8.40 & 8.44 & 8.52 \\
\hline $\mathrm{Na}_{2} \mathrm{O}$ & 2.98 & 3.00 & 2.99 & 2.96 & 2.95 & 2.92 & 2.87 & 2.91 & 2.88 \\
\hline $\mathrm{K}_{2} \mathrm{O}$ & 1.70 & 1.16 & 1.15 & 1.25 & 1.18 & 1.15 & 1.24 & 1.12 & 1.25 \\
\hline $\mathrm{P}_{2} \mathrm{O}_{5}$ & 0.33 & 0.32 & 0.32 & 0.29 & 0.28 & 0.28 & 0.29 & 0.28 & 0.29 \\
\hline Total & 99.03 & 97.97 & 98.28 & 99.72 & 98.83 & 98.29 & 97.87 & 98.14 & 99.15 \\
\hline \multicolumn{10}{|c|}{ Analyses recalculated volatile-free and normalized to $100 \%$ with all $\mathrm{Fe}$ as $\mathrm{Fe} 0$ (weight percent) } \\
\hline $\mathrm{SiO}_{2}$ & 55.11 & 53.84 & 53.82 & 54.08 & 53.99 & 53.89 & 54.07 & 54.01 & 54.00 \\
\hline $\mathrm{TiO}_{2}$ & 2.09 & 1.97 & 1.97 & 1.96 & 1.94 & 1.94 & 1.95 & 1.94 & 1.99 \\
\hline $\mathrm{Al}_{2} \mathrm{O}_{3}$ & 13.70 & 14.02 & 13.97 & 14.07 & 13.98 & 13.94 & 13.96 & 13.99 & 14.12 \\
\hline $\mathrm{FeO}^{*}$ & 12.47 & 11.93 & 12.05 & 11.79 & 11.97 & 12.15 & 11.90 & 11.97 & 11.93 \\
\hline $\mathrm{MnO}$ & 0.22 & 0.21 & 0.21 & 0.21 & 0.21 & 0.21 & 0.22 & 0.21 & 0.22 \\
\hline $\mathrm{MgO}$ & 3.76 & 4.83 & 4.83 & 4.79 & 4.84 & 4.83 & 4.83 & 4.87 & 4.70 \\
\hline $\mathrm{CaO}$ & 7.58 & 8.62 & 8.60 & 8.60 & 8.61 & 8.60 & 8.58 & 8.60 & 8.59 \\
\hline $\mathrm{Na}_{2} \mathrm{O}$ & 3.01 & 3.06 & 3.04 & 2.97 & 2.98 & 2.97 & 2.93 & 2.97 & 2.90 \\
\hline $\mathrm{K}_{2} \mathrm{O}$ & 1.72 & 1.19 & 1.17 & 1.25 & 1.19 & 1.17 & 1.27 & 1.14 & 1.26 \\
\hline $\mathrm{P}_{2} \mathrm{O}_{5}$ & 0.33 & 0.33 & 0.33 & 0.29 & 0.29 & 0.29 & 0.30 & 0.29 & 0.29 \\
\hline $\mathrm{Mg \#}$ & 39.0 & 45.9 & 45.7 & 46.1 & 46.2 & 45.5 & 46.5 & 46.5 & 45.5 \\
\hline \multicolumn{10}{|c|}{ Trace element analyses (parts per million) } \\
\hline $\mathrm{Ba}$ & 578 & 524 & 480 & 496 & 453 & 456 & 468 & 456 & 491 \\
\hline $\mathrm{Rb}$ & 41 & 27 & 27 & 28 & 30 & 30 & 30 & 29 & 29 \\
\hline $\mathrm{Sr}$ & 317 & 305 & 306 & 318 & 314 & 311 & 315 & 317 & 321 \\
\hline $\mathrm{Y}$ & 39 & 36 & 36 & 35 & 33 & 34 & 33 & 33 & 54.5 \\
\hline $\mathrm{Zr}$ & 184 & 160 & 159 & 157 & 154 & 155 & 155 & 156 & 164 \\
\hline $\mathrm{Nb}$ & 13.8 & 12.0 & 12.3 & 11.3 & 10.8 & 10.9 & 9.5 & 10.1 & 12.1 \\
\hline $\mathrm{Ni}$ & 5 & 16 & 15 & 20 & 13 & 14 & 13 & 13 & 12 \\
\hline $\mathrm{Cu}$ & 14 & 28 & 27 & 30 & 26 & 27 & 26 & 26 & 29 \\
\hline $\mathrm{Zn}$ & 128 & 118 & 118 & 119 & 114 & 115 & 115 & 115 & 120 \\
\hline $\mathrm{Cr}$ & 8 & 36 & 35 & 25 & 25 & 21 & 22 & 22 & 20 \\
\hline $\mathrm{Sc}$ & 33 & 38 & 38 & 38 & 37 & 37 & 37 & 37 & 37 \\
\hline $\mathrm{V}$ & 367 & 317 & 316 & 342 & 332 & 332 & 332 & 336 & 336 \\
\hline
\end{tabular}

${ }^{2}$ Float. 
Table 2. Chemical analyses of the Columbia River Basalt Group, Beacon Rock 7.5' quadrangle, Skamania County, Washington.-Cotinued

\begin{tabular}{|c|c|c|c|c|c|c|c|c|c|}
\hline Map No. & 156 & 157 & 158 & 159 & 160 & 161 & 162 & 163 & 164 \\
\hline Field sample No. & 05BV-G414 & 05BV-G424A & 02BV-G05-2 & 02BV-G56A & 12BV-G1562 & 12BV-G1563 & 04BV-G202 & 08BV-G1067 & 10BV-G1403 \\
\hline Latitude (N) & $45^{\circ} 40.166^{\prime}$ & $45^{\circ} 40.776^{\prime}$ & $45^{\circ} 40.338^{\prime}$ & $45^{\circ} 41.077^{\prime}$ & $45^{\circ} 41.173^{\prime}$ & $45^{\circ} 41.463^{\prime}$ & $45^{\circ} 38.967^{\prime}$ & $45^{\circ} 37.600^{\prime}$ & $45^{\circ} 37.844^{\prime}$ \\
\hline Longitude (W) & $122^{\circ} 01.809^{\prime}$ & $122^{\circ} 01.401^{\prime}$ & $122^{\circ} 06.090^{\prime}$ & $122^{\circ} 02.475^{\prime}$ & $122^{\circ} 02.387^{\prime}$ & $122^{\circ} 02.592^{\prime}$ & $122^{\circ} 06.212^{\prime}$ & $122^{\circ} 07.310^{\prime}$ & $122^{\circ} 06.786^{\prime}$ \\
\hline Map unit & Tgsb & Tgsb & Tgsb & Tgsb & Tgsb & Tgsb & Tgsb & Tgsb & Tgsb \\
\hline Rock type & $\begin{array}{l}\text { Basaltic } \\
\text { andesite }\end{array}$ & $\begin{array}{l}\text { Basaltic } \\
\text { andesite }\end{array}$ & $\begin{array}{l}\text { Basaltic } \\
\text { andesite }\end{array}$ & $\begin{array}{l}\text { Basaltic } \\
\text { andesite }\end{array}$ & $\begin{array}{l}\text { Basaltic } \\
\text { andesite }\end{array}$ & $\begin{array}{l}\text { Basaltic } \\
\text { andesite }\end{array}$ & $\begin{array}{l}\text { Basaltic } \\
\text { andesite }\end{array}$ & $\begin{array}{l}\text { Basaltic } \\
\text { andesite }\end{array}$ & $\begin{array}{l}\text { Basaltic } \\
\text { andesite }\end{array}$ \\
\hline \multicolumn{10}{|c|}{ Analyses as reported (weight percent) } \\
\hline $\mathrm{SiO}_{2}$ & 53.54 & 52.97 & 54.18 & 54.09 & 54.00 & 54.30 & 54.49 & 52.92 & 53.59 \\
\hline $\mathrm{TiO}_{2}$ & 1.79 & 1.76 & 1.83 & 1.76 & 1.77 & 1.82 & 1.80 & 1.86 & 1.76 \\
\hline $\mathrm{Al}_{2} \mathrm{O}_{3}$ & 14.13 & 14.05 & 14.18 & 14.12 & 14.24 & 14.02 & 14.11 & 14.54 & 13.97 \\
\hline $\mathrm{FeO}^{*}$ & 11.30 & 11.43 & 11.31 & 11.14 & 11.30 & 11.27 & 10.94 & 11.10 & 10.97 \\
\hline $\mathrm{MnO}$ & 0.20 & 0.20 & 0.20 & 0.20 & 0.20 & 0.20 & 0.20 & 0.20 & 0.20 \\
\hline $\mathrm{MgO}$ & 5.10 & 5.13 & 4.48 & 4.82 & 4.80 & 4.65 & 4.54 & 4.32 & 4.66 \\
\hline $\mathrm{CaO}$ & 8.77 & 8.86 & 8.36 & 8.39 & 8.46 & 8.31 & 8.32 & 8.52 & 8.50 \\
\hline $\mathrm{Na}_{2} \mathrm{O}$ & 2.90 & 2.85 & 2.93 & 3.02 & 2.93 & 2.98 & 2.94 & 2.82 & 2.92 \\
\hline $\mathrm{K}_{2} \mathrm{O}$ & 1.23 & 1.08 & 1.41 & 1.31 & 1.27 & 1.38 & 1.43 & 1.18 & 1.35 \\
\hline $\mathrm{P}_{2} \mathrm{O}_{5}$ & 0.28 & 0.27 & 0.36 & 0.32 & 0.33 & 0.35 & 0.35 & 0.35 & 0.32 \\
\hline Total & 99.24 & 98.61 & 99.23 & 99.16 & 99.31 & 99.27 & 99.13 & 97.80 & 98.25 \\
\hline \multicolumn{10}{|c|}{ Analyses recalculated volatile-free and normalized to $100 \%$ with all $\mathrm{Fe}$ as $\mathrm{Fe} 0$ (weight percent) } \\
\hline $\mathrm{SiO}_{2}$ & 53.95 & 53.72 & 54.60 & 54.55 & 54.38 & 54.70 & 54.97 & 54.11 & 54.55 \\
\hline $\mathrm{TiO}_{2}$ & 1.80 & 1.78 & 1.85 & 1.78 & 1.79 & 1.83 & 1.81 & 1.90 & 1.79 \\
\hline $\mathrm{Al}_{2} \mathrm{O}_{3}$ & 14.24 & 14.25 & 14.29 & 14.24 & 14.34 & 14.12 & 14.24 & 14.87 & 14.22 \\
\hline $\mathrm{FeO}^{*}$ & 11.39 & 11.59 & 11.39 & 11.23 & 11.38 & 11.35 & 11.04 & 11.35 & 11.17 \\
\hline $\mathrm{MnO}$ & 0.20 & 0.21 & 0.20 & 0.20 & 0.20 & 0.20 & 0.20 & 0.21 & 0.20 \\
\hline $\mathrm{MgO}$ & 5.13 & 5.20 & 4.52 & 4.86 & 4.84 & 4.68 & 4.58 & 4.41 & 4.75 \\
\hline $\mathrm{CaO}$ & 8.84 & 8.99 & 8.42 & 8.46 & 8.52 & 8.37 & 8.40 & 8.71 & 8.65 \\
\hline $\mathrm{Na}_{2} \mathrm{O}$ & 2.92 & 2.89 & 2.95 & 3.04 & 2.95 & 3.00 & 2.97 & 2.88 & 2.98 \\
\hline $\mathrm{K}_{2} \mathrm{O}$ & 1.24 & 1.10 & 1.42 & 1.33 & 1.28 & 1.39 & 1.45 & 1.21 & 1.37 \\
\hline $\mathrm{P}_{2} \mathrm{O}_{5}$ & 0.28 & 0.27 & 0.36 & 0.32 & 0.33 & 0.36 & 0.36 & 0.36 & 0.33 \\
\hline $\mathrm{Mg} \#$ & 48.6 & 48.5 & 45.6 & 47.8 & 47.3 & 46.6 & 46.7 & 45.5 & 47.6 \\
\hline \multicolumn{10}{|c|}{ Trace element analyses (parts per million) } \\
\hline $\mathrm{Ba}$ & 500 & 441 & 575 & 540 & 534 & 561 & 561 & 634 & 577 \\
\hline $\mathrm{Rb}$ & 29 & 29 & 36 & 33 & 32 & 35 & 34 & 29 & 34 \\
\hline $\mathrm{Sr}$ & 308 & 308 & 321.7 & 310 & 315 & 316 & 300 & 327 & 325 \\
\hline Y & 35 & 32 & 36 & 32 & 39 & 35 & 34 & 43 & 34 \\
\hline $\mathrm{Zr}$ & 153 & 149 & 173 & 161 & 165 & 169 & 156 & 173 & 165 \\
\hline $\mathrm{Nb}$ & 10.7 & 10.3 & 11.8 & 11.7 & 11.1 & 11.5 & 11.1 & 10.9 & 11.1 \\
\hline $\mathrm{Ni}$ & 19 & 19 & 15 & 19 & 15 & 14 & 10 & 11 & 16 \\
\hline $\mathrm{Cu}$ & 35 & 36 & 26 & 25 & 26 & 27 & 23 & 26 & 27 \\
\hline $\mathrm{Zn}$ & 112 & 109 & 124 & 117 & 119 & 120 & 116 & 126 & 118 \\
\hline $\mathrm{Cr}$ & 46 & 46 & 33.8 & 41 & 39 & 34 & 38 & 34 & 35 \\
\hline $\mathrm{Sc}$ & 36 & 37 & 36 & 35 & 35 & 35 & 34 & 37 & 35 \\
\hline $\mathrm{V}$ & 327 & 320 & 299 & 306 & 308 & 299 & 299 & 312 & 310 \\
\hline
\end{tabular}


Table 2. Chemical analyses of the Columbia River Basalt Group, Beacon Rock 7.5' quadrangle, Skamania County, Washington.-Continued

\begin{tabular}{|c|c|c|c|c|c|c|c|c|c|}
\hline Map No. & 165 & 166 & 167 & 168 & 169 & 170 & 171 & 172 & 173 \\
\hline Field sample No. & 06BV-G575 & 06BV-G574A & 05BV-G397 & 06BV-G574B & 10BV-G1402 & O4BV-G198 2 & 09BV-G1308 & 10BV-G1404 & 14BV-G1690A \\
\hline Latitude (N) & $45^{\circ} 42.782^{\prime}$ & $45^{\circ} 43.078^{\prime}$ & $45^{\circ} 37.570^{\prime}$ & $45^{\circ} 42.963^{\prime}$ & $45^{\circ} 37.849^{\prime}$ & $45^{\circ} 38.046^{\prime}$ & $45^{\circ} 37.822^{\prime}$ & $45^{\circ} 37.990^{\prime}$ & $45^{\circ} 38.030^{\prime}$ \\
\hline Longitude (W) & $122^{\circ} 00.076^{\prime}$ & $122^{\circ} 00.034^{\prime}$ & $122^{\circ} 06.917^{\prime}$ & $122^{\circ} 00.128^{\prime}$ & $122^{\circ} 06.824^{\prime}$ & $122^{\circ} 07.150^{\prime}$ & $122^{\circ} 06.857^{\prime}$ & $122^{\circ} 06.836^{\prime}$ & $122^{\circ} 06.994^{\prime}$ \\
\hline Map unit & Tgsb & Tgsb & Twfsh & Twfsh & Twfsh & Twfss & Twfss & Twfss & Twfss \\
\hline Rock type & $\begin{array}{l}\text { Basaltic } \\
\text { andesite }\end{array}$ & $\begin{array}{l}\text { Basaltic } \\
\text { andesite }\end{array}$ & $\begin{array}{l}\text { Basaltic } \\
\text { andesite }\end{array}$ & Basalt & Basalt & $\begin{array}{l}\text { Basaltic } \\
\text { andesite }\end{array}$ & $\begin{array}{l}\text { Basaltic } \\
\text { andesite }\end{array}$ & Basalt & $\begin{array}{l}\text { Basaltic } \\
\text { andesite }\end{array}$ \\
\hline \multicolumn{10}{|c|}{ Analyses as reported (weight percent) } \\
\hline $\mathrm{SiO}_{2}$ & 53.10 & 53.64 & 51.74 & 50.86 & 50.73 & 51.36 & 51.02 & 50.28 & 51.76 \\
\hline $\mathrm{TiO}_{2}$ & 1.73 & 1.80 & 3.03 & 2.95 & 2.93 & 2.96 & 2.96 & 3.04 & 3.02 \\
\hline $\mathrm{Al}_{2} \mathrm{O}_{3}$ & 13.97 & 13.94 & 13.63 & 13.33 & 13.11 & 13.23 & 12.85 & 13.24 & 13.00 \\
\hline $\mathrm{FeO}^{*}$ & 10.75 & 10.97 & 12.39 & 13.31 & 14.15 & 13.91 & 14.30 & 14.31 & 14.47 \\
\hline $\mathrm{MnO}$ & 0.19 & 0.20 & 0.22 & 0.23 & 0.23 & 0.23 & 0.31 & 0.24 & 0.24 \\
\hline $\mathrm{MgO}$ & 4.78 & 4.54 & 4.22 & 4.34 & 4.39 & 3.95 & 3.97 & 4.02 & 4.03 \\
\hline $\mathrm{CaO}$ & 8.37 & 8.26 & 8.47 & 8.22 & 8.25 & 7.91 & 7.84 & 8.01 & 7.95 \\
\hline $\mathrm{Na}_{2} \mathrm{O}$ & 2.82 & 2.88 & 2.85 & 2.74 & 2.77 & 2.76 & 2.82 & 2.87 & 2.85 \\
\hline $\mathrm{K}_{2} \mathrm{O}$ & 1.24 & 1.47 & 1.41 & 1.37 & 1.38 & 1.49 & 1.58 & 1.35 & 1.60 \\
\hline $\mathrm{P}_{2} \mathrm{O}_{5}$ & 0.31 & 0.35 & 0.58 & 0.57 & 0.60 & 0.68 & 0.66 & 0.71 & 0.70 \\
\hline Total & 97.28 & 98.06 & 98.53 & 97.91 & 98.54 & 98.48 & 98.31 & 98.07 & 99.61 \\
\hline \multicolumn{10}{|c|}{ Analyses recalculated volatile-free and normalized to $100 \%$ with all $\mathrm{Fe}$ as $\mathrm{FeO}$ (weight percent) } \\
\hline $\mathrm{SiO}_{2}$ & 54.58 & 54.70 & 52.51 & 51.94 & 51.48 & 52.15 & 51.90 & 51.27 & 51.96 \\
\hline $\mathrm{TiO}_{2}$ & 1.78 & 1.84 & 3.07 & 3.01 & 2.98 & 3.00 & 3.01 & 3.10 & 3.03 \\
\hline $\mathrm{Al}_{2} \mathrm{O}_{3}$ & 14.36 & 14.22 & 13.83 & 13.62 & 13.31 & 13.44 & 13.07 & 13.51 & 13.05 \\
\hline $\mathrm{FeO}^{*}$ & 11.05 & 11.19 & 12.57 & 13.59 & 14.36 & 14.13 & 14.55 & 14.59 & 14.52 \\
\hline $\mathrm{MnO}$ & 0.20 & 0.20 & 0.23 & 0.23 & 0.24 & 0.24 & 0.32 & 0.24 & 0.24 \\
\hline $\mathrm{MgO}$ & 4.92 & 4.63 & 4.28 & 4.43 & 4.45 & 4.01 & 4.03 & 4.10 & 4.05 \\
\hline $\mathrm{CaO}$ & 8.61 & 8.43 & 8.59 & 8.39 & 8.37 & 8.03 & 7.98 & 8.17 & 7.98 \\
\hline $\mathrm{Na}_{2} \mathrm{O}$ & 2.90 & 2.93 & 2.89 & 2.80 & 2.81 & 2.81 & 2.87 & 2.93 & 2.86 \\
\hline $\mathrm{K}_{2} \mathrm{O}$ & 1.28 & 1.50 & 1.44 & 1.40 & 1.40 & 1.51 & 1.60 & 1.37 & 1.61 \\
\hline $\mathrm{P}_{2} \mathrm{O}_{5}$ & 0.32 & 0.36 & 0.59 & 0.58 & 0.61 & 0.69 & 0.67 & 0.72 & 0.70 \\
\hline $\mathrm{Mg \#}$ & 49.0 & 46.9 & 42.0 & 41.1 & 39.8 & 37.7 & 37.2 & 37.5 & 37.0 \\
\hline \multicolumn{10}{|c|}{ Trace element analyses (parts per million) } \\
\hline $\mathrm{Ba}$ & 509 & 556 & 632 & 578 & 551 & 680 & 626 & 724 & 649 \\
\hline $\mathrm{Rb}$ & 33 & 36 & 34 & 34 & 37 & 33 & 41 & 33 & 40 \\
\hline $\mathrm{Sr}$ & 312 & 319 & 322 & 318 & 318 & 300 & 310 & 321 & 315 \\
\hline Y & 32 & 35 & 46 & 43 & 43 & 47 & 46 & 51 & 47 \\
\hline $\mathrm{Zr}$ & 157 & 166 & 195 & 191 & 194 & 197 & 213 & 223 & 220 \\
\hline $\mathrm{Nb}$ & 9.8 & 11.5 & 15.4 & 14.3 & 14.7 & 15.1 & 16.8 & 16.0 & 17.4 \\
\hline $\mathrm{Ni}$ & 15 & 14 & 29 & 22 & 20 & 12 & 18 & 18 & 14 \\
\hline $\mathrm{Cu}$ & 25 & 23 & 28 & 27 & 29 & 18 & 26 & 22 & 25 \\
\hline $\mathrm{Zn}$ & 112 & 117 & 144 & 140 & 143 & 146 & 152 & 161 & 155 \\
\hline $\mathrm{Cr}$ & 39 & 36 & 44 & 40 & 37.3 & 19 & 14 & 14 & 14 \\
\hline $\mathrm{Sc}$ & 35 & 36 & 38 & 37 & 37 & 36 & 37 & 38 & 35 \\
\hline $\mathrm{V}$ & 303 & 296 & 429 & 420 & 416 & 400 & 395 & 400 & 392 \\
\hline
\end{tabular}

${ }^{2}$ Float. 
Table 2. Chemical analyses of the Columbia River Basalt Group, Beacon Rock 7.5' quadrangle, Skamania County, Washington.-Continued

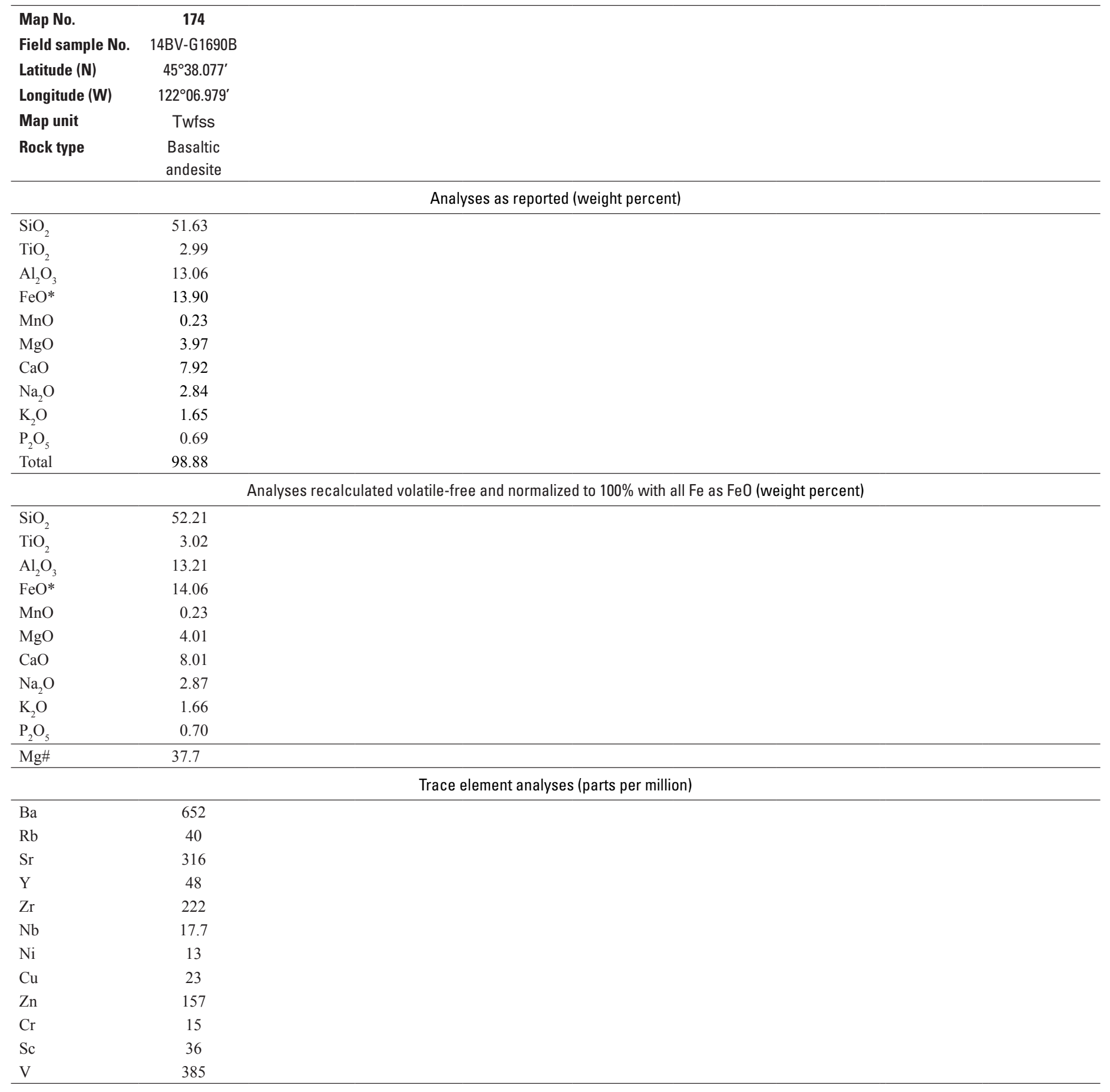


Table 3. Chemical and modal analyses of Quaternary volcanic rocks, Beacon Rock 7.5' quadrangle, Skamania County, Washington.

[X-ray fluorescence analyses. Map No., see figure 16 (sheet 2). Rock-type names assigned in accordance with IUGS system (Le Maitre, 2002) applied to recalculated analyses. $\mathrm{FeO}$, total $\mathrm{Fe}$ calculated as $\mathrm{FeO} ; \mathrm{Mg} \#$, atomic ratio $100 \mathrm{Mg} /\left(\mathrm{Mg}^{2} \mathrm{Fe}^{2+}\right)$ with $\mathrm{Fe}^{2+}$ set to $0.85 \times \mathrm{Fe}^{\text {total }}$. Modal analyses, secondary minerals counted as primary mineral replaced. -, not present. Analyses by D.M. Johnson Cornelius and R.M. Conrey at Peter Hooper GeoAnalytical Laboratory of Washington State University, Pullman, Washington, using methods described in Johnson and others (1999)]

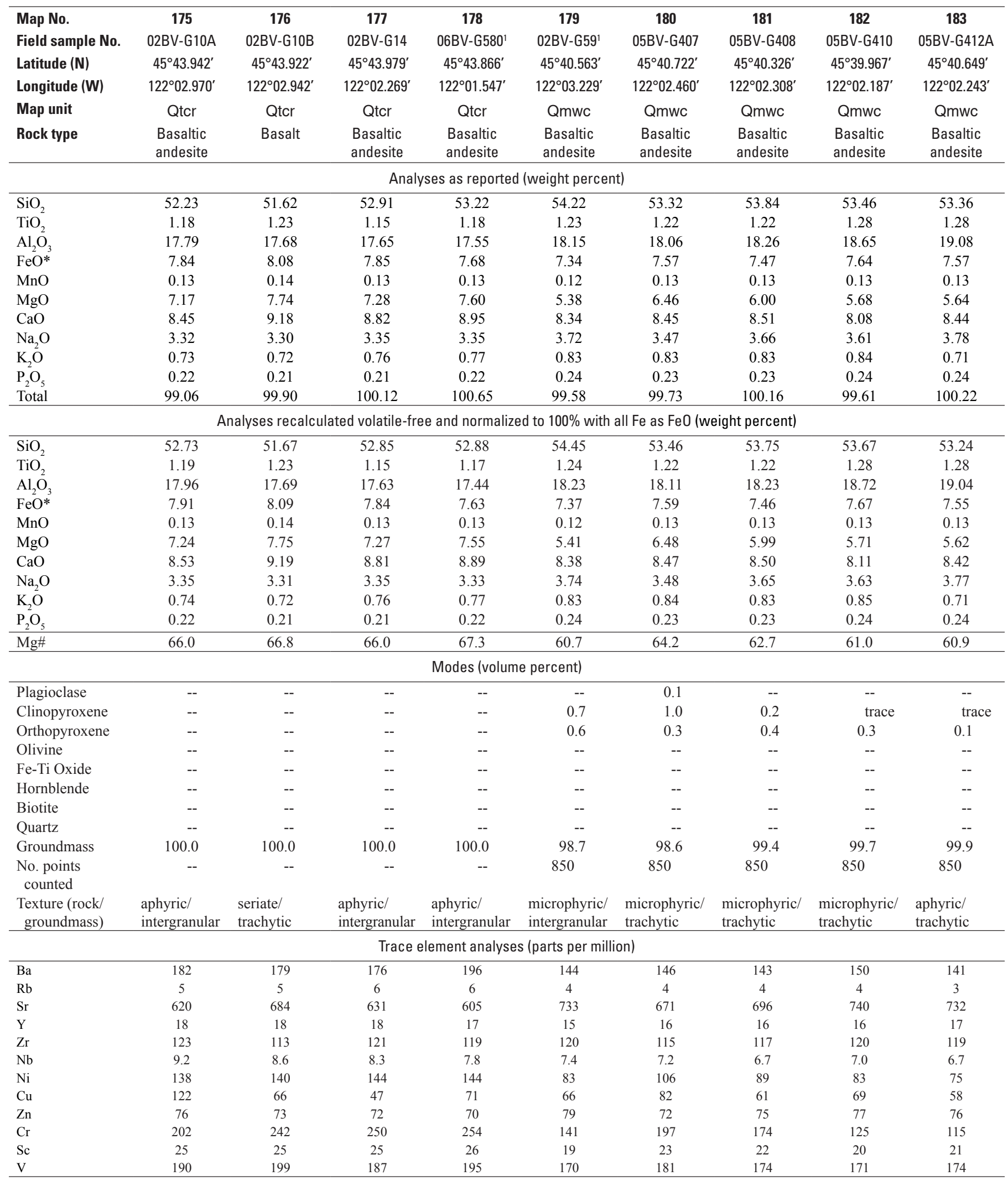

${ }^{1}$ Block in landslide deposit. 
Table 3. Chemical and modal analyses of Quaternary volcanic rocks, Beacon Rock 7.5' quadrangle, Skamania County, Washington.Continued

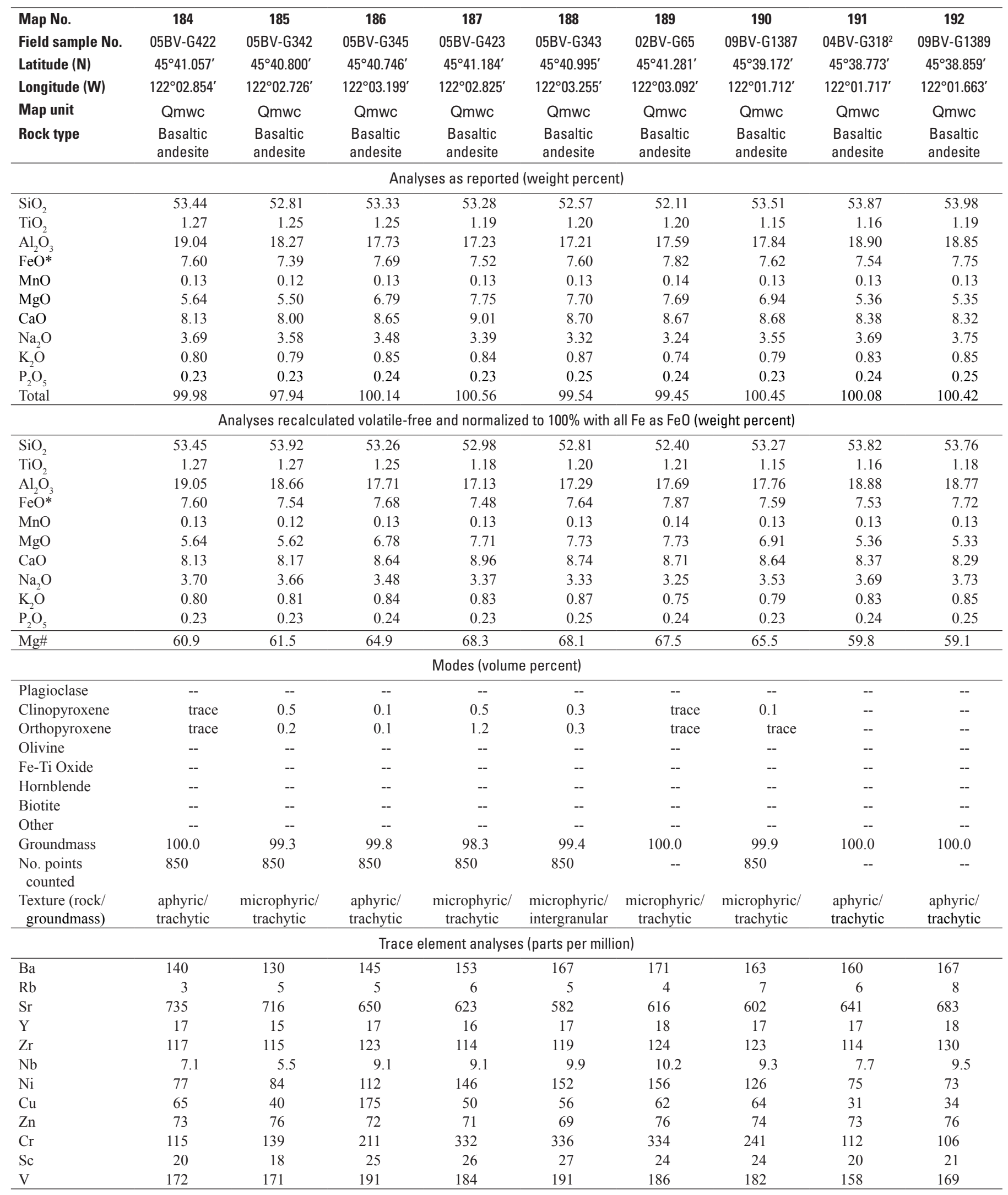

${ }^{2}$ Block in talus deposit. 
Table 3. Chemical and modal analyses of Quaternary volcanic rocks, Beacon Rock 7.5' quadrangle, Skamania County, Washington.Continued

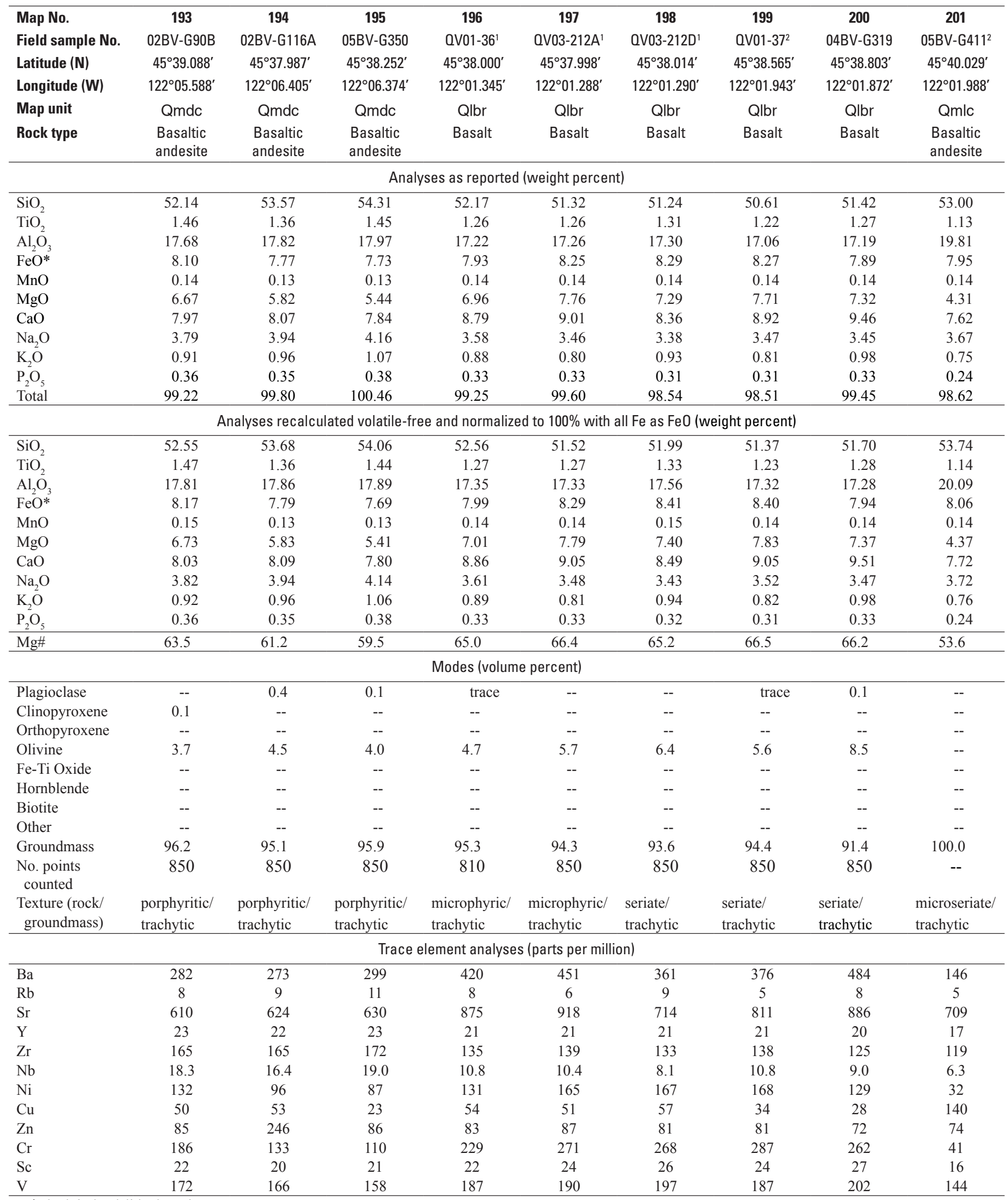

${ }^{1}$ Block in landslide deposit.

${ }^{2}$ Block in talus deposit. 
Table 3. Chemical and modal analyses of Quaternary volcanic rocks, Beacon Rock 7.5' quadrangle, Skamania County, Washington.Continued

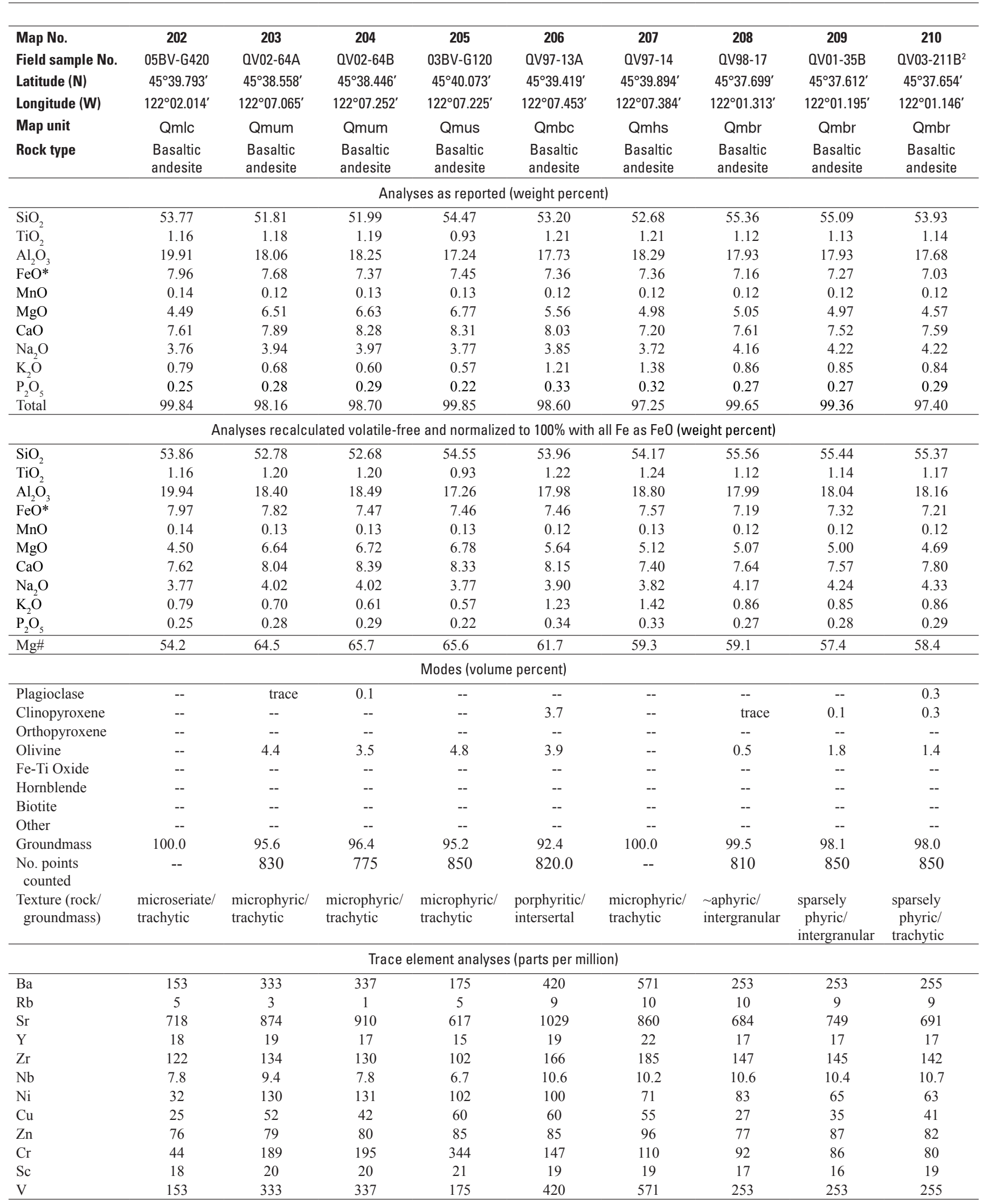

${ }^{2}$ Block in talus deposit. 
Table 3. Chemical and modal analyses of Quaternary volcanic rocks, Beacon Rock 7.5' quadrangle, Skamania County, Washington.Continued

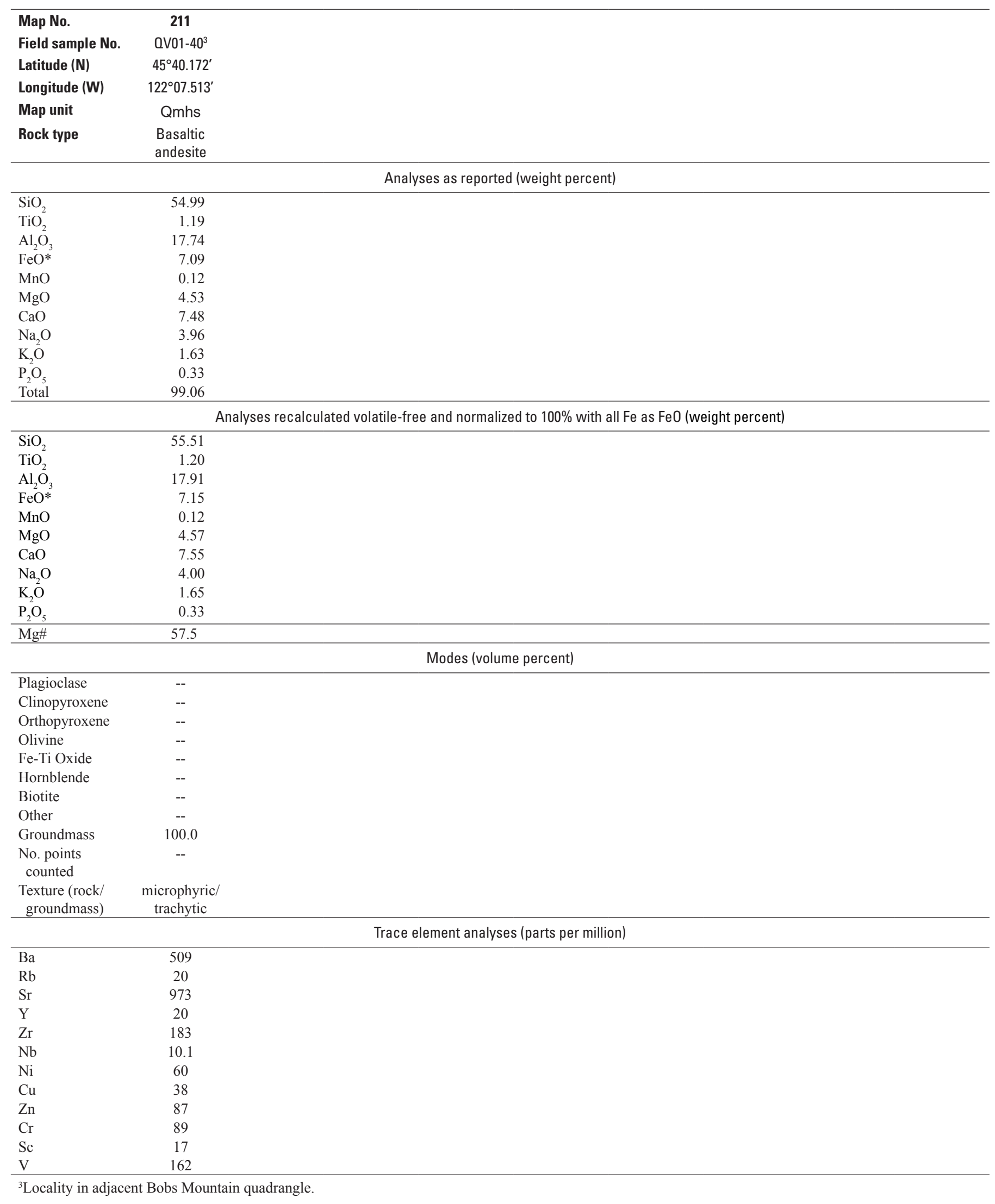


Table 4. Summary of ${ }^{40} \mathrm{Ar} /{ }^{39} \mathrm{Ar}$ incremental-heating age determinations, Beacon Rock 7.5' quadrangle, Skamania County, Washington.

[See figure 17 (sheet 2) for sample locations. Analytical data provided in appendix 1. Ages calculated to a monitor age equivalent to an age of $28.02 \mathrm{Ma}$ for the Fish Canyon Tuff sanidine (FCs) standard (Renne and others, 1998), as described in Fleck and others (2014)]

\begin{tabular}{|c|c|c|c|c|c|c|c|}
\hline \multirow[t]{2}{*}{ Field sample no. } & \multicolumn{2}{|c|}{ Location (NAD 83) } & \multirow[t]{2}{*}{ Map unit } & \multirow[t]{2}{*}{ Rock type } & \multirow[t]{2}{*}{ Material dated } & \multirow[t]{2}{*}{ Age $( \pm 1 \sigma$ error $)$} & \multirow[t]{2}{*}{ Comments } \\
\hline & Latitude (N) & Longitude (W) & & & & & \\
\hline 06BV-G633 & $45^{\circ} 42.627^{\prime}$ & $122^{\circ} 06.590^{\prime}$ & Tba & Andesite & Plagioclase & $25.78 \pm 0.55 \mathrm{Ma}$ & This report \\
\hline 06BV-G700B & $45^{\circ} 43.051^{\prime}$ & $122^{\circ} 04.564^{\prime}$ & Tts & Welded tuff & Plagioclase & $24.30 \pm 0.11 \mathrm{Ma}$ & This report \\
\hline 06BV-G685 & $45^{\circ} 40.913^{\prime}$ & $122^{\circ} 05.914^{\prime}$ & Ttw & Welded tuff & Plagioclase & $24.04 \pm 0.06 \mathrm{Ma}$ & This report \\
\hline 03BV-G122 & $45^{\circ} 40.271^{\prime}$ & $122^{\circ} 07.166^{\prime}$ & Tiah & Andesite & Plagioclase & $<23.14 \pm 0.18 \mathrm{Ma}$ & Maximum age; this report \\
\hline 02BV-G51A & $45^{\circ} 44.699^{\prime}$ & $122^{\circ} 01.869^{\prime}$ & $\mathrm{Tt}$ & Welded tuff & Plagioclase & $22.79 \pm 0.13 \mathrm{Ma}$ & This report \\
\hline 06BV-G650 & $45^{\circ} 44.829^{\prime}$ & $122^{\circ} 04.654^{\prime}$ & Tidcr & Rhyolite & Plagihoclase & $22.60 \pm 0.06 \mathrm{Ma}$ & Tis report \\
\hline 05BV-G437 & $45^{\circ} 41.372^{\prime}$ & $122^{\circ} 00.772^{\prime}$ & Tha & Andesite & Plagioclase & $21.94 \pm 0.06 \mathrm{Ma}$ & This report \\
\hline 02BV-G52A & $45^{\circ} 43.317^{\prime}$ & $122^{\circ} 03.664^{\prime}$ & Thba & Basaltic andesite & Plagioclase & $21.59 \pm 0.31 \mathrm{Ma}$ & This report \\
\hline 04BV-G281A & $45^{\circ} 38.535^{\prime}$ & $122^{\circ} 00.919^{\prime}$ & Teha & Andesite & Plagioclase & $19.50 \pm 0.05 \mathrm{Ma}$ & This report \\
\hline 02BV-G55B & $45^{\circ} 41.376^{\prime}$ & $122^{\circ} 02.999^{\prime}$ & Tecu & Dacite block & Plagioclase & $19.48 \pm 0.04 \mathrm{Ma}$ & This report \\
\hline 06BV-G599 & $45^{\circ} 43.463^{\prime}$ & $122^{\circ} 02.522^{\prime}$ & Tepa & Andesite & Plagioclase & $20.07 \pm 0.03 \mathrm{Ma}$ & This report \\
\hline \multirow[t]{3}{*}{ 05BV-G345 } & $45^{\circ} 40.746^{\prime}$ & $122^{\circ} 03.199^{\prime}$ & Qmwc & Basaltic andesite & Groundmass & $1,068 \pm 8 \mathrm{ka}$ & Fleck and others, 2014 \\
\hline & & & & & & $1,050 \pm 6 \mathrm{ka}$ & This report \\
\hline & & & & & & $1,056 \pm 9 \mathrm{ka}$ & Weighted mean age \\
\hline \multirow[t]{3}{*}{ 02BV-G10A } & $45^{\circ} 43.942^{\prime}$ & $122^{\circ} 02.970^{\prime}$ & Qtcr & Basaltic andesite & Groundmass & $1,065 \pm 6 \mathrm{ka}$ & Fleck and others, 2014 \\
\hline & & & & & & $1,066 \pm 11 \mathrm{ka}$ & This report \\
\hline & & & & & & $1,065 \pm 5 \mathrm{ka}$ & Weighted mean age \\
\hline 05BV-G420 & $45^{\circ} 39.793^{\prime}$ & $122^{\circ} 02.014^{\prime}$ & Qmlc & Basaltic andesite & Groundmass & $1,061 \pm 17 \mathrm{ka}$ & $\begin{array}{l}\text { Corrected from Fleck and } \\
\text { others, } 2014\end{array}$ \\
\hline 02BV-G90B & $45^{\circ} 39.088^{\prime}$ & $122^{\circ} 05.588^{\prime}$ & Qmdc & Basaltic andesite & Groundmass & $821 \pm 24 \mathrm{ka}$ & Fleck and others, 2014 \\
\hline 02BV-G116A & $45^{\circ} 37.987^{\prime}$ & $122^{\circ} 06.405^{\prime}$ & Qmdc & Basaltic andesite & Groundmass & $879 \pm 7 \mathrm{ka}$ & $\begin{array}{l}\text { Preferred age of unit; Fleck } \\
\text { and others, } 2014\end{array}$ \\
\hline QV01-36 & $45^{\circ} 38.000^{\prime}$ & $122^{\circ} 01.345^{\prime}$ & Qlbr & Basaltic andesite & Groundmass & $498 \pm 7 \mathrm{ka}$ & Fleck and others, 2014 \\
\hline QV98-17 & $45^{\circ} 37.700^{\prime}$ & $122^{\circ} 01.313^{\prime}$ & Qmbr & Basaltic andesite & Whole rock & $55.8 \pm 6.1 \mathrm{ka}$ & Fleck and others, 2014 \\
\hline QV98-17 & $45^{\circ} 37.700^{\prime}$ & $122^{\circ} 01.313^{\prime}$ & Qmbr & Basaltic andesite & Whole rock & $84.2 \pm 5.1 \mathrm{ka}$ & $\begin{array}{l}\text { Considered spurious; Fleck } \\
\text { and others, } 2014\end{array}$ \\
\hline QV01-35B & $45^{\circ} 37.612^{\prime}$ & $122^{\circ} 01.195^{\prime}$ & Qmbr & Basaltic andesite & Groundmass & $58.4 \pm 6.4 \mathrm{ka}$ & $\begin{array}{l}\text { Preferred age of unit; Fleck } \\
\text { and others, } 2014\end{array}$ \\
\hline
\end{tabular}


Table 5. Paleomagnetic data for Columbia River Basalt flows and Quaternary volcanic rocks, Beacon Rock 7.5' quadrangle, Skamania County, Washington.

[See figure 18 (sheet 2) for sample locations. $\lambda_{\text {SITE }}$ and $\phi_{\text {SITE }}$ are latitude and west longitude of site (degrees). Strike/Dip, strike and dip of host rock (strike $90^{\circ}$ counterclockwise of dip direction). $I_{\mathcal{C}}, D_{\mathcal{C}}$, paleomagnetic directions corrected for structural tilt. $N / N_{0}$ is number of samples analyzed/number of samples collected. $R$ is vector sum of $N$ unit vectors. $k$ is the concentration parameter (Fisher, 1953) for means calculated using Bingham statistics, $R$ is not calculated. $\alpha 95$, the radius of $95 \%$ confidence (degrees). $\lambda_{P}$ and $\phi_{P}$, latitude and east longitude of virtual geomagnetic pole (degrees) corrected for structural tilt. --, not applicable. Analyses by J.T. Hagstrum, U.S. Geological Survey, Menlo Park, California, using techniques described in Fleck and others (2014). Latitudes and longitudes in North American Datum of 1983 coordinates]

\begin{tabular}{|c|c|c|c|c|c|c|c|c|c|c|c|c|c|}
\hline Fieldsample No & $\begin{array}{l}\text { Laboratory } \\
\text { Sample No. }\end{array}$ & $\begin{array}{l}\text { Map } \\
\text { Unit }\end{array}$ & $\lambda_{\text {SITE }}$ & $\phi$ SITE & $\begin{array}{l}\text { Strike/ } \\
\text { Dip }\end{array}$ & $I_{c}$ & $D_{c}$ & $N / N_{0}$ & $R$ & $k$ & $\alpha_{95}$ & $\lambda_{P}$ & $\phi_{P}$ \\
\hline 02BV-G115B & CB9199 & Tgo & 45.63295 & -122.11005 & $135 / 2$ & 52.0 & 18.5 & $8 / 8$ & 7.9692 & 227 & 3.7 & 70.7 & 3.9 \\
\hline 02BV-G116B & $\mathrm{T} 5065$ & Tgo & 45.63257 & -122.10646 & $135 / 2$ & 68.2 & 18.0 & $7 / 8$ & 5.9685 & 159 & 5.3 & 76.8 & 295.7 \\
\hline 05BV-G429B & $\mathrm{T} 6239$ & Tgo & 45.65935 & -122.01201 & $135 / 2$ & 71.5 & 349.7 & $6 / 8$ & 5.8874 & 44 & 11.3 & 77.7 & 210.5 \\
\hline 05BV-G507 & $\mathrm{T} 6247$ & Tgo & 45.65624 & -122.00977 & $135 / 2$ & 75.9 & 43.2 & $8 / 8$ & 7.8990 & 69 & 6.7 & 60.2 & 276.2 \\
\hline 05BV-G398A & T6311 & Tgo & 45.63022 & -122.10998 & $135 / 2$ & 52.0 & 89.1 & $7 / 8$ & 6.9555 & 135 & 5.2 & 23.2 & 304.3 \\
\hline 04BV-G321 A & -- & Tgo & 45.64830 & -122.02480 & $135 / 2$ & 61.8 & 85.5 & -- & -- & -- & -- & -- & -- \\
\hline $04 \mathrm{BV}-\mathrm{G} 322^{1}$ & -- & Tgo & 45.64704 & -122.02432 & $135 / 2$ & 70.8 & 17.7 & -- & -- & -- & -- & -- & -- \\
\hline QV03-211A & T3374 & Qmbr & 45.62638 & -122.01972 & $0 / 0$ & 72.0 & 27.3 & $9 / 9$ & 8.9597 & 198 & 3.7 & 69.7 & 284.2 \\
\hline QV03-212A ${ }^{2}$ & T3383 & Qlbr & 45.63361 & -122.02183 & $0 / 0$ & 54.7 & 353.6 & $8 / 8$ & 7.9061 & 75 & 6.5 & 78.5 & 85.4 \\
\hline 02BV-G10A & $4 \mathrm{~T} 048$ & Qtcr & 45.73237 & -122.04950 & $0 / 0$ & 46.8 & 19.9 & $7 / 8$ & 6.7788 & 27 & 11.8 & 66.3 & 9.6 \\
\hline 02BV-G90A & $4 \mathrm{~T} 040$ & Qmdc & 45.65117 & -122.09190 & $0 / 0$ & -66.4 & 174.9 & $8 / 8$ & 7.9801 & 352 & 3.0 & 85.3 & 192.7 \\
\hline 04BV-G319 & T6319 & Qmlc & 45.64672 & -122.03120 & $0 / 0$ & 64.9 & 12.6 & $8 / 8$ & 7.9653 & 202 & 3.9 & 81.2 & 315.5 \\
\hline 05BV-G345 & $\mathrm{T} 6217$ & Qmwc & 45.68325 & -122.05425 & $0 / 0$ & 48.5 & 28.1 & $8 / 8$ & 7.9785 & 326 & 3.1 & 62.7 & 354.6 \\
\hline 03BV-G1201 & -- & Qmus & 45.66788 & -122.12042 & $0 / 0$ & 2.7 & 4.8 & -- & -- & -- & -- & -- & -- \\
\hline
\end{tabular}

${ }^{1}$ Oriented hand specimen; considered reliable for polarity only.

${ }^{2}$ Locality is in large slump block; considered reliable for polarity only. 